Andrews University

Digital Commons @ Andrews University

2020

\title{
A Hermeneutic for the Aqedah Test: A Way beyond Jon Levenson's and Terence Fretheim's Models
}

Arlyn Sunshine Drew

Andrews University, drewa@andrews.edu

Follow this and additional works at: https://digitalcommons.andrews.edu/dissertations

Part of the Biblical Studies Commons, and the Religious Thought, Theology and Philosophy of Religion Commons

\section{Recommended Citation}

Drew, Arlyn Sunshine, "A Hermeneutic for the Aqedah Test: A Way beyond Jon Levenson's and Terence Fretheim's Models" (2020). Dissertations. 1719.

https://digitalcommons.andrews.edu/dissertations/1719

https://dx.doi.org/10.32597/dissertations/1719

This Dissertation is brought to you for free and open access by the Graduate Research at Digital Commons @ Andrews University. It has been accepted for inclusion in Dissertations by an authorized administrator of Digital Commons@ Andrews University. For more information, please contact repository@andrews.edu. 
ABSTRACT

A HERMENEUTIC FOR THE AQEDAH TEST: A WAY BEYOND

JON LEVENSON'S AND TERENCE FRETHEIM'S MODELS

by

Arlyn Sunshine Drew

Adviser: Martin Hanna 


\title{
ABSTRACT OF GRADUATE STUDENT RESEARCH \\ Dissertation
}

\author{
Andrews University \\ Seventh-day Adventist Theological Seminary
}

Title: A HERMENEUTIC FOR THE AQEDAH TEST: A WAY BEYOND JON LEVENSON'S AND TERENCE FRETHEIM'S MODELS

Name of researcher: Arlyn Sunshine Drew

Name and degree of faculty adviser: Martin Hanna, Ph.D.

Date completed: March 2020

\section{Problem}

The works of Jon Levenson and Terence Fretheim highlight the problem of determining which interpretations of the biblical worlds of meaning around the text are congruent with the text of the Aqedah (also known as the Sacrifice of Isaac, Genesis 22: 1-19) and which should be disclaimed. A hermeneutical model is needed for Abraham's test that provides a text-based paradigm for sound interpretation of the narrative world (in 
the text), the historical world (behind the text), the theistic world (above the text), the cosmological world (below the text), and the present world (in front of the text).

\section{Method}

Four steps were taken to create and apply a hermeneutical model for understanding the Aqedah test. First, Levenson's and Fretheim's interpretations of the Aqedah were compared to test the usefulness of a tri-level hermeneutic analysis. Second, a tri-level (micro-meso-macro) spiral hermeneutical model was created that integrated the biblical text as the long central axis of the model and related the five biblical worlds of meaning to the text. Third, this model was tested by the Aqedah narrative of Genesis 22:1-19 and a new interpretive hypothesis was perceived. Fourth, the hermeneutical model and the interpretive hypothesis were evaluated.

These four functional tasks were accomplished through six chapters. Chapters one and two introduced the issues and compared the interpretations of two theologians on the Aqedah. Chapters three to five paired sequential construction of the three levels of the hermeneutical model to their Aqedah application. The final chapter evaluated the two products of this study.

\section{Results}

Two conceptual products have emerged from this dissertation project: the Axial Model of hermeneutics and the Covenant Hypothesis for the Aqedah.

The Axial Model embeds the biblical text as the central long axis of a hermeneutical spiral. This text axis emanates the five biblical worlds of meaning (in, 
behind, in front of, above, and below the text) and norms any and all interpretations of those worlds. The spiraling ramp of the Axial Model slices through these worlds of meaning, depicting the features that are accessible for the particular interpreter. The interpreter progresses through the micro, meso and macro levels of hermeneutics (micro: exegetical and biblical hermeneutics, meso: theological and dogmatic hermeneutics, macro: philosophical and metaphysical hermeneutics) in a sequential fashion in order to grasp deep understanding of the text.

Within the Axial Model, the interpretive principle of Sola Scriptura is represented by the central long axis of the biblical text that emanates the biblical worlds of meaning and norms all interpretations of those worlds. Tota Scriptura is embodied in the canonical worlds of meaning behind and in front of the text which clarify and test all interpretations. Prima Scriptura extracts from the worlds of meaning above and below the text the biblical metaphysical framework for interpretation, and Viva Scriptura recognizes the Holy Spirit's transformative work through the fusion of horizons between the interpreter's personal and the text's biblical worlds of meaning. The rolling path of the interpreter on the spiral ramp of the Axial Model integrates three hermeneutical circles (parts to a whole, fusion of horizons, projective-integrative) in achieving comprehensive understanding. This Axial Model was then activated by the Aqedah.

From the micro-hermeneutical level of exegesis, God's final speech (vv. 15-18) in the Aqedah was recognized as an emphatic divine interpretation ("By Myself I have sworn, says the Lord") of Abraham's test response ("because you have done this thing"). Six of the seven Abrahamic covenant revelations were then evoked by God in retrograde 
sequence through covenant themes and blessings. Therefore, the Abrahamic covenant appears to be the divine test norm for evaluating Abraham's test response.

On the meso-hermeneutical level, based on the covenant as the test norm, a logical interpretation was constructed and tested that saw the Aqedah, not as a test requiring mute compliance to destroy the covenant as embodied in Isaac but as a covenant crisis test to be solved by Abraham embodying the covenant. In other words, God's purpose was to test Abraham's covenant identity by eliciting a compassionate response of integrated covenant revelations (Gen 12:1-3, 12:7, 13:14-17, 15, 17, 18, 21:12-13). Had Abraham actualized all seven covenant lessons in his test response, it could have culminated in covenant-driven intercession for Isaac at the altar site, a mediation appealing to God's character of justice and mercy (the covenant lesson of Gen 18). In that scenario, the discovery of God's provided ram was set up to be the climax of Abraham's test as the grace-filled divine test solution ("God will provide") given as the anticipated answer to Abraham's prophetic mediation.

This ideal possibility was not perfectly actualized by Abraham. Hence, the divine interpretation that alluded to only six of the seven covenant lessons was an accurate assessment of Abraham's historic test response. Abraham's faith-filled ("Now I know you fear God") but imperfect response still passed the test because he remained open (hinneni) to mid-test divine correction and did not sacrifice Isaac, but accepted and 
sacrificed the ram as God's provided solution. This theocentric Covenant Hypothesis rests on a linear, non-retracting alignment of God's actions as the Tester in the Aqedah.

Finally, on the macro-hermeneutical level, the Covenant Hypothesis revealed the Aqedah to be a summative (achieving the incorporation of past elements), evaluative (accountable to a standard or norm), diagnostic (revealing any hidden problems or flaw) and formative (assessing for improvement) test of Abraham. Abraham's test obedience is revealed by God's final speech to be an integrative, correctable, healing and dynamic fear of God that exceeds traditional anthropocentric interpretations of Abraham's obedience as a literalistic, uncomprehending, yet hopeful compliance.

\section{Conclusion}

The tri-level Axial Model reveals the Aqedah test narrative holds higher moral consistency and rational complexity than has been traditionally assumed. Most importantly, the Covenant Hypothesis demonstrates that the enigmatic Aqedah text is fully capable of unbinding itself by making sense of its own parts. In conclusion, the Axial Model appears to be a text-normed hermeneutical model that can unearth deeper understanding of biblical texts. 
Andrews University

Seventh-day Adventist Theological Seminary

\title{
A HERMENEUTIC FOR THE AQEDAH TEST: A WAY BEYOND JON LEVENSON'S AND TERENCE FRETHEIM'S MODELS
}

\author{
A Dissertation \\ Presented in Partial Fulfillment \\ of the Requirements for the Degree \\ Doctor of Philosophy
}

by

Arlyn Sunshine Drew

March 2020 
(C) Copyright by Arlyn Sunshine Drew 2020

All Rights Reserved 


\title{
A HERMENEUTIC FOR THE AQEDAH TEST: A WAY BEYOND JON LEVENSON'S AND TERENCE FRETHEIM'S MODELS
}

\author{
A dissertation \\ Presented in partial fulfillment \\ of the requirements for the degree \\ Doctor of Philosophy
}

by

Arlyn Sunshine Drew

APPROVAL BY THE COMMITTEE:

Martin F. Hanna, Faculty Adviser, Associate Professor of Systematic Theology

Jacques R. Doukhan

Professor of Hebrew \& Old Testament Exegesis

John V. G. Matthews

Professor of Educational Foundations

\& Religious Education

Jiří Moskala

Professor of Old Testament Exegesis

\& Theology

J. Richard Middleton

Professor of Biblical Worldview

\& Exegesis, Northeastern Seminary
Director of $\mathrm{PhD} / \mathrm{ThD}$ Program

John W. Reeve

Dean, SDA Theological Seminary

Jiří Moskala

Date approved 
Dedicated to my godly parents Jin Sun Kim and Eun Hi Choi, who self-sacrificed to provide. 


\section{TABLE OF CONTENTS}

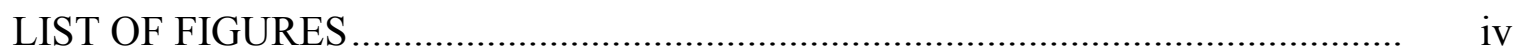

ACKNOWLEDGEMENTS .........................................................................

Chapter

1. TOWARD A HERMENEUTIC FOR THE AQEDAH BEYOND JON LEVENSON'S AND TERENCE FRETHEIM'S MODELS ................ 1

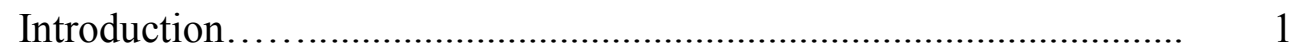

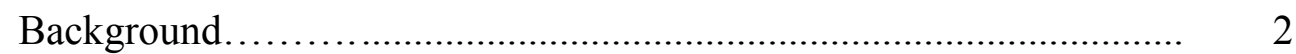

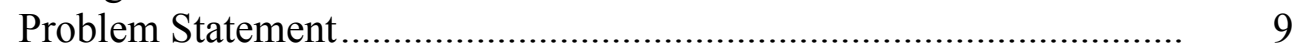

Purpose Statement.......................................................................... 9

Justification Statement ................................................................ 10

Conceptual Framework ......................................................................... 12

Methodology ............................................................................ 18

Scope and Delimitations .............................................................. 20

2. ANALYSIS OF LEVENSON'S AND FRETHEIM'S INTERPRETATIONS

OF THE AQEDAH.......................................................................... 22

Introduction............................................................................ 22

Levenson and the Historical-Critical Method........................................ 28

Biography of Jon Levenson ......................................................... 31

Levenson's Interpretation of the Aqedah ...................................... 32

Analysis of Levenson's Hermeneutics ......................................... 35

Micro-Hermeneutic ............................................................... 35

Meso-Hermeneutic …………………………………........ 39

Macro-Hermeneutic............................................................... 42

Fretheim and the Existential Approach ……………………………….. 45

Biography of Terence Fretheim...................................................... 48

Fretheim's Interpretation of the Aqedah ...................................... 49

Analysis of Fretheim's Hermeneutics............................................. 52

Micro-Hermeneutic ............................................................ 52

Meso-Hermeneutic …….................................................... 54

Macro-Hermeneutic.............................................................. 57

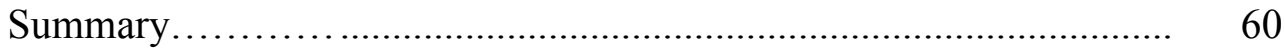

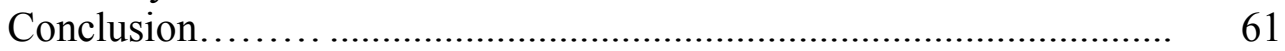

3. A MODEL AND A MICRO-HERMENEUTICAL ANALYSIS FOR THE AQEDAH TEST ................................................. 64 


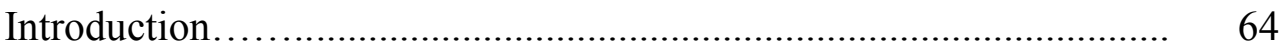

A Model Hermeneutic ......................................................................... 64

Micro-Hermeneutical Analysis of the Aqedah ...................................... $\quad 78$

Morphological-Syntactical Analysis ............................................ $\quad 78$

Narrative Analysis ..................................................................... 99

Exposition....................................................................... 101

Execution................................................................. 111

Resolution................................................................ 125

Conclusion .................................................................... 131

Itinerary ……................................................................. 134

Literary Structural Analysis........................................................ 135

Verbal and Narrative Technique Level .................................... 138

Narrative World Level........................................................... 142

Conceptual Content Level ....................................................... 144

Conclusion ........................................................................... 153

4. A MESO-HERMENEUTIC FOR THE AQEDAH ………………………... 156

Introduction...................................................................... 156

Interpreter in the Model ................................................................ 161

Phases of Interpretation ............................................................... 167

Understanding .......................................................................... 170

Theory and Method of Understanding ................................... 170

Application: Understanding ................................................. 178

Thesis: Theocentric viewpoint ........................................ 178

Alternative thesis: Anthropocentric viewpoint ................ 214

Synthesis: The final form of the Aqedah ........................ 223

Interpretive Hypothesis................................................................ 233

Theory and Method for Interpretive Hypothesis ....................... 233

Application: Covenant Hypothesis Interpretation ..................... 234

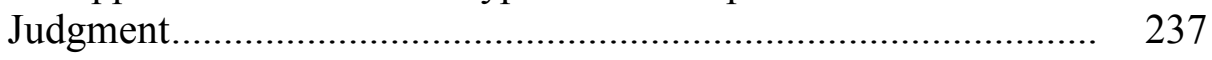

Theory and Method for Judgment .......................................... 237

Tailoring the Hypotheses........................................................ 240

Hypothetico-deductive method: Predictives ………….... 240

Falsification method: Sub-hypotheses and falsifiers........ 241

Rationale for canonical testing ......................................... 245

Application of Hypothetico-Deductive Method ....................... 246

Results of Deductive Method ................................................ 252

Application of Falsification Method ........................................ 252

Results of Falsification Method ............................................. 254

Criticism ....................................................................... 256

Conclusion......................................................................... 263 
5. A MACRO-HERMENEUTIC FOR THE AQEDAH ....................................... 266

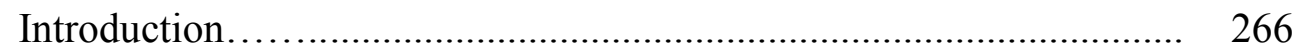

Kierkegaard and Derrida on the Aqedah .......................................... 268

Kierkegaard's Four Paradoxes................................................... 268

Derrida's Double Secret ............................................................ $\quad 280$

Model Cores and Macro-hermeneutical Methodology .......................... 296

Model Cores ......................................................................... 296

Macro-Hermeneutical Methodology .......................................... 304

Ontology of the Aqedah Event ........................................................... 307

Ontology of God ................................................................... 311

"After these things" ................................................................ 311

"God tested Abraham" ........................................................... 316

"and [God] said to him, "Abraham." "...................................... 318

Ontology of Abraham .............................................................. 318

"After these things" ............................................................... 318

"God tested Abraham" ............................................................. 321

"and [God] said to him, "Abraham." "...................................... 323

Epistemology of the Aqedah.............................................................. 324

Epistemology of the Beginning Verse .......................................... 324

"After these things" ............................................................... 324

"God tested Abraham" ............................................................ 326

"and [God] said to him, "Abraham." "...................................... 327

God as the Hermeneutical Tester............................................... 328

Abraham as the Hermeneutical Testee ........................................... 336

Axiology of the Aqedah................................................................. 342

Axiology of the Beginning Verse ............................................... 342

"After these things" ................................................................ 342

"God tested Abraham" ........................................................... 343

"and [God] said to him, "Abraham." "........................................ 345

Modified Virtue Ethics ................................................................... 345

Aesthetics of Lek-lekha ............................................................ 351

Conclusion........................................................................ 356

6. ASSESSMENT AND RECOMMENDATIONS _.......................................... 358

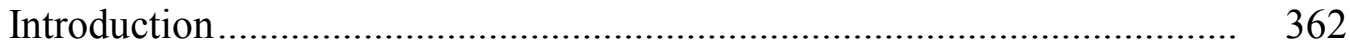

Assessment of the Axial Model .............................................................. 363

Assessment of the Covenant Hypothesis ................................................... 365

Progress through the Axial Model ............................................................ 369

Recommendations, ,",, ........................................................................ 370

CITED BIBLIOGRAPHY ………….......................................................... 373 


\section{LIST OF FIGURES}

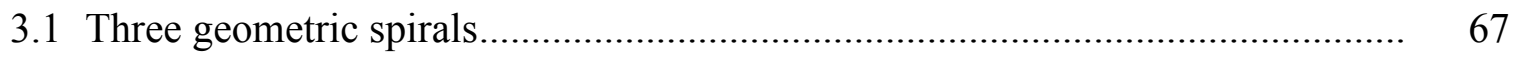

3.2 Biblical text as long axis $(Z)$ of Axial Model = Sola Scriptura ......................... 68

3.3 Three hermeneutical levels of the Axial Model ............................................... 70

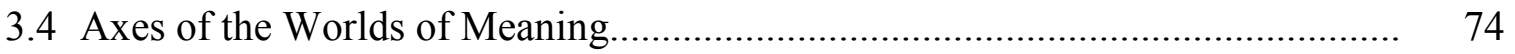

3.5 Chiastic structure of the Aqedah.............................................................. 145

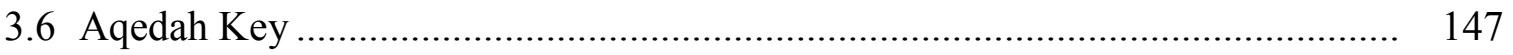

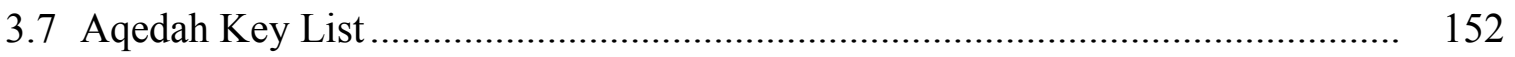

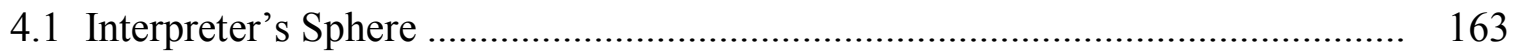

4.2 Spiral circuit of interpreter and Viva Scriptura ......................................... 165

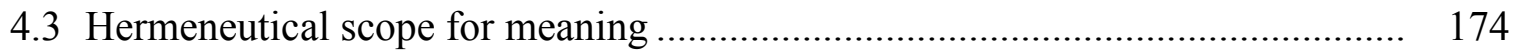

4.4 Locus of Relation targeted by the phrase: "not withhold" .............................. 207

4.5 The Covenant Hypothesis: Human and Divine Viewpoints in the Aqedah.......... 224

4.6 Present literary structure reveals asymmetry ......................................... 226

4.7 Reconstruction of a symmetrical literary structure .................................... 229

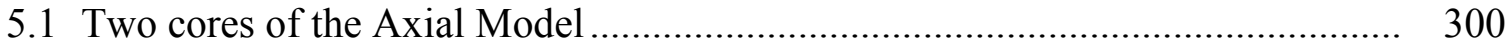




\section{ACKNOWLEDGMENTS}

I would like to express profound gratitude to my primary advisor, Dr. Martin Hanna, who placed great faith in me by envisioning a dissertation project of this scope and allowing me to retain my interest in the Sacrifice of Isaac. I also want to thank Dr. Darius Jankiewicz for providing a safe haven in my department. Much of this dissertation stands on the shoulders of Dr. Jacques Doukhan's work on the Aqedah and his presence on my committee has been invaluable. Dr. John Matthew's meticulous corrections, warm encouragement and theological probing throughout this journey means more than I can say. In addition, I am indebted to Dr. Richard Middleton and Dr. Jiri Moskala who graciously gifted their expertise and time to reading and examining this work to improve it.

On the personal front, the unstinting financial, emotional and mental support of Dr. Kevin Drew, my husband, was priceless and the boundless love from my precious children, Alyson, Cassy, Grant, Delilah, Luke and Zoe, always kept before me what was at stake in correctly understanding the God of Abraham in this harrowing tale. Finally, and most importantly, I give sincere and wholehearted thanks to my Lord, who provided unexpected new insights from His own words. Without such gracious divine gifts, this dissertation would have been an obligation instead of the most exciting and arduous adventure of the last three years. God has provided and I am deeply grateful. 


\section{CHAPTER 1}

\section{TOWARD A HERMENEUTIC FOR THE AQEDAH BEYOND JON LEVENSON'S AND TERENCE FRETHEIM'S MODELS}

\section{Introduction}

One of the most famous and controversial narratives in the Bible is the Aqedah or the Binding of Isaac. ${ }^{1}$ This enigmatic and evocatively styled test ${ }^{2}$ is constituted by three dialogues in a literary chiastic structure. ${ }^{3}$ In the first exchange, Abraham is commanded by God to sacrifice Isaac, the covenant bearer, as a burnt offering (Gen 22:1-2). ${ }^{4}$ The

\footnotetext{
${ }^{1}$ The biblical narrative is called Sacrifice of Isaac in Christianity and referred to as the Aqedah in Judaism. The term Aqedah refers to the act of binding Isaac in Genesis 22:1-19. A more narrow use of the term Aqedah is recommended by Phillip Davies and Bruce D. Chilton who propose it be reserved for "the haggadic presentation of the vicariously atoning sacrifice of Isaac in which he is said, e.g., to have shed his blood freely and/or to have been reduced to ashes." This suggestion is because this term relates to a mishnaic usage describing the tying of the Tamid Lamb, a context of cultic and sacrificial theology. Philip R. Davies and Bruce D. Chilton, "The Aqedah: A Revised Tradition History," The Catholic Biblical Quarterly 40, no. 4 (1978): 514-546. See also Shalom Spiegel, The Last Trial, trans. Judah Goldin (New York: Pantheon Books, 1967), xxiii-xxiv.

${ }^{2}$ Erich Auerbach famously described the Hebrew literary style of the Aqedah where "time and place are undefined and call for interpretation; thoughts and feelings remain unexpressed, are only suggested by the silence and the fragmentary speeches; the whole, permeated with the most unrelieved suspense and directed toward a single goal (and to that extent far more of a unity), remains mysterious and 'fraught with background'... The Scripture stories do not, like Homer's, court our favor, they do not flatter us that they may please us and enchant us - they seek to subject us, and if we refuse to be subjected we are rebels." Erich Auerbach, Mimesis: The Representation of Reality in Western Literature (Princeton, NJ: Princeton University Press, 1953), 9, 12.

${ }^{3}$ Jacques Doukhan, "The Center of the Aqedah: A Study of the Literary Structure of Genesis 22:119," Andrews University Seminary Studies 31, no. 1 (Spring 1993): 17-28.

${ }^{4}$ All biblical verses referenced in this dissertation will be from the Revised Standard Version
} 
second dialogue is the center of the chiastic structure where the father and son discuss the need for a sacrificial lamb (Gen 22:7-8). In the last dialogue Abraham is forbidden to consummate his act of obedience (Gen 22:11-12) and is provided with a ram. After Abraham sacrifices the ram in place of Isaac, God commends Abraham for obeying the His voice (Gen 22:16-18). This narrative has elicited a multiplicity of interpretations on the complex meaning of Abraham's greatest and final test. ${ }^{5}$

\section{Background}

Historically, this narrative has been interpreted with overlapping but different emphases by the three religious traditions that reference Abraham as their spiritual father. Because Abraham obeyed both commands and was commended for "the fear of God" (Gen 22:12) and for “obeying my [God's] voice" (Gen 22:18), many Jews have accepted the virtue of meticulous obedience as the main point of the test without excluding Abraham's faith in God. ${ }^{6}$ On the other hand, because God thwarted Abraham from fully

except for chapter three, which will use Robert Alter's translation of Genesis for its narrative faithfulness to the style of the original Hebrew.

${ }^{5}$ JoAnn Davidson, with many other Christian theologians, suggests that in addition to the testing of Abraham, the Aqedah offered prophetic typological lessons from the sacrifice of the ram that pointed to the Messiah. Abraham's personal suffering prefigured and impressed upon Abraham the love of God the Father who later gave up his Son for mankind (Rom 8:32). Jo Ann Davidson, "Abraham, Akedah and Atonement," in Creation, Life, and Hope: Essays in Honor of Jacques Doukhan, ed. Jiri Moskala (Berrien Springs, MI: The Old Testament Department, Seventh-day Adventist Theological Seminary, Andrews University, 2000), 63-64.

${ }^{6}$ Jon Levenson says, “Abraham's willingness to heed the frightful command may or may not demonstrate faith in the promise that is invested in Isaac, but it surely and abundantly demonstrates his putting obedience to God ahead of every possible competitor." Jon D. Levenson, The Death and Resurrection of the Beloved Son: The Transformation of Child Sacrifice in Judaism and Christianity (New Haven, CT: Yale University Press, 1993), 126. Jacob Licht concurs, "The deeply significant theme of the story is that Abraham withstood the cruel last test of obedience by carrying out without murmur God's command to sacrifice Isaac." Jacob Licht, Storytelling in the Bible (Jerusalem: Magnes Press, 1986), 115- 
consummating his obedience (Gen 22:12), Christians tend to focus on Abraham's faith, while acknowledging that it was his actions or works (Gen 22:16) which demonstrated this inner state. ${ }^{7}$ Most Muslims accept the overarching virtue of submission as the primary religious meaning of the narrative. ${ }^{8}$ The interactive dialogue that has historically existed between these three religions on the meaning of the Aqedah has contributed to the richness and depth of their religious interpretations. ${ }^{9}$

In addition to these religious traditions, more recent hermeneutical approaches have contributed various interpretations of the Aqedah test. One of them, the historical-

116. See also Louis A. Berman, The Akedah: The Binding of Isaac (Northvale, NJ: Jason Aronson, 1997), 115 .

7 The Christian New Testament praises Abraham's actions as exemplary in demonstrating his faith: "By faith Abraham, when he was tested, offered up Isaac, and he who had received the promises was ready to offer up his only son of whom it was said 'Through Isaac shall your descendants be named.' He considered that God was able to raise men even from the dead; hence, figuratively speaking, he did receive him back." (Heb 11:17). See also Jon Balserak, "Luther, Calvin and Musculus on Abraham's Trial: Exegetical History and the Transformation of Genesis 22," Reformation and Renaissance Review 6, no. 3 (2004): 361-373; Ellen G. White, The Story of Patriarchs and Prophets, The Conflict of the Ages Series, vol. 1 (Mountain View, CA: Pacific Press, 1958), 154; Gerhard von Rad, Genesis: A Commentary (Philadelphia, PA: Westminster Press, 1972), 244; John Calvin, Commentaries on the First Book of Moses Called Genesis, trans. John King, vol. 1 (Grand Rapids, MI: Eerdmans, 1948), 560-561; Augustine through the Ages: An Encyclopedia (Grand Rapids, MI: Eerdmans, 1999), s.v. "Abraham."

${ }^{8}$ The Quran records the turning point of the narrative: "When they had both submitted to God and he had laid his son down on the side of his face, We called out to him, 'Abraham, you have fulfilled the dream.' This is how We reward those who do good-It was a test [to prove their true characters]-We ransomed his son with a momentous sacrifice and we let him be praised by succeeding generations, 'Peace be upon Abraham!' This is how we reward those who do good: truly he was one of Our faithful servants." Sura 37:103-111 as translated in The Qur'an: English Translation with Parrallel Arabic Text, trans. Abdel Haleem (Oxford, UK: Oxford University Press, 2010).

${ }^{9}$ For an engrossing discussion about the historical dialogue and cross pollination of ideas between the Jewish, Christian and Moslem traditions on the Aqedah, see Jacques Doukhan, "The Aqedah at the Crossroads: Its Significance in the Jewish-Christian-Muslim Dialogue," Andrews University Seminary Studies 32, nos. 1-2 (1994): 20-40. See also Yvonne Sherwood, "Binding-Unbinding: Divided Responses of Judaism, Christianity, and Islam to the 'Sacrifice' of Abraham's Beloved Son," Journal of the American Academy of Religion 72, no. 4 (2004): 821-861. While acknowledging the debt to Moslem scholars that 
critical method, ${ }^{10}$ which has profoundly influenced biblical interpretation for much of the twentieth century, aimed at a scientific diachronic study of the text. The historical search for the original text and the history behind it may put into question the text in its present actuality. ${ }^{11}$ For example, the historical-critical method as used by Omri Boehm interpreted Abraham's actions in response to God's test as ethical disobedience. ${ }^{12}$ Boehm bracketed out the angelic messages as later redactions of the text, leaving a storyline where Abraham in ethical defiance disobeyed God by offering the ram instead of Isaac. ${ }^{13}$ Because no divine directive was given regarding the ram substitution, Boehm suggests that it is Abraham's demonstration of reactionary morality that characterizes the chosen people and saves Isaac. ${ }^{14}$

In sharp contrast to this interpretation of ethical disobedience is an existential philosophical interpretation of the test by Søren Kierkegaard who calls Abraham the

Christian theology on the Aqedah owes, this study will not pursue the Moslem tradition due to language limitations.

10 The historical-critical method is a diachronic study of the biblical text that refers to the historical phenomena of the linguistic features of the text. For the strengths and weaknesses of the historical-critical method see Bruce Corley, Steve W. Lemke, and Grant I. Lovejoy, eds., Biblical Hermeneutics: A Comprehensive Introduction to Interpreting Scripture, $2^{\text {nd }}$ ed. (Nashville, TN: Broadman and Holman, 2002), 377; Jon D. Levenson, The Hebrew Bible, the Old Testament, and Historical Criticism (Louisville, KY: Westminster John Knox Press, 1993); and Gerhard Maier, Biblical Hermeneutics (Wheaton, IL: Crossway Books, 1994), 247-307.

${ }^{11}$ Joseph A. Fitzmyer, The Biblical Commission's Document "The Interpretation of the Bible in the Church": Text and Commentary (Rome, ITL: Editrice Pontificio Istituto Biblico, 1995), 26-44.

${ }^{12}$ Omri Boehm, The Binding of Isaac: A Religious Model of Disobedience (New York, NY: T\&T Clark International, 2007).

${ }^{13}$ Boehm, The Binding of Isaac, 23-33.

${ }^{14}$ According to Boehm, "In contrast to the pagan myth, the monotheistic people exist, not because the father of monotheism sacrificed his 'beloved son,' but because he refused to do so. Indeed, the Binding 
"Knight of Faith."15 The existential approach to the Bible focuses on the reader, in front of the text, as the subject who comes to a personal understanding of reality and internalizes the indirect meaning of the Bible or word of God as his or her personal authority. ${ }^{16}$ According to Kierkegaard, true religion requires direct individual accountability to God. In Kierkegaard's interpretation, Abraham passes God's test by relinquishing Isaac in a "teleological suspension of the ethical." ${ }^{17}$ In other words, all ethical and universal norms are transcendently bypassed by a true fear of God. ${ }^{18}$

Two prominent and contemporary scholars, Jon Levenson and Terence Fretheim, demonstrate additional hermeneutical approaches that continue the trajectories of

does not so much test Abraham as present him as a model of faith." Boehm, The Binding of Isaac, 123.

${ }^{15}$ Søren Kierkegaard, Fear and Trembling (London, UK: Penguin Group, 1985), 99. Much has been written about Kierkegaard's interpretation of the Aqedah. See Jerome Gellman, Abraham! Abraham! Kierkegaard and the Hasidim on the Binding of Isaac (Burlington, VT: Ashgate Publishing, 2003); Edward F. Mooney, "Abraham and Dilemma: Kierkegaard's Theological Suspension of the Ethical Revisited," International Journal for Philosophy of Religion 19, no. 2 (1986): 23-41; R. Zachary Manis, "Kierkegaard and Evans on the Problem of Abraham," Journal of Religious Ethics 39, no. 3 (2011): 474-492; Brian Stiltner, "Who Can Understand Abraham? The Relation of God and Morality in Kierkegaard and Aquinas," Journal of Religious Ethics 21, no. 2 (1993): 221-245.

${ }^{16}$ Existential hermeneutics does not characterize a specific method but is rather an "existential analytic of being" utilizing a phenomenological approach to scripture or literature. The role of history and language in existential hermeneutics has become more vital to extracting the meaning of the text but this method remains centered on the reader as the text's final interpreter and focus. J. C. Robinson, "Existential Hermeneutics," Dictionary of Biblical Criticism and Interpretation (2007), 105-106.

${ }^{17}$ Kierkegaard, Fear and Trembling, 85.

${ }^{18}$ Kierkegaard believes it is Abraham's faith-filled fear of God-defined as his unreserved responsiveness to God's command - that is being tested. Kierkegaard, Fear and Trembling, 144. Jerome Gellman believes Kierkegaard's singular focus on the connection between God and man that subjugates everyone and everything else was a reaction of existential self-actualization against the Hegelian ideal of Kierkegaard's day where self-actualization occurs only within "social structures that embody the ethical." Gellman, Abraham! Abraham!, 32. But Georg Friedrich Hegel did not see Abraham as a Hegelian hero but as an anti-hero. For Hegel, the Aqedah was the epitome of Abraham's consistent detachment from others: "Even this love [for his son] he once wished to destroy; and his heart was quieted only through the certainty of the feeling that this love was not so strong as to render him unable to slay his beloved son with his own 
historical and existential approaches to interpreting the Aqedah test. The first trajectory is evident in Jon Levenson's book, The Death and Resurrection of the Beloved Son, which illuminates the hermeneutical benefits of studying the socio-historical background behind the Aqedah in search of the world behind the text. ${ }^{19}$ Levenson traces the historical transformation of the religious impulse to donate the precious firstborn male to a deity and concludes that the Aqedah was part of a historical continuum that eventually sublimated the ritual of child sacrifice into a "sublime religious paradigm" 20 in front of

hand." Georg Wilhelm Friedrich Hegel, Early Theological Writings, trans. T. M. Knox (Chicago, IL: University of Chicago Press, 1948), 187. Both Kierkegaard and Hegel interpreted the meaning of the Aqedah test as human relinquishment and detachment. This is a common interpretation. See Jo Milgrom, The Binding of Isaac, the Akedah: A Primary Symbol in Jewish Thought and Art, ed. Duane L. Christensen, Doctoral Dissertations of Graduate Theological Union (Berkeley: BIBAL Press, 1988), 29, 60; Phyllis Trible, "Genesis 22: The Sacrifice of Sarah," in "Not in Heaven": Coherence and Complexity in Biblical Narrative, eds. J. Rosenblatt and J. Sitterson (Bloomington, IN: Indiana University Press, 1991), 170-191; Paul Borgman, Genesis: The Story We Haven't Heard (Downers Grove, IL: InterVarsity Press, 2001), 101. Gerhard von Rad takes the theme of relinquishment even further, "It [the Aqedah] concerns something much more frightful than child sacrifice. It has to do with a road out into Godforsakenness." Von Rad, Genesis, 244.

19 "There is no such thing as the text in and of itself or the text as a world unto itself, and no possibility of standing before the text without also, in some measure, getting behind it. The question is not whether we make historical judgments; the question can only be whether we do so poorly or well." Jon Levenson, The Hebrew Bible, the Old Testament, and Historical Criticism, 110. Carmody explains what lies behind the text: "The world behind the text refers to the world that generated the text. Primarily this means the author, who had a reason and a purpose for writing the text.... The social, historical, religious world in which the author lived is also an important feature of the world behind the text. . . Another aspect of the world behind the text is the language of the time." Timothy R. Carmody, Reading the Bible: A Study Guide (Mahwah, NJ: Paulist Press, 2004), 11.

\footnotetext{
${ }^{20}$ Levenson, Death and Resurrection, $\mathrm{x}$.
} 
the text that has been embraced and applied by Christianity to the crucifixion of Jesus

Christ. $^{21}$

Terence Fretheim is aligned with the existential trajectory that centers the interpretive focus of the Aqedah test on the present reader and his or her worldview. In his book, Abraham: Trials of Family and Faith, Fretheim engages and challenges both modern life issues and traditional theological assumptions of God $^{22}$ through the Aqedah test. To the extent that he focuses on the reader's response, Fretheim situates the meaning of the Aqedah test in the reader's world in front of the text. ${ }^{23}$ To the extent that he focuses

21 Levenson, Death and Resurrection, 200-219. Another interpretation for the historical social background of sacrifice is given by René Girard who suggests that 'mimetic' (imitative) desire leads to rivalry and aggression, which were sublimated by many communities into the sacrifice of a scapegoat. This act served to restore peace and the scapegoat was then venerated as an object of worship by the community for its efficacy in restoring stability. Rene Girard, Violence and the Sacred (New York, NY: Continuum, 2005), 4-7.

22 Terence Fretheim does not claim to be an open theist, but his hermeneutical method of interpreting biblical metaphors has been used by open theists to challenge classical theistic propositions. For instance, in contrast to the classical theistic belief that God's omniscience means that God has no lack of knowledge and does not learn or change, Fretheim asserts, "While God no doubt knew what was likely to happen given the intimate knowledge of Abraham, God in fact gains new knowledge with respect to Abraham (as does the reader). This is a hard, even offensive word about God for many, and readers are advised not to follow their instincts and seek to interpret their way out of it." Terence E. Fretheim, Abraham: Trials of Family and Faith (Columbia, SC: University of South Carolina, 2007), 136. Jerry Harmon discusses how Terence Fretheim's hermeneutics have been adopted by open theists in his dissertation, "Exodus 34:6-7: A Hermeneutical Key in the Open Theism Debate" (PhD dissertation, MidAmerica Baptist Theological Seminary, 2006).

23 "It is possible to separate out three loci of meaning, or to find in the discourse three different players who contribute to the meaning of the text. These are the author, the text, and the reader. . . The three players or three loci of meaning are: the world behind the text, the world of the text, and the world in front of the text." Carmody, Reading the Bible, 10; "The [reader's] imagination is involved primarily in the hermeneutical task of explicating the referent. . . The referent is the meaning 'in front of' the text, 'that way of perceiving reality, that mode of being-in-the-world which the text opens up for the intelligent reader." Edgar V. McKnight, Post-Modern Use of the Bible: The Emergence of Reader-Oriented Criticism (Nashville, TN: Abingdon Press, 1990), 106. Acknowledgment of inherent biases and contemporary assumptions that the reader brings to the text may actually enhance the rigor of a study of the text by allowing the reader to read and interpret "with greater awareness and self-consciousness." Robert M. Fowler, Let the Reader Understand: Reader-Response Criticism and the Gospel of Mark (New York, NY: 
on the reader's discovery of insights about the nature of God, Fretheim situates that meaning in the metaphysical world above the text. ${ }^{24}$ The anthropological aspect is included in the cosmological presuppositions of both Levenson and Fretheim which are accepted implicitly as the essence of our natural world below the text. ${ }^{25}$

Both scholars engage in the literary analysis of the text to bring out the narrative world within the text. This relationship of characters and events to each other in a presumed temporal world can be referred to as the world of meaning in the text. To sum up, a hermeneutical model is needed that is anchored in the text as the controlling norm

Bloomsbury Academic, 1991), 81.

24 "What is 'above' the text? If the text is semantic process, encoded in the lexicogrammatical system, what is it the encoding of in its turn? What is 'above' depends on one's perspective, on the nature of the enquiry and the ideology of the inquirer." Macmillian A. K. Halliday, Linguistic Studies of Text and Discourse, ed. Jonathan Webster, Collected Works of M. A. K. Halliday (New York, NY: Continuum, 2002), 48. Since for the believing theologian the ultimate reality of the text and sole source of biblical revelation is God, the phrase above the text in biblical studies refers to theocentric theology or metaphysical assumptions about God. Thus, the text functions as the normative channel for perceiving the wider range of significance regarding the divine Author of the Bible, which may exceed the original intention of the human writer and the intended original audience. Even if there is not "total identity between the meaning of the divine and human authors, there is total identity (by divine choice) between God's words and theirs."

Ramesh P. Richard, "Methodological Proposals for Scripture Relevance, Part 2: Levels of Biblical Meaning," Bibliotheca Sacra 143, (April 1986): 125.

${ }^{25}$ Below the text is an uncommon term and I was unable to find prior reference to it in the literature surveyed. Yet, if above the text refers to theocentric theology and metaphysical assumptions about God then underlying metaphysical assumptions about the essential nature of the cosmos, including man, would be what is designated by the phrase below the text. While both the author and the reader may hold different assumptions about the nature of the cosmos, ultimately the biblical text must also function here as the norm for believers in revealing the biblical understanding of the world and human nature. 
in order to faithfully illuminate the interpretation of the multiple worlds of meanings of the Aqedah. ${ }^{26}$

\section{Problem Statement}

The works of Levenson and Fretheim highlight the problem of determining which interpretations of the worlds around the text are congruent with the text of the Aqedah and which should be disclaimed. A hermeneutical model is needed for Abraham's test that provides a text-based paradigm for sound interpretation of the narrative world (in the text), the historical world (behind the text), the theistic world (above the text), the cosmological world (below the text), and the present world (in front of the text). ${ }^{27}$

\section{Purpose Statement}

The purpose of my dissertation is to respond to the works of Jon Levenson and Terrence Fretheim by forming and applying a hermeneutical model that institutes the text of the Aqedah as the norm for a comprehensive interpretive paradigm. The goal of this model is to elucidate the test of the Aqedah and to illuminate its multiple worlds of

\footnotetext{
${ }^{26}$ One example of the role of the text functioning as a norm over multiple possibilities of meaning is demonstrated by Ricoeur's hermeneutical use of plenitude and fittingness. "The principle of plenitude is especially operative at the first stage as the rule that opens up the text to all its possible connotations, allowing the text to mean all that it can mean; the principle of fittingness, on the other hand, restricts the range of connotations in the text by an appeal to the congruence between these connotations and the text's subject matter." Ricoeur cited by Mark I. Wallace, The Second Naiveté: Barth, Ricoeur, and the New Yale Theology, $2^{\text {nd }}$ ed. Studies in American Biblical Hermeneutics, vol. 6 (Macon, GA: Mercer University Press, 1990), 65.

${ }^{27}$ Beardsley points out that only by positing a rational methodological control, i.e., a "nonrelativistic logic for explication," to test subjective conjectures, can there be any credible criteria of meaning. For Beardsley, the phrase "nonrelativistic logic" refers to a hermeneutical method that must be structured and substantiated. Monroe C. Beardsley, Aesthetics: Problems in the Philosophy of Criticism $2^{\text {nd }}$ ed. (Indianapolis, IN: Hackett Publishing, 1981), 134.
} 
meaning which are figuratively described as in the text, behind the text, above the text, below the text and in front of the text.

\section{Justification Statement}

The rationale for a text-defined hermeneutical paradigm is to avoid the problem of forced eisegesis and unbalanced exegesis. Without the text functioning as the norm, multiple considerations outside the text may dominate, impose onto or distort the meaning of the narrative. For instance, when Levenson concludes, "The aqedah, in short, tests whether Abraham is prepared to surrender his son to the God who gave him,"28 Levenson's belief that the ancient urge for sacrificial "donation" of the firstborn to a deity as constituting the historical-social background of the text, directs Levenson's hermeneutic to focus on Abraham's willingness to donate his son through death. ${ }^{29}$

On the other hand, Fretheim holds the presupposition that God "lacks a certain kind of knowledge, ${ }^{30}$ thus, a test was necessary in order to fulfill a divine need to know. Fretheim points out that in the Aqedah "the only one said to learn anything from the test is God." 31 Because of Levenson's and Fretheim's presuppositions, the test of the Aqedah is interpreted in different ways that may or may not demonstrate coherence with each other or with the text.

\footnotetext{
${ }^{28}$ Levenson, Death and Resurrection, 126.

${ }^{29}$ Levenson, Death and Resurrection, ix, 3, 4, 8.

${ }^{30}$ Fretheim, Abraham, 136.

${ }^{31}$ Fretheim, Abraham, 36.
} 
It is widely acknowledged, and I concur, that the text of the Aqedah offers its own paradigm of divine testing as an anchoring hermeneutic in the introductory verse; "After these things, God tested Abraham" (Gen 22:1). Fretheim acknowledges, "This [test] theme is central to understanding all that follows. ${ }^{{ }^{32}}$ Levenson concurs with Fretheim and calls this event "YHWH's greatest test of his servant Abraham." ${ }_{33}$ However, the general recognition of this narrative as a divine test has not led to consensus on the meaning. Most often, the interpretive focus of the test has been anthropological: What in Abraham is being tested? Or why does Abraham need to be tested? This anthropocentric focus has elicited various responses as the Jewish, Christian and Muslim and other hermeneutical interpretations demonstrate. Redirecting the focus in the opposite direction, that is, theocentrically, the question becomes: What is the divine intent of this test? Or more textually articulated, what is the intentional direction of this test?

Ascertaining the divine intentionality of Abraham's test remains a challenge due to perceived tensions in the test such as (1) God's test command to immolate Isaac appears to nullify all previous commands and covenant promises, (2) the two divine commands (to offer him up and to not do anything to him) concerning Isaac appear to contradict each other, (3) the apex of the chiasm echoes Abraham's response toward his human son—not God, and (4) God clearly praises Abraham for obeying the voice of the

\footnotetext{
${ }^{32}$ Fretheim, Abraham,132.

${ }^{33}$ Levenson, Death and Resurrection, 12.
} 
Lord yet the actual solution to the test and the final obedient act of sacrificing the ram in the place of Isaac does not match a verbal substitutionary command in the text.

A close application of a text-based hermeneutical paradigm of divine testing to this narrative, through the historical grammatical method that recognizes the multiple worlds of meaning derived from the text, may elucidate some of the paradoxes mentioned above by systematically explicating the Aqedah, the Binding of Isaac.

\section{Conceptual Framework}

The divine test of the Akedah will be unpacked through a hermeneutical paradigm composed of micro, meso, and macro-levels in a spiral model. While other theologians have found the three levels of "micro, meso, and macro" to be helpful in theology, ${ }^{34}$ these terms as applied to hermeneutics by Hans Küng ${ }^{35}$ and Fernando Canale ${ }^{36}$ suggest useful

${ }^{34}$ See Christopher R. Baker, Entering the New Theological Space: Blurred Encounters of Faith, Politics and Community (Burlington, VT: Ashgate, 2013), and Johannes Van der Ven, Ecclesiology in Context (Grand Rapids, MI: Eerdmans, 1996), 481.

${ }^{35}$ Küng described the three levels of "micro," "meso," and "macro" as referring to discrete theological ideas, comprehensive concepts of doctrinal theology and broad schools of theological thought, respectively. Hans Küng, Theology for the Third Millenium, trans. Peter Heinegg (New York: Doubleday, 1988), 134. Hans Küng's three levels of interpretation were adaptations from Thomas Kuhn's scientific components of a "disciplinary matrix": examples, models, and symbolic generalizations. Thomas S. Kuhn, The Structure of Scientific Revolutions, $3^{\text {rd }}$ ed. (Chicago, IL: University of Chicago Press, 1996), 182-186. However, Küng neglects to mention the fourth and deepest of Kuhn's scientific components, namely, values. Values "are more widely shared among different communities than either symbolic generalizations or models and they do much to provide a sense of community to natural scientists as a whole." In the present dissertation, deeply held intuitive values and symbolic generalizations will be addressed at the macro-level of hermeneutical principles.

${ }^{36}$ Canale described the three levels as micro-hermeneutics (biblical/textual principles of interpretation), meso-hermeneutics (theological/doctrinal principles of interpretation), and macrohermeneutics (the most inclusive ontological, epistemological, and articulation principles of interpretation). Fernando Canale, "Evolution, Theology, and Method, Part 3: Evolution and Adventist Theology," Andrews University Seminary Studies 42, no. 1 (2003): 172-173. See also Fernando Canale, "Deconstructing Evangelical Theology?" Andrews University Seminary Studies 44, no. 1 (2006): 104, and Fernando Canale, 
models for Bible interpretation. Specifically, Canale calls for a conscious re-construction

of the macro-hermeneutical principles directly from the scriptural text —instead of from

extra-biblical culture ${ }^{37}$ - as necessary for biblical coherence in the hermeneutical

endeavor. $^{38}$

If the macro-level is normed by the same text that provides the foundational data for

the micro and meso-level of analysis and is then used to provide the philosophical

framework to re-examine the linguistics of the text with a refreshed perspective, the

hierarchical model of micro, meso and macro levels is transformed into a continuous

hermeneutical circle as the process undergoes another turn. ${ }^{39}$ Further incorporation of the

“Paradigm, System, and Theological Pluralism,” The Evangelical Quarterly 70, no. 3 (1998): 195-218.

${ }^{37}$ Hellenistic philosophical concepts of the timeless, spaceless nature of ultimate truth have colored the picture of God since early Christianity and were imported into the belief system but not tested against the implicit ontology of the Bible. See Fernando Canale, A Criticism of Theological Reason: Time and Timelessness as Primoridal Presuppositions, Andrews University Seminary Doctoral Dissertation Series (Berrien Springs, MI: Andrews University Press, 1987), 399-409.

${ }^{38}$ Fernando Canale, "A Biblical Epistemology for Adventist Scholarship" (paper presented at the Fourth Symposium on the Bible and Adventist Scholarship sponsored by the Foundation for Adventist Education; Institute for Christian Teaching, Department of Education, General Conference of Seventh-day Adventists, Riviera Maya, Estado Quintana Roo, Mexico, 2008), 15.

${ }^{39}$ Circular models of interpretation contrast with linear or uni-directional models by implying a more dynamic dialectical method. Circular hermeneutics is understood as the utilization of both inductive and deductive reasoning. Inductive reasoning moves from observations of specific text details to the formation of larger concepts, the parts to the whole, while deductive reasoning is the application of previously formed paradigms (the whole) to the texts (the parts) under study. Grant R. Osborne, The Hermeneutical Spiral: A Comprehensive Introduction to Biblical Interpretation (Downers Grove, IL: InterVarsity Press, 2006), 385-386. Benedictus Spinoza, one of the earliest thinkers to recognize this hermeneutical relationship between the parts and the whole, advocated for historical and literary contextual sensitivity (the whole) in interpreting biblical data (the parts). Benedictus de Spinoza, Theological-Political Treatise, trans. Samuel Shirley (Indianapolis: Hackett Publishing, 2001), 86-104. Friedrich Schleiermacher inserted the reader/interpreter into the hermeneutical process as an important determinant and demonstrated that understanding a text requires certain assumptions of the human from outside the text in order for the text to be intelligible for them. Friedrich Schleiermacher, Schleiermacher: Hermeneutics and Criticism and Other Writings, ed. Andrew Bowie, Cambridge Texts in the History of Philosophy (Cambridge, UK: Cambridge University Press, 1998), 232; Anthony Thiselton, Thiselton on Hermeneutics: The Collected Works and New Essays of Anthony Thiselton, Ashgate Contemporary Thinkers on Religion: Collected 
biblical understanding of ultimate reality as temporal instead of timeless ${ }^{40}$ suggests a bidirectional hermeneutical model of a spiral may be preferable to the model of a closed circle ${ }^{41}$ Yet some models of the hermeneutical spiral demonstrate other conceptual weaknesses. Grant Osborne's model of a hermeneutical spiral starts by being grounded in the biblical text but the subsequent levels of interpretation and contextualization spiral away from the original platform of the text. ${ }^{42}$ The alternative suggested by this study is to incorporate the biblical text into the hermeneutical spiral model as the definitive central shaft, that is, as the long axis of the spiral. A textual axis links every level of the

Works (Burlington, VT: Ashgate Publishing, 2006), 452-453. Martin Heidegger, however, broke new ground when he broadened the hermeneutical task from the reader, text and literary context to the human being who finds him/herself already "thrown" into the world which is their context and asserted that the hermeneutical circle which leads to understanding reality (the whole) and self (the part) is the existential task of meaning facing every human being. Martin Heidegger, Being and Time, trans. Joan Stambaugh (Albany, NY: State University of New York Press, 1996), 127; Anthony Thiselton, New Horizons in Hermeneutics: The Theory and Practice of Transforming Biblical Reading (Grand Rapids, MI: Zondervan, 1992), 279. Heidegger's student, Hans Georg Gadamer, recognized the inescapable role of history in that both the text and the reader confront each other as end products of long cultural tradition (the text represents the larger world of established authority with thousands of years of tradition behind it, and the reader represents his or her personal tradition) which then requires a "fusion of horizons" for meaning to occur. Hans-Georg Gadamer, Truth and Method (New York, NY: Continuum, 1989), 305.

${ }^{40}$ See Canale, "Deconstructing Evangelical Theology," 115-124.

${ }^{41}$ One weakness of the hermeneutical circle model is that it is perceived as relative and viciously self-referential because it has no input outside itself, suggesting that the boundaries of current human comprehension limit it. A temporally determined or closed circle suggests that authority, even of the text, is inherently relative, non-objective, non-binding, and unescapably dependent on the interpretive language, tradition and past experience of the human beings encountering it. "What Heidegger described as 'preunderstanding', and Gadamer as 'effective history' - being immersed in temporality and its effects-is a hermeneutical circle always present in interpretation." Stephen Curkpatrick, "Authority of the Text: The Hermeneutical Question," Colloquim 33, no. 2 (2001), 140. Opening up the circular ends of this model to time, thus transforming the hermeneutical circle into a temporal hermeneutical spiral, reflects the interpreter's anticipation of future insights and their willingness to be interpreted and transformed through time by their ongoing engagement with the text.

${ }^{42}$ Osborne, Hermeneutical Spiral, 25-26. 
hermeneutical principles (micro, meso, and macro) to the text without widening the authority-gaps relative to the levels.

In such a model the connection between the levels and the text becomes crucial. For this study the overall principle for linking to the text is Sola Scriptura ${ }^{43}$ while the methodology is the historical-grammatical-literary method. But where can one enter this hermeneutical spiral? Since the biblical text is the long axis that norms all levels and is recognizably the most objective aspect of the hermeneutical spiral, it seems reasonable to enter the hermeneutical spiral from the micro-level beginning with a literary analysis of the text of Genesis 22:1-19.44 From this entry point, the Sola Scriptura principle undertakes an analysis of the literary aspects of the text by paying attention to its morphology, syntax, rhetoric and structure. Schematically, this entry point of micro-level hermeneutics corresponds to a close reading analysis of the narrative world in the text, the literary text is therefore the first step and central anchor for the other four worlds of meaning (behind the text, in front of the text, above the text and below the text).

The next level, meso-hermeneutics, extracts from these micro-hermeneutical findings the logic or theological concepts which undergird the details of the text. Meso-

${ }^{43}$ Sola Scriptura ("Scripture alone") was a Reformation principal that asserted Scripture to be the only infallible and sole basis of doctrine and church teaching above all church tradition and the control for testing subjective understandings of theology. Walter A. Elwell, Evangelical Dictionary of Theology (Grand Rapids, MI: Baker Book House, 2001), 58, 151, 571, 721; Kevin J. Vanhoozer, Craig G. Bartholomew and Daniel J. Treier, Dictionary for Theological Interpretation (Grand Rapids, MI: Baker Book House, 2005), 96, 368; William A. Dyrness and Veli-Matti Kärkkäinen, eds., Global Dictionary of Theology (Downers Grove: InterVarsity Press, 2008), 60, 734. Infallible is not the same as inerrant.

${ }^{44}$ Another reason for the micro-level as the entry point into the hermeneutical spiral is its ready accessibility for biblical scholars of differing persuasions, thus providing a common ground for starting the hermeneutical journey together. 
hermeneutics therefore seeks to understand the original theological concept from the world of the author (the meaning behind the text) for which the text acts as a window, enriched by the theological reflections of the other canonical writers which increase the transparency of the glass, ${ }^{45}$ that critiques the theological constructs from the world of the reader (the meaning in front of the text) as a reflecting mirror. The methodology on this level includes historical, ${ }^{46}$ inter-textual ${ }^{47}$ and typological analysis ${ }^{48}$ which incorporates the canonical breadth of the Tota Scriptura ${ }^{49}$ principle.

${ }^{45}$ This refers to the way the Bible interprets itself, intertextual analysis helps to clarify difficult texts by comparing them to corresponding but less ambiguous texts.

${ }^{46}$ There are two approaches to the method of historical analysis. The original approach, as conceived by Johann August Ernesti, was to recognize that the biblical narrative itself as a textual history of past events. In contrast, the modern approach to historical analysis "shifts the focus from the biblical narratives, as historical accounts of real events, to the events themselves (res) lying outside the narratives." Thus, growing knowledge of ancient history is used to fill in the missing context and details of the biblically events. John Sailhamer, The Meaning of the Pentateuch: Revelation, Composition, and Interpretation (Downers Grove, IL: IVP Academic, 2009),100-102. This study will accept the biblical narratives as actual past events interpreted with a theological purpose, this stance respects and recognizes the selective process that is inescapable in every written work of history.

${ }^{47}$ According to James Metzger, intertextual analysis recognizes the "profoundly dialogic" nature of all texts which can be appreciated from three different viewpoints: the author who is influenced by prior and contemporaneous material, the "implied authors" i.e., later editors/redactors that "beckon" the reader to consider the wider literary context of the final product, and "committed readers" who cannot avoid choosing or suppressing other texts in the endeavor to make sense of what they are studying. Metzger suggests "mapping one's intertextual decisions" is one way to enforce critical discipline for responsible hermeneutics. This dissertational study will map intertextual decisions by submitting interpretive hypotheses of the Aqedah to canonical testing at the meso-hermeneutical level. James A. Metzger, Consumption and Wealth in Luke's Travel Narrative, Biblical Interpretation Series, (Leiden, Boston: Brill, 2007), 51-56.

${ }^{48}$ Typology is defined by Edward Ellis as "historical correspondence and escalation or heightening (Steigerung), by which the divinely ordered prefigurement finds a complement in the subsequent and greater event." E. Earle Ellis, The Old Testament in Early Christianity: Canon and Interpretation in the Light of Modern Research, Wissenschaftliche Untersuchungen Zum Neuen Testament (Tübingen, GE: J.C.B. Mohr, 1991), 62-63. Because this dissertation will focus on the interpretation of the Aqedah and typological insights are contingent on that, a serious treatment of typology itself will be deferred to a future study.

${ }^{49}$ Tota Scriptura ("Total Scripture") was the concept that all of Scripture demonstrates unity as 
The third level, macro-hermeneutics, then attempts to systematically synthesize the theological constructs of the previous meso-level in order to trace the implications about God (the meaning above the text) and His cosmos (the meaning below the text) that the text has revealed. Ultimately, this level extracts a biblical philosophy by submitting to the Prima Scriptura ${ }^{50}$ principle in adopting the metaphysical presuppositions indicated by the text as the biblical framework for continuing exegesis.

Once these three levels have been traversed, the tentative conclusions of the macro-hermeneutical level can be employed as the biblical metaphysical framework for a another re-reading of the Aqedah, which re-examines the micro-hermeneutical level in order to test the biblical metaphysical framework for continuing congruence with the literary characteristics of the text. Then the tested metaphysical and literary findings interact for the second time at the meso-hermeneutical level of Aqedah meaning and logic and it is anticipated that the historical interpretations (both behind and in front of the text), and the vacuoles of narrative expression may gather added layers of significance because God's test of Abraham has now been biblically re-framed.

the Word of God, suitable for doctrine in its entirety. This contrasts with holding one part of Scripture over another in terms of truthfulness or inspiration, which is referred to as a canon within a canon. Vanhoozer, Dictionary for Theological Interpretation of the Bible, 88; John Calvin, The Calvin Handbook, ed. Herman J. Selderhuis (Grand Rapids, MI: Eerdmans, 2009), 380.

${ }^{50}$ Prima Scriptura ("Scripture first") historically referred to the priority of Scripture as divine revelation over other sources of revelation, which implied other sources of revelation such as nature, experience and reason were valid. N. Clayton Croy, Prima Scriptura: An Introduction to New Testament Interpretation (Grand Rapids, MI: Baker Academic, 2011), 130-134. This study asserts the priority property of Prima Scriptura in a fundamental manner-that Scripture is to establish normative presuppositions for biblical philosophy. In other words, Scripture is to continuously norm the foundational assumptions necessary for biblical metaphysics, logic, ethics, epistemology and aesthetics. 
Synthesizing the enriched meso-hermeneutical insights and deeper comprehension of the micro-hermeneutical constructs, the reader reassesses the biblical metaphysical framework again in the macro-hermeneutical level (above and below the text) and is open to revision before continuing the spiral another time. Thus, each re-visiting of the narrative through the interlinking levels of hermeneutics leads to testing and developing the hermeneutical skills that uncover sequentially more facets of the worlds of meaning in the text.

In summary, the three spiraling levels of micro, meso, and macro hermeneutics build upon one another continuously with each level simultaneously normed by the textual axis through the overarching principle of Sola Scriptura. The principle of Sola Scriptura includes the textual emphasis of Sola Scriptura in the micro-level, the canonical influence of Tota Scriptura in the meso-level, and the metaphysical depth of Prima Scriptura in the macro-level and on the interpreter's personal worlds of meaning. ${ }^{51} \mathrm{~A}$ tentative methodology of how this conceptual framework can be realized through an application to the Aqedah will now be presented.

\section{Methodology}

In order to unbind (interpret) the test of the Aqedah, four steps will ensue. These steps will be accomplished over six chapters.

\footnotetext{
${ }^{51}$ This study does not presume to do a comprehensive study of all three levels but will demonstrate enough of the three levels to illustrate the inter-relationships between them and the benefit of a more comprehensive hermeneutical approach in acknowledging the multiple spheres of meaning as normed by the text.
} 
In chapter two, I will do a comparative analysis of Jon Levenson's The Death and Resurrection of the Beloved Son and Terence Fretheim's Abraham: Trials of Family and Faith using the tri-level hermeneutical model for clarity. The analysis will uncover their micro, meso, and macro-hermeneutical concepts in relation to the text. This prepares the study for the application of the hermeneutical model to the Aqedah using the historicalgrammatical ${ }^{52}$ method in the subsequent chapters of this project.

In chapter three I will embark on a micro-level analysis of the Aqedah itself, examining the text directly to identify its grammatical, syntactical, stylistic and structural characteristics in order to uncover the necessary postulates that constitute the divine test of Abraham. The focus will be on grappling with the narrative details, their literary roles and linguistic relation to each other as directed by the text's own structure.

In chapter four, integration of the previous micro-hermeneutical findings will be sought using tenets of meso-hermeneutical principles necessary to illuminate the historical world behind the text and biblically correct the world of meaning in front of the text in the person of the reader. ${ }^{53}$ Once again, the text itself will direct and norm the fusion of questions and answers for understanding. Resulting theological constructs or hypotheses will then submit to canonical testing in a systematic manner. ${ }^{54}$

${ }^{52}$ Corley, Biblical Hermeneutics, 21-38.

${ }^{53}$ All the meanings that exist between the reader and the text are impossible to map within one study. This study will present examples of personal and existing theological meanings that readers may bring to the task of interpretation and show how these meanings can be corrected by a text-based methodology in chapter three on meso-hermeneutics.

${ }^{54}$ The canon tests the theological constructs of the meso-level of hermeneutics by providing the broader biblical background for divine tests, sacrifice, substitution, worship, and other themes found in the Aqedah. Valid theological constructs will be congruent with the canonical exposition of that particular 
In the fifth chapter, implications for a biblical macro-hermeneutic will be explored through a systematic synthesis of the previous two interpretive levels revealed by the text. This level of macro-hermeneutics will elucidate theistic and cosmological assumptions of the text, the meanings above and below the text. Special attention will be given to the divine intentionality of the test as the theo-centric perspective is what holds the parts of this complex narrative together and establishes its significance in the canon.

Throughout this study the interdependent relationship between the micro, meso, and macro hermeneutical levels for interpreting the Aqedah test will be explored. The complimentary roles of the meanings behind and in front of the text and the meanings above and below the text will also be evaluated. Finally, in the sixth chapter, an assessment of the hermeneutical model and the Aqedah with recommendations for continuing the hermeneutical process will be discussed.

\section{Scope and Delimitations}

For this present study, my investigation of the works of Jon Levenson and Terence Fretheim will focus on their treatment of the Aqedah. Other works by the authors will be consulted if needed to clarify their interpretation of the Aqedah. Due to the twofold intentions of this project, to create and apply a hermeneutical model to the Aqedah, a comprehensive survey of the theological history of the Aqedah will not be included in this dissertation as the chosen perspective of the study is not historical theology but hermeneutical analysis and application. Nevertheless, the major strains of theological

theme for the biblical canon assumes coherence in the character of God. 
reflection on the Aqedah will be referenced appropriately on the three hermeneutical levels.

Scripture holds many overt and implicit allusions to the Aqedah throughout the canon. In order to keep this study manageable, from the New Testament I have chosen to limit myself to the insights of Jesus and Paul on Abraham's sacrifice. From the Old Testament, verses dealing with child sacrifice will be included for primary relevance though this study cannot provide a comprehensive coverage of many other interesting and related themes. Regarding issues of historical-critical, social-historical, and reader response methods, these approaches to interpretation will be explored only as far as is necessary to demonstrate the advantages of the historical-grammatical-literary approach to the Aqedah. 


\section{CHAPTER 2}

\section{ANALYSIS OF LEVENSON”S AND FRETHEIM'S INTERPRETATIONS \\ OF THE AQEDAH}

\section{Introduction}

"Not all Hebrew narrative is a version of the Binding of Isaac, with its stark conjunction of fire, wood, knife and impending sacrifice, its breathtaking violation of human conceptions in man's terrible exposure before God."' The Aqedah or Binding of Isaac (Genesis 22:1-19) is one of the most dramatic and gripping narratives in the Bible where a father is called upon to sacrifice his only son to God. Yet, even the most moving stories passed down over long periods of time can start to lose their potency for the religious community and lapse into a telling that is "uneventful, bland, routine, and entirely unremarkable. . . biblical writings, in such a situation become assimilated into the function of creeds: they become primarily institutional mechanisms to ensure continuity of corporate belief and identity."2 If the Aqedah risks being assimilated by the religious

\footnotetext{
${ }^{1}$ Robert Alter, "Biblical Imperatives and Literary Play" in Jason P. Rosenblatt and Joseph C. Sitterson Jr., "Not in Heaven": Coherence and Complexity in Biblical Narrative (Bloomington, IN: Indiana University Press 1991), 18.

2 Anthony Thiselton, New Horizons in Hermeneutics, 8. The same process happens in personal narratives. Wittgenstein writes, "The aspects of things that are most important for us are hidden because of their simplicity and familiarity. (One is unable to notice something-because it is always before one's eyes.) The real foundations of his enquiry do not strike a man at all! Unless that fact has at some time
} 
community into an ancient mantra of unquestioning obedience to the highest moral authority, it will be dismissed by a postmodern generation suspicious of metanarratives manipulated for ideological control. ${ }^{3}$ Since this is a genuine possibility, how can a reader, centuries later, encounter and hear a familiar biblical work as a living text again? ${ }^{4}$

Paul Ricoeur provides an answer, "It is by interpreting that we can hear again,", and Anthony Thiselton underscores that "Luther and Calvin argued that the word of God encounters readers most sharply when it addresses us as adversary, to correct and to change our prior wishes and expectations." ${ }^{\prime 6}$ If they are right, the Aqedah is a worthwhile

struck him.-And [sic] this means we fail to be struck by what, once seen, is most striking and most powerful." Ludwig Wittgenstein, Philosophical Investigations, trans. G. E. M. Anscombe (Oxford, UK: Basil Blackwell, 1986), sect. 129.

${ }^{3}$ Jean Lyotard famously described the skeptical postmodern mindset toward the genre of a totalizing meta-narrative: "Simplifying to the extreme, I define postmodern as incredulity toward metanarratives. .. . The narrative function is losing its functors, its great hero, its great dangers, its great voyages, its great goal." Jean-François Lyotard, "The Postmodern Condition: A Report on Knowledge," in A Postmodern Reader, ed. Linda Hutcheon Joseph P. Natoli (Albany, NY: State University of New York Press, 1993), 72. The reason for skepticism is that historically, groups have tried to control, unify and legitimize their existence through narrative systems. Linda Hutcheon, "Incredulity toward Metanarrative: Negotiating Postmodernism and Feminisms," in Collaboration in the Feminine: Writings on Women and Culture from Tessera, ed. Barbara Godard (Toronto, Canada: Second Story Press, 1994), 186.

${ }^{4}$ Barthes distinguishes between a work, which is a concrete object like a book occupying bookspace in a library or store, and the text which is a methodological field of study. "While the work is held in the hand, the text is held in language: it exists only as discourse." Roland Barthes, "From Work to Text," in Textual Strategies: Perspectives in Post-Structuralist Criticism, ed. Josue V. Harari (Ithaca, NY: Cornell University Press, 1979), 74-75. 1967), 351.

${ }^{5}$ Paul Ricoeur, The Symbolism of Evil, trans. Emerson Buchanan (Boston, MA: Beacon Press,

${ }^{6}$ Thiselton, New Horizons, 9. Thiselton goes on to agree with Barthes that a text requires active collaboration in order to come to life, much like the performance of a musical score. Barthes reminds his readers that there are two roles filled by different groups to a musical work; one group interprets/executes the work and the other listens or accepts the interpretation. The modern critic assimilates both roles in analysis. Refusal to listen and critique or being merely content to "consume" it - leads to boredom if the work is not easily ingested. Barthes, "From Work to Text," 80. 
hermeneutical challenge due to its spare ancient style ${ }^{7}$ and daunting moral content. ${ }^{8}$

Consistent with its self-declared nature as a divine test, the Aqedah test is a genuine

"text" which is "not so much a 'given' as an invitation to activity."

This study begins by analyzing two contemporary scholars who are exemplary in their field and bring different hermeneutical approaches to the Aqedah. Jon Levenson's and Terence Fretheim's explications of the Aqedah in The Death and Resurrection of the Beloved Son and Abraham: Trials of Family and Faith, respectively, will be analyzed through the filter of three hermeneutical levels, namely, micro, meso, macrohermeneutics. Each eminent scholar brings fresh insights and utilizes source materials differently.

Levenson's explication of the Aqedah in The Death and Resurrection of the Beloved Son happens to be an excellent example of the historical critical method ${ }^{10}$

7 "The fact that the text is ancient and that its characteristic narrative procedures may differ in many aspects from those of modern texts should not lead to a condescending preconception that the text is therefore bound to be crude or simple." It is only under the imposition of aesthetic laws such as "the law of stylistic unity, of noncontradiction, or nondigression" and "nonrepetition," that ancient texts were sometimes deemed "composite, deficient, or incoherent." Robert Alter objects mightily to this prejudice based on assumed modern literary criteria, "If just these four laws were applied respectively to Ulysses, The Sound and the Fury, Tristam Shandy, and Jealousy, each of those novels would have to be relegated to the dustbin of shoddily 'redacted' literary scraps." Improved narrative scholarship has uncovered complexity, subtlety, and unique structures of formal organization previously unrecognized in the Aqedah. For literary analysis, see Robert Alter, The Art of Biblical Narrative (New York, NY: Basic Books, 1981), 21; aesthetic laws are mentioned in Tzvetan Todorov, The Poetics of Prose, trans. Richard Howard (New York, NY: Cornell University Press, 1977), 53-65.

\footnotetext{
${ }^{8}$ The moral tension of the Aqedah is heightened by other verses in the Pentateuch such as "You shall not do so to the Lord your God; for every abominable thing which the LORD hates they have done for their gods, for they even burn their sons and daughters in the fire to their gods. Everything that I command you, you shall be careful to do; you shall not add to it or take from it," Deut 12:31-32.

${ }^{9}$ Thiselton, New Horizons in Hermeneutics, 57.

${ }^{10}$ The historical-critical method is the diachronic study of text formation. It is included in the
} 
enriched by sociological insights on the diachronic development of religious belief. The canon of the Hebrew Bible (Old Testament for Christians) comprises his context for exegesis at the micro-hermeneutical level while historical critical methods are employed at the meso-hermeneutical level for reconstructing the historical-social background behind the text. The New Testament, and second temple rabbinic sources are referenced in intertextual dialogue for illuminating the meso-hermeneutical level of the world in front of the text. As an observant Jewish scholar, ${ }^{11}$ Levenson handles the Christian community's New Testament (NT) as another mishnaic interpretation. ${ }^{12}$ In his exposition

critical or analytical phase of an interpretive process, often the second phase of a sequence of three. Karl Barth's three phrases of interpretation were Observation (Beobachtung, explication, sensus), Reflection (Nachdenken, meditation), and Appropriation (Aneignung, application, usus). Karl Barth, Church Dogmatics, trans. Geoffrey W. Bromiley, G. T. Thomson, and Harold Knight, 14 vols. (New York, NY: T\&T Clark, 2010), 1:2, 736; Paul Ricoeur explained his three-phased hermeneutical arc as (Mimesis 1 ) preunderstanding - the reality that the reader brings to the text, $\left(\right.$ Mimesis $\left._{2}\right)$ configuration or emplotment- the ordering and transformation by the text of particular aspects of reality into a coherent whole, and (Mimesis ${ }_{3}$ ) intersection - the effect or change of the hearer's reality from reading the text. Mark I. Wallace, The Second Naivete', 52, 55-56; Paul Ricouer, Time and Narrative, trans. Kathleen McLaughlin and David Pellauer, 3 vols. (Chicago, IL: University of Chicago Press, 1984), 1:52-87; David Klemm coined Ricoeur's three stages as "first naiveté," "critique," and "second naiveté." David Klemm, The Hermeneutical Theory of Paul Ricoeur (Lewisburg, PA: Bucknell Press, 1983), 69.

${ }^{11}$ Levenson describes himself as "an observant Jew, I teach Hebrew Bible at a liberal Protestant divinity school in a university of Puritan origin and I am a member of the Catholic Bible Association and have contributed repeatedly to its journal." Jon D. Levenson, The Hebrew Bible, 34.

12 Levenson critiques Gerhard von Rad and Soren Kierkegaard's tradition driven interpretation of the Aqedah for focusing almost exclusively on Abraham's faith in contrast to his obedient act. "In subscribing to this view, von Rad, like Kierkegaard a Lutheran, replicates the most basic paradigm movement in the theology of his own tradition, the Pauline paradigm that affirms faith in contradistinction to deeds as the supreme and defining element in spiritual authenticity. Abraham is not rewarded so much for his act of slaughtering his beloved son - an act halted only after he has gone so far as to pick up the knife (v 10) — as for his faith in the promise that Isaac shall live. . . . The Aqedah, in short, tests whether Abraham is prepared to surrender his son to the God who gave him. To say, with Kierkegaard and von Rad, that he is prepared so to do [sic] because through faith he expects to receive Isaac anew (as indeed happens) is to minimize the frightfulness of what Abraham is commanded to do. It is also, I hope to show, to miss one of the key ambiguities and energizing tensions of the story." Jon D. Levenson, The Death and Resurrection of the Beloved Son, 126.

To be fair, von Rad's commentary on Genesis 22 is more nuanced and includes multiple loci for meaning. Von Rad argues, "one must from the first renounce any attempt to discover one basic idea as the 
of the Akedah, Levenson does not directly address the philosophical implications of the world above or below the text which constitute the macro-level of hermeneutics. However, from the justifications given for choices on the other two levels, some implications may be traced to his macro-hermeneutical assumptions.

The second theologian for comparison, Terence Fretheim, includes the New Testament as part of the Christian canonical context for exegesis at the microhermeneutical level. On the meso-hermeneutical level, Fretheim takes very seriously the present-day reader's concerns elicited by this ancient but troubling narrative, these address the world of meaning behind and in front of the text. ${ }^{13}$ Finally, on the macrohermeneutical level, Fretheim's close reading of the Aqedah text drives him to probe

meaning of the whole. There are many levels of meaning, and whoever thinks he has discovered virgin soil must discover at once that there are many more layers below that... The exposition is much more accurate when it discovers in the narrative above all the idea of a radical test of obedience. That God, who has revealed himself to Israel, is completely free to give and to take, and that no one may ask 'What doest thou?' (Job 9.12; Dan 4.32), is without doubt basic to our narrative. . . But one must be careful not to interpret the story in a general sense as the question about Abraham's willingness to obey. . . it concerns something much more frightful than child sacrifice. It has to do with a road out into Godforsakenness. . . .Yahweh often seems to contradict himself, that he appears to want to remove the salvation begun by himself from history." Gerhard von Rad, Genesis, 243-244.

${ }^{13}$ Fretheim believes it is appropriate to address modern day concerns to an ancient text because in the existential approach, the ancient text challenges the present reader in an immediate and confrontational manner. Fretheim invites the reader to ponder, "Should every parent wonder: Might my child be

endangered by God? Is the God whom we worship a God who might force us to choose between the love of our children and the love of God? ... Why the praise for God's providing? If God set up the test in the first place, why should God be praised for a resolution?" Terence E. Fretheim, Abraham, 119. 
traditional assumptions about divine epistemology, an aspect of the world of metaphysical meaning above the text.

Since Levenson's and Fretheim's canons differ, micro-hermeneutical contexts for literary analysis are not aligned. ${ }^{14}$ In addition, the relative weight of authority given to different sources and the scope of context at the meso-hermeneutical level are not justified with explicit criteria. ${ }^{15}$ Like other interpreters who adopt the nest-like paradigms ${ }^{16}$ of their faith or scholarly communities without being aware of all the implications, ${ }^{17}$ each scholar speaks without clarifying their deepest philosophical foundations. Unacknowledged, these presuppositions at the macro-hermeneutical may powerfully and invisibly influence the conceptual tasks at the micro and meso-

\footnotetext{
${ }^{14}$ Since the number of contexts available for any interpretation of a biblical text are "legion" and "never self-evident": the "work of the author," "redacted pericope," "biblical book," "subsection of the Jewish canon," "entire Hebrew Bible," "Christian Bible," "exegetical traditions of the church or rabbis," etc., Levenson finds it "disingenuous and shortsighted to accuse proponents of any one of them of "taking the passage out of context." Levenson, The Hebrew Bible, 56.

${ }^{15}$ Instead of justification, subjective techniques are sometimes used to situate the reader's expectations. One is to mention extremes as parameters and recommend balance, implicitly suggesting the author's proposed stance as being that. For example, "while the reader ought not to discount the unusual, frightening character of God's command [in the Akedah], it ought not be exaggerated either." Terence Fretheim, "God, Abraham and the Abuse of Isaac," Word and World 15, no. 1 (1995), 50.

${ }^{16}$ Wittgenstein referred to the paradigm of beliefs built or absorbed over time as a "nest of propositions." Ludwig Wittgenstein, On Certainty (Oxford, UK: Blackwell, 1969), Section 225.

${ }^{17}$ For instance, Levenson writes, "Another principle Christians are tempted to use is the Christocentric principle, 'The boldest statement of this theology is Luther's own remark in derogation of the epistle of James: "What does not teach Christ is not apostolic, even though St. Peter or Paul taught it: again, what preaches Christ would be apostolic, even though Judas, Annas, Pilate and Herod did it."” Levenson astutely points out that full assumption of this principle would pre-emptively dismiss all nonChristocentric insights from Jewish scholars as theologically invalid. Levenson, The Hebrew Bible, 73.
} 
hermeneutical levels. Our discussion of Levenson and Fretheim should begin, then, with their stance toward their scholarly communities.

\section{Levenson and the Historical-Critical Method}

Jon Levenson identifies himself as a historical critical scholar ${ }^{18}$ but rejects exclusive reliance on any one interpretive methodology for scripture. His critique of the domination of biblical scholarship by the historical-critical method is penetrating and worth reviewing. Theoretically, Levenson points out that no "self-consciously universalistic and rationalistic method" can adequately "serve as the vehicle of any particularistic religious confession." ${ }^{19}$ Methodologically, the historical-critical method privileges the historical context while shortchanging the literary context of the completed work that ultimately grounds the beliefs of a religious community. Pragmatically, the exclusive academic focus on historicism and empiricism neglects the "transhistorical value" of "suprahistorical truth" which sustains "the faith and belief upon which all learning—and not only biblical studies—depends." ${ }^{20}$ In other words, the historical-critical method ends up undermining its own base.

18 "Were we historical critics to be classed as a religious body, we should have to be judged a most miniscule sect indeed - and one with a pronounced difficulty relating to groups that do not accept our beliefs." Levenson, Hebrew Bible, 120.

${ }^{19}$ And since historical-critical methods are preferred tools of Christianity, "the practical consequence has been the development of a host of historical-critical interpretations that are really only rewordings or recastings of traditional Christian views." Levenson, Hebrew Bible, xiii.

20 "The Bible (under any definition) cannot survive methods that are themselves unable to transcend the limitations of historicism and empiricism. For such methods can at best only describe a range of canons and cultures but can never explain why we should concentrate on one rather than another. Indeed, a historicism afraid to acknowledge normative judgments about suprahistorical truth eventually deteriorates into historical relativism and experiences mounting difficulty articulating the transhistorical value of 
However, the gifts of historical criticism are not to be dismissed:

Historical criticism has indeed brought about a new situation in biblical studies. The principal novelty lies in the recovery of the Hebrew Bible as opposed to the Tanakh and the Old Testament affirmed by rabbinic Judaism and Christianity, respectively. Jews and Christians can, in fact, meet as equals in the study of this new/old book, but only because the Hebrew Bible is largely foreign to both traditions and precedes them. This meeting of Jews and Christians on neutral ground can have great value, for it helps to correct misconceptions each group has of the other and to prevent the grievous consequences of such misconceptions, such as anti-Semitic persecutions. ${ }^{21}$

Indeed, historical critical insights can "add vitality to an exegetical practice that easily becomes stale and repetitive" but too often, the methodology has been used as a tool to dissect, not improve understanding. ${ }^{22}$ Therefore, Levenson's hermeneutical approach to the Bible includes a broad spectrum of historical, sociological, literary,

historical study itself.” Levenson, Hebrew Bible, xiv, 4.

${ }^{21}$ Levenson, Hebrew Bible, 105. Historical-critical methods can also be melded with literary analysis: "It may actually improve our understanding of the Torah to remember that it is quoting documents, that there is, in other words, a purposeful documentary montage that must be perceived as a unity, regardless of the number and types of smaller units that form the building blocks of its composition. Here, the weight of literary interest falls upon the activity of the final redactor, whose artistry requires far more careful attention than it has hitherto been accorded." Joel Rosenberg, "Meanings, Morals, and Mysteries: Literary Approaches to the Torah," Response 9, no. 2 (Summer 1975): 67-94.

${ }^{22}$ Levenson, Hebrew Bible, 105. "I repeat that I am convinced that the restoration of historical context to the Bible can help bring it alive and add a vast depth and meaning to our study of it. The problem to which I am pointing is that much biblical scholarship is not pursuing its historical-critical work as part of any such hermeneutic of retrieval. Instead its operative technique is too often a trivializing antiquarianism, in which the bath water has become more important than the baby, and the enormous historical and philological labors are not justified by any reference to any larger structure of meaning." Levenson, Hebrew Bible, 99. This observation is echoed by other scholars. Robert Alter, Genesis, 39-41; J. P. Fokkelman, Narrative Art in Genesis: Specimens of Stylistic and Structural Analysis (Eugene, OR: Wipf \& Stock, 1991), 1-3. Some of the historical-critical features are addressed in footnote 177, pgs. 226-228. 
textual criticism and also embraces the insights and exegetical tools of traditional interpretation, including the rich heritage of rabbinic literature.

He argues, "Though fundamentalists will not see the value [of historical criticism], nor historicists the limitations, intellectual integrity and spiritual vitality in this new situation demand the careful affirmation of both." ${ }^{23}$ This is necessary because historical critics "challenge the historicity of the foundational events (e.g., Sinaitic revelation, the resurrection of Jesus), traditional ideas of authorship," and tend to "concentrate on contradictions which they then allow to stand." But once they dismember the text, according to Levenson, "they lack a method of putting it back together again." It is the traditionalists who have developed methods to harmonize these known contradictions; it is they who attempt to "preserve the unity of the text and its religious utility." 24

Thus, Levenson urges biblical scholars to master multiple methodological approaches, utilize them fruitfully and remain prudently cognizant of their limitations. Methodologically, "the dignity of both traditional interpretation and of modern criticism depends on a careful separation of the two and a reengagement on new terms." ${ }^{25}$ Moberly sees Levenson's own "position within a historically rooted, living, transformative, and

\footnotetext{
${ }^{23}$ Levenson, Hebrew Bible, 105.

${ }^{24}$ Levenson, Hebrew Bible, 2.

${ }^{25}$ Levenson, Hebrew Bible, 15.
} 
critically aware religious community offers great potential for insight and appropriation." ${ }^{26}$

\section{Biography of Jon Levenson}

Jon Levenson is the Albert A. List Professor of Jewish Studies at Harvard Divinity School. ${ }^{27}$ He obtained his B.A. in English at Harvard College in 1971, his M.A. and Ph.D. from the Department of Near Eastern Languages and Civilizations at Harvard University in 1974 and 1975, respectively ${ }^{28}$ His areas of expertise include theological traditions in ancient Israel (biblical and rabbinic periods); literary interpretation of the Hebrew Bible, midrash, history of Jewish biblical interpretation, modern Jewish theology and Jewish-Christian relations.

From 1975-1982, he was Assistant Professor of Religion and Biblical Studies at Wellesley College. This was followed by six years as Professor of Hebrew Bible in the Divinity School of the University of Chicago from 1982-1988. Since 1988 to the present, he has been the Albert A. List Professor of Jewish Studies at the Divinity School and an

\footnotetext{
${ }^{26}$ Walter Moberly, Book Review of "Levenson, Jon D. The Death and Resurrection of the Beloved Son: The Transformation of Child Sacrifice in Judaism and Christianity," Journal of Religion 75, no. 2 (April 1995), 262.

${ }^{27}$ Levenson, Hebrew Bible, back cover.

${ }^{28}$ Jon Levenson, "Curriculum Vitae," accessed 2 January 2017, http://hds.harvard.edu/files/hds/files/levenson_cv_july2013.pdf.
} 
Affiliate Member of the Department of Near Eastern Languages and Civilizations, both of Harvard University.

His prolific writings have garnered prestigious awards. His book Resurrection and the Restoration of Israel: The Ultimate Victory of the God of Life won the National Jewish Book Award and the Biblical Archeology Society Publication Award in the category of Best Book Relating to the Hebrew Bible published in 2005 or 2006. The American Library Association listed as one of the Outstanding Academic Titles for 2013, his book Inheriting Abraham: The Legacy of the Patriarch in Judaism, Christianity, and Islam. The book examined in this study, The Death and Resurrection of the Beloved Son: The Transformation of Child Sacrifice in Judaism and Christianity was praised by Walter Moberly as "the rare experience of a fresh, insightful, and thought-provoking thesis that combines the probing of fundamental religious issues with detailed exegesis of the biblical texts, and it is lucidly written." ${ }^{29}$

\section{Levenson's Interpretation of the Aqedah}

Levenson's interpretation of the Aqedah in his book The Death and Resurrection of the Beloved Son progresses through three sets of texts related to the concept of firstborn sacrifice. ${ }^{30}$ With the first set, he posits that the literal sacrifice of the first sons to YHWH was within religious practice parameters in the early history of Israel and in the nations around her. He cites Exod 22:28-29 ("You shall give me the firstborn among your

\footnotetext{
${ }^{29}$ Moberly, "Book Review of Levenson's Death and Resurrection,” 262.

${ }^{30}$ Levenson, Death and Resurrection, 3-17
} 
sons" commanded here without any mention of animal redemption), Mic 6:7 ("Shall I give my first-born for my transgression, the fruit of my body for my sins?"), Gen 22:1-19 (The Aqedah), Judg 11:29-40 (Sacrifice of Jephthah's daughter), and 2 Kgs 3:26-27 (Sacrifice of the son of the king of Moab) as supportive evidence. ${ }^{31}$

Second, the sacrifice of the firstborn could be fulfilled by redemption through substitution of an animal or another favored child in its place. In Genesis, the motif of the death and resurrection of the firstborn or designated favored child was either literally (Abel) or symbolically (Isaac, Jacob, Joseph) experienced by key characters in the book. Corporate instructions for the newly formed nation later allowed substitutions for the beloved son by a paschal lamb, Levitical service, monetary ransom, or even Nazaritehood. ${ }^{32}$

The third and last cluster of texts reject ritual child sacrifice as a legitimate part of the religion of Israel. According to Jeremiah, YHWH denounces these as rituals "which I never commanded, never decreed, and which never came into my mind" (Jer 19:5). ${ }^{33}$ Levenson argues that the intensity of adamant disavowals ironically implies there was an existing tradition to attack, one that had presumed "that YHWH desires it." ${ }^{{ }^{34}}$ In fact, Ezekiel discloses that YHWH did give them "laws that were not good and rules by which

\footnotetext{
${ }^{31}$ Levenson, Death and Resurrection, 5, 16.

${ }^{32}$ Levenson, Death and Resurrection, 4, 21, 46-51, 55-81.

${ }^{33}$ See also Jer 7:31, 32:35.

${ }^{34}$ Levenson, Death and Resurrection, 5, 15.
} 
they could not live; when they set aside every first issue of the womb, I defiled them by their very gifts—-that I might render them desolate" (Ezek 20:25).

Levenson believes the Aqedah was not a sacrificial punishment or atonement sacrifice for either Isaac or Abraham's sins, but belonged in the category of first fruit offerings with the firstborn male from the womb. ${ }^{35}$ The meaning is "God's portion must be the first and the best." ${ }^{36}$ If this paradigm is accepted, then Isaac is the natural choice for sacrifice and what is being tested in Abraham through the Aqedah becomes clearer.

The test announced in v.1, then, is a test of which is stronger, Abraham's fear of God or his love of Isaac, and once the answer is in, the sacrifice therein commanded can be called off . ... It may also be the case that Abraham's fear of God, that is, his reverential obedience to YHWH, has altogether overwhelmed his love of Isaac in the sentence structure no less than in the event, so that 'the one whom you love, Isaac' is no longer at issue. The only point is that which the entire trial aims to prove that Abraham's obedience is absolute and uncompromising. Just as the trial begins with 'God['s] put[ting] Abraham to the test" with no mention of Isaac, so does it end with God's acknowledgment that Abraham fears him without any mention of Isaac's name or the countervailing force of his paternal affection for the beloved son whom he has refused to withhold (v 12). ${ }^{37}$

Levenson claims that over time as the role of the son became more prominent in Israelite consciousness, Isaac's voluntary obedience in the Aqedah provided an archetypal model for "a race exemplary for its martyrs." ${ }^{\prime 38}$ The Aqedah was then seen as an initiation rite of sacrificial surrender for father and son where Abraham, "in order to

\footnotetext{
${ }^{35}$ Levenson, Death and Resurrection, 15.

${ }^{36}$ Levenson, Death and Resurrection, 59.

${ }^{37}$ Levenson, Death and Resurrection, 137.

${ }^{38}$ Levenson, Death and Resurrection,134.
} 
play his role in the providential drama, must surrender his son to God so that the son may assume his own foreordained role." ${ }^{39}$ A chosen, elected son must thereby accept "the costly nature of God's choice" 40 if he is to enjoy the unique relation to God that comes with it.

\section{Analysis of Levenson's Hermeneutics}

\section{Micro-Hermeneutic}

The exegetical discussion of the Aqedah found in chapter twelve discusses textual details that constitute the micro-hermeneutical level of analysis: the scope of meaning for terms (test, ${ }^{41}$ hinenni, ${ }^{42}$ worship ${ }^{43}$ ), structure (four designations of sacrificial victim,,${ }^{44}$ parallels to Gen 12:1-2 ${ }^{45}$ ), repetition (abbreviated denotations of Isaac, ${ }^{46}$ father-son relation emphasized, ${ }^{47}$ obedience matches commands, ${ }^{48}$ intensification: two walked as

${ }^{39}$ Levenson, Death and Resurrection, 142.

${ }^{40}$ Moberly, "Book Review of the Death and Resurrection," 262.

${ }^{41}$ Levenson, Death and Resurrection, 125-126.

${ }^{42}$ Levenson, Death and Resurrection, 126-127, 137.

${ }^{43}$ Levenson, Death and Resurrection, 130-131.

${ }^{44}$ Levenson, Death and Resurrection, 127.

${ }^{45}$ Levenson, Death and Resurrection, 128, 140-141.

${ }^{46}$ Levenson, Death and Resurrection, 128-129, 137.

${ }^{47}$ Levenson, Death and Resurrection, 129

${ }^{48}$ Levenson, Death and Resurrection, 129. 
one, ${ }^{49}$ two angelic affirmations ${ }^{50}$ ), stylistic technique (fragmentary speeches support silence and ambiguity ${ }^{51}$ ), reversal (wood on Isaac then Isaac on wood $^{52}$ ), pace (slow startsudden rescission ${ }^{53}$ ), and near-homophonies (nissa $\hat{,}{ }^{54}$ yerre $\left.\bar{e}^{-55}\right)$.

Levenson seamlessly weaves the explication of micro-hermeneutics to their mesohermeneutical implications for theology. The benefit of tying the two levels closely together is that the relevance of the micro-hermeneutical details is made immediately apparent to the reader. Close linkages of these two levels reveal the natural affinity of hermeneutical levels to co-interpret and illuminate each other. ${ }^{56}$ Since hermeneutics is also interested in the logic and rationale for interpretive decisions, three examples on the scope of meaning and literary structure will demonstrate the way Levenson argues for interpreting the text.

Exegetes do not always agree on the scope of meaning for a particular term. Gerhard von Rad hears in the narrator's initial framing of an imposed construct from a

${ }^{49}$ Levenson, Death and Resurrection, 134

${ }^{50}$ Levenson, Death and Resurrection, 138

${ }^{51}$ Levenson, Death and Resurrection, 131-132

${ }^{52}$ Levenson, Death and Resurrection, 136

${ }^{53}$ Levenson, Death and Resurrection, 137

${ }^{54}$ Levenson, Death and Resurrection, 139

${ }^{55}$ Levenson, Death and Resurrection, 139

${ }^{56}$ Fluid movement from an exegetical detail in the text to a theological meaning and to its philosophical implications is sometimes presented to support a preferred meaning. If ambiguity or inconsistency exists between the levels, this is often overlooked or glossed over. 
godly source ("God tested Abraham"), a literary hint to the reader that "God does not desire the death of Isaac." ${ }^{57}$ Levenson disagrees, "Nothing in the verb used (nissa) implies that the act commanded will not be carried to completion, that Isaac will only be bound and not sacrificed on the altar." ${ }_{58}$ Levenson has narrowed the scope of meaning for test (nissa) to an operational term without the implication that it is not meant to be taken literalistically to the end. ${ }^{59}$ Both interpreters therefore argue their interpretation from presuppositions on what a test is and is not, without disclosing those premises to the reader. ${ }^{60}$

In contrast to his stringent position above, Levenson accepts an expansive scope of meaning for hinneni in the Akedah. He prefers E. A. Speiser's “one-word translation 'Ready""61 over the more common translation "Here I am," and the literal translation of the Hebrew "Behold me." Levenson's reasons, "in none of these verses is there an

${ }^{57}$ Levenson, Death and Resurrection, 125. Von Rad characterizes the test as a temptation (Anfechtung): "The reader is told in advance, however, that the story concerns a temptation given by God, a demand which God did not intend to take seriously.... He [the narrator] has not caused his reader any premature excitement regarding a horrible experience." Von Rad, Genesis, 239. Nahum Sarna agrees with such implications for this test; "the reader is informed in advance that God is only testing Abraham and does not want the sacrifice for His own needs." Nahum Sarna, The JPS Torah Commentary: Genesis (New York, NY: The Jewish Publication Society, 1989), 393.

${ }^{58}$ Levenson, Death and Resurrection, 126.

${ }^{59} \mathrm{~A}$ test is often an artificially imposed stress in the form of a question or command that does not necessarily reflect the ignorance or direct need of the tester regarding those points. On the other hand, a test can also be set up to satisfy the tester's lack of knowledge or arise from a genuine need (of the tester, testee, or prevailing circumstances).

${ }^{60}$ The narrator of the Aqedah does not specify what a test is, what kind of a test this is, or how a divine test might differ from a human test. The term itself was not used before this point in the book of Genesis. Because Levenson does not share his underlying rationale for the boundaries of his scope of meaning, the reader has to make a choice between competing arguments of exegetes, arbitrarily.

${ }^{61}$ Levenson, Death and Resurrection, 126 
inquiry about the Patriarch's location. What is at stake, is his readiness to act upon a command from God (vv 1,11) and to face the human consequences (v 7)." ${ }^{\prime 2}$ Levenson's argument for expanded psychological openness and accountability is supported twice by Abraham's full physical compliance after answering "Ready (hinneni)" to God.

However, in Abraham's conversation with Isaac, his response "Ready (hinneni)" (v 7) again appears, but here Levenson admits that Abraham "is not at all ready to tell Isaac the blunt truth about the sacrifice he is prepared to carry out on God's instructions" [italics added]. ${ }^{63}$ Did Abraham pull back after expressing ready accountability to his son? Or is the scope of meaning for hinenni not as psychologically broad as Levenson had initially proposed ${ }^{64} \mathrm{~A}$ reader may wonder about the underlying hermeneutical principle that motivates Levenson to argue for a restriction of the scope of meaning for one term (nissa) and a broadening of the scope of meaning for another (hinneni).

In addition to semantic scope, literary form also elicits exegetical judgment.

Levenson illustrates how the structural "effect of the four designations of the person to be sacrificed is beautifully brought out in a famous midrash."

"Your son." He said to him, "I have two sons. Which son?" he answered him, "your favored one." He said to him, "Each is the favored one of his own mother." He replied, "the one whom you love." He said, "Is there a limit to the affections?" He

${ }^{62}$ Levenson, Death and Resurrection, 127

${ }^{63}$ Levenson, Death and Resurrection, 137.

${ }^{64}$ When Isaac is old and blind, this pattern of dialogue (Jacob: My father? Isaac: Here I am [hinneni], my son) is repeated. In that scenario, Jacob the son is inauthentic and Isaac is trusting and open, ready to act and face the consequences when he replies with hinneni. Gen 27:18. 
answered, "Isaac." And why did He not reveal it to him immediately? In order to make him more beloved to him and to give him a reward for each utterance. ${ }^{65}$

Levenson believes the Aqedah requires Abraham to place "obedience to God not above ethics, as Kierkegaard would have it, but above his love for Isaac — in some ways a more daunting task. ... As the midrash suggests, each of these terms underscores the preciousness of Isaac, the beloved son marked for sacrifice, and yet Abraham does not flinch but goes forth to slaughter the boy whose specialness has never been made so clear as it is at that moment." ${ }^{66}$ Abraham's paternal love for Isaac has just been heightened by the multiple designations and now that stirred up love is pitted against Abraham's fear of God. Levenson has linked the literary form of the text on the micro-hermeneutical level to an extra-biblical source of midrash interpretation then brings the reader to a theological conclusion about the nature of the test as the choice between Abraham's love for Isaac versus Abraham's obedience to God, a meso-hermeneutical proposition.

\section{Meso-Hermeneutic}

The preceding is one example of how Jon Levenson's expertise in the "'rewritten Bible' of Second Temple Judaism" provides a rich context for textual explorations at the meso-hermeneutical level. Utilizing “internal literary analysis, ancient near eastern parallels, and rabbinic and Christian midrash to develop a series of profound insights," 67

${ }^{65}$ Levenson, Death and Resurrection, 127.

${ }^{66}$ Levenson, Death and Resurrection, 128.

${ }^{67}$ David Blumenthal, "Jon Levenson, the Death and Resurrection of the Beloved Son," Revue des études juives 160, no. 1-2 (January 2001): 265. 
Levenson skillfully delves into intertextual analysis (Ex 22, Ex 34, and the prophets' horrified disavowals of child sacrifice), ${ }^{68}$ etiological hypotheses (Aqedah as etiology for animal substitution, eventual site of the Israelite Temple, common sayings), ${ }^{69}$ thematic development (Isaac, Joseph, and the Israelite nation experience chosenness and "firstborn status" as God's "absolute claim" by enduring a death-like ordeal), ${ }^{70}$ typology (Christian application to Jesus), ${ }^{71}$ and historical socio-political transformation (during the 2 nd cent B.C.E. the Aqedah was the definitive symbol of Abraham's life, connected to the paschal lamb, then to all lamb offerings; the self-sacrifice of Isaac became the Aqedah focus in the 1 st cent C. E., ${ }^{72}$ then was applied to Jesus by Christians with an anti-semitic twist"Paul's Jesus does not manifest Isaac. He supersedes him”³3).

Since one of the goals of meso-hermeneutical analysis is to analyze the logic and theological concepts behind the use of interpretive methods, two examples of Levenson's engagement with the historical critical method will be discussed. First, Levenson's primary hypothesis in the book The Death and Resurrection of the Beloved Son is that the

\footnotetext{
${ }^{68}$ Levenson, Death and Resurrection, 4-5.

${ }^{69}$ Levenson, Death and Resurrection, 111-124.

${ }^{70}$ Levenson, Death and Resurrection, 60.

${ }^{71}$ Levenson, Death and Resurrection, 213.

${ }^{72}$ Levenson, Death and Resurrection, 198-199.

${ }^{73}$ Levenson, Death and Resurrection, 213.
} 
"myth of the death (and often the resurrection as well) of the beloved son"74 remains a viable myth throughout Israel's history. His evidence includes the books of Jeremiah and Ezekiel in the 6th cent B.C.E. that denounce child sacrifice to YHWH in absolute terms. But Exod 12-13 which is dated to the P source in 5th cent B.C.E., and Christian materials in 1st cent C.E continue to refer to the theme of substitutionary firstborn sacrifice in the paschal lamb. For Levenson, this suggests the persistence, at least in concept, of the firstborn sacrifice. ${ }^{75}$

The possibility of incorrect source dating undermining Levenson's hypothesis is countered by canonical critique: "Even if $\mathrm{P}$ is dated earlier than the sources critical of the substitutionary etiology of the paschal lamb, the fact that Exodus 12-13 was preserved, included in the Pentateuch, and taken as normative in some sense in both Judaism and Christianity speaks to the same point: the mythic-ritual complex that I have been calling "child sacrifice" was never eradicated; it was only transformed." "ᄁ6 Both the historical critical method and canonical criticism are employed to ground his thesis. ${ }^{77}$

The second example addresses the fact that historical critical source explanations of the divine names in the Aqedah threaten its integrity as a narrative unit. The narrative

${ }^{74}$ Levenson, Death and Resurrection, 43.

${ }^{75}$ Levenson, Death and Resurrection, 43-45.

${ }^{76}$ Levenson, Death and Resurrection, 45.

${ }^{77}$ The exclusive use of the historical critical method for interpretation is a "fundamentalist denial of historical change" which ignores the multicontextuality of the Hebrew Bible by extreme reduction of the context to the historical one at the formation of the writing. Levenson insists that both the literary (or canonical) context as well as the entire tradition of the religious community including the reader's own religious experience must be taken into account. Levenson, Hebrew Bible, 4-5. 
is usually ascribed to the northern source called the Elohist (E) because Elohim is the initial designation of the divine tester. However, five times (vv 11, 15, 16, and two times in $\mathrm{v} 14$ ) the tetragam (YHWH) or J name presumably from the southern Judean tradition is also used. Historical critical scholars usually "excise the YHWHistic features" from the story in favor of the E source as original storyline. ${ }^{78}$ However, Levenson points to a theological paradox in the Aqedah, why would a northern source endorse a southern tradition? The phrase "God will see to the sheep" in verse 8 ties the theological significance of the sacrifice to the southern Judean temple site, but clearly employs the name Elohim. Thus, Levenson favors theological integrity over linguistic vivisection, "The classical source-critical assumption that the variations between YHWH and élohhim must be explained by the Documentary Hypothesis is, at least in this instance, much to be doubted. Rather than to eliminate the tetragrammaton from vv 11 and 14, it is preferable to retain it at the cost of the classical source-critical presupposition." ${ }^{\prime 9}$ In the end, Levenson tends to favor theological, canonical and sociological consistency over linguistic dating for meso-hermeneutical conclusions.

\section{Macro-Hermeneutic}

Macro-hermeneutics attempts to elucidate the philosophical concepts of the text. Because it is speculative to analyze a category that Levenson's book on the Aqedah does

\footnotetext{
3 (1988).

${ }^{78}$ See R. W. L. Moberly, “The Earliest Commentary on the Akedah,” Vetus Testamentum 38, no.

${ }^{79}$ Levenson, Death and Resurrection, 122.
} 
not address directly, this section of analysis must remain tentative. At the same time, all interpreters hold philosophical assumptions albeit with varying degrees of self-awareness or acknowledgement. Scholarly and religious communities must share a nest of presuppositions in order to communicate ${ }^{80}$ and theologians implicitly hold a theocentric metaphysics that can be referred to as a world of meaning above the text.

Starting with macro-methodology, Levenson is not interested in abstract philosophical harmonization of contradictory Biblical texts. He is interested in rational explanations of shocking paradoxes, especially if it faithfully preserves the particularities of the text. Ezekiel 20:25-26 refers to God giving bad laws, namely, requiring firstborn human sacrifices. Levenson wryly comments that this text has "most exegetes running for cover." 81 In contrast, he boldly accepts the literal interpretation as the true intention of the verse. Explanatory proposals of receptive misunderstanding or corrupted hermeneutics by the addressed community are dismissed by Levenson as looking for answers in the wrong

${ }^{80}$ Collective habits of mind bind a community of scholars or scientists together. They may be philosophical concepts, deeply held values, prevailing theories, or procedures. It is the only way they can recognize who is in the community and who is not, to evaluate new information, to cross-communicate meaningfully to each other. Howard Margolis, Paradigms and Barriers: How Habits of Mind Govern Scientific Beliefs (Chicago, IL: University of Chicago Press, 1993), 23.

${ }^{81}$ Levenson, Death and Resurrection, 6. 
direction of the audience. There is no escaping the literal truth, "God did indeed ordain child sacrifice," Levenson asserts unequivocally. ${ }^{82}$

For him, this verse must be resolved at its origin. "The only explanation for this that preserves the continuity of YHWH's will is the one that Ezekiel, in fact, offers: YHWH's command and Israel's obedience to it were the way of punishment, a means to bring about the death of those who had turned away from the means to abundant life," (emphasis added). ${ }^{83}$ Levenson's proposal assumes continuity in the Absolute will. This seems to be one presuppositional concept that anchors his macro-hermeneutical harmonization without altering the plain meaning of the text.

Divine continuity, however, is not to be confused with uniformity. Levenson believes the Passover ritual reveals that YHWH has a darker side to avoid. "The Destroyer is YHWH in his aspect of slayer of the first-born son. This is not an aspect of the Deity that the biblical tradition is inclined to celebrate, and for obvious reasons. ... In the P theology, Passover is not only the story of YHWH's victory over Pharaoh. It is also the story of YHWH's victory over himself, and it stands as a continual reminder of just how narrow that victory was: but for the blood of the lamb, the Israelites would have suffered the same catastrophe as the Egyptians." ${ }^{\prime 44}$ Levenson accepts both aspects of the divine, as a firstborn slayer and a firstborn redeemer to accentuate the crucial partnership

\footnotetext{
${ }^{82}$ Levenson, Death and Resurrection, 6.

${ }^{83}$ Levenson, Death and Resurrection, 8.

${ }^{84}$ Levenson, Death and Resurrection, 46.
} 
between divine and human action that propels Israel's history forward. Which side of God will be revealed, is contingent on human choices.

Levenson's macro-hermeneutical theistic principles are (1) continuity in the divine will, (2) opposite aspects in the use of divine power, and (3) correlation of human and divine actions in history. If these concepts are applied to the Akedah, unity in divine will, diversity in divine action, and divine responsiveness in relation to humans become the foundational presuppositions for the divine tester in the Akedah. The divine intentionality embedded in the test could be fruitfully unpacked through such lenses if the cycle of micro-meso-macro-hermeneutical analysis were embarked on again.

The main interpretive focus of Levenson's book is in illuminating the mesohermeneutical level of the ancient world behind the text and in front of the text through the historical period of the Hebrew Bible and the New Testament. Our next theologian, Fretheim, is complementary to Levenson for Fretheim focuses on the present needs of the modern reader in front of the text and the implications of the text on traditional theistic presuppositions above the text. The existential approach of Fretheim brings the personal world of the interpreter into the interpretation of the Aqedah.

\section{Fretheim and the Existential Approach}

Existentialism is not a formal method of interpretation like the historical critical method referred to above, but a philosophical mode of accessing the meaning of the text by internalizing it in a personal, intensely authoritative manner that penetrates the reader 
in the present.$^{85}$ Reading the text becomes a compelling event that confronts and calls on the reader to individuate in the present by making an authentic decision. Historically, existentialism was a reaction against subject-object dualism, reason as an absolute norm, human objectivity, distancing as the necessary stance for understanding, and philosophical academics as the arbiters of truth. ${ }^{86}$ In existentialism, authenticity is the norm of truth and commitment is the fruit. ${ }^{87}$

Søren Kierkegaard, as a Christian, championed authenticity as an inner subjective and individual response that refused to cave into communal norms but anchored the self in the infinite call of the Divine. ${ }^{88} \mathrm{He}$ believed Christian authenticity or being "true to oneself" was not synonymous with solipsism for the believer acknowledges an absolute

${ }^{85}$ Thiselton, New Horizons, 563-565. "Historically, the roots of existential philosophy can be traced to the nineteenth-century writings of Soren Kierkegaard, Friedrich Nietzsche, and Fyodor Dostoyevsky. Central to the work of these figures was an emphasis on the existing individual, and a call for consideration of man in its concrete situation, including his culture, history, relations with others, and above all, the meaning of personal existence." David Stewart and Algus Mickunas, Exploring Phenomenology: A Guide to the Field and Its Literature (Athens, OH: Ohio University Press, 1990), 63.

86 "This temper [existential mood] can be described as a reaction against the static, the abstract, the purely rational, the merely irrational, in favor of the dynamic and concrete personal involvement and 'engagement,' action, choice and commitment, the distinction between 'authentic' and 'inauthentic' existence, and the actual situation of the existential subject as the starting point of thought." The Worlds of Existentialism: A Critical Reader, ed. Maurice Friedman (New York, NY: Random House, 1964), 3-9.

${ }^{87}$ Heidegger explained authenticity as a resolute owning of one's potential to become uniquely itself, recognition of death as inevitable heightens the need to be passionately self-aware in the present. "Anticipation reveals to Dasein its lostness in the they-self, and brings it face to face with the possibility to be itself, primarily unsupported by concerned taking care of things, but to be itself in passionate anxious freedom toward death which is free of the illusions of the they, factical, and certain of itself.'[sic] Martin Heidegger, Being and Time, 245.

${ }^{88}$ Kierkegaard referred to societal norms as the "ethical" or "universal," and contrasted the mores of the crowd vs the inner subjective commitment of the individual. According to Kierkegaard, an authentic Christian was one who chose to live in direct, unmediated responsibility to his/her singular God.

Kierkegaard, Fear and Trembling, 83-88. 
origin and source of meaning outside themselves in God. ${ }^{89}$ Thus Kierkegaard's definition of authenticity was not rooted in self, but in relation..$^{90}$ Abraham is silent in the Aqedah test because trusting commitment transcends man-made rules and arises from the deepest interior of a human being like love, it is an inexplicable gift beyond and above rationality. ${ }^{91}$ Kierkegaard's final conclusion on the Aqedah is: "So either there is a paradox, that the single individual as the particular stands in an absolute relation to the absolute, or Abraham is done for. ${ }^{92}$

Terence Fretheim resonates with Kierkegaard in his existential treatment of the Aqedah and enlarges it. Fretheim does not limit himself to the authentic response of the human being Abraham to the divine test, but also considers God as a subjective being, engaged and deeply affected by the Aqedah. Fretheim believes divine authenticity is also at stake in this test. Kierkegaard's line of testing between God and Abraham becomes

${ }^{89}$ In contrast to Kierkegaard's theistic grounding for authenticity, Martin Heidegger, Friedrich Nietzsche, and Jean-Paul Sartre chose to accept human finiteness and temporality, freedom to express one's inherent nature, or the freedom to choose, as nontheistic themes for authenticity. Radical human freedom is championed by Sartre's famous assertion, "existence precedes essence." Sartre states, "What do we mean here by 'existence precedes essence?' We mean that man first exists: he materializes in the world, encounters himself, and only afterwards, defines himself. . . he will be what he makes of himself." JeanPaul Sartre, Existentialism Is a Humanism, ed. John Kulka, trans. Carol Macomber (New Haven, CT: Yale University Press, 2007), 20, 22.

90 "The paradox can also be put by saying that there is an absolute duty to God; for in this tie of obligation the individual relates himself absolutely, as the single individual, to the absolute." Kierkegaard, Fear and Trembling, 98.

91 "So Abraham's story contains a teleological suspension of the ethical. He has, as the single individual, become higher than the universal. ... he who walks the narrow path of faith no one can advise, no one can understand it. Faith is a marvel, and yet no human being is excluded from it; for that in which all human life is united is passion, and faith is a passion." Kierkegaard, Fear and Trembling, 95.

${ }^{92}$ Kierkegaard, Fear and Trembling, 144. 
triangulated by Fretheim in a sense, suspending both covenant participants as objects of the same test. "The test no longer involves simply Abraham's trust in God, it has become a test of God's faithfulness in providing." ${ }^{93}$ The reader is drawn centripetally into the plot, captured by the existential dilemmas brought up by Fretheim's exploration.

\section{Biography of Terence Fretheim}

Terence Fretheim is an emeritus professor at Luther Seminary in St. Paul, Minnesota. His previous roles at Luther Seminary included dean of academic affairs (1978-1988), chair of Old Testament Department (1977-1978), chair of curriculum committee (1976-1977), Professor of Old Testament since 1978, Assistant professor of Old Testament (1968-1978), and teaching fellow in Greek (1958-1960). He has also taught Old Testament at Augsburg College and Seminary (1961-1963) and at Princeton Theological Seminary (1966-1967).

Fretheim is a recipient of the Fulbright Scholarship, the Lutheran Brotherhood Seminary Graduate Scholarship, the Martin Luther Scholarship, the Fredrik A. Schiotz Fellowship Award, and the ATS Scholarship for Theological Research. He obtained his M.Div. from Luther Seminary (1960) and his Th.D. is from Princeton Seminary (1967). Among his numerous publications are The Pentateuch (Abdingdon, 1996); Proclamation (Fortress, 1997); The Bible as Word of God in a Postmodern Era (Fortress, 1998, with K. Froehlich); In God's Image: A Study of Genesis (Augsburg, 1999); A Theological

\footnotetext{
${ }^{93}$ Fretheim, Abraham, 133.
} 
Introduction to the Old Testament (Abingdon, 1999); Abraham: Journeys of Family and Faith (University of South Carolina Press, 2007).

As an author, Fretheim writes for the reader. They are to be challenged, invited and intrigued by the dialogical questions that Fretheim draws from the biblical text. This existential approach makes his work engaging and provocative. The image of God that Fretheim believes is supported by the Hebrew Bible is existential in that God voluntarily opens himself to risk, limits his omnipowers in order to share power with his creation and engages in authentic relationships that require self-limitation and being affected by the free choices of his creatures. ${ }^{94}$ In short, "God makes God's self vulnerable." ${ }^{95}$ This divine self-limitation, the voluntary sacrifice of one's omnipowers for authentic interaction with his creatures is one of the keys to Fretheim's interpretation of the Aqedah.

\section{Fretheim's Interpretation of the Aqedah}

Fretheim's interpretation of the Aqedah nests within the larger themes of the universal creator who wants to bless the whole world and God's promissory role of love and faithfulness toward the inhabitants of the earth through Abraham's family line. The

94 "Moreover, any relationship of integrity will entail a sharing of power. Each party to the relationship must give up any monopoly on power for the sake of the relationship. Neither party to the relationship can be overwhelmed for the relationship to be a true one. For the sake of the relationship, God gives up the exercise of some power. This will in turn qualify any talk about divine control or divine sovereignty. Total control of the other in a relationship is no relationship of any integrity." Terence Fretheim, The Suffering of God: An Old Testament Perspective, Overtures to Biblical Theology (Philadelphia, PA: Fortress Press, 1984), 37.

${ }^{95}$ Terence Fretheim, Creation Untamed: The Bible, God and Natural Disasters (Grand Rapids, MI: Baker Academic, 2010), 133, 58, 29; Terence Fretheim, God and the World in the Old Testament: A Relational Theology of Creation (Nashville, TN: Abingdon Publishing, 2005), 269-284. 
patriarchal narratives (Gen 12-50) are connected to primeval texts (Gen 1-11) by the "fulcrum text" of 12:1-3 which holds both the blessed "universal frame of reference" and the promise of greatness. ${ }^{96}$ But God doesn't restrict his blessings to one family.

God's continuing independent activity on and for others outside the elect family in the promised land is amply represented by the stories of Melchizedek, Hagar and Abimelech. It is unmistakably clear that these and other characters who are "unchosen" have "experienced God, even if they have not realized that it was God." ${ }^{97}$ At the same time, by working with Abraham's finite and imperfect family line, God "reveals a deep vulnerability, for it links God with people whose reputations are not stellar and opens God's ways in the world to sharp criticism."98

One event open to moral criticism is the final test of Abraham. Fretheim is quick to make a distinction between morality and religion in this test. He writes, "It is striking that God's testing of Abraham (Genesis 22) does not entail a moral issue; rather, a specifically religious issue of trust is raised. Indeed, it may be claimed (at least in modern

\footnotetext{
${ }^{96}$ Fretheim, Abraham, 5.

${ }^{97}$ Fretheim, Abraham, 6.

${ }^{98}$ Fretheim, Abraham, 13.
} 
terms) that God calls upon Abraham to violate a certain 'moral value' to demonstrate a religious value." ${ }^{99}$

According to Fretheim, the religious value of the test is to measure Abraham's faithfulness (Genesis 22:15-19) after he has received the fulfillment of the promise of progeny. Thus "the test is focused precisely on the point of fulfillment, namely, Isaac."100 Had Abraham not shown continuing faithfulness, "God's promises and purposes for the world would not finally be stymied by Abraham's resistance" but Abraham's resistance would have cut himself out of the blessing of participation in God's plan. ${ }^{101}$

Abraham's demonstrated obedience during the test becomes incorporated into the promise as a motivating factor for God's unprecedented swearing of the covenant "by the divine self," an action prefigured in Genesis 15 where God enacted a "self-binding ritual" on the covenant. ${ }^{102}$ Fretheim ties it all together by explaining "the promise takes shape in the actual lives of people, whose own words and deeds are centrally involved in its transmission. ... The continuing transmission of the promise is placed in the hands of

\footnotetext{
${ }^{99}$ Fretheim, Abraham, 13.

${ }^{100}$ Fretheim, Abraham, 139.

${ }^{101}$ Fretheim, Abraham, 139.

${ }^{102}$ Fretheim, Abraham, 138.
} 
those who are faithful, and the importance of their witness ought not to be discounted."103 God and man are linked by a faith-filled relationship with tangible consequences.

\section{Analysis of Fretheim's Hermeneutics}

\section{Micro-Hermeneutic}

Fretheim's close reading of the Aqedah starts by acknowledging the shift of scholarly interest from the text's historical-critical composition to issues of literary criticism. He acknowledges, "Genesis consists of traditions from various historical periods, but little consensus exists regarding the way in which they were brought together in their present form." 104 In regard to the Abrahamic stories, "P is often understood to be the redactor of the Abrahamic cycle, drawing upon JE and other materials and putting them together essentially as we now have them. "105 But now, "new strategies focus on issues of literary criticism rather than literary history." 106

Literary criticism turns on "matters such as language and style, surface and deep structures of the text, rhetorical devices, narratological features such as repetition, irony, plot, depiction of characters, and especially point of view (of the narrator and the characters). These newer literary approaches have contributed significantly to our

\footnotetext{
${ }^{103}$ Fretheim, Abraham, 136.

${ }^{104}$ Fretheim, Abraham, 19

${ }^{105}$ Fretheim, Abraham, 20.

${ }^{106}$ Fretheim, Abraham, 20
} 
understanding of these texts." ${ }^{107}$ Fretheim's literary comments of the world in the text pair textual details with exegetical discussions of their significance in brief readable sections, for example, the phrase after these things elicits a quick review of the previous nature of the relationship between God and Abraham in order to set up a discussion of why God felt it necessary to test Abraham. ${ }^{108}$ Other literary details discussed are the five sets of phrases repeated in the pericope, ${ }^{109}$ the structural center of the story being Abraham's response of "Here I am, my son" to Isaac's call, ${ }^{110}$ and the noted silence of the narrator in regard to Abraham and Isaac's inner motives. Regarding the absence of psychological and emotive details, Fretheim advises, "given the utter lack of interest in the motives of Abraham on the part of the narrator, readers should accept the force of his statements unless and until the narrative gives a clue to the contrary."111

Narrative dissonances are also explored, such as the haunting aftermath of the test where "the return of Isaac with his father is not reported in verse 19 (though Abraham

${ }^{107}$ Fretheim, Abraham, 20.

108 They are (1) parallels between the initial call and present test command, (2) the ups and downs of their relational journey together, exhibiting both deep faith and mistrust, (3) the parallels and contrasts with the banishment of Ishmael that precedes this test. Fretheim, Abraham, 127-128.

109 The phrases are: (1) "the mountain I will show you" (Gen 22:2: cf.12:1), (2) "Your son, your only son" (vv. 2, 12, 16), (3) "seeing" ("lifts up his eyes" vv. 4, 13, ra'ah vv. 4, 8, 13, 14), (4) "Here I am" (vv. 1, 7, 11); (5) "The two of them walked on together" (vv. 5,8), Fretheim, Abraham, 129-130.

${ }^{110}$ Fretheim, Abraham, 130. Fretheim describes Abraham's response to Isaac's question this way: “Abraham's response to Isaac does not tell him everything (what God has commanded) —in any case, he does not know everything. But he does answer Isaac's question directly and conveys what he believes is the truth about Isaac's future: God will provide." Fretheim, Abraham, 131.

${ }^{111}$ Fretheim, Abraham, 131. 
had so assured his servants in verse 5)." ${ }^{112}$ Fretheim's exegetical discussions set the groundwork for the theology on the next level of meso-hermeneutics where he examines the narrative from the point of view of the narrator, Abraham, God, and the imagined reader. ${ }^{113}$

\section{Meso-Hermeneutic}

Since the text functions as a biblical window into past religious practices on the meso-hermeneutical level, Fretheim calls attention to the fact that the family-life context of the Abrahamic stories is notable for the absence of religious institutions (central temple, dietary regulations, priesthood, Sabbath) that were so important to later Israel. Abraham's world of meaning behind the text is a pre-cultic world.

The Genesis texts exhibit no concern whatsoever that Abraham, the founder of Israelite faith, is so nonobservant regarding such practices. . . his worshipful activity presupposes practices in place before his call. His journey through the land seems not to be associated with the founding of sanctuaries, but, rather, building altars at known sacred places (without personnel or buildings), marked by trees $(12: 6-7 ; 13: 18 ; 21: 33$; cf. 35:4-Moreh is probably a well-known site), pillars or stones $(28: 18,22)$. The later association of these natural markers with idolatry (cf. Exod. 23:24; 34:13; Deut. $12: 2 ; 16: 21)$ is not evident in these texts. ${ }^{114}$

It is in this context that Fretheim revisits Levenson's reference to Isaac as a "burnt offering," the ram as a "substitute" sacrifice, and the test as a first-born son offering

\footnotetext{
112 Fretheim, Abraham, 132.

${ }^{113}$ Fretheim, Abraham, 132-139.

${ }^{114}$ Fretheim, Abraham, 27.
} 
"within the context of the sacrificial system." 115 Levenson had argued, "“in the biblical text, sacrifice is not deemed unethical or irrational' and so it requires no more an act of faith to adhere to such demands than to ethical demands." 116 While Fretheim concurs that within the historical context of Abraham his intent to sacrifice Isaac may not have been unusual, Fretheim insists present evaluative judgments still ought to be made on patriarchal practices. ${ }^{117}$ Fretheim understands other compassionate minded interpreters may be tempted to turn this "story of sheer horror"118 into a spiritual metaphor in order to evade such judgments, ${ }^{119}$ but he feels those attempts end up trivializing the experience of the sacrificial victim. He asks, "Whatever Abraham's (and God's) intent, is it not likely that Isaac was traumatized by the threat of imminent and violent death at the hands of his

${ }^{115}$ Fretheim, Abraham, 124.

${ }^{116}$ Fretheim, Abraham, 125. Levenson is adamant that Abraham is not an unethical child abuser and believes "it is a symptom of acute myopia and mind-numbing parochialism to think that this must also have been the case in a society that practiced sacrifice (even, on occasion and for a while, child sacrifice) and did not confuse it with murder.” Jon Levenson, "Abusing Abraham: Traditions, Religious Histories, and Modern Misinterpretations," Judaism 43, no. 3 (Summer 1998), 271.

${ }^{117}$ Fretheim, Abraham, 125.

${ }^{118}$ Fretheim, Abraham, 127.

${ }^{119} \mathrm{He}$ cites Levenson and Moberly's metaphorical understandings: the sacrificial death is symbolic for the son returns alive and this is a metaphor for Israel who is the one to make the sacrifice (as Abraham) and to be the sacrifice (as Isaac). Fretheim, Abraham, 126. 
father?" 120 In conclusion, "The text does not finally enable one to sit comfortably with the obvious abuse that Isaac undergoes," ${ }^{121}$ the plight of the son must not be overlooked.

Fretheim reminds readers that testing is not new to the patriarch Abraham. The Aqedah is not an isolated event but instead, a window itself that reveals Abraham life has been all along a series of challenges. Fretheim holds up testing as a common facet of all significant relationships:

Testing must be understood relationally rather than legalistically; it is characteristic of all relationships of consequence. ... What constitutes testing in one situation or another will be determined by the nature of the relationship and the expectations the parties have for it. As a relationship matures and trust levels are built up, faithful responses to the testing of the relational bond will tend to become second nature. And yet, there may be moments, even in a mature relationship, where sharp, even absurd moments of testing present themselves. This may be the kind of moment with which Abraham is faced. ${ }^{122}$

Notice how the reader is invited to appropriate the Aqedah by acknowledging that testing is a common thread of relationships in everyone's life, this is existential application at its best. Fretheim then addresses the reader in front of the text who has now identified with Abraham, “Abraham, and the readers, might learn from such experiences that receiving promises from God does not entail being protected from times where those

${ }^{120}$ Fretheim, Abraham, 126.

${ }^{121}$ Fretheim, Abraham, 132; Because this issue remains pertinent to modern day concerns, it affects the reading of this text by contemporary audiences. "Is God (and by virtue of his response, Abraham) guilty of child abuse in this text? There is no escaping the question, and it raises the issue as to the continuing value of this text." Fretheim, "God, Abraham and the Abuse of Isaac," 49.

${ }^{122}$ Fretheim, Abraham, 132. 
promises are called into question. Will God be trusted in such moments?"123 In this way the reader is invited to make an existential commitment in the present, to enter the modeof-being that the text projects for its audience.

\section{Macro-Hermeneutic}

On the macro hermeneutical level, Fretheim probes the divine Tester's motive above the text for testing Abraham. As he sees it, the Aqedah is to satisfy a vital question God has, ${ }^{124}$ "The question for God is: Is Abraham the faithful one who can in fact carry that purpose along? Or does God need to take some other course of action, perhaps even look for someone who would be more faithful? The faithfulness of Abraham is not an option for God and for God's purposes in the world." ${ }^{125}$

Understandably, this view of divine knowledge contrasts with the traditional view of omniscience never needing to question or test. ${ }^{126}$ But Fretheim's close reading of the text of the Aqedah has led him to conclude, "The only one said to learn anything from the test is God. The climactic verse 12 states this clearly: 'Now I know.' . . . The issue here is

${ }^{123}$ Fretheim, Abraham, 132-133.

${ }^{124}$ Here, Fretheim takes the test as a way to fill what is missing in divine knowledge. The test is like a final entrance exam to go to the next level of increased responsibility.

125 Fretheim, Abraham, 136.

${ }^{126}$ Fretheim recognizes that "The normally unexamined assumption is that all such divine questions are rhetorical, asked by God for effect in one situation or another, and not 'real' questions seeking to elicit an answer. ... Y Yet, as we have seen, metaphoric language must have some reasonable relationship to reality. . . . by the questions, God indicates that the divine moves into a future which is as yet unknown; there can be no certainty in respect to what will happen as God pursues this new direction. The clear implication is that the future will bring new knowledge for God, as well as for the people; this will affect what God says and does." Fretheim, The Suffering of God, 45-59. 
not what God teaches Abraham, but what God learns about Abraham."127 Fretheim does not relegate this phrase to anthropomorphism and cites other scholars who have arrived at the same conclusion. Fretheim quotes Brueggemann who writes that the Aqedah "is not a game with God; God genuinely does not know. The flow of the narrative accomplishes something in the awareness of God. He did not know. Now he knows." ${ }^{28}$ Crenshaw is also quoted: "The fundamental assumption lying behind divine testing is that God lacks a certain kind of knowledge, that is precisely how men and women will act in trying circumstances. Of course, such ignorance arises from human freedom, which is itself a gift from the transcendent one. Therefore, the divine act of self-limitation has created the necessity for such testing." ${ }^{29}$ Fretheim presses the point home by considering the moral implications of the alternative, "If God knew absolutely or precisely how Abraham would respond to the test, then God was just playing with Abraham."130

For Fretheim the text reveals a God above the text, who is omniscient and omnipotent but may voluntarily self-limit his omni-powers and his absolute freedom, for the sake of genuinely relating to others with whom he graciously shares power, knowledge and freedom. ${ }^{131}$ This is especially true for those in the covenant for He intends

${ }^{127}$ Fretheim, Abraham, 136.

${ }^{128}$ Fretheim, Abraham, 136; Walter Brueggemann, Genesis, Interpretation: A Bible Commentary for Teaching and Preaching (Louisville, KY: Westminster John Knox Press, 2010), 187.

${ }^{129}$ Fretheim, Abraham, 136; James Crenshaw, A Whirlpool of Torment (Philadelphia: Fortress Press, 1984), 2. 139.

${ }^{130}$ Fretheim, Abraham, 136. "God is not so in control of the situation that it ceases to be a test,"

131 “As in any relationship of integrity, God will have to give up some things for the sake of the 
to be faithful to it. In the Aqedah when Abraham puts his complete trust in divine providence "it puts God on the spot. The test of Abraham has now become a test for God." ${ }_{132}$ The agency of Abraham who has the power through his choices to affect God reveals the anthropological presuppositions below the text regarding creation.

What started out as a test of Abraham's obedience has now expanded into a test of God's providence. ${ }^{133}$ The conclusion of the test is the testimony that both parties were found faithful, not just the human participants. It is clear "God has passed the test; God has responded to Abraham's trust and kept the divine commitment to Abraham. May the praise be also due to what God has put the divine self through? For the sake of the future of the divine purposes, God has had to pass though this valley of endangered promises." 134

In brief, Fretheim's macro-hermeneutical principles include the conviction that divine omnipotence and omniscience are self-limited for authentic relationships to His creation and in timely response to his creature's choices, God knowledge changes - the

relationship. Thus, God will have to give up some freedom. Any commitment or promise within a relationship entails a limitation of freedom. By such actions, God has decisively limited the options God has for speaking and acting. God has exercised divine freedom in the making of such promises in the first place. But in having freely made such promises, thereafter God's freedom is truly limited by those promises." Fretheim, The Suffering of God, 36.

${ }^{132}$ Fretheim, Abraham, 134.

${ }^{133}$ Fretheim goes on to speculate, "If God does not provide, and Isaac is sacrificed, then Abraham's trust that God will provide is placed in severe jeopardy. Such an eventuality would constitute another kind of test for Abraham, a test at a much deeper level than the one that initiated this journey." Fretheim, Abraham, 134.

${ }^{134}$ Fretheim, Abraham, 137. 
future has changed. The last word in the test of the Aqedah is not human, but reveals a deeper divine existential commitment: "God swears by the divine self for the first time in the narrative, though it recalls the self-binding ritual of God in Genesis 15." ${ }^{35}$ Fretheim makes it clear that "human activity can shape the future, though it cannot finally stymie God's purposes." ${ }^{136}$

\section{Summary}

Levenson's and Fretheim's interpretive works on the Aqedah are brilliant and insightful. On the micro-hermeneutical level both acknowledge historical-critical points but focus their exegetical skill on the literary critique of the text in final form. The meaning in the text's linguistic details are highlighted, though some minor exegetical disagreements over nuance, scope of meaning, and significance are settled in a fragmentary manner.

At the meso-hermeneutical level a predictable divergence stemming from their interpretive methodology is revealed. Levenson's socio-historical-critical skills masterfully excavate the world behind the text to trace the eventual historical sublimation of the persistent child sacrifice motif as first fruit offering in front of the text for Christians on the crucifixion of Jesus Christ. Fretheim's existential approach pulls the contemporary reader in front of the text into identifying with the real-life dilemmas and challenges of the characters in the Aqedah. Thus, Levenson attempts to normalize the

\footnotetext{
${ }^{135}$ Fretheim, Abraham, 138.

${ }^{136}$ Fretheim, Abraham, 140.
} 
Aqedah by placing it in an early cultic setting which is familiar with child sacrifice as first fruit donations; Fretheim's interpretation of the Aqedah remains disturbing for the abuse of Isaac and the use of divine testing as necessary to inform God on whether man can be trusted.

The implied macro-hermeneutical tenets of Levenson were (1) continuity in the divine will, (2) opposite aspects of the use of divine power, (3) correlation of human and divine actions in human history. Fretheim's tenets were (1) self-limitation of divine omniscience and omnipotence for authentic relationship, (2) correlation of human and divine actions in shaping a future, but (3) divine purposes cannot be thwarted. Both focused on theocentric meanings above the text while recognizing the same tenet for anthropological meaning below the text - that of human agency impacting God.

\section{Conclusion}

The filter of micro, meso, and macro-hermeneutical levels assists in critically comparing Levenson's and Fretheim's interpretive studies of the Aqedah because it differentiates between their exegetical, theological and philosophical findings. ${ }^{137}$ As we have seen, most scholars and commentators intermingle hermeneutical levels together as they progress through the text verse by verse. This method of arguing on multiple levels while inching forward inevitably supports the interpreter's biases because it allows the interpreter to emphasize and trace preferred conceptual threads vertically through interpretations.

${ }^{137}$ This fulfills one goal of hermeneutics which is to find a fair and effective method of comparing 
multiple hermeneutic levels, buttressing favored viewpoints with depth. Interpreters may dismiss opposing viewpoints as less grounded ${ }^{138}$ and gloss over textual ambiguity in order to convince the reader to their own stance. ${ }^{139}$ Thus, the vertical model of interpretation forces the reader to read through multiple works of interpretation to gain exposure to the wider range of meanings in the text.

If the text is unpacked through the micro-meso-macro hermeneutical levels one level at a time, this allows (1) the richness and nuances of the whole text to be heard at each level, possibly offsetting the agenda of any one interpreter, ${ }^{140}(2)$ the whole text to steer the study by allocating appropriate weight to its constituent parts through a careful analysis of the text's inherent literary structure, (3) the whole text to norm the conclusions at each hermeneutical level by the criteria of internal coherence and (4) the reader to be able to critique a proposed hypothesis from the conclusions of the other hermeneutical level of analysis. This is not advocating for a flat horizontal model ${ }^{141}$ but a graduating

\footnotetext{
${ }^{138}$ Interpreters commonly argue for their own viewpoint against others, amassing their case for a reductive singular conclusion. In hermeneutics, a different approach is recommended. Bridge-building between opposing points of view leads to understanding the underlying motives and journeys they represent. This is an important facet of hermeneutics as the science of understanding. This doesn't require adopting or relinquishing one's own stance, thought it may lead to that, it means deeper understanding of the reasons why other viewpoints exist is a worthwhile goal. Thiselton, Hermeneutics, 6 .

${ }^{139}$ Ambiguity in the text may even be theologically purposeful. Alter specifically mentions two characteristics of purposeful ambiguity in narratives - when the text exhibits selective reticence or a sudden breaking off of dialogue. Both of these are found in the Aqedah. Why would ambiguity be purposeful? It may be that "these ancient writers, like later ones, wanted to fashion a literary form that might embrace the abiding complexity of their subjects." Alter, The Art of Biblical Narrative, 153-154.

${ }^{140}$ The whole text as used here refers to the broad, not the exhaustive aspect of the text.

${ }^{141}$ A purely horizontal model is impossible for the micro-meso-macro hermeneutical levels are inherently interdependent and can only be isolated by willful blindness to the inescapable existence of the other levels.
} 
spiral model that works through the whole text on each hermeneutical level, building on the findings of each level as it continues with anticipation of possible meanings going forward with reflection on past understandings already encountered. ${ }^{142}$

In addition to each hermeneutical level, as we have seen in our analysis of Levenson's and Fretheim's interpretations of the Aqedah, the perceived worlds of meaning in, behind, in front of, above and below the text are used to fill in perceived gaps of the text. ${ }^{143}$ This happens intuitively in constructing human understanding but recognizing these implicit processes and clarifying them is a worthy hermeneutical goal. A schematic attempt to combine the three hermeneutical levels of micro-meso-macro hermeneutics to the five worlds of meaning in-behind-in front of-above-below the text and norm the process by the biblical text will be proposed in the following chapter.

\footnotetext{
${ }^{142}$ This is how human speech also works. The speaker and listener both anticipate a cloud of potential direction for future meaning and follow the path of spoken vocabulary through it while continually integrating the next word with already spoken words in order to construct full understanding. If confusion or ambiguity is encountered, careful re-tracing of the hermeneutical path already traversed (the previous loops) is usually the first step undertaken.

${ }^{143}$ For instance, we recognize that Isaac's question regarding the whereabouts of the lamb implies that he was familiar with animal sacrifices and had not been informed by Abraham that this pending sacrifice was to be any different. This meaning is from the world of the narrative in the text because it is conveyed as a trusting question from son to father.
} 


\title{
CHAPTER 3
}

\section{A MODEL AND A MICRO-HERMENEUTICAL ANALYSIS \\ FOR THE AQEDAH TEST}

\begin{abstract}
Introduction
In this chapter the initial outline of a hermeneutic model will be proposed that incorporates the text as the norming long axis for the three hermeneutical levels and the five worlds of meaning. This model will be tested by practical application to the Aqedah at the micro-hermeneutical level through the historical-grammatical-literary method. The findings will then be summarized and evaluated for faithfulness to the text, hermeneutic breadth and depth, and possible new insights.
\end{abstract}

\section{A Model Hermeneutic}

The model of a hermeneutical circle conveys the recognition that the interpretation of a text requires both inductive and deductive reasoning on how the parts relate to the whole. ${ }^{1}$ This means that understanding is enhanced when a text is analyzed

\footnotetext{
${ }^{1}$ Understanding speech as parts related to the whole was first attributed to Socrates: "Every speech must be put together like a living creature, with a body of its own; it must be neither without head nor without legs; and it must have a middle and extremities that are fitting both to one another and to the whole work." Plato, Phaedrus, trans. James H. Nichols, Jr., (Ithaca, NY: Cornell University Press, 1998), 264. Heinrich Bullinger was one of the first to grasp the hermeneutical circle concept by suggesting the details of a written text were better understood if the reader first grasped where the argument was leading. Anthony Thiselton, New Horizons, 194-195. Inductive and deductive reasoning in theology is discussed by Grant Osborne in The Hermeneutical Spiral, 385-386.
} 
(1) in relation to its literary context, ${ }^{2}(2)$ in relation to the pre-conceptions of the reader from outside the text, ${ }^{3}(3)$ in relation to the reader's existential world ${ }^{4}(4)$ in relation to the historical consciousness of the reader, ${ }^{5}$ and (5) in relation to the reader's projected hypothesis for understanding. ${ }^{6}$ Since the temporality of the interpreter (points $2,3,4 \& 5$ ) is assumed in the process of understanding, the model of a hermeneutical circle is better

${ }^{2}$ James Barr, The Semantics of Biblical Language (Eugene, OR: Wipf \& Stock Publishers, 2004), 139; George W. Reid, ed., Understanding Scripture: An Adventist Approach, Biblical Research Institute Studies, vol. 1 (Hagerstown, MD: Review and Herald Publishing Association, 2005), 117-118; Osborne, The Hermeneutical Spiral, 94; Benedictus de Spinoza, Theological-Political Treatise, 86-104.

${ }^{3}$ Chladenius recognized a variety of viewpoints (Sehe-Punkt) was inevitably brought by interpreters themselves: "Different people perceive that which happens in the world differently. . . It is generally accepted that there can be only one correct representation for each object and that if there are some differences in description, then one must be completely right and the other completely wrong. This principle is not in accordance with other general truths or with the more exact perceptions of our soul." Johann Martin Chladenius, "Introduction to the Correct Interpretation of Reasonable Discourses and Writings," in The Hermeneutics Reader, ed. Kurth Mueller-Vollmer (New York, NY: Continuum, 1990), 65. Schleiermacher found that some pre-understanding was necessary for true understanding, for understanding "presupposes a familiarity with both the contents and the language of the text. Assuming such familiarity, difficulties with particular passages of a text arise only because the easier ones have not been understood." Friedrich D. E. Schleiermacher from "Compendium of 1819" in The Hermeneutics Reader, 73.

${ }^{4}$ Heidegger saw hermeneutics as the larger disclosure of the existential reality of Being-in-theWorld: "In every understanding of the world, existence is understood with it, and vice versa." Martin Heidegger, Being and Time, 142.

${ }^{5}$ Gadamer defined historical consciousness to be the self-awareness of our historical situation and traditions. This recognition of pre-existing prejudices, biases, and desires comprises one's "horizon." This horizon is the "range of vision that includes everything that can be seen from a particular vantage point." Only when our horizons "fuse" with the horizons (historical traditions) of the text, does true understanding occur. Hans-Georg Gadamer, "The Historicity of Understanding” in The Hermeneutics Reader, 266-273.

${ }^{6}$ The projection of a possibility is the imaginary scaffold that understanding can be built upon: "Meaning, structured by fore-having, fore-sight, and fore-conception, is the upon which of the project in terms of which something becomes intelligible as something." Heidegger, Being and Time, 142. 
depicted as a three dimensional hermeneutical spiral indicating a progression through time. $^{7}$

This study suggests adapting the hermeneutical spiral model for biblical study by incorporating four sets of hermeneutical concepts, namely, the biblical text as the norm, three hermeneutical levels of micro-meso-macro, Christian principles of Scripture as the basis for faith and belief, 8 and five worlds of meaning. But first, the geometric depiction of what a spiral is, must be clarified. The term spiral in the English language can refer to two different geometric configurations: (a) a curve in a two-dimensional plane winding away from a central point with expanding radius (i.e. a spiral galaxy), and (b) a three-

\footnotetext{
${ }^{7}$ Strasser was the first to suggest the hermeneutical circle should be visualized as a spiral. Trying to synthesize three images of progress and synthesis (Heidegger's hermeneutical circle, Dilthey's "flight of steps", and de Boer's "ladder") Strasser described what he called "the spiral of understanding" as analogous to a "spiraling flight of stairs." Stephan Strasser, Understanding and Explanation: Basic Ideas Concerning the Humanity of the Human Sciences (Pittsburgh, PA: Duquesne University Press, 1985), 3233.

${ }^{8}$ From the Protestant Reformation, biblical principles of sola-tota-prima Scriptura will be referenced as they are incorporated into the hermeneutical model. See footnotes 12, 21, and 22 in this chapter.
} 
dimensional helix with a constant (cylindrical) or variable (conical) radius to its central axis.

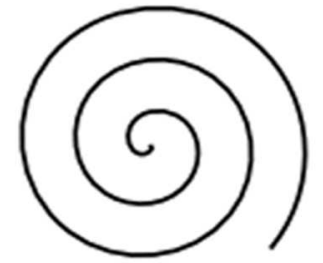

a.

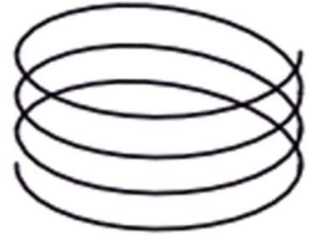

b.

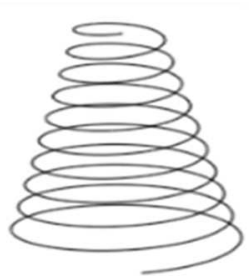

c.

Figure 3.1 Three geometric spirals. a. A two-dimensional spiral with an expanding radius. b. A three-dimensional spiral with a constant radius. c. A three-dimensional spiral with a variable radius.

For instance, Grant Osborne's hermeneutical spiral model ${ }^{9}$ is described as a threedimensional cone that reaches "from its [Scripture's] original meaning to its contextualization or significance for the church today" with ever-widening curves. ${ }^{10}$ This depicts a process of contextualization that moves away with increasing distance from its textual base of Scripture which implies lessening authority and fidelity in meaning. ${ }^{11}$ The

${ }^{9}$ Osborne, The Hermeneutical Spiral, 25-26.

${ }^{10}$ Osborne, The Hermeneutical Spiral, 22.

${ }^{11}$ In other words, as Osborne observes, it moves both vertically and horizontally "from the text to context [the context of the receiver]." He has three hermeneutical levels: Level one-what it meant (exegesis), Level two-what it means for me (devotional), Level three--how to share with you what it means to me (sermonic). Osborne recognized the problem of increasing distance from scriptural authority in the process. Thus, he urges preachers to "wed our application as closely as possible to our interpretation and to make certain that our interpretation coheres with the thrust of the text." Osborne's proposed solution is closer proximity of the spirals to each other. Osborne, The Hermeneutical Spiral, 22-23, 26, 417-419. 
alternative model proposed by this study incorporates the biblical text as the controlling long axis within the hermeneutical spiral, aligning all the loops in constant radius to it.

With the biblical text as the norming long axis of this model, biblical authority as expressed by the Principle of Sola Scriptura ${ }^{12}$ need not diminish over time or with progression through the loops. As this is the most important aspect of the hermeneutical spiral model for theology, the model will be referred to as the Axial Model from now on.

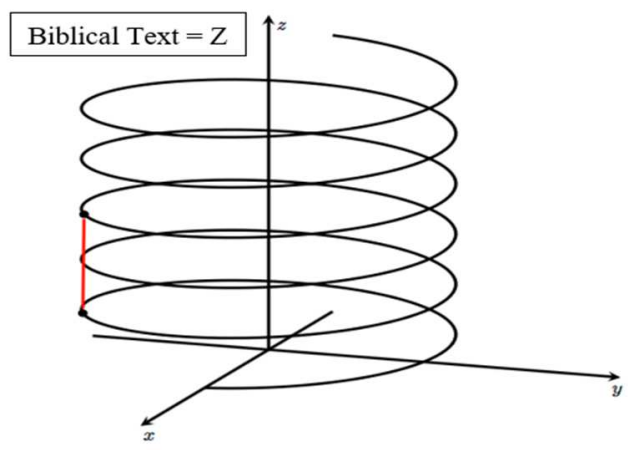

Figure 3.2 Biblical text as long axis $(Z)$ of Axial Model = Sola Scriptura.

Delineation of the hermeneutical loops is needed. For disciplined theological study and to help compare interpretive methods, the coils of the hermeneutical spiral

12 Principle of Sola Scriptura: “(1) Scripture is the uniquely infallible source of divine revelation that is available to contemporary humans collectively; (2) Scripture alone provides a sufficient and fully trustworthy basis of theology; and (3) Scripture is the uniquely authoritative and final norm of theological interpretation that norms all others." John C. Peckham, Canonical Theology: The Biblical Canon, Sola Scriptura, and Theological Method (Grand Rapids, MI: Eerdmans, 2016), 141. 
which represent subsequent steps in exposition require a simple yet comprehensive scheme to grasp the full meaning of the text. Fernando Canale's set of three hermeneutical levels is both comprehensive and elegantly simple for biblical scholars.

They are:

A. Micro-hermeneutics (biblical/textual principles of interpretation)

B. Meso-hermeneutics (theological/doctrinal principles of interpretation)

C. Macro-hermeneutics (the most inclusive ontological, epistemological, and articulation principles of interpretation).$^{13}$

Biblical fidelity requires all three levels to be normed by the biblical text, and not by imported secular paradigms. ${ }^{14}$ A cylindrical hermeneutical spiral which orders all the

${ }^{13}$ Fernando Canale, "Evolution, Theology, and Method," 21.

${ }^{14}$ Fernando Canale, "A Biblical Epistemology for Adventist Scholarship,” 15. 
methodological coils to the long axis of the biblical text within a constant radius, fulfills that need for all three levels of hermeneutics.

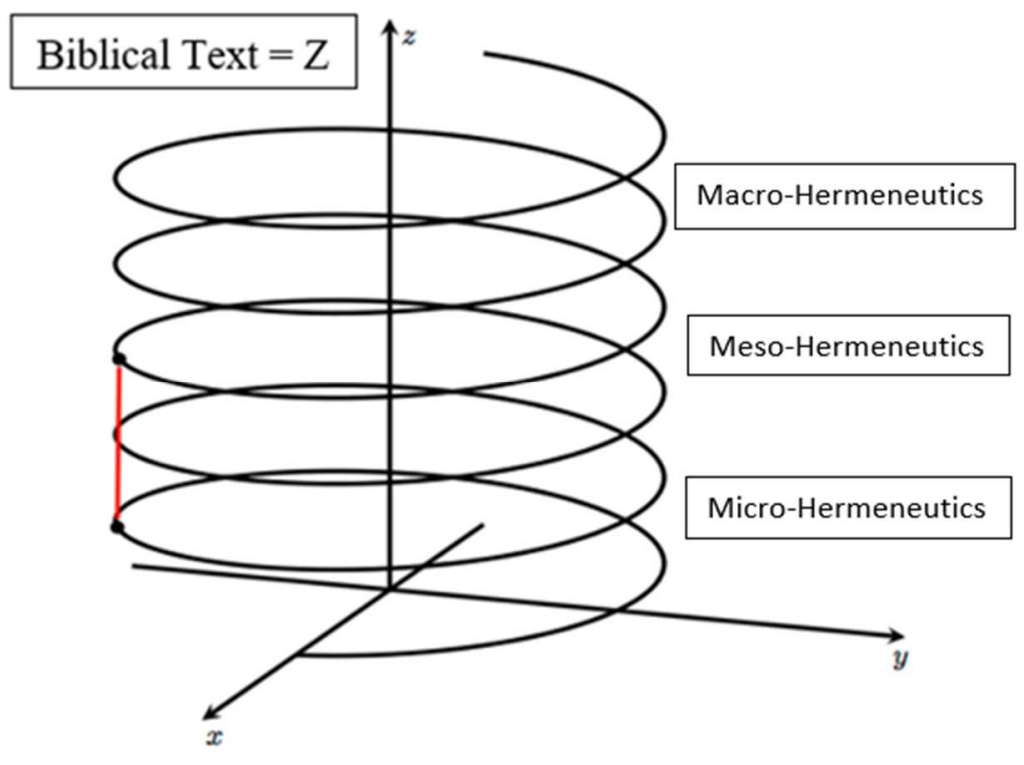

Figure 3.3 Three hermeneutical levels of the Axial Model: Micro-Hermeneutics-Sola Scriptura, Meso-Hermeneutics - Tota Scriptura, and Macro-Hermeneutics_-Prima Scriptura.

Where are the worlds of meaning in the Axial Model? The recognition that a text carries and channels worlds of meaning is incorporated into this model as filling the space between the spirals in the hermeneutical model. ${ }^{15}$ In literary analysis the phrase

15 "Every word causes the whole of the language to which it belongs to resonate and the whole world-view that underlies it to appear. Thus, every word, as the event of the moment, carries with it the unsaid, to which it is related by responding and summoning." Hans-Georg Gadamer, Truth and Method, 474. 
"behind the text" refers to the world that produced the text, including the social,

historical, linguistic, religious world of the author and the author's reason and purpose for the text. ${ }^{16}$ In a narrative, the world "in the text" refers to the configured world of the plot, which includes the characters, actions, space, time and relations between them. ${ }^{17}$ The world in "front of the text" indicates the viewpoint of the text, in other words, the "mode of being-in-the-world" that the text invites the reader to appropriate as their own. ${ }^{18}$ The world "above the text" in biblical studies refers to theocentric theology or metaphysical assumptions about ultimate reality. ${ }^{19}$ The world "below the text" refers to the fundamental nature of the cosmos, and in particular - the human self as the intended recipient of the text. $^{20}$

All five worlds of meaning emanate from the text (see Figure 3.4 below) and can be related to the principles of biblical interpretation. The $\mathrm{Z}$ axis which intersects the other

${ }^{16}$ Anthony Thiselton, Thiselton on Hermeneutics, 607-624.

${ }^{17}$ Aristotle's concept of emplotment in Poetics referred to a creative re-presentation of life-like temporal experiences in a coherent fashion. It usually had three main parts, a beginning, a middle and an end. Paul Ricouer, Time and Narrative, 34.

${ }^{18}$ Paul Ricoeur saw meaning as possibilities for a way of being that unfolds in front of the text as grasped by the reader; "the essential question is not to recover, behind the text, the lost intention, but to unfold, in front of the text, the 'world' which it opens up and discloses." Paul Ricoeur, Hermeneutics and the Human Sciences: Essays on Action, Language and Interpretation, ed. John B. Thompson (Cambridge, UK: Cambridge University Press, 1998), 111.

${ }^{19}$ God is understood by theists as the original source, ultimate Author, guarantor of meaning, and final illuminator of the Bible as revelation. Reading the biblical text is understood as being addressed by God and requires "obedient attention to God's address through his Word." Craig G. Bartholomew, Introducing Biblical Hermeneutics: A Comprehensive Framework for Hearing God in Scripture (Grand Rapids, MI: Baker Academic, 2015), 12. Non-theists' presuppositions about ultimate reality will also affect their study of the Bible (i.e., as literary reflections of a human community on history, symbolic metaphors for existential meaning, or religious illusions of reality).

${ }^{20}$ Anthropological presuppositions factor into every reading of historical narrative. From 
axes as their origin and source, is the anchoring text which norms the whole Axial Model using the Principle of Sola Scriptura through exegesis. The worlds of meaning behind and in front of the text are oriented along the $\mathrm{X}$ axis to the left and right side of the central origin chronologically and include the canon to represent the Principle of Tota Scriptura ${ }^{21}$ that provides the theological framework for the meso-hermeneutical level of theology. The worlds of meaning above and below the text are oriented vertically along the $\mathrm{Y}$ axis above and below the origin; they refer to biblical metaphysical foundations which are accepted through the Principle of Prima Scriptura ${ }^{22}$ for unfolding the macrohermeneutical level of philosophy. All five worlds of meaning (in the text, behind and in front of the text, above and below the text) are present and function on every level (micromeso-macro) of the Axial Model yet the target focus of each hermeneutical level ${ }^{23}$ will be on illuminating one of the three axes.

Augustine's rational mortal animal to Martin Heidegger's Dasein, from Max Scheler's loving being to Ernst Cassirer's symbolic animal, the understanding of self that a reader holds gets projected onto the human characters of the text as a lens. John Berry, "What Makes Us Human? Augustine on Interiority, Exteriority, and the Self," Scientia et Fides 5, no. 2 (2007), 95; Heidegger, Being and Time, 39-48 (42-52); Max Scheler, On the Eternal in Man, trans. Bernard Noble (New York, NY: Harper and Brothers, 1960), 74; Ernst Cassirer, An Essay on Man: An Introduction to a Philosophy of Human Culture (New Haven, CT: Yale University Press, 1944), 24.

21 The Principle of Tota Scriptura "holds that all of Scripture together functions as the infallible source of revelation, sufficient basis of theology, and authoritative and final norm of theological interpretation (2 Tim 3:16; cf. Matt 4:4).” Peckham, Canonical Theology, 141

22 The Principle of Prima Scriptura recognizes that "although Scripture is the uniquely infallible source of revelation that is collectively available, it is not the only source of revelation . . Scripture itself recognizes general revelation (Rom 1:18-23), extracanonical prophecy (Acts 2:17; 1 Cor 14:29), and the apostolic tradition of the first generation (2 Thess $3: 6) \ldots$ whereas the Trinity is the source of all legitimate revelation, the canon of Scripture is the uniquely infallible medium of revelation collectively available today is thus the prime revelation by which any other purported source of theological data must be judged." Peckham, Canonical Theology, 142-143.

${ }^{23}$ In other words, the micro-hermeneutical level of exegesis focuses on the biblical world of 
meaning in the text that emanates from the Z-axis (Sola Scriptura), the meso-hermeneutical level of theology focuses on the biblical world of meaning behind and in front of the text, the canon and world history, that comprises the X-axis (Tota Scriptura), and the macro-hermeneutical level of philosophy focuses on the biblical world of meaning above and below the text, metaphysical presuppositions about God and the cosmos, that constitutes the Y-axis (Prima Scriptura). 


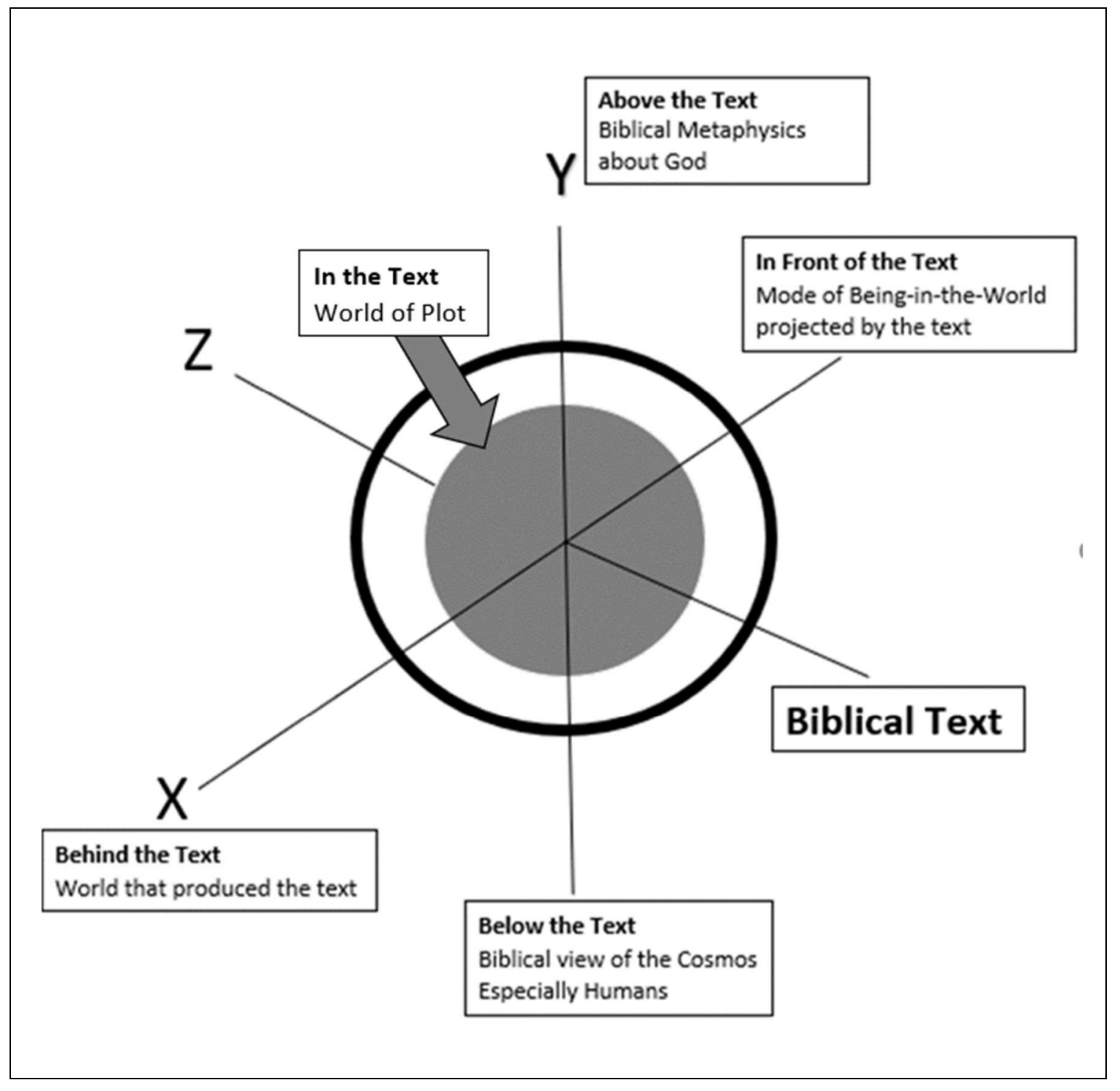

Figure 3.4 Axes of the Worlds of Meaning: Cross Section of Axial Model. 
There are no peripheral limits to the worlds of meaning, but there are individual limitations to accessing the fullness of these worlds. ${ }^{24}$ The sector of the worlds of meaning that are logistically accessible to an interpreter at a given time are represented by the coils of the hermeneutical spiral. Since the worlds of meaning permeate the spiral, the Axial Model is not an empty cylinder but more accurately, a filled-in helicoid..$^{25}$ In other words, the three-dimensional hermeneutical Axial Model is a spiral ramp.

To summarize, the worlds of meaning radiating from the biblical text are sliced through by the analytical loops of the spiral ramp. Every turn of the ramp goes through all the five worlds of meaning. Yet, the focus of a hermeneutical level is to explicate more fully one of the three axes X or Y or Z. For example, the micro-hermeneutical level discloses the world in the text—-focusing on the rotational area around the $\mathrm{Z}$ or long axis of the helicoid, drawing from the horizontal worlds behind and in front of the text (X axis) and the vertical worlds above and below the text (Y axis) as needed.

Given these modifications to the Axial Model, two questions arise: Is this hermeneutical model appropriate for Scripture and how does one enter it? ${ }^{26}$ Tentative

\footnotetext{
${ }^{24}$ Historical traditions add to the worlds of meaning along these axes. These worlds are not a closed system and will continue to accumulate through time, but individual interpreters may encounter logistical limitations due to their life background, resources, and skills.

${ }^{25}$ A helicoid is "a surface generated by a plane curve or a twisted curve which is rotated about a fixed line as axis and also is translated in the direction of the axis in such a way that the ratio of the two rates is constant." R. C. James, Mathematics Dictionary, $5^{\text {th }}$ ed. (1992), s.v. "helicoid."

${ }^{26}$ Heidegger once said about the hermeneutical circle, the precursor to the hermeneutical spiral, "What is decisive is not to get out of the circle, but to get in it in the right way." Heidegger, Being and Time, 143. Heidegger was concerned about anticipatory presuppositions which control the investigation so that the circle (not the circle of whole and parts, but the circle of understanding and interpretation) ends up confirming what was anticipated by the interpreter. His recommendation for avoiding this was to sort through one's anticipations, making them clear (especially if they arise from common notions outside the
} 
application is one way to test a model's appropriateness to the study object. Only when a model is tried on, can the fittingness of a new model to the substance be evaluated for whether it increases or decreases respectful understanding and transforms its target recipient. ${ }^{27}$

As for the second question about entering the spiral, since the Axial Model is a continuous spiral ramp that is continually readjusting the provisional understanding of the interpreter through time, what becomes critical is no longer where the spatial point of entry into this model is, but how one enters - the attitude of willing openness on the part of the interpreter, to continually listen and self-correct based on the textual evidence. ${ }^{28}$ As it is, systematic theologians may choose to enter the spiral at the macro-hermeneutical level, apologists will enter at the meso-hermeneutical level and exegetes will want to enter at the micro-hermeneutical level.

For this study, I have chosen to enter the hermeneutical spiral model at the microhermeneutical level and proceed to the macro-hermeneutical level inductively. ${ }^{29}$ This

object of study) in order to reject what is scientifically unsupportable by the object of study. See Jean Grondin's article, "What Is the Hermeneutical Circle?" in The Blackwell Companion to Hermeneutics, eds. Niall Keane and Chris Lawn (Malden, MA: Blackwell, 2016).

27 "We too determined that application is neither a subsequent nor merely an occasional part of the phenomenon of understanding, but codetermines it as a whole from the beginning." Gadamer, Truth and Method, 333; Jean Grondin, "Gadamer's Basic Understanding of Understanding," in The Cambridge Companion to Gadamer, ed. R. Dostal (Cambridge, UK: Cambridge University Press, 2002), 36-51. For legal or moral texts, the test of understanding is in the application or use of it. This is also true for working models.

${ }^{28}$ Ricoeur believed the best way into the circle of faith and understanding was by having a vital connection to the world of meaning of the writer: "one must understand to believe, but one must believe to understand." Ricoeur, as quoted by Grondin, "What is the Hermeneutical Circle?" 299-305.

${ }^{29}$ This is not to say that any interpreter can discount the contextual presuppositions of their existence, namely, his/her faith community, personal history, ethnic, political or cultural background in 
allows the hermeneutical journey to begin in conjunction with as many scholars as possible due to the universally accessible platform of Scripture. It also underlines the importance of looking at the text afresh as the normative long axis for the Axial Model.

Paul Ricoeur also recommended listening carefully to the text under study without suspicion as the first step of interpretation. ${ }^{30}$ Insightfully, he asked "whether there is, before the philosophical-theological interpretation, an interpretation that would not be an interpretation of the text or an interpretation about the text, but an interpretation in the text and through the text." ${ }^{\prime 31}$ Hence, the micro-hermeneutical level of analysis that elucidates the world of meaning in and through the text of the Aqedah, the area around the long $\mathrm{Z}$ axis, will be unpacked in this chapter through three steps. These three steps are

coming to the text. These accompany the interpreter regardless of where they enter the interpretive process. However, there are some advantages to starting with the text (micro-hermeneutical analysis) as discussed above, and my background as a physician predisposes me to respect the inductive method when confronted with an object of study.

${ }^{30}$ Paul Ricoeur's hermeneutical arc consists of (1) explanation — what it says or the internal world of the text, (2) interpretation and understanding - what it is about or the new understanding in the world of discourse, (3) appropriation - making it one's own or the new world of the interpreter. M. Taghinejad A. Ghasemi, A. Kubiri, M. Imani, "Ricoeur's Theory of Interpretation: A Method of Understanding Text," World Applied Sciences Journal 15, no. 11 (2011), 1624-1627.

${ }^{31}$ Paul Ricoeur, Figuring the Sacred: Religion, Narrative, and Imagination, ed. Mark Wallace, trans. David Pellauer (Minneapolis, MN: Fortress Press, 1995) 140. 
derived from the historical-grammatical-literary method: (1) morphological-syntactical, (2) narrative, and (3) literary-structural analysis.

\title{
Micro-Hermeneutical Analysis of the Aqedah
}

\author{
Morphological-Syntactical Analysis
}

Morphological-syntactical analysis is one of the necessary first steps in analyzing the details of the text through the grammatical-historical-literary method of exegesis. ${ }^{32} \mathrm{~A}$ focus on the words and sentence structure allows a study to "not yield in its first steps to allowing denominational confessions of faith, ecumenical creeds, or preferred systems of theological thought, such as Calvinism or Arminianism, to structure the work of this discipline. ${ }^{{ }^{33}}$ However, this level of minute analysis never remains exclusively within the text, because determining "the meaning of a word, the syntax of an utterance, the possibilities of stylistic variation, the dividing line between idiomaticity and metaphorical force" requires "an analysis of the underlying system." ${ }^{34}$ The underlying language system reflects the historical world of the author, the world of meaning behind the text. In

\footnotetext{
${ }^{32}$ Grammatical-historical exegesis was a term for the "honored method of the eighteenth- and nineteenth-century interpreters" that focused on the historically contextualized literal meaning of the text by unpacking the grammar and historical backgrounds of the author to recover the original meaning. "When Karl A. G. Keil used this term in 1788, his term grammatico approximated what we mean by the term literal, by which he meant the simple, plain, direct, ordinary, or natural sense of the passage. He was not referring simply to the 'grammar' that was used." Walter C. Kaiser, Jr. and Moisés Silva, Introduction to Biblical Hermeneutics (Grand Rapids, MI: Zondervan, 2007), 35. It is recognized that in order to determine the scope of meaning and the meaning of atypical syntax, the historical world "behind the text" must be considered. The third term, literary, refers to literary analysis which has become an important tool to perceive the writer's vision in constructing the text in a certain manner or genre.

${ }^{33}$ Kaiser and Silva, Introduction to Biblical Hermeneutics, 75.

${ }^{34}$ Meir Sternberg, The Poetics of Biblical Narrative (Bloomington, IN: Indiana University Press, 1985), 11.
} 
addition, the scope of meaning including typological and allusive inferences may also be affected by the final literary context, with the original text nested within a canon of latter texts originating from the chronological world of meaning in front of the text. At the same time, for a narrative text to make sense as a plot, the assumption that the characters are natural human beings in the same temporal-spatial earth as the reader and dealing with the same concept of God that the reader has access to, relies upon the implied worlds of meaning below and above the text. Thus, this hermeneutical spiral model recognizes that all the worlds of meaning are implicated on every hermeneutical level and has incorporated that understanding into its schematic representation. But for this chapter, the micro-hermeneutical level will be unpacked by focusing on the world of meaning in the text.

In order to study the text exegetically, each verse of the Aqedah in italics will be followed by a morphological-syntactical analysis of it. Robert Alter's English translation of the Aqedah will be used (for this chapter only) as the text for the verses due to its recognized literary and stylistic faithfulness to the dynamics of the Hebrew text. ${ }^{35}$ The goal of this chapter is not an exhaustive treatment of the Aqedah, but a horizontal engagement of the first level of the hermeneutical spiral model with the case text of the

\footnotetext{
${ }^{35}$ A respected literary scholar of the Bible, Alter's aim in translation was to present Genesis "in a language that conveys with some precision the semantic nuances and the lively orchestration of literary effects of the Hebrew and at the same time has stylistic and rhythmic integrity as literary English." Robert Alter, Genesis: Translation and Commentary (New York, NY: W. W. Norton, 1996), ix, 103-107.
} 
Aqedah so that the text, Genesis 22:1-19, can test and norm the Axial Model even as the model adds to our understanding of Abraham's test.

Genesis 22:1-19

1. And it happened after these things that God tested Abraham. And He said to him, "Abraham!" and he said, "Here I am."

The phrase and it happened after these things is a temporal marker "that often marks a new section in narrative" (found six times in Genesis: 15:1, 22:1, 22:20, 39:7, 40:1, 48:1) while placing it within the framework of preceding events. ${ }^{36}$ This is an

${ }^{36}$ GKC, 111g; Gordon Wenham, Genesis 16-50 (Waco, TX: Word, 1995), 98; Nahum Sarna, Genesis, 112. It is used seven more times in the Hebrew Bible (Josh 24:29; 1 Kgs 17:17; 21:1; 2 Chron $32: 1$; Ezra 7:1; Esth $2: 1,3: 1$ ). "Its function is always to insert a single event into a broader context. It presupposes a stage when the Abraham story was already known as a coherent unit, as in the case of the Joseph story." Claus Westermann, Genesis 12-36: A Commentary (Minneapolis, MN: Augsburg Fortress, 1985), 356. For an extended discussion on the meaning of the Hebrew root dabar as word, event or matter, see Barr, The Semantics of Biblical Language, 129-140. 
unmistakable indication from within the text for the reader to look at the literary world of meaning behind the text. ${ }^{37}$ This is how the text channels its own worlds of meaning.

Next, God (Elohim) $)^{38}$ as the subject precedes the verb "tested" and is also marked with a definite article (the God) ${ }^{39}$ so syntax and morphology point to God Himself with intentional emphasis as the divine source of the test. ${ }^{40}$ From within the text the God of Abraham is invoked and the reader's presuppositions from the world of meaning above

\footnotetext{
${ }^{37}$ Behind the text can refer to two levels (at least). The literary world of meaning refers to written texts staged as chronologically preceding this story while the literal world of meaning refers to the writer's existential background.
}

${ }^{38}$ Source critics ascribe Gen 22:1-13, 19 to E as the original story, due to style, composition and use of Elohim as the divine name. This leaves verses 14-18 as a later interpolation with YHWH as the preferred name for God. Omri Boehm points out that verses 11-12 also employs YHWH as God's name, mimics the style of the second angelic speech and is not necessary for logical plot development. If both are removed, Boehm sees the original story as revealing Abraham's disobedience to the divine command. On the other hand, G. W. Coates and J. van Seters believe the second angelic evaluation is indispensable to the story if the purpose of the test was to test Abraham's obedience. Omri Boehm, The Binding of Isaac, 23; George W. Coats, "Abraham's Sacrifice of Faith: A Form-Critical Study of Genesis 22," Union Seminary Review (Oct., 1, 1973), 395; J. Van Seters, Abraham in History and Tradition (New Haven,CT: Yale University Press, 1975), 239; see also R. W. L. Moberly, "The Earliest Commentary on the Akedah," 302323. Wenham adds two more arguments for including the last speech: sequential divine speeches are present in Gen 16, 17 and Gen 22 matches Gen 12:2-3 in literary style so correspondence in blessings at the end of both is fitting. "This is not to say that at one stage there may not have been a simpler, shorter account of the sacrifice of Isaac, but to identify the original account with vv 1-14 is too simple. . . . identifying the limits and content of earlier versions of the story is elusive." Wenham, Genesis 16-50, 103.

${ }^{39}$ Because the verb nissah is in the Perfect form, the subject comes before it. Jacques B. Doukhan, Hebrew for Theologians: A Textbook for the Study of Biblical Hebrew in Relation to Hebrew Thinking (Lanham, MD: University Press of America, 1993), 178. The definite article before Elohim "may also imply possession, 'his God." Victor Hamilton, The Book of Genesis, Chapters 18-50 (Grand Rapids, MI: Eerdmans, 1995), 100.

40 "The word [nissah] occurs only here in Gen. with God as subject; see Ex. 15:25; 16:4; Deut. 8:2, hr16; 13:4; 33:8; Judg. 2:22; 3:1, hr 4; Ps. 26:2; 2 Chron. 32:31. Apart from the late passages, Ps. 26:2; 2 Chron. 32:31, the object of God's testing in every case is Israel; they are concerned with the testing of Israel on the way through the desert and during the process of settling in Canaan." Though themes of obedience (Exod 16:4; Judg 2:22) and the fear of God (Exod 20:20) resemble Abraham's test, Westermann argues for a late dating for the Aqedah kind of test, because it is the testing of the individual. "The closest parallel in content to Gen. 22:1, the prolog to Job, is also a late text." Westermann, Genesis 12-36, 356. If the tables are turned and humans test God, "the testing is negative, uncalled for, and out of place." Hamilton, Genesis, 101. 
the text are about to be severely tested by what follows. Next, the direct object marker

points to the object of the test, Abraham himself. ${ }^{41}$ As the archetype of the covenant-

believer, what the test reveals about the ethics of human creatures in relationship with

God will test the presuppositions of the world of meaning below the text. What ties God

to Abraham in this narrative is the test event. But what does the immediate verse tell us

about this test? "Test" (nissah) ${ }^{42}$ is in the Perfect piel form which heightens its intensity.

\begin{abstract}
${ }^{41}$ In the Aqedah, no divine rationale for the test is initially given. The only modifying phrase directly connected to the divine test is "after these things." Abraham's obedient compliance, fearing God, and not withholding his son are divine accolades contingent on Abraham's test response. The temptation to be reductive (even in the face of the three commendations) and narrow the initial purpose of this divine test to only one or two attributes of Abraham uncovers the hidden presumption that the narrator's designation of Abraham as the object is inadequately nonspecific, so some interpreters go further by asking, "What is being tested in Abraham?" This path of reductive questioning then leads interpreters from the three Abrahamic religions (Judaism, Christianity and Islam) to highlight their own preferred virtue (obedience, faith, submission, respectively) against other options.
\end{abstract}

On the other hand, the Charity Principle of Interpretation recommends that an "interpretation that proposes the most value to the practice - which one shows it in the better light, all things considered" is the one to be preferred. If this principle is applied to the thematic framing of the Aqedah and the narrator's specific words regarding the test are accepted as rationally and intentionally complete — "God tested Abraham"- - means the whole being of Abraham, all that he is, knows, and is capable of, after years of interactions with God ("after these things") was being tested. For literary and aesthetic considerations to the logical criteria of the Principle of Charity see Ronald Dworkin, Law's Empire (Cambridge, CT: Harvard University Press, 1986), 52-53; W. V. O. Quine, Word and Object (Cambridge, CT: M. I. T. Press, 1960), 59. The logical Principle of Charity as applied to the narrator's wording "requires us to see others as much like ourselves in point of overall coherence and correctness - that we see them as more or less rational creatures mentally inhabiting a world much like our own." Donald Davidson, "Expressing Evaluations (1984)," in Problems of Rationality (Oxford, UK: Oxford University Press, 2004), 35-36.

42 Two meaningful concepts are tied to divine testing: God's divine judgment of the inner heart (Deut 8:2; cf. Ps 139:1, 23-24; Eccl 12:14) and the promise of atonement for the tested one (Exod 20:20 "Moses said to the people, 'Do not fear; for God has come to test [nissah] you, and that His fear may be before you, so that you may not sin"'). The Angel of Yahweh's reference to the Fear of God in Gen 22:12 ties Abraham's test to Israel's testing experience at Mt. Sinai (Exod 20:18). Doukhan writes, "The common words ("test," "fear of God") and the same threat of death shared by the two passages suggest that the same theology of "test" is implied. Instead of being an arbitrary and cruel act directed against the one tested, the divine testing brings the positive and promising perspective of divine judgement and atonement on behalf of the tested and is therefore to be understood in connection with the covenant of grace." God's covenant of grace culminated in the Jewish calendar on the Day of Atonement, where multiple linguistic connections are seen between the Aqedah and the description of the Day of Atonement in Leviticus 16. "More than any other biblical passage, this one shares the language with the test of the 'aqedah. We find the same association of the words 'olah 'burnt offering' (22:13; cf. Lev 16:3, 5), ra'ah 'appear,' in the same passive form (niphal) (22:14; cf. Lev 16:2), yiqqakh 'he took' (22:13; cf. Lev 16:5), and the 'one ram' (22:13; cf. 
Lev 16:6)." Doukhan, Genesis, 275, 285. Shalom Spiegel explains how the term nissah was considered as linking the Aqedah to the experience of Job, "The Talmudic Sages related nissah, 'put to the test,' of Gen.22:1 to ha nissah (if one try, venture, might one exchange) of Job 4:2; cf. B. Sanhedrin 89b: Satan got to the road ahead of him. He said to Abraham: 'If one venture a word unto thee, wilt thou be weary?' (Job, ibid.). Said Abraham to him: 'But as for me, I will walk in mine integrity' (Ps. 26:11).” Shalom Spiegel, The Last Trial, 145. 
Nissah can be translated to try, prove or attempt. ${ }^{43}$ God sets up the test of Abraham through dialogue: God called his name, "Abraham!"44 and Abraham responded, "Here I am. $" 45$

2. And He said, "Take, pray, your son, your only one, whom you love, Isaac, and go forth to the land of Moriah and offer him up as a burnt offering on one of the mountains which I shall say to you."

A particle of entreaty or exhortation, $n a$ (Alter translates it as "pray") 46 is inserted right after the imperative "take" and followed by four designations with increasing

${ }^{43}$ S. R. Driver Francis Brown, Charles A. Briggs, James Strong, Wilhelm Genesius, The BrownDriver-Briggs Hebrew and English Lexicon (Peabody, MA: Hendrickson Publishers, 1996), 650. Three verbs with origins in the refinement of metals by heat, including nissah, are bundled as parallels in Psalms 26:2 "Probe me, Yahweh and try me, test my heart and mind." From metallurgy, the core meaning of exposure for judgment and improvement arises. Thus, in testing, the relationship between man and God can be affected positively.

${ }^{44}$ Abraham was the divinely designated covenant name for Abram (Gen 17:5), given along with the ritual of circumcism (Gen 17:10) and promise of Isaac (Gen 17:16, 19, 21). Abram and Abraham both refer to fatherhood, Abram meaning exalted/great father and Abraham, perhaps father of nations. There is some debate among scholars on whether significant change of meaning occurred or whether the new name was a dialect variation without meaningful difference. See Alter, Genesis, 73; Doukhan, Genesis, 237; Von Rad, Genesis, 199; Sarna, Genesis, 124; Wenham, Genesis 16-50, 21. The one thing that is clear is that the name Abraham signals the covenant. Thus, covenantal fatherhood may be indicated by God's call as the theme for the test. If so, the test may hinge on the difference between a covenantal father and a noncovenantal father, perhaps testing the difference between Abram from Ur and Abraham of Canaan.

${ }^{45}$ Hinneni is literally "behold, me." The meaning of the word which usually embodies responsiveness and attentiveness has been translated as "Ready" (Speiser and Levenson), "Here I am" (Alter, Sarna, Westermann), "Here am I" (Von Rad), and simply "Yes" (Hamilton, Crenshaw). Sarna points out that "this is the only word Abraham utters to God in the entire episode." E. A. Speiser, "Genesis," in The Anchor Bible (Garden City, NY: Doubleday and Company, 1964), 162; Levenson, The Death and Resurrection, 126; Alter, Genesis, 103; Sarna, Genesis, 150; Westermann, Genesis 12-36, 352; von Rad, Genesis, 237; Hamilton, Genesis 16-50, 97; James Crenshaw, A Whirlpool of Torment, 19. It is the open response to God's momentous call: of Abraham (Gen 22:1, 11), Jacob (Gen 31:11, 46:2), and Moses (Exod 3:4). It is also a verbal response to family members: of Abraham (Gen 22:7), Isaac (Gen 27:18), Esau (Gen 27:1), Joseph (Gen 37:13).

${ }^{46} \mathrm{Na}$ ' is a "deferential particle of entreaty." Alter, The Art of Biblical Narrative, 44. Hamilton agrees that $n a$ ' can be translated as "please" or "I beg you." It may also have a strengthening function, as in admonition, exhortation or emphatic emphasis. Though it occurs more than sixty times in Genesis, it is only 
specificity_ “your son, your only son, whom you love, Isaac."47 They are to "go forth"

lek-lekha, ${ }^{48}$ or literally "go-for/to-you") to the land of Moriah ${ }^{49}$ and offer Isaac as a burnt

used five times in the Hebrew Bible when God is addressing a person (Gen 13:14, 15:5; 22:2; Exod 11:2; Isa 7:3). "Each time God asks the individual to do something staggering, something that defies rational explanations or understanding. Here, then, is an inkling at least that God is fully aware of the magnitude of his test for Abraham." Hamilton, Genesis 16-50, 101; Crenshaw, Whirlpool of Torment, 14. According to Sarna, adding the particle $n a$ ' to a command usually softens it to an entreaty. Sarna, Genesis, 151.

However, Abraham used this term na' in begging Sarah to present herself as a sister and not a wife, in order to save his life (Gen 12:13). Abraham's use of $n a$ ' in that situation may have softened his demand into a request but can hardly be taken lightly if she refused him, thereby putting his life at risk.

${ }^{47}$ Of the four appositional phrases, three are preceded by the direct object marker et-and one starts with the relative pronoun ("whom you love" in present tense). In appositions the et is repeated "when the noun in apposition is more precise or more determinate than the first noun." Joüon, A Grammar of Biblical Hebrew, $\S 112 \mathrm{aA}, \S 132 \mathrm{~g}$. Levenson has argued that yahid translated here as "only" can also mean "unique" or "favored one." Levenson, Death and Resurrection, 127. The verb "love" encountered in the Bible for the first time in this verse, is in the Perfect form. "Note that the meaning of the Perfect here is not so much to express a past event or a finished action, but rather to indicate the perfection of his love; the idea is that Abraham loved, has always loved, still loves and perfectly loves his son Isaac." Doukhan, Hebrew for Theologians, 81. The next use of this term for love (Gen 24:67) will be in Isaac and Rebekah's husband-wife relationship. Sarna, Genesis, 151.

${ }^{48}$ Lek-lekha: When the preposition connects to a pronominal suffix that refers to the same person as the subject of the verb, it means "for whom, to whose advantage (or disadvantage) something is done. This indirect reflexive nuance can be translated as a reflective verbal nuance. Joüon, A Grammar of Biblical Hebrew, $\S 133 \mathrm{~d}$; Doukhan brings up three nuances of meaning for this unique term: emphasis, reflexive, and dative of interest. The dative of interest may also imply "the exclusion of anyone else from sharing this test." Doukhan, Hebrew for Theologians, 81-82. These nuances can be conveyed by "go-(yes), you!" "get-yourself-and-go," and "go-for-your-own-sake," respectively. Outside of Genesis, it is found in SOS 2:10, 13 .

${ }^{49}$ Moriah could be related to the verbs "to see" or "to fear." Jewish tradition identifies the "mount of the Lord" in Gen 22:14 with the site of the Temple at Jerusalem on "mount Moriah" (II Chron 3:1); Samaritans believe the site was Mt. Gerizim near Shechem; Muslims believe it was Mt. Marwah, close to Kaaba in Mecca. The Vulgate translates the land of Moriah as the "land of the vision"; the Septuagint translates it as "the high land." Wenham, Genesis 16-50, 98. 
offering on one of the mountains there. ${ }^{50}$ God then promises to verbally communicate later to designate the mountain chosen. ${ }^{51}$

3. And Abraham rose early in the morning and saddled his donkey and took his two lads with him, and Isaac, his son, and he split wood for the offering, and rose and went to the place that God had said to him.

Because Abraham gets up early in the morning to carry out the command, the implication is that the command was given the previous night. ${ }^{52}$ Single-handedly, Abraham enacts all six verbs of this verse ${ }^{53}$ surrounded by his human companions: two

50 "Offer him up, there, for offering" is one literal translation. Doukhan, Hebrew for Theologians, 84. The dominant understanding is that Abraham is to cause Isaac to "go up, be offered up" -(ל) "for" (to become, as) a burnt offering. This is what Abraham does in the story. But another meaning of ל? is "for" (in reference to, in regard to) offering, i.e. for him to perform or do the burnt offering. If this minority option is taken, the translation would read "Make him go up, there, in regard to a burnt offering." See BDB ? 5ibGen 22:2 (in reference to verbs of motion). In conclusion, the meaning of context and requires careful judgment. Curiously, Genesis Rabbah has a remark on Genesis 22:2 that refers to the root of olah ("that which goes up to heaven" -whole burnt offering) as alah (to go up): "When I said to you, 'Take,' I was not altering the utterance of My lips. I did not say to you, 'Slaughter him,' but, 'Bring him up.' You have brought him up; [now] take him down." Jacob Neusner, Genesis Rabbah (Lanham, MD: University Press of America, 2001), 56:8.

${ }^{51}$ The test is not fully contained in the initial command but remains open-ended and ongoing with a promise of further direction and verbal engagement. Whereas the initial call to Abraham in Gen 12:1 referred to a large territory - "to a land I will show you," the test of Gen 22:2 is very specific-"one of the mountains [in the land of Moriah] that I shall say to you." The first call referred to visual confirmation, the test refers to auditory confirmation. And yet, in the Aqedah, there is no divine verbal confirmation of the exact site, but visual confirmation is specifically mentioned (v. 4).

52 The phrase getting up early in the morning and saddling his donkey may also portend anxiety and danger. After prolonged negotiations with the Lord, Abraham got up early only to see the smoke billowing up from the destruction of Sodom and Gomorrah (Gen 19:27); getting up early and saddling his donkey are enacted by Balaam (Num 22:21) as he set out to curse Israel; saddling his donkey is connected to Ahithophel's intent to commit suicide at home (2 Sam 17:23) and to Shimei's sure death when crossing his imposed boundary (1 Kgs 2:40).

${ }^{53}$ The gender and number of the subject of all the verbs is masculine singular with Abraham as the agent. All the verbs are in qaal form except one. The splitting of the wood is in the intensive piel form; Abraham, by himself, was chopping vehemently. 
lads and Isaac, his son. ${ }^{54}$ The endings of vv. 2 and 3 match: v. 3 "which God had said to him" fulfills the promise of v. 2 "which I shall say to you." 55

4. On the third day Abraham raised his eyes and saw the place from afar.

Bereft of a transitioning conjunction and separated from the ensuing action, the phrase "on the third day" jumps out. Temporally, it can refer to the third day of the journey which was about 75 kilometers $(45 \text { miles })^{56}$ from Beersheba but it may also indicate a pending momentous event. ${ }^{57}$ It is followed by a recognized metaphor for

${ }^{54}$ A string of phrases tied together by waw ("and") is common in Hebrew. What stands out is when "a chain of coordinated terms may be split by an intruding element" such as "he took two of his servants with him and Isaac, his son." Joüon, Grammar, §177t. The terms "son" or "father" appears 12 times in this narrative of 19 verses, signifying this relationship as critically meaningful for the test.

${ }^{55}$ The promise was given in imperfect tense, the reference to it is in perfect tense. Was there a communication of God to Abraham between these verses? If so, we are not told about it.

${ }^{56}$ J. Davidson, “Abraham, Akedah and Atonement,” 236.

57 Syntactically, it is rare to have a new paragraph begin without a conjunction. Francis I. Andersen, The Sentence in Biblical Hebrew (Hague, NL: Mouton Publishers, 1974), 37. It is also odd to have a waw conjunction right after 'on the third day' unless there is an introductory phrase before it such as 'and it happened.' Joüon, Grammar, $\S 176 \mathrm{hN}$. These suggest the phrase "on the third day" is to be taken as more than a temporal introduction. It may exhibit the qualities of a metaphor rooted literally in the third day as the chronological setting for the rest of the pericope, indicating the significant spatial/distance from all that precedes and follows, and figuratively presaging a consequential event (references to three-day units are plentiful: Gen 30:36; 31:22; 34:25; 40:20; 42:18; Exod 3:18; 5:3, 8:27, Num 10:33; Jonah 3:3). Westermann, Genesis 12-36, 358-359; Sarna, Genesis, 361. 
insightful recognition, literally "he lifted up his eyes and he saw the place from afar

off." ${ }^{58}$

5. And Abraham said to his lads, "Sit you here with the donkey and let me and the lad walk ahead and let us worship and return to you."

Abraham commands his servants to remain behind with the donkey for their own sakes. ${ }^{59}$ Separating himself with his son from the servants with the donkey, Abraham shares his resolve to go, worship ${ }^{60}$ and return together with his son. ${ }^{61}$

6. And Abraham took the wood for the offering and put it on Isaac his son and he took in his hand the fire and the cleaver, and the two of them went together.

A second preparation is described with Abraham, again the sole actor for the first three verbs (took, put, took) ${ }^{62}$, places the designated wood $^{63}$ on the designated victim,

\footnotetext{
${ }^{58}$ Joüon, Grammar, §125ia. See Gen 13:10, 18:2, 22:13, 24:63, 33:1, 33:5, 43:29, Num 4:2, Josh 5:13. Literal translation from Doukhan, Hebrew for Theologians, 92-93. Joann Davidson mentions that this phrase occurs over 860 times in the Hebrew Bible; "over 240 times in the Pentateuch; and almost 100 times in Genesis alone. Forms of 'to see' also occur seven times within the 15 verses of Genesis 22 . Thus, it becomes tantalizing to notice the few times when the rare phrase 'lifting up the eyes' is tagged to the already obvious word for 'seeing.' Could this possibly imply more than mere physical sight?" J. Davidson points to passages above as biblical events where vertical spatial direction is not the main point of this phrase, but emotional or intelligent comprehension is suggested. Davidson, "Abraham, Akedah, and Atonement," 62. See also Gudmundur Olafsson, "The Use of NS in the Pentateuch and its Significance for the Biblical Understanding of Forgiveness," (PhD diss., Andrews University, 1988), 148-154 and C. S. Reif, “A Root to Look Up: A Study of the Hebrew nasa' 'ayin," Vetus Testamentum Supplements 36 (1985): 230-244.

${ }^{59}$ The reflexive nuance of $ל$ dativus commode is recognized here, especially because it follows a verb in the imperative. "(You) Sit for yourselves with the donkey." P. Joüon, Grammar, 133d. Doukhan adds that it may, instead, carry the emphatic nuance "Abraham does not want to be followed." Doukhan, Hebrew for Theologians, 94.

${ }^{60}$ The core meaning of worship is to "bow down" or "prostrate." A more recent explanation is based on the root חוה, meaning "to prostrate, to wind (like a serpent)." Doukhan, Hebrew for Theologians, 96.

${ }^{61}$ The three verbs (walk, worship, return) are in the cohortative form, indicating the volitive sense of desire or determination, not a flat announcement of an action that will be undertaken. Wilhelm Genesius,
} 
Isaac. Then with his hand, he grabs the brazier ${ }^{64}$ and a large butchering knife. ${ }^{65}$ Literally, "and they went, the two of them, together." ${ }^{6}$

7. And Isaac said to Abraham his father, "Father!" and he said, "Here I am, my son." And he said, "Here is the fire and the wood but where is the sheep for the offering?" Isaac attempts to ask a question, but wayy'omer (and he said) is awkwardly repeated twice suggesting hesitation, before his voice finally breaks out. A more literal translation would be, "And he said, Isaac to Abraham his father-and he said, 'My Father!" ${ }^{67}$ Abraham responds to Isaac in the same way he responded to God, hinenni ("Here I am,") adding the possessive vocative beni ("my son"). Alter captures the verbal

Genesius' Hebrew Grammar and Davidson's Hebrew Syntax (Piscataway, NJ: Gorgias Press, 2007), §108. Alter correctly translates the nuance as "Let us" but since Abraham is not asking really asking permission of his servants to carry out his plans, it could also be translated as "We are determined" or "We want to."

${ }^{62}$ These verbs are all in the masculine singular form.

${ }^{63}$ Hidden in the Hebrew morphology is increasing specificity on the event that will require the wood: in verse three it was wood for an offering, in verse six it is wood for the offering. Joüon, Grammar, $\S 139 \mathrm{a}$.

${ }^{64}$ Fire is a literal translation, but since that is unlikely, others suggest it may be referring to tinder, firestone, fire-flint, or a brazier with hot coals in it. BDB, 77; Speiser, Genesis, 163; Hamilton, Genesis 1650, 98; Sarna, Genesis 152, respectively.

${ }^{65}$ This kind of knife is identical to the one used to cut up the Levite's concubine in Judges 19:29 and is mentioned in parallel with swords in Proverbs 30:14. "E. A. Speiser notes, quite rightly, that the Hebrew term here is not the usual biblical term for knife, and makes a good argument that it is a cleaver. Other terms from butchering, rather than sacrifice, are used: to slaughter (verse 10) and to bind (verse 9-a verb occurring only here but used in rabbinic Hebrew for binding the legs of animals)." Alter, Genesis, 105.

${ }^{66}$ This phrase is repeated (v. 6, 8) then modified at the end of the test- - and they rose and went together" (v. 19).

${ }^{67}$ Jacques Doukhan analyzes this verse in detail, noting both the grammar and implied silences to masterfully capture the grammatical chiastic center of the narrative. See Doukhan, "The Center of the Aqedah," 17-28. 
resemblance between Abraham's response and Isaac's question by having “Here I am, my son" followed by "Here is the fire." ${ }^{68}$ Isaac sees the fire and the wood but wonders about the lamb ${ }^{69}$ for the offering. ${ }^{70}$

8. And Abraham said, "God will see to the sheep for the offering, my son." And the two of them went together.

Elohim as the subject precedes the imperfect verb in Abraham's response, emphasizing God as the source of the solution. ${ }^{71}$ The verb yir'eh is an idiom and can mean visualizing or providing, both meanings are coupled in Abraham's later naming of the site, YHWH-yir'eh in v.14. Due to the Hebrew lo "to/for/in regard to" that follows the verb yir'eh “to see," Abraham's answer may be heard different ways: intensive "God, Himself, will see to the sheep", emphatic "God will certainly see to the sheep", or reflexive "God will see for Himself, the sheep." 72 There is no direct object marker before the sheep so 'the word 'lamb' can be heard as in apposition to the phrase 'He will see

${ }^{68}$ In Hebrew, Abraham's hinneni (literally, "Behold, me”) is echoed in Isaac's question that starts with hinneh ("Behold"). The meaning is translated as here in English.

${ }^{69}$ The Hebrew term here is seh meaning, a "four-legged animal" or "small livestock- a general term for a sheep or goat." $B D B$, s.v. "שש". Some translations use the term "sheep." Most English translations use "lamb" here since it alludes to Isaac and the scope of meaning for seh does include the oneyear old Passover lamb or goat (Exodus 12:3-5) which was a substitute for the firstborn son. In Ezekiel 34:17 seh refers to both rams and male goats.

${ }^{70}$ It is clear from this verse that animal sacrifices were already a customary ritual for this family.

${ }^{71}$ The usual word order for imperfect verbs is that the subject follows the verb. In this verse, the subject precedes the imperfect verb, emphasizing "God" as the focus of Abraham's answer. Hamilton, Genesis 16-50, 109. Syntactically, God was emphasized as the source for this test (v. 1) and God is emphasized as the source for the solution (v. 8).

${ }^{72}$ Hamilton, Genesis 16-50, 109; Doukhan, Hebrew for Theologians, 102. 
Himself,' meaning He will see Himself, (as) the lamb."73 Then, this one and only recorded dialog between Abraham and Isaac in the Bible ends with the touching "my son." ${ }^{74}$ Once again, the two resume walking together.

9. And they came to the place that God had said to him, and Abraham built there an altar and laid out the wood and bound Isaac his son and place him on the altar on top of the wood.

After the two arrive ${ }^{75}$ at the divinely designated location, ${ }^{76}$ Abraham carries out the last preparations alone ${ }^{77}$ and binds his $\operatorname{son}^{78}$ before placing him on top of the wood ${ }^{79}$

\footnotetext{
${ }^{73}$ Doukhan, Genesis, 280. Doukhan also suggests one reflexive possibility: "God will see the lamb, [namely] Himself, my son.”

74 "My son" can be understood either as a vocative (Abraham addressing his remarks to his son, as above) or as an appositive, rendering this sentence meaning as "God will provide... for a burnt offering, i.e., you, my son." Hamilton, Genesis 16-50, 110; Crenshaw, Whirlpool of Torment, 23; Sternberg, The Poetics of Biblical Narrative, 192. Midrash Gen. Rabbah 56:4 comments on this verse: "AAt all events, God will provide himself the lamb, O my son ; and if not, Thou art for a burnt-offering, my son.' So they went both of them together - one to slaughter and the other to be slaughtered."
}

${ }^{75}$ The arrival_-"and they came"-fulfills the test command to go in v. 2.

${ }^{76}$ Consistently throughout this narrative the sacredness of the site hangs solely on the word of God: "the place that God had said to him." No physical or inherent qualities justify that place as holy.

${ }^{77}$ The verbs built, laid, bound, placed are all in the masculine singular. Abraham remains the main actor throughout this test.

${ }^{78}$ This verse is the basis for the Jewish name of the narrative "Aqedah" (Binding [of Isaac]). Isaac is bound before he is laid on top of the wood by Abraham. According to Leviticus, for a burnt offering, the animal is usually killed first, cut into pieces, then the pieces are laid upon the already burning wood. See Lev 1:10-13. Abraham's procedural order does not match the sanctuary sacrifice ritual for animal burnt offerings, perhaps because this is a human victim and not an animal.

${ }^{79}$ Of the non-living implements needed for the sacrifice, wood is the most mentioned item (wood$5 \mathrm{x}$, altar-2x, fire-2x, knife-2x) and the one most manipulated (chopped, took, placed on Isaac, Isaac notes it, laid out on altar, Isaac is placed over it). At the sacrificial site, Abraham carefully lays out (ya 'arok-to lay out, set in rows, to get ready, set out in order) the wood on the altar. 
on the newly built altar. ${ }^{80}$ This verb 'aqad (to bind, to tie up) appears only here in the Bible. $^{81}$

10. And Abraham reached out his hand and took the cleaver to slaughter his son.

Previously, Abraham simply "took in his hand the fire and the knife" (v. 6) but here, the meticulous and drawn-out depiction of "stretching out or sending out" his hand" precedes the taking of the butchering knife. Then Abraham's unspoken intention- “to slaughter his son"- is revealed. ${ }^{83}$

\section{And the Lord's messenger called out to him from the heavens and said, "Abraham,} Abraham!" and he said, "Here I am."

Messenger is the correct meaning for mal'ak. ${ }^{84}$ Like the messenger of Elohim that rescued Ishmael in the previous chapter (Gen 21:17), Isaac is rescued by the messenger

${ }^{80}$ Altars could be built from earth or unwrought stone. Exod 20:24-25.

81 'Aqad appears as an adjective in the story of Jacob to describe "striped, streaked" animals of the flock. Genesis 30:35, 39, 40;31:18. This verse (Gen 22:9) is the only time it is used as a verb in the Scriptures. It refers to the binding of Isaac. One may wonder, if Isaac is a willing victim, why would he need to be bound? It may have been a customary step for burnt offerings. Levinson, Inheriting Abraham, 79. The sages surmised it could have been Isaac's wish: "Targum Jonathan and Targum Jerushalmi ad Gen. 22:9: 'Bind me properly lest I start suddenly, and there (will) occur a blemish in your offering." Spiegel, The Last Trial, 21, note 14.

${ }^{82}$ It is to be noted that the angelic prohibition of v. 12 retracts this exact movement of Abraham's hand reaching out, the actual grasping of the knife by the same hand is not mentioned. Stretching out of the hand is a common description pending action, both positive and negative (Gen 8:9, 19:10, 38:28, 48:14, Exod 4:4, 7:5, 19, 8:6), but because of the context here, the action is laden with trepidation.

${ }^{83}$ Even while Abraham's actions march toward completion, Abraham's mental state has been ambiguous until this exact moment. The word sehot "slaughter" is the term for cutting up animals for sacrifice or food.

${ }^{84}$ Mal'ak can mean a "messenger (Gen 32:4), a prophet (Isa 42:19), a priest (Mal 2:7)," or "a heavenly being (I Chr 21:15)." Doukhan, Hebrew for Theologians, 108. In this case, "the meaning of the genitive group is indeterminate even though the nomen rectum is a proper noun." Joüon, Grammar, 
of YHWH ${ }^{85}$ who calls ${ }^{86}$ Abraham's name twice from heaven. Abraham readily responds in the same manner as at the beginning of the test, "Here I am."

12. And he said, "Do not reach out your hand against the lad, and do nothing to him, for now I know that you fear God and you have not held back your son, your only one, from Me."

The initial action singled out for retraction is the stretching out of Abraham's hand against the lad, but then the prohibition is broadened to any action in order to ensure total safety for Isaac. ${ }^{88}$ The reason for countermanding the test is: for now I know ${ }^{89}$

139c11. The phrase here is usually translated an "angel of Yahweh."

${ }^{85}$ YHWH has the root hawah meaning "to be" or "to speak." Existence and word are related concepts in Hebrew. "The form, יהוה, is probably to be analyzed as a hiphil, Imperfect, third person, meaning 'he will cause to be.' The approximate original pronunciation is Yahweh." Doukhan, Hebrew for Theologians, 108.

86 The messenger of YHWH loudly calls from a distance to Abraham, repeating his namesuggesting urgency. Westermann, Genesis 12-36, 361. To restrain a father about to slaughter his son, the messenger calls out, ironically, “Abraham! Abraham!” [Great Father of Nations! Great Father of Nations!]. Abraham, in loyal opposition, had reminded God of His role as the Judge of all the Earth. Was God returning the favor here by reminding Abraham that he was to be an exemplary Father of a covenanted nation?

${ }^{87}$ This is the third and last time Abraham responds with hinneni. "First to God, then to Isaac, now to the divine messenger" (who identifies with God in the next verse). Alter, Genesis, 106.

88 The jussive תעש "you do anything" with the negation " Doukhan, Hebrew for Theologians, 110; Joüon, Grammar, §147b.

${ }^{89}$ Temporality is connected to divine knowledge in this verse. Whether this is an anthropomorphism, or a characteristic of divine epistemology will be discussed more fully in chapter 4 that follows. Doukhan offers two notes on its meaning here: "1) The meaning of the Perfect implying complete knowledge [and] 2) The word ידע "to know" implies intellectual, as well as physical knowledge. This word is used to express the intimacy and the experience of the conjugal relationship (Gen 4:1)." Doukhan, Hebrew for Theologians, 111. This verb root in the perfect form was used by God in Gen 18:19 "For I know him, that he will command his children and his household after him and they shall keep the way of the Lord" and more recently in regard to Abimelech in Gen 20:5, "I know that you have done this in the integrity of your heart." Abraham used it in regard to Sarah's beauty in Gen 12:11. 
you are God-fearing ${ }^{90}$ for ${ }^{91}$ you have not withheld ${ }^{92}$ your son, your unique son ${ }^{93}$ from

Me. ${ }^{94}$

13. And Abraham raised his eyes and saw and look, a ram was caught in the thicket by its

horns, and Abraham went and took the ram and offered him up as a burnt offering

instead of his son.

Once again in this narrative the visual idiom for insight is used, "Abraham raised

his eyes and saw," ${ }^{95}$ but it is intensified here with the interjection of surprise, "and

behold," the solution is seen! Whether the ram is located behind Abraham, seen

afterwards, or is identified as one animal depends on whether the next term is read as

(אחר) "behind, afterwards" or (אחד) "one, a," differing by a stroke on the last letter. ${ }^{96}$ In

${ }^{90}$ Yare "fearing" is a participle in the absolute state in construct with the accusative-God, it is functioning as a verbal adjective here. Joüon, Grammar, §1211. Within the two verses of 11 and 12 the divine names (Yahweh and Elohim) are intermingled synonymously by several references to divine identity. The Messenger of $Y H W H$ calls Abraham a fearing [one] of Elohim, then refers to itself as divine "You did not withhold your son...from $M e . "$

$\S 170 \mathrm{c}$.

${ }^{91}$ The context indicates this waw should be translated as a causal relation, "for.” Joüon, Grammar,

92 "to withhold, to keep back" was used by God just two chapters previous to this in His explanation of how He withheld Abimelech (Gen 20:6).

${ }^{93}$ Only the first two appellations in the test command for Isaac in v. 2 are repeated here. The last two, "whom you love, Isaac," are dropped in both v. 12 and in v.16.

${ }^{94}$ In Gen 16:7-14, the angel of YHWH saves Hagar who refers to him as "the Lord that spake unto her." In Gen 31:11-13 the angel of Elohim tells Jacob, "I am the God of Bethel." In Exod 3:2-6 the angel of YHWH appears to Moses in the burning bush and says, "I am the God of thy Father."

95 Just as in v. 4, J. Davidson notes it is rare to tag the phrase "lifting up the eyes" to the "already obvious word for 'seeing."” Davidson, "Abraham, Akedah, and Atonement," 62-64.

${ }^{96}$ Ancient manuscripts support both variant readings (Septuagint, Syriac, Vulgate, and the Targum support 'ekhad; most of the Masoretic texts support 'akhar). Hamilton translates 'akhar as "another" and Wenham translates it with the sense of "immediately after" as in "just caught." Victor Hamilton, Genesis 
age, the ram is mature- - horns signaling at least three years old, and Abraham fulfills all three verbs of the initial command (go, take, offer) on the ram (went, took, offered as a burnt offering) instead of his son..$^{97}$

14. And Abraham called the name of that place YHWH-yireh, as is said to this day, "On the mount of the Lord there is sight."

The name of that "very place"98 focuses attention, not on the test subject Abraham, but on God. 99 "God-will-See/Provide” captures Abraham’s previous reply to Isaac's question, “God will provide." The next phrase in the text points to the present time of the narrator, somewhere in the world of meaning in front of the event, but within the writing of the text, ${ }^{100}$ where the verb now carries a passive niphal sense, "On the mountain of YHWH, He/he/it will be seen." Who or what the subject of the verb is whether God will appear and be seen by the believer, whether the believer will be seen by

16-50, 133; Wenham, Genesis 16-50, 99 (note 13a). Sarna supports his translation of "a ram," by pointing to Gen 10:4 as another example where the 7 dalet was substituted for a 7 resh. Sarna, Genesis, $153,71$. Daniel 8:3 matches with "And I lifted up my eyes and saw, behold, one ram." This suggests that "one ram" may be the appropriate phrasing for both, especially since they both share themes of the Day of Atonement (Yom Kippur). For an excellent discussion of the grammatical/syntactical/textual reasons for preferring 'ekhad over 'akhar see Doukhan, Genesis, 285.

97 "The drama of this substitution is also emphasized through the phrase 'behold, a ram' answering Isaac's earlier question: 'behold . . . where is the lamb?' v. 7." Davidson, “Abraham, Akedah, and Atonement," 64.

98 The Hebrew puts extra emphasis on the "very place." Literally: “And Abraham called the place, the it-YHWH-yireh." Doukhan, Hebrew for Theologians, 116.

${ }^{99}$ Hamilton wryly remarks, "He does not call this site 'Abraham-shama' ('Abraham obeyed'). . . . The name highlights only the beneficent actions of Yahweh.” Hamilton, Genesis 16-50, 113.

100 The world of meaning in front of the text refers to the literal world of meaning after the Aqedah event, as captured by the literary world of meaning in the text. 
God, whether the divine provision is what is seen (ram), all three subjects are allowed by the grammar. ${ }^{101}$ Alter preserves the original ambiguity with his translation: "there is sight."

15. And the Lord's messenger called out to Abraham once again from the heavens,

The messenger of YHWH calls a "second time" from the heavens. ${ }^{102}$ The

messenger prefers to remain out of sight, limiting his presence to words. ${ }^{103}$

16. And He said, "By my own Self I swear, declares the Lord, that because you have done

this thing and have not held back your son, your only one,

Of all the oaths in Genesis, only here does YHWH swear by himself. ${ }^{104}$ The causal

clause that follows the strongly nuanced ("because") has two parts, with the emphasis

101 The root of the verb see, ראה in the niphal "is regularly used of the Lord appearing to men (cf. $12: 7 ; 17: 1 ; 18: 1)$, thus making a link backward with Abraham's past experience and forward to Israel's future experiences on the mountain of God (Exod 3:1-2, 16; Lev 9:4, 6, etc.)." Wenham, Genesis 16-50, 111.

102 The next four verses were commonly believed to be a later addition by historical-critical scholars. But the very word that caused the most doubt is now seen as a significant 'glue'. Senit "second," far from signaling an awkward insertion, may be the literary marker for the pattern of repetition called "build-up and climax" (BUC) a pattern seen in other Ugaritic texts and found in ancient Hebrew narratives (cf. I Kgs 19:7).

The identifying characteristics of BUC are "(a) the repeated events require two steps to reach the given event's conclusion. Since the first step, build-up, fulfills only one part of the event's expected goal, it anticipates a second step, which is decisive in leading to the narrative climax. (b) The presence of the adverb שנת, 'a second time' (or אוד 'again') in the second episode's introductory statement implies that a previous parallel event had taken place and demonstrates that the repeated events form a unit. (c) The characters in each repetition of the BUC are identical both characteristically and in number." Esther H. Roshwalb, "Build-up and Climax in Jeremiah's Visions and Laments," in Boundaries of the Ancient Near Eastern World: A Tribute to Cyrus H. Gordon, eds. Meir Lubetski, Claire Gottlieb, Sharon Keller, Journal for the Study of the Old Testament Supplemental Series 273 (Sheffield, UK: Sheffield Academic Press, 1998), 111 fn; Gary A. Rendsburg, "Variation in Biblical Hebrew Prose and Poetry," in Built by Wisdom, Established by Understanding: Essays on Biblical and Near Eastern Literature in Honor of Adele Berlin, ed. Maxine L. Grossman (Bethesda, MD: University Press of Maryland, 2013), 214-215; C. H. Gordon, "Build-up and Climax," in Studies in Bible and Ancient Near East Presented to Samuel E. Lowenstamm, eds. J. Blau, Y. Avishur (Jerusalem, IL: E. Rubinstein's, 1978), 29-34. 
on the first - "you have done this thing" over the second "and not held back your son,

your only one." 105

17. I will greatly bless you and will greatly multiply your seed, as the stars in the

heavens and as the sand on the shore of the sea, and your seed shall take hold of its

enemies'gate.

The results from Abraham's actions are emphatic ${ }^{106}$ blessings from God, including

the increase of his progeny that spills beyond the imagery of stars in Gen 15 to the sands

of the seashore. Initially seed (zera') is used in the multiple sense of one becoming many

103 The first angelic position of calling to Abraham from the heavens may not indicate haste, for after Abraham has finished sacrificing the ram on the altar, the messenger still chooses to remain out of sight, calling from the heavens with the final, elaborately longer speech. Why, in a narrative that highlights sight, does the divine messenger remain out of sight? Chapter four offers an interpretive covenant hypothesis that provides a possible reason for God's physical and visual distance during Abraham's test, see specifically fn. 106 on page 194.

104 This formula comes up in the later prophets (Isa 45:23, Jer 22:5; 49:13, Amos 4:2). Moses reminds God of the oath to the patriarchs where He swore by himself (Exo 32:13). The form qatal is used for the verb "I swear" where the "instantaneous action which, being performed at the very moment of the utterance, is assumed to belong to the past whereby the actor is, as it were, acting out his utterance. Hence this use of the perfect is sometimes called "performative." Joüon, Grammar, $\S 112 \mathrm{f}$, g. Doukhan adds the nuance that the perfect tense here indicates "completeness of God's swearing; it is definitive." Doukhan, Hebrew for Theologians, 119.

105 Joüon, Grammar, §170n.

106 The infinitive absolute followed by the imperfect (to bless I will bless) is used to emphasize the intensity and certainty of the statement- "I will certainly bless you." This can also be heard as affirmation or asserveration. Joüon, Grammar,§123e; Doukhan, Hebrew for Theologians, 122. 
offspring but the masculine singular mode is used for the seed gaining victory over his enemies. ${ }^{107}$

18. And all the nations of the earth will be blessed through your seed because you have listened to my voice."

The families or clans of the ground were mentioned in Abraham's first set of blessings in Genesis 12. Now the verbiage has shifted to nations of the earth blessing themselves ${ }^{108}$ through his seed, all because Abraham listened (obeyed) ${ }^{109}$ God's voice. 19. And Abraham returned to his lads, and they rose and went together to Beer-sheba, and Abraham dwelled in Beer-sheba.

As promised (v. 5), Abraham comes back to his servants, but alone. ${ }^{110}$ The next phrase, "they rose and went together" includes Abraham and his servants, ${ }^{111}$ who go to Beersheba where Abraham stayed.

${ }^{107}$ See Jack Collins, “A Syntactical Note (Genesis 3:15): Is the Woman's Seed Singular or Plural?" Tyndale Bulletin 48, no. 1 (1997). When Rebecca's family wishes her well on her departure to become Isaac's bride, two of these blessings were also commended to her. Gen 24:60 "Our sister, may you increase to thousands upon thousands; may your offspring possess [masculine singular verb] the cities of their enemies." Since the Book of Ruth reveals legal transactions were done at the gate (Ruth 4), gaining a hold of the enemies' gates implies dominating control of the city.

108 The hitpael form of the verb of blessing "conveys the idea of reflection, denoting a nuance of participation in the blessing." Doukhan, Hebrew for Theologians, 126.

109 When שםע, "hear" is followed by i⿱ form which "suggests that Abraham heard, obeyed completely." Doukhan, Hebrew for Theologians, 127.

110 The verb for returning is in the third person masculine singular form, "and he returned." The promise Abraham gave to the servants in verse 5 was clearly in the first person masculine plural form: "we will return." This discrepancy has raised speculation regarding Isaac's 'absence.' However, "Abraham stayed in Beer-sheba" also uses a masculine singular verb but is understood to include his encampment as a corporate unity. 


\section{Narrative Analysis}

'Between 'analyzed fragments' and 'larger views' is the 'literary middle ground'

of narrative art," says Alter. ${ }^{112}$ The art of a narrative is the creative telling of a story, the rhetoric $^{113}$ of the story. If a story is defined as "an account of characters and events in a plot moving over time and space through conflict toward resolution," 114 close reading of

${ }^{111}$ Here, the third person plural verbs are expected since they journey home as one group.

${ }^{112}$ Alter, Art of the Biblical Narrative, 17. Unlike the historical-critical source-oriented inquiry, narrative art requires a discourse-oriented analysis: "Looking to the text itself as a pattern of meaning and effect" and "making sense of the discourse in terms of communication, always goal-directed on the speaker's part and always requiring interpretive activity on the addressee's." Sternberg, Poetics, 15.

${ }^{113}$ Rhetoric is the art of effective or persuasive speaking or writing. On rhetorical criticism see the landmark article of James Muilenburg, "Form Criticism and Beyond," Journal of Biblical Literature 88, no. 1 (March, 1969), 1-18; Jim A. Kuypers, ed., Rhetorical Criticism (New York, NY: Rowman and Littlefield, 2009); Jack R. Lundbom, Bible Rhetoric and Rhetorical Criticism (Sheffield, UK: Sheffield Phoenix Press, 2013).

114 Gabriel Fackre, "Narrative Theology: An Overview," Interpretation 37, no. 4 (1983), 341. Aristotle defined a plot (muthos) as "the organization of the events." So, the story plot "'grasps together' and integrates into one whole and complete story multiple and scattered events, thereby schematizing the intelligible signification attached to the narrative taken as a whole." "Emplotment" imitates (mimesis) human action, intimating symbolic cultural significance to those actions, and presenting a way of being "within" time through temporal structure. Ricouer, Time and Narrative, x, 54-64. 
the rhetorical details imbedded in the text allow the story's intent ${ }^{115}$ to be heard through

its $o w n$ voice. ${ }^{116}$

An astute reader "hears" the voice of the text by scrutinizing how the literary

aesthetics in the Bible relate to each other and relate to the historiographic and

ideological functions of the particular narrative. ${ }^{117}$ Robert Alter offers a list of repetitive

narrative markers that link literary details to biblical ideology ranging from the "smallest

and most unitary elements to the largest and most composite ones": leitwort, motif,

theme, sequence of actions, and type-scene. ${ }^{118}$ Narrative theology recognizes that

115 "Bible texts address a directed goal which may rightly be identified as its author's intention, provided that intention is understood only 'adverbially." Recognizing authorial intent through careful analysis of the text's "directedness" or "intentional directedness" is a valid method of ascertaining authorial purpose. Thiselton, New Horizons in Hermeneutics, 560. Authorial original intent had been powerfully dismissed as a psychological standard for critically judging poetry in the noted article "The Intentional Fallacy" by W. K. Wimsatt and Monroe Beardsley who wrote, "We argued that the design or intention of the author is neither available nor desirable as a standard for judging the success of a work of literary art." Both did, however, admit, "In this respect poetry differs from practical messages, which are successful if and only if we correctly infer the intention." W. K. Wimsatt and Monroe C. Beardsley, "The Intentional Fallacy," in The Verbal Icon: Studies in the Meaning of Poetry (Lexington, KY: University of Kentucky Press, 1954), 3-18. In short, objective indicators of direction in the text has replaced the reader's intuitive presumptions regarding authorial intent, as a more stable locus of analysis.

${ }^{116}$ Ricoeur refers to this as an interpretation "through" the text. The temptation to impose unrelated, modern, western, secular filters prematurely on the Bible must be avoided. Barr recommends instead, "Let the Scriptures to speak to us in terms of themselves, and allow a synthetic approach to gather up the results of analysis. The resulting solidity and unity of the biblical teaching withdraws it from our control. In this situation the Word of God controls us, and presses upon us a deeper theological understanding of the Scriptures." Barr, Semantics of Biblical Language, 5-6.

${ }^{117}$ Sternberg, Poetics, 43. Coats categorizes the Aqedah in the genre of literary legend: "By definition legend functions as a narrative designed to edify subsequent generations by emphasis on virtues displayed by the central figure." He supports this by noting that in the telling of the tale, inner tensions are not shared, "God's character is not an issue. Isaac is relatively unimportant. Even Abraham's inner tensions carry no weight. The entire scope of the legend falls on Abraham's obedience." Coats, Abraham's Sacrifice of Faith, 397. Coats is commenting on the literary characteristics as he categorizes them. I will address the question of the historical reality of the Aqedah later in chapter 5 in the section: Ontology of the Aqedah Event, pages 306-310.

${ }^{118}$ Alter, Art of the Biblical Narrative, 95-96. Each marker will be defined in the footnotes as they 
narrative is "discourse about God in the setting of the story." 119 However, this section will try to limit theological discussion to brief implications from narrative analysis because the next level of meso-hermeneutics in the following chapter will focus on theology. The following dramatic analysis of the Aqedah will follow George Coat's delineation of narrative plot tension: exposition (Gen 22:1-2), execution of instruction (Gen 22:3-10), resolution (Gen 22:11-14), conclusion (Gen 22:15-18), and itinerary (Gen 22:19). ${ }^{120}$

\section{Exposition}

And it happened after these things that God tested Abraham. And He said to him, "Abraham!" and he said, "Here I am." And He said, "Take, pray, your son, your only one, whom you love, Isaac, and go forth to the land of Moriah and offer him up as a burnt offering on one of the mountains which I shall say to you."

With the temporal phrase 21 "it happened after these things," the narrator refers back to the sweep of Abraham's history as one collective unit and relates it to what

are identified in the narrative analysis.

119 "Truth" in the story setting is conveyed narratively by "depiction of reality, ultimate and penultimate, in terms of plot, coherence, movement, and climax." Insights gleaned can be organized around the three foci of narrative theology, "canonical story, life story, and community story. The first makes extensive use of literary analysis of biblical material, the second draws heavily on psycho-social resources in the exploration of personal experience, and the third is shaped by communal lore and the sedimentations of tradition." Fackre, Narrative Theology, 343; See also Gary L. Comstock, "Two Types of Narrative Theology," Journal of the American Academy of Religion 55, no. 4 (Winter, 1987), 687-717.

${ }^{120}$ Coats notes that unlike most tests, in the resolution, the original task is retracted and revoked (vv. 11-12a), yet Abraham is told he has passed the test (v. 12b), and the rest of the story hinges on the retracted test. Coats, Abraham's Sacrifice of Faith, 390-391. I do not agree that the test is retracted and will discuss the angel's prohibition of vv. 11-12 in chapter 4 on meso-hermeneutics, on pages 197-208.

${ }^{121}$ Surprisingly, this temporal marker is not tied chronologically to Abraham's age. The Abrahamic cycle is marked by " 13 explicit designation of times . . . The exceptional aspect of this string is that it consists of exact specifications of age, mainly pertaining to the hero and his wife." They are Gen $12: 4 ; 16: 3,16 ; 17: 17,24,25 ; 21: 5 ; 23: 1 ; 25: 7$, with the ages of Terah (Gen 11:32) and Ishmael (Gen 25:17) as bookends. But there are also notable gaps in the timeline. Fokkelman notes two significant time gaps (Gen 16:16-17:1 and Gen 21:34-Gen 22:1) in the cycle that refer to very important events for Abraham's two sons. The thirteen years of the first gap may suggest a similar length of time for the second gap. Isaac 
comes next. ${ }^{122}$ But the ambiguity of these things naturally elicits the query of which things? ${ }^{123}$ How far back should the reader remember? ${ }^{124}$ The previous chapter contained the birth of Isaac, a restoration of family priorities, establishment of political peace, property rights to a life-sustaining well, the rooting of a tree, worshipping God Eternal, and a settling down for "a long time in the land of the Philistines." Surely, the covenant journey has come to a blessed end with the number seven infused through this last event, what could possibly disturb the sense of peaceful narrative completion? ${ }^{125}$

is already weaned (3-5 years old) before the end of Genesis 21 , but when he reappears in the next story, Gen 22, he is suddenly about the age of two servants (na'ar suggests an age nearing the twenties), carrying wood up the mountain and asking astute questions. If the narrative gaps roughly correlate, tentative calculations would place him about 16-20 years old. J. P. Fokkelman, Reading Biblical Narrative: An Introductory Guide (Louisville, KY: Westminster Knox Press, 1999), 41-43. These are the kinds of insights derived from taking the preface phrase after these things to refer to the documented events of Abraham's life as a significant background for understanding the test that follows.

${ }^{122}$ In a literary manner, "with the narrator as interpreter, continuation and surprise begin the story." All of Abraham's previous trials and events are to be kept in mind, but a new twist is introduced. Trible, "Genesis 22," 171.

${ }^{123}$ Even before Abraham appears on the scene, the reader is hooked by the cryptic rhetoric of the narrator to ask questions. Rhetorically, "everything serves to 'summon' the reader to enter the world of the text." Thiselton, New Horizons in Hermeneutics, 481.

${ }^{124}$ Thematically, the Aqedah "is organically connected with the preceding chapter. Abraham has lost one son and now seems about to lose the other." Sarna, Genesis, 150. Martin Buber goes further and ties all seven of God's revelations to Abraham under the leitmotif of seeing culminating in the Aqedah: (1) Gen 12:1-3 — God will let him see the land, (2) Gen 12:7—“God also 'lets him see' Himself," (3) Gen 12:14 - "Again 'seeing' is mentioned, and now it is a matter of seeing the entire land," (4) Gen 15-Sees the heavens and given prophetic sight into the future, (5) Gen 17-God allows Himself to be seen, (6) Gen 18-Abraham looks up and sees God as a man standing by him (7) Gen 22-The hidden God sends Abraham to "see" the land, the place, the lamb (Isaac), then Abraham "lifts up his eyes and sees the ram. . . . God sees man and man sees God." Martin Buber, On the Bible, ed. Nahum N. Glatzer, trans. Harold Bloom (New York: Schocken, 1968), 37-43.

${ }^{125}$ Not only by artistic depiction, but through artful composition, the event that precedes the Aqedah is resonant with the number of completion and final wholeness - the number seven. "Each of the two names of the two principal characters, Abraham and Abimelech, occurs exactly seven times; there are seven ewe lambs; both the verb "to swear" (vv. 23 ff.) and the name Beer-sheba contain the same Hebrew stem as the word for "seven" (sh-v-')." Sarna, Genesis, 148. 


\title{
An unexpected thunderbolt_-“God [Elohim] ${ }^{126}$ tested Abraham.” More
}

\author{
emphatically, "God, indeed God, tested Abraham." 127 The privileged narrator ${ }^{128}$ discloses
}

the divine intent to the reader, bypassing Abraham, creating dramatic irony ${ }^{129}$ within the

\footnotetext{
${ }^{126}$ Six of Abraham's seven previous epiphanies were initiated by YHWH, not Elohim. This one is initiated by Elohim. This name, Elohim, links this narrative to two previous stories: the Abimelech incident in Genesis 20 shares common elements (Elohim in nocturnal communication with main protagonist, the threat of death, morally innocent yet culpable protagonist, God restraining the protagonist, return of victim, done this thing, see, fear of God), and the banishment of Ishmael in Genesis 21 holds even more similarities, see below:

“God orders Ishmael's expulsion (21:12-13) // God orders Isaac's sacrifice (22:2)

Food and water taken (21:14) // Sacrificial material taken (22:3)

Journey (21:14) // Journey (22:4-8)

Ishmael about to die $(21: 16) / /$ Isaac about to die $(22: 10)$

Angel of God calls from heaven (21:17) // Angel of the Lord calls from heaven (22:11)

"Do not fear" (21:17) // "fear God" (22:12)

"God has heard" // "You have obeyed (heard) my voice (22:18)

"I shall make into a great nation" (21:18) // "Your descendants will be like stars, sand," etc. (22:17)
}

God opens her eyes and she sees well (21:19) // Abraham raises his eyes and sees ram (22:13)

She gives the lad a drink (21:19) // He sacrifices ram instead of son (22:14)"

Wenham, Genesis 16-50, 99-100.

${ }^{127}$ Because of the definite article before God and the syntactical position of "God" before the verb here, Trible's translation powerfully conveys the certainty that this was a divine test. Trible, Coherence and Complexity, 171. This emphatic identification prescribes to God, and God alone, the responsibility for imposing this test. J. Davidson, "Abraham, Akedah and Atonement," 52.

${ }^{128}$ Alter explains the motif of the "omniscient narrator" as alluding to the epistemological status of the narrator who "is presumed to know, quite literally, what God knows, as on occasion he may remind us by reporting God's assessments and intentions, or even what He says to Himself." Alter, Art of the Biblical Narrative, 157; See also Wesley A. Kort, Story, Text and Scripture: Literary Interests in Biblical Narrative (University Park, PA: Pennsylvania State University Press, 1988), 41.

129 There are many kinds of irony. Dramatic irony is the situation where the audience knows something that the characters in a play or story do not. "Dramatic irony has a variety of functions, such as expressing criticism, stressing a shocking event or emphasizing a tragic situation, to name but a few." It may be that all of these functions coexist in the Aqedah. Shimon Bar-Efrat, Narrative Art in the Bible (New York, NY: T\&T Clark, 2008), 125. Situational irony is when there is a discrepancy between what is expected and what happens, e.g., Abraham's literal obedience is thwarted at the last minute by God. Verbal irony is the intentional use of words to mean something different from their literal meaning. Multiple forms of irony abound in the Aqedah. See Carolyn J. Sharp, Irony and Meaning in the Hebrew Bible (Bloomington, IN: Indiana University Press, 2009), 243. Even a historical form of irony continues in the 
very first verse: God, the narrator, and we know it is a test-Abraham does not. But we remain ignorant about what is behind the test: Why does God test Abraham? What kind of God needs to test humans? And what will happen if Abraham fails? The proffered verb test which sounds out the tie between the world of meaning above and below the text, suggests more problems than answers. ${ }^{130} \mathrm{We}$ may even wonder if the narrator knows but is purposely refusing to tell us. ${ }^{131}$ Hence, the overarching theme ${ }^{132}$ of a test affects both the reader and Abraham for the limits of our knowledge are made visible.

God initiates the test with a name "Abraham!" Then, there is an implied pause for Abraham's acknowledgment. That this opening dynamic is unusual is only seen if it is carefully compared to previous commands which are behind this text, ${ }^{133}$ for God always

historical employment of the religious Aqedah as a national trope by modern secular Zionism. Yael S. Feldman, Glory and Agony: Isaac's Sacrifice and National Narrative (Stanford, CA: Stanford University Press, 2010), 20.

${ }^{130}$ Trible, Genesis 22, 171.

131 "The omissions of biblical narrative are as cunning as its repetitions." Alter, Art of the Biblical Narrative, 98. The absence of Sarah, non-mention of Abraham or Isaac's inner thoughts or feelings, and omission of Isaac's name at the end all work to heighten the reader's sensitivity to the few details provided.

132 "It begins with a heading or statement of theme (v. 1a) which synthesizes what follows in a pregnant expression: God is testing Abraham." Westermann, Genesis 12-36, 354. "Theme. An idea which is part of the value-system of the narrative - it may be moral, moral-psychological, legal, political, historiosophical, theological - is made evident in some recurring pattern. It is often associated with one or more Leitwörter but it is not co-intensive with them; it may also be associated with a motif. (For example, the reversal of primogeniture in Genesis; obedience versus rebellion in the Wilderness stories; knowledge in the Joseph story; exile and promised land; the rejection and election of the monarch in Samuel and Kings.)" Alter, Art of the Biblical Narrative, 95. The theme of the Aqedah on which the moralpsychological-theological-ethical value system hinges is the concept of a divine test.

133 "Only this time does God address Abraham by name first—perhaps singling out the solemnity of this moment." J. Davidson, "Abraham, Akedah, and Atonement," 53. Francis Landy writes, "Primarily it also invokes Abraham as a speaking subject. The abstract distanced representation that encompasses the story (God - test-Abraham) is replaced by an Abraham who declares his presence and a voice that meets him." Francis Landy, "Narrative Techniques and Symbolic Transactions in the Akedah," in Signs and Wonders: Biblical Texts in Literary Focus, ed. J. Cheryl Exum, The Society of Biblical Literature Semeia 
started his verbal interactions with imperatives and self-assertions: (1) Gen 12:1 "Go,"

(2) Gen 12:7 “To your offspring, I will give," (3) Gen 13:14 "Lift up your eyes," (4) Gen

15:1 "Fear not," (5) Gen 17:1 "I am God Almighty," (6) Gen 18:5 "Do as you have said,"

(7) Gen 21:12 "Be not displeased." In striking contrast, God initiates this final test of

Abraham utilizing dialogue..$^{134}$

Why is this important for narrative analysis? Alter explains the significance of narrative beginnings, "From all I have said about the primacy of dialogue, several general rules suggest themselves for the alert reading of biblical narrative. In any given narrative event, and especially, at the beginning of any new story, the point at which dialogue first emerges will be worthy of special attention, and in most instances, the initial words spoken by a personage will be revelatory, perhaps more in manner than in matter, constituting an important moment in the exposition of character." ${ }^{135}$ In regard to matter, since this is the first time God calls him by his covenant name Abraham, God may have intended Abraham to take the test from a stance of self-awareness as the covenant Father

Studies (Atlanta, GA: The Society of Biblical Literature, 1989), 10-11.

${ }^{134}$ God did not verbally invite dialogue in Gen 15, where Abraham and God have their first recorded conversation. Abraham's protest started that conversation. Alter remarks on how revealing Abraham's first words to God are: “Until this point, all of Abram's responses to God have been silent obedience. His first actual dialogue with God-in this, too, prophetic precedents may be relevantexpresses doubt that God's promise can be realized: this first speech to God reveals a hitherto unglimpsed human dimension of Abram. . . . God remains impassively silent in the face of Abram's brief initial complaint forcing him to continue and spell out the reason for his skepticism about the divine promise." Alter, Genesis, 63 n2, 3.

${ }^{135}$ Alter, Art of Biblical Narrative, 74. 
of nations. ${ }^{136}$ In regard to manner, because the form was deliberately dialogical, it may suggest God's desire for Abraham to dialogue with Him during this test. ${ }^{137}$

Though Abraham's prompt response may seem a bit impersonal compared to his warm response to his son "Here I am, my son" and his previous addresses to God ("My Lord Yahweh" 15:2, 15:8, and "My Lord" 18:3), ${ }^{138}$ hinneni "Here I am" (literally "Behold, I") does communicate Abraham's open and willing attitude. It also introduces the Aqedah leitmotif (key-idea) of seeing which is referenced continually through related words of meaning or phonetic resemblance (hinneni, Moriah, eyes, saw, behold, see/provide, fearing) a total of thirteen times (Gen 22:1, $2[2 \mathrm{x}], 4[2 \mathrm{x}], 7[2 \mathrm{x}], 8,12,13$ $[2 \mathrm{x}], 14[2 \mathrm{x}])$. According to Alter, "it is one of the most powerful means for conveying meaning without expressing it." 139

\footnotetext{
${ }^{136}$ From the time God had given him the covenant name Abraham in Gen 17, God had used that name while talking to himself (Gen 18:17-19) but had never addressed Abraham by this covenant name until now (Gen 22:1).

137 There is one possibility that God may have set up Abraham for dialogue once before through body language in Gen 18:22. "It has been suggested that the phrase Abraham stood still before the Lord (18:22b) is a tiqun soferim 'scribal correction' to avoid irreverence, which would have been implied in the reverse sequence 'God stood before Abraham." Doukhan, Genesis, 248. If this is taken as true, it would depict a scene where two left for Sodom, but God remained behind and stood quietly in front of Abraham, creating a safe space for Abraham's reaction. Such a physical hint may have been taken by Abraham as an invitation to draw nearer to God to express his concerns, to negotiate and press for mercy (Gen 18:22). Alter, Genesis, 81. On the other hand, if Abraham was standing before the Lord in a humble but troubled attitude, God, who is sensitive to human emotions and expressions (See Gen 4:6) may have lingered behind to hear his servant's burden and waited for him to speak his mind.

138 The choice of context affects how one "hears" the text. How God and Abraham "heard" each other can only be determined from comparing present interactions with previous patterns and future repetitions. "The authors of the biblical narrative astutely discovered how the slightest strategic variations of the pattern of repetitions could serve the purposes of commentary, analysis, foreshadowing, thematic assertion, with a wonderful combination of subtle understatement and dramatic force." Alter, Art of Biblical Narrative, 91. It is certainly too early in the story to surmise Abraham's mood from his first response, except to note its brevity, but as the story progresses, his silence comes across as unusual.
}

${ }^{139}$ Alter, Art of the Biblical Narrative, 93. Leitwort is a root word that captures the smallest unit of 
By saying hinneni, Abraham invites God to visualize him as he presents himself

in readiness. The test reveals Abraham is consistently open and obedient. His triple

hinneni fulfills the criteria for a "sequence of actions"140 that marks the movement of the

plot. This also happens to be "Abraham's only response that is really a response:

hinneni." ${ }^{141}$

A horrific, yet artfully constructed command accosts Abraham's ears. Comparing

it to previous divine commands from Abraham's world of meaning behind the text helps

the reader to "hear" it as Abraham might have heard it, ${ }^{142}$ emotively, stylistically, and

"repetitive structuring and focusing devices in biblical narrative. . . Through abundant repetition, the semantic range of the word-root is explored, different forms of the root are deployed, branching off at times into phonetic relatives (that is, word-play), synonymity, and antonymity; by virtue of its verbal status, the Leitwort refers immediately to meaning and thus to theme as well. (For example, go and return in the Book of Ruth, the verb to see with its poetic synonyms in the Balaam story.)" Alter, Art of Biblical Narrative, 95. In the Aqedah, the leitmotif (key-idea) is seeing playing on the leitwort (key-word) ra'ah "to see" by extending to word-relatives either by meaning or phonetic resemblance: behold (hinneh), Moriah (if from either root ra'ah "to see" or yere" "to fear"), fear (yare). Bazalel Porten, "The Root Pair שוביבי in Jeremiah," in Hamlet on a Hill: Semitic and Greek Studies Presented to Professor T. Muraoka on the Occasion of His Sixty-Fifth Birthday, eds. W. Th. Van Peursen and M. F. J. Baasten (Leuven, Belgium: Peeters Publishers, 2003), 375-376.

140 "Sequence of Actions. This pattern appears most commonly and most clearly in the folktale form of three consecutive repetitions, or three plus one, with some intensification or increment from one occurrence to the next, usually concluding either in a climax or reversal. (For example, the three captains and their companies threatened with fiery destruction in 2 Kings 1; the three catastrophes that destroy Job's possessions, followed by a fourth in which his children are killed; Balaam's failure to direct the ass three times.)" Alter, The Art of Biblical Narrative, 95-96. In the Aqedah, the triple pattern of Abraham's hinneni to Elohim, Isaac, and the messenger of YHWH (Gen 22:1, 7, 11) marks the apices of the linguisticsyntactical chiastic structure. The only other candidate for this pattern in the Aqedah are the triple divine communications (Gen 22:1-2, 11-12, 15-18). The following subsection on literary structure will try to synthesize both sets of triple sequences in the structural analysis of the final form in the canon, see pages 144-153.

${ }^{141}$ Doukhan, "Center of Aqedah," 24.

${ }^{142}$ Variable repetitions is a narrative methodology that translates to the reader how a narrative character "hears" a new communication. These are under the direct control of the narrator. "What we find, then, in biblical narrative is an elaborately integrated system of repetitions, some dependent on the actual recurrence of individual phonemes, words, or short phrases, others linked instead to the actions, images, and ideas that are part of the world of the narrative we 'construct' as readers but that are not necessarily 
linguistically. Emotively, the test command moves pleadingly $(n a)$ in four steps from 'kinship, 'your son,' through the exclusivity of relationship, 'your only one,' through the intimacy of bonding, 'whom you love,' to climax in the name that fulfills promise, the name of laughter and joy, the name yishaq (Isaac)." ${ }^{143}$ This rhetoric inevitably elicits and intensifies Abraham's paternal feelings for his son Isaac, who is to accompany him on this journey. ${ }^{144}$ In stark contrast, God's previous command for Ishmael's banishment from Abraham (Gen 21:12-13) had rhetorically dampened Abraham's paternal attachment to his firstborn son: Ishmael wasn't named but referred to as "the lad" and Hagar as "your slavegirl" whereas Sarah and Isaac were prominently named, Ishmael was also called "the slavegirl's son" though the last mention of him in God's speech tied him to Abraham biologically as "your seed." Clearly, God's command rhetoric for relinquishing Ishmael was consistent with enabling relinquishment in matter and manner, but the command rhetoric regarding Isaac's sacrifice is unexpectedly paradoxical. ${ }^{145}$ Even the narrator chimes with God's rhetorical strategy by emphasizing Isaac's relationship to Abraham as

woven into the verbal texture of the narrative." Alter, Art of Biblical Narrative, 95.

143 Trible, “Genesis 22," 172. J. Davidson suggests the increasing specificity may be to avoid possible confusion since Abraham had previously suggested Ishmael and Eliezer as his heirs. J. Davidson, "Abraham, Akedah, and Atonement," 54. Licht argues that the serial delays in the tender phrasing increases dramatic tension. Jacob Licht, Storytelling in the Bible, 120.

144 J. Davidson, “Abraham, Akedah, and Atonement," 54-55.

${ }^{145}$ Many scholars interpret the tension between matter and manner as expressing divine empathy, i.e., God's tender words show that He recognizes how painful this request is for Abraham and the difficult magnitude of the test. Doukhan, Genesis, 276; Von Rad, Genesis, 239. The reverse would sound blasphemous, that God is intensifying the pain on purpose to magnify the test. Yet Kierkegaard will argue this very point because he believes it is giving up what one loves that defines a sacrifice. Kierkegaard, Fear and Trembling, 101. 
his son repeatedly; the narrator "does not miss a chance in the story to refer to Isaac as 'his son' and Abraham as 'his father' thus sharpening the edge of anguish that runs through the tale. ${ }^{{ }^{146}}$ Clearly, the son motif ${ }^{147}$ is a repeating element of relationship deliberately suppressed in Ishmael's banishment but clearly underscored in the Aqedah. Stylistically, the three increasingly specific designations of the divine command rhythmically parallel the three concentric designations in Abraham's initial call (Gen 12:1) suggesting a similar experience of sacrificial obedience. ${ }^{148}$ However, a new element is introduced, the first biblical mention of love ("whom you love") interrupts the sequence of biological, numerical, linguistic designation of the victim. Why does the test juxtapose love and sacrifice? Is this test about priorities (love versus sacrifice), Abraham's love for Isaac pitted against his love for God? ${ }^{149}$ Is it about constancy (love

\footnotetext{
${ }^{146}$ Alter, Genesis, 104n3. As in the story of Amnon and Tamar, "these terms serve to present the actions of the characters in the light of family relationships between them, thereby expressing an implicit judgment: either these actions are appropriate to these family relationships or they are not." Bar-Efrat, Narrative Art of the Bible, 245.

147 "Motif. A concrete image, sensory quality, action, or object recurs through a particular narrative; it may be intermittently associated with a Leitwort; it has no meaning in itself without the defining context of the narrative; it may be incipiently symbolic or instead primarily a means of giving formal coherence to a narrative. (For example, fire in the Samson story; stones and the colors white and red in the Jacob story; water in the Moses cycle; dreams, prisons and pits, silver in the Joseph story.)" Alter, Art of Biblical Narrative, 95. There are at least four motifs in the Aqedah: son, burnt offering, wood, and place.

148 "The three designations of the sacrifice Abraham was asked to offer ... parallel the three designations of the place he was asked to leave" in Gen 12:1. Doukhan, Genesis, 276.

${ }^{149}$ Levenson believes it is. For him, the Aqedah sacrificial command was in line with the ancient first fruit offering of the son to God, demonstrating obedience to God as a priority over love of progeny. Later, the firstborn was divinely ordered to be redeemed in Exod 13:13 and Num 18:15. Levenson, Death and Resurrection, 46-51.
} 
and sacrifice), requiring steadfast love for Isaac even as he obeys God to sacrifice him? ${ }^{150}$ Or is the test about engaging paternal love ("whom you love") to solve the sacrificial test command ${ }^{151}$

Linguistically, the lexeme ${ }^{152}$ of lek-lekha ("walk/go-for-yourself”) decisively links the God's first and last commands to Abraham together like bookends, for external journeys also connote an internal journey. ${ }^{153}$ Whereas the first lek-lekha commanded Abraham to leave his physical and religious past, the second lek-lekha "points to the future, his son Isaac and the land of Moriah, with all that it implies of hope and promise." ${ }^{54}$ Go to yourself, God says, once again, but this time take Isaac with you, and go "to the Land of Moriah and offer him up as a burnt offering on one of the mountains

${ }^{150}$ If pain is the "currency" i.e., the main value of a sacrifice, sacrificing the most precious item while continuing to love it would maximize the value of the act. Firstborn child sacrifice capitalizes on the love/pain of new parents.

${ }^{151}$ The ram as the test solution should align with the divine purpose behind the test command. The discussion about which of these solution paradigms is the correct one will be addressed in chapter 4 on theological meso-hermeneutics, see figure 4.5 on page 224.

${ }^{152}$ A lexeme is the small unit of lexicon in a language that bears meaning. It is one notion that may consist of one or more words with inflected meanings. As one word, they are the headings in a dictionary. As a phrase unit they carry one meaning, i.e., "take off," "put up with."

${ }^{153}$ Augustine says Abraham was given this test in order that "Abraham may discover himself; this testing is none other than a space offered to freedom, it is a way to fulfillment." Augustine quoted by Robert Davidson, The Courage to Doubt: Exploring an Old Testament Theme (Eugene, OR: Wipf and Stock, 1983), 50.

${ }^{154}$ Doukhan, Genesis, 276. Because the $ל$ of the "dativus commodi" can mean "to whose advantage (or disadvantage) something is done," is this second lek-lekha implying the mode of disadvantage to Abraham, as a bookend to the first usage? Perhaps that is ruled out by God's benevolent character, but then again, everything hinges on Abraham's response. 
which I shall say to you." 155 It would seem "as Abraham once broke with the past, so now he must destroy the future" 156 by offering it up in sacrifice.

The whole burnt offering ('olah) which requires everything except the skin to be annihilated in flames is repeated ominously six times in the test (Gen 22:2, 3, 6, 7, 8, 13). ${ }^{157}$ Doukhan writes, "Strangely and perhaps ironically, God's language in describing this human sacrifice, a Canaanite practice that was prohibited by Him (Lev 18:21; 20:2-5) and even called an 'abomination' (Deut 12:31), is the same as in the description of the tabernacle sacrifice (Exod 29:38-45; Lev 1:3; Num 15:1-10). The contradiction is even more disturbing as the two sacrifices express opposite theologies of salvation. While the pagan sacrifice implies the human ascent and work towards God, the Israelite sacrifice signifies, on the contrary, the divine descent and grace on behalf of humans." 158 Rife with rhetorical and ritual paradox, the test command ends with a divine promise to lead Abraham to the sacred place.

\section{Execution}

And Abraham rose early in the morning and saddled his donkey and took his two lads with him, and Isaac his son, and he split wood for the offering, and rose and went to

\footnotetext{
${ }^{155}$ As in the initial call, God promises continuing communication regarding the final destination. When Abraham had arrived at the tree of Moreh in Shechem after his initial journey, God visually appeared to him there and promised the surrounding land to his offspring (Gen 12:7). That became the site of Abraham's first altar in Canaan.

${ }^{156}$ Trible, "Genesis 22,” 173.

157 "The burnt offering was the only sacrifice that required the burning of the totality of the animal: 'The priest shall burn all on the altar as a burnt sacrifice' (Lev 1:9)." Adam and Eve, Abel, and Noah offered burnt offerings. Doukhan, Genesis, 285.

${ }^{158}$ Doukhan, Genesis, 277.
} 
the place that God had said to him. On the third day Abraham raised his eyes and saw the place from afar. And Abraham said to his lads, "Sit you here with the donkey and let me and the lad walk ahead and let us worship and return to you." And Abraham took the wood for the offering and put it on Isaac his son and he took in his hand the fire and the cleaver, and the two of them went together. And Isaac said to Abraham his father, "Father!" and he said, "Here I am, my son." And he said, "Here is the fire and the wood but where is the sheep for the offering?" And Abraham said, "God will see to the sheep for the offering, my son." And the two of them went together. And they came to the place that God had said to him, and Abraham built there an altar and laid out the wood and bound Isaac his son and placed him on the altar on top of the wood. And Abraham reached out his hand and took the cleaver to slaughter his son.

The first mention of chronological time in the Aqedah is Abraham's early morning preparations for the journey. ${ }^{159}$ Previously, Abraham's early rising was ensconced in safety as he observed the smoke of Sodom and Gomorrah from afar and witnessed the fading forms of Hagar and Ishmael disappearing into the wilderness from his campsite, but now it is he who must relinquish the safety of home to face death. ${ }^{160}$ Abraham's inner thoughts remain opaque but his actions are clear. Abraham's six preparatory verbs encircle his human companions with Isaac his son in dead center. ${ }^{161}$

Of Abraham's tasks, chopping is the only task vigorously accomplished (piel verb). Delaying this step to just before leaving camp sets up the already saddled donkey, 278.

${ }^{159}$ This time frame suggests the test command came during the previous night. Doukhan, Genesis,

${ }^{160}$ Abraham's early morning rising might be interpreted in various ways as a metaphor: for portending something ominous, demonstrating prompt obedience, perhaps troubled anxiety, deliberately maximizing secrecy, or as Abraham's acquired habit (Gen 19:27, 21:14).

161 Trible, "Genesis 22," 173. It was noted in the grammatical section that Abraham is the sole subject (masculine singular) of all six verbs (rose, saddled, took; cut, arose, went). Possible reasons for his exclusive activity are: Abraham is the sacrificial priest for his family, he understood God command as a personal ordeal, the ordeal may end in Isaac's funeral, his obedience attests to his singlemindedness toward God, he is communicating through body language to God. 
two lads, Isaac, and God as the captive audience to the intense dismembering of the wood. If this sequence of saddling the donkey before chopping the wood seems odd, it is because the reader is drawing from the world of meaning in front of the text - the reader's experiential knowledge of how wood is usually taken on a journey. Usually, the order is in reverse: first chopping the wood, then binding it, then packing it with other items onto the transporting entity. Karen Wacome therefore, interprets this unusual sequence of Abraham's actions as a deliberate double-voiced silent protest, a speech-act ${ }^{162}$ communication to induce God to relent. With each shattering stroke Abraham "presents the deity with a preview of the violence that will be done to Isaac if the sacrifice is completed." 163

Other theological undercurrents may reside in the narrator's handling of wood in the Aqedah test of worship. Of all the sacrificial implements, it is wood (5x), not knife

162 A "speech-act" is an utterance or action that conveys a meaning beyond a basic descriptive or propositional function. This is referred to as a performative, illocutionary act. John Langshaw Austin, How to Do Things with Words (Cambridge, MA: Harvard University Press, 1975), 52, 148. Bahktin recognized discourse could be nonverbal. "To live means to participate in dialogue; to ask questions, to heed, to respond, to agree and so forth. In this dialogue a person participates wholly and throughout his whole life: with his eyes, lips, hands, soul, spirit, and with his whole body and deeds. He invests his entire self in discourse, and this discourse enters into the dialogic fabric of human life, into the world symposium." Mikhail Bakhtin, Problems of Dostoevsky's Poetics, trans. Caryl Emerson (Minneapolis, MN: University of Minnesota Press, 1984), 293. Abraham's chopping of the wood may be interpreted by the servants and Isaac as routine preparation for a sacrifice, but because God and the reader are privy to what prompted it, subtle deviations from the expected norm (such as delaying the task until the end, unusual intensity of the chopping) can be understood to indicate confusion, reluctance, or even protest.

${ }^{163}$ Karen Ann Halvorsen Wacome, "Watching the Sacrifice of Isaac: Bahktin, Dialogism and Genesis 22:1-19" (PhD dissertation, Graduate Theological Union, 2005), 106. Others also recognize the drama of this foreboding action. "Each blow must be felt as compounding the murder." Landy, "Narrative Techniques," 13. "In a narrative famous for its rigorous economy in reporting physical details, this act of Abraham, wielding an axe and cutting things apart is ominously singled out for attention." Alter, Genesis, 104. 
$(2 \mathrm{x})$, fire $(2 \mathrm{x})$ or altar $(2 \mathrm{x})$, that is mentioned most frequently. Wood is a recurring motif of the Aqedah. But why would such a mundane substance be given prominence? One narrative possibility reaches back to the world of meaning behind the text, the strange detail of a tamarisk tree Abraham planted after obtaining well-rights in Beersheba, just two verses before the Aqedah (Gen 21:33). Tamarisk trees have high water consumption and in ancient times were the sacred wood preferred for making divine images and known therefore as the "muscle and bone of the gods." 164 Was this tree mentioned because it was a source of wood for the offering? Even if the connotation of wood with idolatry existed only in the minds of the intended Israelite audience in the world in front of the text, a subtle polemic against wooden idols and grove worship can be plausibly educed by the narrative arc from Abraham's first sacrifice ${ }^{165}$ at the sacred Tree of Moreh to his final sacrifice on Mt. Moriah where trees are reduced to transported fodder. ${ }^{166}$ If this hunch is correct, it might explain why this motif of wood is redundantly tagged in the

\footnotetext{
164 Thorkild Jacobsen, “The Graven Image," in Ancient Isrealite Religion: Essays in Honor of Frank Moore Cross, eds. Paul D. Hanson, Patrick D. Miller Jr., and S. Dean McBride (Philadelphia, PA: Fortress, 1987), 25.

${ }^{165}$ Abraham's life journey is marked by altars, Isaac's by wells, and Jacob's by stone memorials.

${ }^{166}$ Trees were prohibited within the confines of the tabernacle because of their association with idolatry. "You shall not plant any tree as an Asherah beside the altar of the Lord your God that you shall make" (Deut 16:21). Gideon was told to cut up an Asherah pole and use it as wood for a burnt offering to Jehovah (Judg 6:26).
} 
Aqedah with the phrase "of the offering." Wood is for offerings to God; trees are not gods to worship.

Thus far, two of the test imperatives (take, go) have been completed, Abraham "took... Isaac, his son" and "went to the place of which God had told him." Only the last imperative of sacrifice remains. ${ }^{167}$ It is not clear whether the perfect tense (had told) of the verb amar (to say) in verse 3 implies directions were given to Abraham after verse 2 (which I shall tell you) or whether if that phrase functions only as a rhetorical tag for the first mention of the place as told to Abraham. ${ }^{168}$ What is clear is the concept of the place (vv. 2, 3, 4, 9, 14) becomes increasingly important as the Aqedah progresses. It will remain as one of the lasting religious legacies of the Aqedah.

These four narrative motifs hint at the realms of relationship (son), ritual (burnt offering), things (wood), and space (sacred place). Time, which had been the regular descriptive benchmark for the Abrahamic cycle is the one realm missing from the list. ${ }^{169}$

${ }^{167}$ Gen 22:2.

${ }^{168}$ According to Wenham, "The last clause indicates that God had spoken again to Abraham, for the location of the mountain was not revealed at first." Wenham, Genesis 16-50, 106; cf. Westermann, Genesis 12-36, 358.

169 The Aqedah does not disclose the age of Abraham or Isaac. Instead, the framing temporal marker gathers everything that has happened prior to this event into one phrase "after these things," the next temporal marker in the story "early the next morning" relays obedient preparations, the following temporal marker "on the third day" catapults the reader to the day of the sacrifice, and the last temporal marker is implied by "Abraham dwelt in Beersheba." 
In contrast to being so overt in previous events, in the Aqedah, time is used subliminally to affect the reader.

For instance, the temporal marker "on the third day" alerts the reader to a missing two-day gap. Auerbach imaginatively fills this temporal vacuum with existential dread, "Thus the journey is like a silent progress through the indeterminate and contingent, a holding of the breath, a process which has no present, which is inserted, like a blank duration, between what has passed and what lies ahead, and yet which is precisely measured: three days! Three such days positively demand the symbolic interpretation which they later received." "170 The skip over two days is followed, per contra, by a wordy description of a single instant: "Abraham lifted up his eyes and saw the place from afar." ${ }^{171}$ Though it is tempting and often necessary for narratologists to fill in time and verbal gaps, ${ }^{172}$ this should not rise to the level of disregarding the explicit temporal staging by the narrator. The curt reference of two days of narrated time indicates the content of those days as unimportant to the plot except, perhaps, as a symbolic duration,

${ }^{170}$ Auerbach, Mimesis, 10.

171 The narrator could have written, "On the third day, Abraham saw the place" to state the same fact. The phrase "Lifting up of the eyes and seeing" seems to be metaphor for meaningful recognition. Compare Gen 13: 10 "Lot lifted up his eyes and saw the Jordan Valley, that it was well watered like the garden of the Lord." Lifting of the eyes does not always mean he looked up because Lot's gaze is geographically downward, toward the Jordan valley. The metaphor relayed an apperception of verdant land reminiscent of the Garden of Eden.

172 The pervasive silence that surrounds Abraham's journey could be interpreted as dread, numbness, confusion, fear, or anxiety. God's presumed silence during the three-day journey has also raised speculation about divine emotions. Filling in gaps is extremely dependent on context and because it invites projection and speculation, reveals more about the interpreter's personality than anything else. Is there something more objective in the text to interpret the silences? 
while the stretching of narration time highlights Abraham's moment of sight as very significant to the plot of spiritual sight. ${ }^{173}$ The relation between narration time and narrated time, a technical relationship residing between the text and the reader in front of the text, reveals the underlying priorities of the narrator, who anticipated the reading performance from the world behind the text. ${ }^{174}$

With the place in sight, Abraham also commands his servants through four verbs, just as God did: "[You] Stay for yourselves," "[we] will go," "[we] will worship", "[we] will return." 175 The Hebrew ל dativus commode-reflexive here (as in the lek-lekha "walk for yourself" of the divine imperative to Abraham), comes across as "Sit for yourselves, sit for your own sakes." Note how Abraham skillfully emphasizes their benefit in resting here and ends with a reassuring promise to return to them. Abraham's rhetorical mastery continues in recognizing Isaac's dual identity as a "lad" among other lads and as part of "we" with himself. ${ }^{176}$ Finally, a hint of self-effacing humor may be tucked away in the

${ }^{173}$ Narrated time is literary time inside the story. Narration time is the objective, external "time required for telling or reading the narrative." The longer the narration time relative to narrated time, the more important it is in the author's eyes. Bar-Efrat, Narrative Art of the Bible, 143.

174 "If we note variations in narrated time in relation to narration time, ranging from scenic representation to summary account, we will discover the narrative's focal points and the relative importance of its various subjects." Bar-Efrat, Narrative Art of the Bible, 151.

${ }^{175}$ God's test command also had four verbs: "[you] Take," "[you] Go for yourself," "[you] Offer," "I will tell you." Verbal comparisons are: Opposites_-"Take your son/Stay with the donkey," Parallel"Go/Go," Interpretive_-"Offer him up/Worship," Continuity_-"I will tell you/We will return to you."

176 "An identity of terms, an ironic divergence of meanings - the young men who are his servants - in fact, his slaves - and the boy to whom he fondly refers, whom he thinks he is going to kill." Alter, Genesis, 104. Trible dissects the designations of Isaac, meticulously pointing out that "we" stands for bonding between father and son, but the distancing term "lad" unites Isaac with his companions. According to Trible, attachment-detachment is a "dangerous dialectic" that is about to be "transcended in the worship of God." The ideal is "non-attachment." Trible, "Genesis 22," 179. Her explanation is: "Nonattachment is a transcendent way of knowing and thinking. It moves human beings beyond interpersonal entrapments to a 
literary chiasmus ${ }^{177}$ of his nouns, "Wait you here with the ass and $I$ and the boy will go to here." ${ }^{178}$ Abraham juxtaposes himself with the donkey; a chiastic comparison can suggest either similarity or contrast. ${ }^{179}$

When Abraham shares his intention to go with his son to worship and return together to the traveling party, the reader may wonder if this is a speech of hope, faith, confusion or deception. ${ }^{180}$ Though the dramatic irony at the beginning of the Aqedah

realization of the divine. Thus it offers a spiritual perspective that allows one to be in the world but not of it. In the language of Genesis 22, nonattachment is fear of God. In addition to scriptural foundations, this interpretation builds on Zen Buddhism and Metapsychiatry." Ibid. fn. 20. Another possibility for understanding the concept of non-attachment is to consider the psychological concept of differentiation that avoids enmeshment and blurring of boundaries. Differentiation is the ability to be distinct, unique while remaining in healthy relation to a larger group or family. This is also referred to more broadly as "fieldindependence" in psychology, a cognitive style where one can choose to be independent or distinct from their backgrounds or context without rejecting it. Oxford Dictionary of Psychology, $4^{\text {th }}$ ed. (2015), s.v. "Field Dependence-Independence." In any case, the journey holds the intimation of a rite of passage for Isaac, a coming of age from a dependent child to a semi-autonomous young adult and spiritual heir.

${ }^{177}$ A chiasmus is a rhetorical or literary figure in which words, grammatical constructions, or concepts are repeated in reverse order in the same or modified form. Oxford Dictionary of English, s.v. "chiasmus."

178 "Chiasmus can also be developed in precative discourse between verbs of different kinds. In Ge 22:6 an ethical object stands in chiasmus with a subject, 'wait you here with the ass and I and the boy will go to there." Andersen, The Sentence in Biblical Hebrew, 134.

${ }^{179}$ Abraham and the ass are the only two laden down with a burden, the lads and Isaac are free and oblivious.

${ }^{180}$ Early Church Fathers, like Origen recognized there were two ways to interpret Abraham's speech here and reasoned "that in order to save Abraham from being an outright liar, we must assume Abraham thought both that he would fulfill God's command and that they would both return; and the only way to resolve this patent contradiction would be for Abraham to have believed his son would be resurrected.” Stephen R. Palmquist and Philip McPherson Rudisill, "Three Perspectives on Abraham's Defense against Kant's Charge of Immoral Conduct," The Journal of Religion 89, no. 4 (October 2009): 467-497. The world of meaning behind the text, of previous chapters in Genesis, demonstrates Abraham's habit under stress has been of half-truths to mislead hearers (Gen 20:11-13); the world of meaning in front of the text, as explicated by the book of Hebrews (Heb 11:19), says Abraham's faith in the miracle of resurrection may be behind this utterance. These options for interpretation will be discussed in the next chapter on the level of meso-hermeneutics. 
initially elevated the reader above the narrative characters by the privileged knowledge that this was a test, at this juncture the reader is more confused about Abraham's thoughts than even his own servants who accept his words at face value. Ironically, privileged knowledge reads ambiguity into an otherwise straightforward proposition. ${ }^{181}$

The last leg of the journey requires a second preparation and a second departure. ${ }^{182}$ "This time the objects, wood of the burnt offering and fire and knife, surround 'Isaac his son.' Ironies abound. Isaac carries the wood that will ignite him. Yet unkindled it is not dangerous material, unlike the fire and the knife that Abraham takes in his own hand. The father embraces his son with potential destruction even as he protects him from immediate danger. Syntactically and thematically this sentence echoes verse three to trap Isaac." ${ }^{183}$ The depiction of a doomed son under wood evokes the image of Ishmael under a woody bush in the previous chapter. ${ }^{184}$ Whatever is keeping the wood

181 The irony of deeper knowledge causing confusion hinges on the documented moral character of Abraham. Abraham is faithful, but in speech he has been misleading to others without outright lying. Thus, the reader is not sure how to understand him here. Is this remark a statement of faith, hope, a lie, or a half-truth (Isaac could return as burnt ashes for burial)? At this point in the test there are at least seven different levels of seeing/knowing the truth: God, the narrator, Abraham, Isaac, the servant lads, the donkey and the reader. The last entity is the most confused, even more confused than Abraham's ass.

182 Westermann, Genesis 12-36, 359. The first departure was from the physical home encampment. The second departure is from society altogether. The first separated Isaac from his protective mother, the second separates Isaac from his peers. The public personae of father and son have been left behind, only a private bond remains between these two. It will now be tested.

183 Trible, “Genesis 22," 175.

${ }^{184}$ From under the bush, Ishmael cried out to God though we don't know what he said. God heard him then saved him through his mother and a well (Gen 21:17). From the same position relative to wood, Isaac speaks for the very first time as well. At this point in the story, Isaac has assumed the duties of the beast of burden, but unlike a dumb animal Isaac has a voice and a deductive mind and will call on his father to answer. 
together is not mentioned ${ }^{185}$ and even Isaac's back for carrying the wood is not

mentioned. What is specifically highlighted is Abraham's hand. Notably, it is Abraham's hand, not the dangerous cleaver in it, that is the focus of the angelic prohibition later. ${ }^{186}$

Thus laden with the implements of sacrifice, father and son "went, the two of them, together." ${ }^{187}$ This tender inclusio $^{188}$ of solidarity in solitude envelopes the central dialogue of the Aqedah.

When Isaac finally speaks, the Hebrew is literally "and Isaac said to Abraham his father, and he said, "My father!" 189 Doukhan writes, "It is the first and only time that Isaac speaks in this story. In the Hebrew text, the first 'say' of Isaac is not immediately followed by the words of Isaac. It is as if Isaac intended to say something but stopped and could not proceed. This detail, overlooked in most translations, suggests Isaac's distress. He is full of contradictory thoughts and overwhelming emotions." ${ }^{190}$ Alter's rule that the

${ }^{185}$ Only later do we hear about the binding of Isaac, looking back, we may assume that a binding material was probably holding the wood together for transport by Isaac. In the narrative called the Aqedah (the Binding), the verb bind is found but there is no mention of the material used.

186 The angel of Elohim commands Hagar to hold Ishmael by the hand firmly in order to save him (Gen 21:18). The angel of YHWH commands Abraham to withdraw his hand from the lad, to save Isaac (Gen 22:12). The parental hand is the focus of the angel of YHWH for saving the child.

${ }^{187}$ Sarna depicts the poignant atmosphere in the phrase, "There is perfect rapport between the two, encompassed as they are in mutual solitariness and enveloped in silence. The tension between the unsuspecting innocence of the son and the unuttered agony of the father does not disturb the harmony." Sarna, Genesis, 152.

${ }^{188}$ An inclusio is a refrain that occurs only twice, delineating a unit of text by enclosing it in the middle. Dictionary of the Old Testament, s.v. "Inclusio."

189 Doukhan, Genesis, 279-280.

${ }^{190}$ For a masterful exposition of the whole dialogue see Doukhan, Genesis, 280. Efrat also sees this as "irresolution, perhaps nervousness. Isaac wants to ask the question which is bothering him ("Where is the lamb for the burnt offering?), but he is unsure, begins speaking, then hesitates." Bar-Efrat, Narrative 
manner of a character's first speech is revelatory of character rings true, for Isaac is later portrayed as habitually delaying confrontation, ${ }^{191}$ as hesitant yet trusting, ${ }^{192}$ and as weighing sensory information carefully before forming a conclusion. ${ }^{193}$ Here Isaac breaks through his natural reticence and calls on Abraham as "his own unique and loving father." 194

Abraham tenderly replies, "Here I am, my son." This paternal response, human father to human son, marks the exact apex of the literary center of the Aqedah. ${ }^{195}$ Flanked by Abraham's two other hinneni responses to God, it differs from them only by ending with "my son." 196 Landy hears in this phrase Abraham's consistent readiness "to answer questions, at his disposal, kindly, attentive. This willingness is also protective: he will attempt to dispel doubt, satisfy curiosity and consequently anxiety, lend a tolerant and essentially comforting ear." ${ }^{197}$ As the literary center of the Aqedah, this paternal response

Art in the Bible, 45.

${ }^{191} \mathrm{He}$ 's waited three days to bring up the missing item to his father. He later avoids confrontation over wells yet keeps a sharp memory of past wrongs when Abimelech comes to make a treaty (Gen 26:1527).

${ }^{192}$ Isaac asks Jacob, "Who are you, my son? . . . How is it that you have found it so quickly, my son?" Gen 27:18-20.

${ }^{193}$ Isaac deliberates sensate evidence before choosing to believe, "The voice is Jacob's but the hands are the hands of Esau." Gen 27:21-27.

${ }^{194}$ Landy, "Narrative Techniques," 16. Landy elaborates further, "Here, Abraham's universal role as father of nations has receded into the background, Isaac relates to Abraham as 'my father, my only father, whom I love, Abraham.' Each is utterly irreplaceable to the other."

${ }^{195}$ Doukhan, "Center of the Aqedah," 19.

196 This ending tenderly matches the possessive cry of Isaac, "My father!"

${ }^{197}$ Landy, "Narrative Techniques," 16. Davidson reads it as indicative of intensity. J. Davidson, 
either is, or points to the central meaning of the Aqedah. Crenshaw writes, "Indeed, one could even say that the heart of the story lies in just two (Hebrew) words within the dialogue: Dad/my son." 198

Son and father share patterns of verbal sequence and rhyme. Landy compares them, "Abraham says to his lads, 'Stay here (פה) with the ass, and I and the lad will go thither (עד כה)' (v 5). Isaac says, 'Here (הנה) are the fire and the wood, but where (איה) is the lamb for the burnt offering?' (v 7)." 199 For Abraham, the place beyond will divulge the final answer when Isaac, the unaware victim here finally reaches there. For Isaac, the unspoken reality of what awaits there may be starting to sink into the space here between his father and him: "This is another way of defining the terrible reality, without having to explicitly state: 'Am I the lamb?'”200

Instead of responding with spatial locator hinneh (behold/here) for the lamb's whereabouts, or hinneni “Behold, I,” Abraham's habitual answer to all questions (vv. 1, 7, 11), ${ }^{201}$ Abraham focuses the answer on God, "God will see (for) Himself, the lamb for the burnt offering, my son." The emphasis syntactically points to God ${ }^{202}$ as the solution;

\footnotetext{
"Abraham, Akedah, and Atonement," 59. Westermann hears in it a "readiness to listen" that functions by making it "possible to introduce the dialog with the mutual exchange: 'my father' - 'my son' (v.7a)." Westermann, Genesis 12-36, 359.

${ }^{198}$ Crenshaw, Whirlpool of Torment, 29.

${ }^{199}$ Landy, "Narrative Techniques,” 26.

${ }^{200}$ Doukhan, Genesis, 280.

${ }^{201}$ Doukhan, "Center of Aqedah,” 23.

${ }^{202}$ God as the subject precedes the verb, a reversal of usual Hebrew order, thus syntax emphasizes
} 
"He throws the ball back into God's court, so to speak: 'God will provide.' At this

moment there is still an opening left to God. One must note, however, that the statement has this meaning, and is possible, only in dialog." ${ }^{203}$

Is this dialog exclusively between the human participants? The speaking pattern evokes the first dialogue between God and Abraham: Isaac calls, "my father!" and God had called "Abraham! (Father of Nations)," Abraham answered to both "hinneni," Isaac's question has three objects and God's command has three designations, the endings of both utterances overlap on one identity, Isaac is the lamb. If Abraham's answer to Isaac is an indirect address to God, would it be too farfetched to surmise that God was using Isaac to provoke dialog with the taciturn Abraham?204 God is testing Abraham, is Abraham testing God?205 Abraham's solicitous answer to Isaac "comes close to the solution, only

the subject, God.

${ }^{203}$ Westermann, Genesis 12-36, 359. Hope, prophecy, prayer, evasion, kindness, irony, faith have all been proffered for Abraham's motive behind this enigmatic answer. "The idiomatic force is 'provide,' but God's seeing lines up with Abraham's seeing the place from afar, his seeing the ram, and the seeing on the Mount of the Lord. Beyond the tunnel vision of a trajectory toward child slaughter is a promise of true vision." Alter, Genesis, 105; J. Davidson, “Abraham, Akedah and Atonement," 59; Doukhan, Genesis, 280; Landy, "Narrative Techniques," 17; Von Rad, Genesis, 241; Wenham, Genesis 16-50, 109.

${ }^{204}$ Was God and Abraham in what can be framed as a custody battle, with the naïve Isaac as proxy for communicating indirectly? This possibility is brought up by Abraham's history. Abimelech may have been used by God as proxy to publicly chastise Abraham's lack of moral integrity over Sarah's complete identity (Gen 20).

${ }^{205}$ There is a Jewish tradition of reading the Akedah as a test turned on its head with Abraham testing God's own fidelity to the covenant and to His divinely provided son (Gen 21:1-2). Lippman Bodoff, “God Tests Abraham, Abraham Tests God," Bible Review 9, no. 5 (October, 1993): 53-56, 62. 
then to break off and leave both again to their thoughts." ${ }^{206}$ Abraham and Isaac walk on, together. ${ }^{207}$

When they arrived at the place "of which God had told him," Abraham embarks on the final preparations ${ }^{208}$ as the sole actor of six verbs that target Isaac at the end of each triplet (built, arranged, bound Isaac his son, set, sent, took, to kill his son). ${ }^{209}$ After Isaac is bound and lying over the wood $^{210}$ of the altar, the visual scope narrows to one aged hand, time slows down to one moment, one simple gesture is stretched out in

206 Von Rad, Genesis, 241.

207 This inclusio "the two of them walked together" has not changed from verse 7, but the participants have - they are now gripped by new thoughts. Efrat calls this particular phrase a linguistic motif: "On occasions it is not a single word which is repeated but an entire phrase or a sentence within a narrative or a series of narratives, constituting a (linguistic) motif. Repetition of this kind may be verbatim or may evince slight changes, and both the actual repetition and modifications are important in reflecting the similarity of difference between situations, in describing characters, in emphasizing a topic or a concept, etc. So they went both of them together (Gen. 22.6, 8).” Bar-Efrat, Narrative Art in the Bible, 215.

208 The sacrificial preparations through six verbs have been interpreted in opposite ways by narratologists. Coats reads it as a fast run up to the climax, "Following this transition, however, no further delays in the pace of narration appear. With rapid pounding verses 9-10 report construction of the altar, preparation of the wood, and the final order for slaughter that would end the son's life in sacrifice." Coats, "Abraham's Sacrifice of Faith," 394. Alter reads it as a slowing of time, "In contrast to the breathless pace of the narrative as a whole, this sequence inscribes a kind of slow motion: building the altar, laying out the wood, binding the child on top of the wood, reaching out the hand with the butcher knife- until the voice calls out from the heavens." Altar, Genesis, 105. The difference may reside in whether one views the glut of verbs as action-packed haste or as one important task unbundled then conveyed in overly minute detail. Bar Efrat's maxim of narrated time vs narration time would mark this activity as important to the plot.

209 Trible, "Genesis 22," 177. Davidson points out that we are never told when Abraham tells Isaac about the command, but by the time of binding "Isaac had to know." J. Davidson, "Abraham, Akedah, and Atonement," 60. The order for the Aqedah sacrifice (bind, lay on non-burning altar, slaughter) is not the same as for animal burnt offering (slaughter, splash blood, skin the animal, cut into pieces, lay pieces on burning altar, Lev 1:1-17). Perhaps Abraham is delaying the slaughter to the last moment, perhaps the customary order for human sacrifices is different. In either case, Abraham is very strong to pick up a bound young man to lay him on the altar.

${ }^{210}$ Ishmael was lying under the wood of the bush (Gen 21:15), Isaac had been under the wood initially (Gen 22:6-8) but is now lying over the wood on the altar (Gen 22:9). 
narrative time into two predicative clauses and the knife that Isaac had carefully ignored until now, reappears; "Abraham stretched out his hand and took the cleaver." Into this awful suspense, the narrator who divulged God's intentions now grants the reader one, and only one peek into Abraham's hidden intentions. Abraham took the cleaver with the resolute intent "to slaughter his son." 211

\section{Resolution}

And the Lord's messenger called out to him from the heavens and said, "Abraham, Abraham!" and he said, "Here I am." And he said, "Do not reach out your hand against the lad, and do nothing to him, for now I know that you fear God and you have not withheld back your son, your only one, from Me." And Abraham raised his eyes and saw and look, a ram was caught in the thicket by its horns, and Abraham went and took the ram and offered him up as a burnt offering instead of his son. And Abraham called the name of that place YHWH-yireh, as is said to this day, "On the mount of the Lord, there is sight."

The sense of timing is absolutely sure in the Aqedah. A piercing cry from the heavens halts the near-death in the wilderness ${ }^{212}$ with "Abraham! Abraham!"213 Just as

${ }^{211}$ Had the narrator not divulged his intent, Abraham's actions could have been interpreted other ways, such as acting out required motions while hoping for a reprieve, or taking up the knife to fling it away in rejection of the command or taking up the knife to release Isaac's bindings. Instead, the narrator reveals Abraham's uncompromising homicidal intent. Ironically, Abraham who was always afraid that he might be killed violently (Gen 12:12; 20:11) is willing to enact the role of executioner over his trusting son.

212 Near-death trial in the wilderness is a type scene identified by Robert Alter that marks the stories of Ishmael and Isaac in Gen 21-22. Along with the Leitwort, a type scene is a "distinctive biblical literary convention." Alter, The Art of Biblical Narrative, 96. See also Robert Alter, "How Convention Helps Us Read: The Case of the Bible's Annunciation Type-Scene," Prooftexts 3, no. 2 (1983):116-117. “A biblical type-scene is a narrative unit with numerous literary characteristics that are presented in a narrative pattern generally common to other similar passages but with key modifications. The characteristics of a well-developed type-scene include a combination of key terms and phrases, aspects of plot development and theme, and character actions and behaviors. While some of these elements may be common to many narratives throughout the biblical text, a good presentation of a type-scene highlights a collection of characteristics that distinguishes the narratives of the type-scene from all other passages." Marina Hofman, "Dream Type-Scene in Old Testament Narratives: Structure and Significance" (PhD dissertation, University of St. Michael's College, 2014), 4.

${ }^{213}$ Name repetition can convey emotive passion or emphasis. Trible sees the added purpose of the 
the messenger of Elohim rescued Ishmael, ${ }^{214}$ a messenger of YHWH rescues Isaac.

Abraham answers in his usual manner, "Here I am." 215

Abraham's reaching his hand toward the lad is prohibited ${ }^{216}$ and his inner intent

"to kill his son" is categorically condemned ${ }^{217}$ by "do nothing to him!" The tension of fear

is broken, the bound victim is released, but instead of lingering on the happy scene the

narrative focus immediately shifts upward into the eternal recesses of God's knowledge.

"For"218 now I know that you fear God because you have not withheld your son, your only

repetition here as urgent "diversion, to compel a response." Trible, "Genesis 22," 178. Usually context determines how it should be interpreted, see Gen 46:2; Exod 3:4; 1 Sam 3:10; 2 Sam 19:4; Matt 7:22, 23:37, 27:46; Luke 10:41, 22:31; Acts 9:4.

${ }^{214}$ Gen 21:11.

${ }^{215}$ This interruption may be unexpected to most readers, but Abraham's answer of constancy suggests that a divine interruption may have been anticipated.

${ }^{216}$ The first reaching out of Abraham's hand was to take the knife. Had Abraham reached out his hand again, but this time toward the lad with the knife in his hand? Doukhan believes the second movement is the one indicated by the angelic words. Doukhan, Genesis, 283. The ESV translates the angel's words as "Do not lay your hand on the lad or do anything to him."

${ }^{217}$ The second prohibition is a synthetic parallelism which enlarges to ban everything harmful to Isaac. William Brown, "Psalms and Hebrew Poetry," in Cambridge Companion to the Hebrew/Old Testament (Cambridge, UK: Cambridge University Press, 2016), 255-257; Wenham, Genesis 16-50, 110; Westermann thinks the second prohibition draws retrospectively from the span of the whole test, it "takes its meaning from the context. Nothing is to happen to the child, and this was God's intention from the beginning. This half-verse makes clear and confirms that God never intended this cruel fate to befall the child." Westermann, Genesis 12-36, 361.

218 The deitic clause uses the particle "for, that" ( $k i)$ two times: for $(k i)$ now I know that $(k i)$. It is rare for narrators to pass overt moral judgment; they prefer to convey values through characters using the expression ki. Bar-Efrat, Narrative Art, 30. The function of $k i$ is causal here, encased in a special motivational clause following a strong prohibition heightened by 2 and the subjunctive. Anneli Aejmelaeus, "Function and Interpretation of כin Biblical Hebrew," Journal of Biblical Literature 105, no. 2 (1986): 204, accessed March 9, 2018, http://dx.doi.org/10.2307/3260389. 
son, from Me." This dramatic "climax, consequence, and conclusion" 219 to the test

touches on the psychology, assessment, and relationship between Abraham and God.

Psychologically, God plumbs past the narrator's disclosure of Abraham's intent

("to kill his son") which seems to fulfill the imperative ("offer him up there as a

sacrifice"), all the way down to Abraham's motivational identity ("you, fearing-one of

God"). ${ }^{220}$ Evaluatively, Abraham's inner state of reverence was exteriorized in objective

visible obedience ${ }^{221}$ which was internalized as present divine knowledge (now, I know). ${ }^{222}$

Hence God has not been a detached proctor in the test of the Aqedah but was profoundly

affected by Abraham's responses. Relationally, God's effusive commendations suggest

increased bonding between Abraham and God for relinquishing his son to God. ${ }^{223}$ But one

219 Trible, "Genesis 22," 178. The narrative drama builds up to this point, then is suddenly released. "The narrative reaches its peak when Abraham puts out his hand and takes the knife to slay his son. The turning point comes at the very moment that the tension reaches its height: an angel of the Lord calls to Abraham from heaven, and at the very last moment the terrible deed is prevented." Bar-Efrat, Narrative Art, 122.

${ }^{220}$ Distinction between Abraham's intent and motive demonstrates a sophisticated understanding of what lies behind actions. This distinction is critical for criminal culpability in American law. For the difference between intent (plan to carry out an act) and motive (the reason behind the intention) in law, see Justices Alito and Thomas' dissent discussion in Rosemond v. United States, 12-895 (SCOTUS 2014). God had also clarified this distinction in a dream to Abimelech: judging his motive as pure but his intent toward Sarah as sinful (Gen 20).

221 "In the Tanakh, the fear of God denotes an active obedience to the divine will." Fear of God was not understood to be limited to a private psychological state of mind. The Jewish Study Bible: Jewish Publication Society Tanakh Translation, eds. Adele Berlin and Marc Zvi Brettler (Oxford, UK: Oxford University Press, 2004), 46.

222 In the world of the narrative plot, divine experiential knowledge is self-revealed as dynamic with temporal characteristics.

${ }^{223}$ Abraham had already not withheld a son from God, namely Ishmael in Gen 21. Isaac is more significant, but Abraham has a proven habit of giving up family members to authority (Gen 12, 16, 20). God does the opposite, He withholds (חשך) Abimelech from sinning (Gen 20:6 "It was I who kept you from sinning against me.") and He withholds Abraham from killing Isaac, while simultaneously commending 
disquieting detail, easily overlooked, is God's truncated reference to Isaac in this evaluation as "your son, your only son." The last two emotive and covenantal designations (whom you love, Isaac) from the original test command have been dropped. Is this minor variation in repetition deliberate? In narrative analysis, it certainly is. In "an extremely sparse narrative, marked by formal symmetries, which exhibits a high degree of literal repetition, what you have to look for more frequently is the small but revealing differences in the seeming similarities, the nodes of emergent new meanings in the pattern of regular expectations created by explicit repetition," writes Alter. ${ }^{224}$ In particular, when verbal repetition happens within the same pericope (three sets of divine serial designations for Isaac), ${ }^{225}$ from the same character source (God) of the initial presentation, about the same verbal object (Isaac), Sternberg's Table of Repetition Types judges that variation as deliberate. ${ }^{226}$ Sternberg points out that the most valuable function of repetition resides "especially in the two areas about which the narrator is most reticent: the inner life of the agents and the ethical value of their acts. Repetition systematically

Abraham for "not withholding” (חשך) Isaac from Him.

${ }^{224}$ Alter, The Art of Biblical Narrative, 97. The Aqedah is an extremely sparse narrative marked by formal symmetries with literal repetitions.

${ }^{225}$ Repetition that echoes an earlier appearance in a different text is called an allusive fixture and that which occurs earlier in the same text is called an internal fixture. The closer together the repetitions are (internal fixture), the higher the probability that they function with a purpose. Sternberg, Poetics of Biblical Narrative, 390.

${ }^{226}$ According to Sternberg's Basic Guide to the Structure of Repetition Table, this pattern fits pattern no. 23 where the "motivation for retelling" with variation is to be considered purposeful or “deliberate." Sternberg, Poetics of Biblical Narrative, 434-435. 
illuminates those dark spots." 227 Thus in the Aqedah, deliberate variation in God's own words must be taken as a serious ethical evaluation. ${ }^{228}$ Abraham's test response seemingly fell short of God's ideal.

Freed by the angel's words, Abraham now "lifts his eyes and sees" for the second time in his test. ${ }^{229}$ In verse four, he lifted up his eyes and saw "the place from afar" that "God had said to him." This time, perhaps because no verbal indication was given, wonderful surprise ensues - he lifted up his eyes and saw and behold! He sees an animal in "the place"! A progressively clearer seeing is happening. ${ }^{230}$ Indeed, a photographic

${ }^{227}$ Sternberg, Poetics of Biblical Narrative, 438.

${ }^{228}$ This change is also buttressed by the narrator who employs the first and last designations together ("his son, Isaac" in vv 3, 6, 9) up to the moment Abraham reaches for the knife. From that moment in the story, "Isaac" is dropped from the usual pair of designations and only "his son" remains $(v 10,13)$. By the time Abraham starts down the mountain, the narrator drops any mention of his son altogether. The immediately ensuing lineage of Nahor features the plural term "sons" (v. 20) which backlights this lacuna at the end of the Aqedah.

${ }^{229}$ Surprisingly, though the leitmotif of the Aqedah is "seeing," Abraham is not depicted as visually comprehending God Himself. Abraham hears God. In the figure of speech for sight (he lifted up his eyes and saw), the concept of internal comprehension is primed by divine auditory instructions. Faith in God's word is what endows vision with potent inner spiritual meaning. What Abraham sees is the place and the ram that God provided.

230 "Abraham places his trust in God's seeing (v. 8) and that trust finally enables him to see the lamb that God has seen to. Seeing saves the son." Walter Brueggemann, "Genesis," in The New Interpreter's Bible, ed. Michael E. Lawrence (Nashville, TN: Abingdon Press, 1994), 495. Except that it is a ram, not a lamb. 
cluster of details is grasped immediately: the ram's location, ${ }^{231}$ its maturity, ${ }^{232}$ and the antecedent nature of the provision. ${ }^{233}$

In rapid succession the prescribed verbs of the test command (Take, go, offer) are fulfilled by Abraham on the animal: "Abraham went and took the ram and offered him up as a burnt offering instead of his son." The ram is offered up as an equivalent substitute for Isaac in the sacrifice, not as an afterthought or consolation filler. ${ }^{234}$ Yet no divine words explicitly mention the ram, no divine words gave Abraham permission to substitute it. It was Abraham's spiritual intuition that connected the angelic prohibition and the surprise ram together as two parts of a divinely provided solution for he

${ }^{231}$ I have presented in the grammatical-syntactical section some discussion on 'akhar vs'ekhad for whether the meaning is to be positional— "behind/after," chronological—"afterwards," or numerical— "one" or "another." In this section I would like to present some narrative arguments for translating it as "behind" (akhar). They are (1) Narrative Precedent: the previous identical phrase in v. 4 "he lifted up his eyes and saw" was followed by the object of sight with a spatial locator term immediately afterward, "the place from afar." Thus the pairing of object-spatial locator in ram/behind matches the previous place/from afar, (2) Positional Blind Spot: If Abraham and Isaac were scanning their horizon expectantly for the provision of an animal while building an altar, the highest possibility for missing the ram is because it is outside their field of vision - behind them and even more, hidden in a thicket, (3) Stylistic consistency of surprise: "behold!" (hinneh) adds surprise to the phrase "he lifted up his eyes and saw," "a ram!" adds surprise for not being a lamb but the prime candidate of sheep, "behind!" (akhar) adds surprise for overlooked location, "held by its horns in the thicket!" adds the chronologic element of surprise for God had already provided the solution before Isaac was bound in its [the ram's] stead.

${ }^{232}$ Abraham and Isaac expected God to provide a sheep or lamb (seh) in verses 7-8 (see the grammatical syntactical analysis of verse 7 on seh, page 90, note 69). Instead God provided a mature ram trapped by the symbol of its masculine maturity - its horns. Metaphorically, the ram is the father of the lamb.

${ }^{233}$ This is implied by its silent but trapped position in the bush. Initially, a grown ram would struggle to free itself with thrashing noises. But since the text suggests Abraham did not notice this animal until this exact moment, the implication is the ram had fallen silent by the time Abraham came to the altar site for its presence in the bush was only discerned by sight.

234 "God, the lamb, and the ram are involved in the same drama, as if they were identified with each other." Doukhan, Genesis, 286. 
proclaims ${ }^{235}$ the name of that place, "God will see/provide.” For Abraham, theocentric seeing/provision is the essence of "worship" (Gen 22:5), this is what makes a place sacred.

Though Abraham's conclusion could stand as the last word, the narrator deftly deploys a literary device that temporally transcends Abraham's conclusion. ${ }^{236}$ The narrator breaks through the temporal limits of the plot to transport the reader into the world of meaning in front of the text - a point chronologically after the Aqedah event, but before the reader's own time, into the narrator's world — with the phrase "as it is said to this [the narrator's] day." Abraham's hope-filled prophetic name for the place has been existentially interpreted by the narrator's contemporaries into a proverb of certainty, "On the mount of the Lord, there is sight." Vision in all directions (God is seen, man is seen, God's present and future provision is seen) is allowed by the masculine singular niphal form of ראה (to see).

\section{Conclusion}

And the Lord's messenger called out to Abraham once again from the heavens, and he said, "By my own Self I swear, declares the Lord, that because you have done this

\footnotetext{
235 Abraham usually talked ("he said") to God, servants, Isaac, and to the messenger of YHWH, but here for the first time in the narrative, Abraham called, as the messenger of YHWH had called to him. Did Abraham express proclamatory joy through verbal volume? Perhaps this is the moment referred to by Jesus in John 8:56, "Your father Abraham rejoiced that he was to see my day; he saw it and was glad."

${ }^{236}$ In modern parlance, suspending the performance convention of configured reality is called "breaking the fourth wall." In literature it is called "metalepsis" where the writer takes a hold of the "telling" of the story by changing levels. This happens when a character or narrator addresses the audience directly, refers to the plot or characters in the plot as such, thereby drawing attention to the dramatic or literary convention itself. Gerard Genette, Narrative Discourse: An Essay on Method (Ithaca, NY: Cornell University Press, 1972), 235. By sharing the proverb with the reader, the narrator validates communal hermeneutics that amended a faith-filled hope into certainty.
} 
thing and have not held back your son, your only one, I will greatly bless you and will greatly multiply your seed as the stars in the heavens and as the sand on the shore of the sea, and your seed shall take hold of its enemies' gate.

Since most of the epiphanies in the Abrahamic cycle end with a blessing (12:2;

$13: 16 ; 15: 5 ; 17: 2-6,16,20 ; 18: 18 ; 21: 13,18)$, the long standing historical-critical

categorization of verses $15-18$ as secondary additions based on their expansive linguistic

style has been challenged by several scholars. ${ }^{237}$ Narratively, this second angelic

proclamation includes and exceeds the scope and emotional range of the first evaluation, which fulfills the criteria for the literary device of build-up and climax. ${ }^{238}$ Against the backdrop of the ascending smoke from the recent ram sacrifice, the soaring oration of the Lord's blessings grants the final benediction.

God swears on His own name and underscores it by the prophetic clause declares the Lord. Together, they express absolute certainty about what is to follow. ${ }^{239}$ The covenant blessings are unleashed "because ${ }^{240}$ you did this thing and did not withhold your

${ }^{237}$ Coats, “Abraham's sacrifice of faith"; Van Seters, Abraham in History and Tradition; T. Desmond Alexander, "Genesis 22 and the Covenant of Circumcism," JSOT 8, no. 25 (1983): 17-22; Westermann, Genesis 12-36, 363; R. W. L. Moberly, "The Earliest Commentary on the Akedah," Vetus Testamentum 38, no. 3 (July 1988): 302-323; Wenham, Genesis 16-50, 102; Sternberg, Poetics of Biblical Narrative, 55; Hamilton, Genesis 18-50, 115.

${ }^{238}$ See the Gen 22:15 footnote about build-up and climax (BUC) in Grammatical Syntactical Analysis section, page 96, note 102 .

239 This first divine oath in the Patriarchal cycles becomes a foundational touchstone of faith to refer back to (Gen 24:7; 26:3; 50:24; Exod 13:5). Wenham, Genesis 16-50, 111. In Exod 32:13 Moses explicitly recalls this oath that "you swore by your own self" to hold God back from destroying the descendants of Isaac. The second phrase "declares the Lord" (which appears 364 times in the Hebrew Bible) underscores divine dependability.

${ }^{240}$ Gen 18:19 speaks of divine promise with contingent actualization when God muses, "For I have chosen him [Abraham], that he may command his children and his household after him to keep the way of the Lord by doing righteousness and justice, so that the Lord may bring to Abraham what he has promised him." The concept may be that even a promised gift requires obedient receptivity from the 
son, your only son." What constitutes this thing that Abraham accomplished? "This" suggests the preceding completed action of ram sacrifice as one linchpin, because Abraham's previous intent and physical attempt to sacrifice Isaac had been emphatically thwarted and prohibited by God and therefore not accomplished. Yet God commends Abraham's attitudinal willingness to not withold his precious progeny from God, this is the second linchpin. Together, the divine affirmations highlight what God endorses in Abraham's response to the test.

Suddenly divine exuberance is discharged ${ }^{241}$ through absolute infinitives followed by the finite form which magnify the verbs of blessings and multiplying. The three parts to the blessings are (1) emphatic certainty of blessing and multiplying of Abraham's seed reinforced by the double imagery of stars in the heavens and the sands on the seashore, (2) Abraham's seed will possess the gate of his enemies, ${ }^{242}$ and (3) all the nations will bless themselves through your seed. All three parts are rooted in past promises to Abraham, yet the focus of this renewal of the covenant has decidedly shifted downward

receiver in order to actualize its full effect. For instance, in Genesis 17 God had promised Abraham that Sarah would have a son in a year. However, it seems Sarah and Abraham weren't sexually active in the interim, for when God later visits Abraham's tent in Genesis chapter 18 and reiterates this same promise, Sarah laughs to herself, "After I am worn out and my lord is old, shall I have pleasure?" Postmenopausal vaginal dryness and age-related erectile dysfunction may have stymied their sexual life. Receptive obedience is required for full actualization of divine blessings.

${ }^{241}$ This juncture marks one of the differences between the approaches of narrative criticism and source criticism in the Aqedah. The synchronic approach of narrative analysis embraces the stylistic change in vocalization as rhetorically conveying exuberant joy while the diachronic approach had rejected and bracketed it out as an aberrant anachronistic anomaly precisely because of the poetic style.

${ }^{242}$ The Hebrew term for seed is a collective noun. Doukhan believes the singular masculine subject of the verbs in this section indicates the seed is referring to the promised Messiah, one singular individual who will possess the gates of his enemies and bless the nations. Doukhan, Genesis, 287. 
to the seed of Abraham. ${ }^{243}$ The seed of Abraham is what has been spared and will be blessed with the fullness of the covenant because "you obeyed my voice."

The final divine conclusion of the Aqedah, "you obeyed my voice," raises questions: (1) Abraham literally followed God's verbal directions, except in the manner of the ram sacrifice which was not commanded verbally. Is the ram sacrifice excluded from this affirmation of obeying God's voice or does God's voice include nonverbal divine communication? (2) The name of the place refers to God's actions, not Abraham's obedience. What then, was the purpose of the test command? (3) Though Abraham is roundly blessed for obeying God's voice, why do most believers not wish to be tested by God as Abraham was? Perhaps this test effectively reveals all believers' fear of God.

\section{Itinerary}

And Abraham returned to his lads, and they rose and went together to Beersheba, and Abraham dwelled in Beer-sheba.

The physical return of the participants to the original location signals a tidy ending to this pericope. But buried under the neatness is a nagging ambiguity on the whereabouts of Isaac. ${ }^{244}$ The Hebrew verb for return is in the masculine singular form and Abraham is its subject. Why is this? (1) Is Isaac so identified with Abraham (the two had walked as one) that after the ordeal they are referred to as a unified entity? ${ }^{245}$ Both the

\footnotetext{
243 The last image of Isaac in the Aqedah is his bound body on top of the altar wood. Only the phrase instead of his son indicates that Isaac has been removed from that position.

${ }^{244}$ Sarah is not mentioned at the beginning of the Aqedah, Isaac is not mentioned at the end. This may be to emphasize that the test's principal target was Abraham.

${ }^{245}$ Gen 12:6 also described the movement of Abraham's encampment as a composite entity through the masculine singular form of the verb. "Abram passed through the land to the place at Shechem,
} 
first and the last verbs in this verse (returned, dwelt) are in the masculine singular form, though Abraham's act of dwelling certainly includes his encampment. (2) Does the term "his [Abraham's] lads" refer only to the two servants left at the bottom of the mountain, or does it include Isaac? Abraham had previously referred to his son as a lad (v. 5) as did the messenger of YHWH (v. 12). (3) Is Isaac not with Abraham nor with the servants?246 It would not be surprising to sense the ambiguity in the ending as intentionally designed to evoke a yearning for closure, one that can only be found in the future Promised Seed of Abraham. Hovering over the last scene of Abraham and his companions trudging into the desert to get back to Beersheba lingers a faint echo of Isaac's wistful query, "But, where is the lamb?"

\section{Literary Structural Analysis}

Narratologists follow the arc of tension in the story, the buildup and relaxation of tension $^{247}$ suggested by Aristotle's plot scheme of beginning, middle and end. ${ }^{248}$ This

to the oak of Moreh."

${ }^{246}$ As for Isaac's whereabouts, one line of tradition believed he was burned, his ashes taken by God who then resurrected him: "Jewish weavers of tradition insisted that Isaac really gave his life on that sacred site, and the only son of Abraham was reduced to ashes. In infinite mercy God transported the ashes of Isaac to the Garden of Eden and revived him by heaven's dew." Crenshaw, Whirlpool of Torment, 27. Hamilton suggests the absence of Isaac from the end is to suggest that Abraham's intent to sacrifice Isaac is equivalent to returning Isaac to God through sacrifice, hence the (literarily) missing son. Hamilton, Genesis $18-50,117$.

${ }^{247}$ S. Bar-Efrat, "Some Observations on the Analysis of Structure in Biblical Narrative," Vetus Testamentum 30, no. 2 (1980): 165, accessed 14 March 2018, http://dx.doi.org/10.2307/1517521.

248 " A whole is what has a beginning and middle and end. A beginning is that which is not a necessary consequent of anything else but after which something else exists or happens as a natural result. An end on the contrary is that which is inevitably or, as a rule, the natural result of something else but from which nothing else follows; a middle follows something else and something follows from it. Well constructed plots must not therefore begin and end at random, but must embody the formulae we have 
suggests the main point of the story is the dramatic climax of vs. 11-12 where "at the very last moment the terrible deed is prevented. From here the line of the plot descends rapidly." ${ }^{249}$ Coats, however, sees Abraham's religious obedience as the element that unites the story, hence the test command of verses 1-2 necessitate the ringing reaffirmation of Abraham's obedience in the climactic verses 15-18: "because you did this thing. . . you obeyed my voice." ${ }^{250}$ Philosophers Kant and Kierkegaard are arrested by the human predicament and existential struggle in the ethical paradox of the test, the initial command to sacrifice Isaac and the anguish of the journey grabs their attention as the key to the enduring significance of the Aqedah. ${ }^{251}$ Thus, three possibilities exist for the main focus of the test; the narrative approach focuses on the seeming reversal of the threat to Isaac, the traditional religious approach focuses on the salvific or etiological themes in

stated." Aristotle, Poetics, (1450b27), accessed 9 December 2019, http://data.perseus.org/citations/urn:cts:greekLit:tlg0086.tlg034.perseus-eng1:1450b ction\%3D1450b.

${ }^{249}$ Bar-Efrat, Narrative Art in the Bible, 122. In the case of the Aqedah, this climax seems to be marked by the device of reversal (as with Jacob and Esau and Esther). Alter notices how this climax centers on the parental hand as in the preceding story of Ishmael's near death: "At the center of the story, Abraham's hand holds the knife, Hagar is enjoined to 'hold her hand' (the literal meaning in Hebrew) on the lad." Alter, Genesis, 106.

${ }^{250}$ Coats, “Abraham's Sacrifice of Faith,” 392-396. For Coats, the main theme is not about the riveting plight of the victim, the near sacrifice of Isaac, but the leitmotif of obedience-Abraham's faith filled obedience.

${ }^{251}$ Immanuel Kant, Religion within the Limits of Reason Alone, trans. H. H. Hudson and T. M. Greene (New York, NY: Harper, 1960), 175. See also Soren Kierkegaard's famous treatment of the Aqedah in his book, Fear and Trembling. 
the story's end, and the poetic, philosophical approach stresses the human condition or anguish at the beginning of the story. ${ }^{252}$

How can one arbitrate between these competing possibilities? "If the meaning of the Aqedah ultimately depends on the place where the accent is put, it is important to analyze the literary structure of the text in order to determine the point of accentuation and the orientation that is thereby brought to light.". ${ }^{253}$ The inherent literary structure is an ordering of the story's elements that exposes the priorities of the writer in setting down the tale. "It is the writer's vision or agenda that determines what is relevant." ${ }^{254}$

Shimon Bar-Efrat's article, "Some Observations on the Analysis of Structure in Biblical Narrative," suggests that four different levels of elements must be considered in structural analysis. They are "(1) the verbal level; (2) the level of narrative technique; (3) the level of the narrative world; (4) the level of the conceptual content." ${ }^{255}$ According to Bar-Efrat (1) the elements of the verbal world include metaphors, similes, unusual grammar or syntax, repetitions, (2) the elements of narrative technique refer to narrative explanations or comments, the difference between dialogues and narration, between

\footnotetext{
${ }^{252}$ Doukhan refers to the Talmud, medieval Rabbis, Church Fathers, Protestant Reformers and modern critics for the religious approach, and Immanuel Kant, Soren Kierkegaard, Pierre Emmanuel, and E. L. Fackenheim for the poetic or philosophical approach. Doukhan, "Center of the Aqedah," 17-18.

${ }^{253}$ Doukhan, "Center of the Aqedah," 18.

${ }^{254}$ Fokkelman goes on to explain, "the plot is an organization of the action in such a way as to result in an ingenious combination of the 'horizontal' and the 'vertical' arrangement." The linear axis of chronological succession of events make up the horizontal axis, the vertical axis is the vision of the writer that chooses only what is functional to his goal or plot. Fokkelman, Reading Biblical Narrative, 78.

${ }^{255}$ Bar-Efrat, Narrative Art in the Bible, 157.
} 
summary and scenic presentation, between narration and description, (3) narrative world elements consist of characters (identity, nature and function), events (temporal, causal relations and secondary plots) and (4) conceptual content refers to themes, issues or ideas in narrative units. Some of Bar-Efrat's elements have been addressed in the previous narrative analysis. For literary structural analysis, I will address additional elements of these four levels to discern the literary structure of the Aqedah that is text-based, coherent and comprehensive.

\section{Verbal and Narrative Technique Level}

By paying close attention to unique repeating phrases, verbal markers, silences and significant interactions between the main characters, Jacques Doukhan has convincingly filled out the dominant chiastic structure of the Aqedah narrative. The narrative chiastic structure is anchored by three dialogues, buttressed by the inclusio "wayyēlek k̂u šenehem yahdāw" (and they walked, the two of them, together), and incorporates the pattern of 6-5-6 $m r$ (he said) to zero in on $\mathrm{vv} 7-8$ as the center of the narrative. The following is an adaptation of Doukhan's outline of the narrative chiastic structure of the Aqedah. 
Gen 21:31 - 22:1, Prelude: Beersheba, theme of return, 'Now it came after these things'

A, vv. 1-2. Dialogue: God (Elōhîm) and Abraham

a. God's call

b. Abraham's response, hinnēnî

c. Order / Abraham

d. Order / the son, mountain to be designated

B, vv. 3-6. Abraham's walk

a. Departure

b. Wood on Isaac

c. Takes fire in his hand, and knife

d. 'The two of them went together'

C, vv. 7-8. Dialogue: Abraham and Isaac

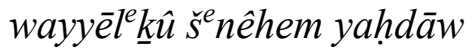
a. Silence
b. Question
c. Response, hinnennî
$\mathrm{b}^{1}$. Question
$a^{1}$. Silence

B1, vv. 9-10. Abraham's walk

wayyēek k̂̀ šenêhem yahdāw
d. 'The two of them went together'
a. Arrival
b. Isaac on wood
c. Takes knife in his hand

$\mathrm{A}_{1}$, vv. 11-19. Dialogue: God (Angel of YHWH) and Abraham
a. God's call
b. Abraham's response, hinnēnî
d. Order / the son, mountain designated
c. Blessing

Gen 22:19-20, Postlude: Beersheba, theme of return. 'Now it came after these things' 
The expansion of the central dialogue (C) of Abraham and Isaac shows the chiastic literary structure of $\boldsymbol{a} \boldsymbol{b} \boldsymbol{c} \boldsymbol{b}_{\boldsymbol{1}} \boldsymbol{a}_{\boldsymbol{1}}$ marking the exact center of the Aqedah.

a. Said Isaac to Abraham, his father-

b. And he said: father?

c. And he said: here I am, my son. [emphasis added]

$\boldsymbol{b}_{\boldsymbol{1}}$. And he said: here is the fire and the wood, but where is the lamb for offering?

a. And said Abraham: God will see to himself the lamb for offering my son.

The centralized meaning of the Aqedah narrative is not the faith-filled prophecy of Abraham, though that is a related theme, it is not the message of the angel of YHWH in verse 12, though that is the dramatic plot climax, it doesn't seem to be the ram sacrifice, though that is the provided solution, and it is not a religious etiology, though that is the lingering legacy. Doukhan avers, "The structure of the text suggests that the accent here is primarily on the human questions and silences at the center. More important than the response or solution would in this case be the question without response and the open silence of the human being experiencing the event. ${ }^{{ }^{256}}$ Questions and open silences do surround the pinpoint center of Abraham's tender reply to Isaac, which happens to be a verbal reassurance of authentic paternal responsiveness- - "Here I am, my son.”

In striking literary contrast to this central communication of paternal assurance, Phyllis Trible demonstrates how Abraham's four verb clusters convey underlying

${ }^{256}$ Doukhan, "Center of the Aqedah,” 28. 
tension. Irony lurks in the initial preparation for the journey (v. 3): "In the center, framed by six verbs that signal terrible obedience (rose, saddled, took; cut, arose, went), is the phrase 'Isaac his son.' The father's activity surrounds his son not to protect him in life but to prepare him for death." ${ }^{257}$ The fearful tension continues in the symmetrical transfer verbs of the accoutrements (v. 6): (took Abraham the wood...laid it upon Isaac...took in his hand the fire and the knife) "This time the objects, wood of the burnt offering and fire and knife surround 'Isaac his son.' . . The father embraces his son with potential destruction even as he protects him from immediate danger." ${ }_{258}$ The penultimate cluster of verbs setting up the altar points with threatening parallelism (v. 9): "Abraham alone is subject of six verbs, with Isaac appearing as object after each group of three. He receives center-stress and end-stress. ${ }^{259}$ Finally, the literary pattern of verbs regarding the ram support the meaning that Isaac is now safe (v. 13 and went Abraham, and took the ram, and sacrificed it for a burnt offering, instead of his son), "Strikingly, unlike the

\footnotetext{
${ }^{257}$ Trible, "Genesis 22," 174.

${ }^{258}$ Trible, “Genesis 22,” 175.

259 Trible, “Genesis 22," 177.
} 
syntactical patterns of previous sentences, the son stands here outside the action of the father." ${ }^{\prime 60}$ In a literary sense then, as well as in actuality, Isaac is released by Abraham.

\section{Narrative World Level}

It is clear to any reader of the Aqedah that on the narrative world level of characters and events, Abraham the father, Isaac the son, and God are the three main acting characters of the Aqedah. But the ram cannot be ignored without dramatically affecting the plot and religious implications. Thus, four characters are essential to the meaning and the stress of their contributions to the plot in relation to the chiastic structure is outlined below.

1. Abraham performs almost all the action verbs in the story and has a total of five speaking parts: three are dialogues (to God, to Isaac, to God) that anchor the ends (A and $A_{1}$ ) and center $(C)$ of the chiastic structure, two are utterances to outsiders: directions to his two servants (v. 5) and naming a place for progeny (v.14). His verbal and active contributions are captured in the general outline of Doukhan's chiastic structure.

2. Isaac is a passive character in this story except for one verbal exchange with his father Abraham (C). ${ }^{261}$ This human dialogue, which reveals their relationship, is

${ }^{260}$ Trible, “Genesis 22,” 180.

${ }^{261}$ This also happens to be the only recorded dialogue between Abraham and Isaac in the whole Bible. 
the center of the chiastic structure. His physical danger is reversed and resolved by the third dialogue $\left(A_{1}\right)$ in the chiasm.

3. God as a character performs three verbal utterances (dialogue, dialogue, monologue) which initiate, correct and conclude the test with evaluation. His speech of conclusion (c. Blessing vv 15-18) is the most emotive, complex and prolonged of the three. However, in the narrative chiastic structure this last utterance, sworn on his own name and referred to by subsequent generations, ${ }^{262}$ is subsumed as a subsection (c) of the last section $\left(\mathrm{A}_{1}\right)$ and the divine providence of the ram is hidden in the chiastic structure.

4. The ram is another a passive character, fulfilling a symbolic role as a proxy for God, then subsequently for Isaac as a substitutionary sacrifice. It fulfills Abraham's prophecy of a sheep from the center of the chiastic structure, and Abraham discharges the three imperatives of the test command on it. It saves

${ }^{262}$ Exod 32:13, Heb 6:13. 
Isaac by taking his place. However, the ram solution to the test is not given any prominence in the chiastic structure.

In summary, Abraham and Isaac's contributions to the story are nicely captured by the literary chiastic structure, while the contributions of God and the ram are inadequately featured.

\section{Conceptual Content Level}

The Aqedah's self-framing for the narrative is as a divine test (v. 1). Thus, to be faithful to the text, the conceptual content level of literary structure for the Aqedah would be expected to integrate paradigms of both narrative and test in some form. At a minimum, a literary structure for a test might demonstrate how the final solution relates (since we can only reason a posteriori-after the event) to the original test command. ${ }^{263} \mathrm{At}$ maximum, the literary test structure may unpack the test design, provide some evaluative hint on Abraham's performance, and indicate relevant preparation for this test. Arguably, the search for literary structure is a search for the inceptive vision of the writer. If the vision of the writer happens to exceed our expectations, the literary structure may too.

The existing literary chiasm of the Aqedah can be visualized as having a central dialogue as the middle peak (vv 7-8), anchored on either side by two other dialogues as angles (vv 1-2;11-12). The two sides of this triangle ${ }^{264}$ feature Abraham's walk up the

\footnotetext{
${ }^{263}$ In a sense there is a hermeneutical circle in the text that must go forward chronologically from the test command to the final divine evaluation to grasp what happened but then, must circle backward in retrospective reflection through the same recorded events to the original directive to understand what the test is about.

${ }^{264}$ The chiastic structure is an upside down "V" without a base. But for the purposes of integrating the chiastic structure with further refinement of it and to simplify communication to non-English readers,
} 
mountain (vv 3-6) and the preparations at the altar site (vv 9-10). Trailing from the right corner dialogue (vv 11-12) is the rest of the narrative comprised of a long list of verses (vv. 13-19), looking much like a tail. See figure 3.5 below.

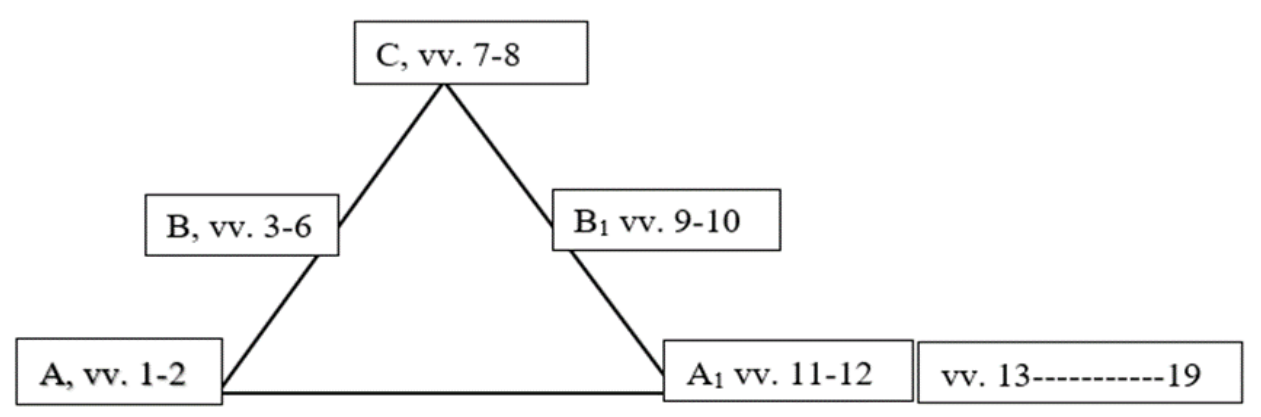

Figure 3.5 Chiastic structure of Aqedah

The "tail" or string of verses (vv. 13-19) shares phrases, key terms and concepts with the previous parts of the chiastic narrative structure. The first verse, verse 13, is the test solution of the ram and shares a figure of speech and three key verbs with B and A in that order.

v. 13a "And Abraham lifted up his eyes and looked—a ram, behind."

B, v. 3 ". . Abraham lifted up his eyes and saw the place, from afar."

v. 13b "Abraham went ... took... offered it [ram] up as a burnt offering"

A, v. 2 "Take...go ... offer him [Isaac] there as a burnt offering"

the mathematical triangle has been chosen for my schema. 
The second verse, verse 14, matches key terms and key phrases with $\mathrm{B}_{1}$ and $\mathrm{C}$ in that order.

v. 14a "So Abraham called the name of that place, 'The Lord will provide' $\mathrm{B}_{1}$, v. 9 "came to the place" C, v. 8 "God will provide" v. 14b "....... On the Mount of YHWH------------It will be provided"

The third verse, verse 15 is almost identical to $\mathrm{A}_{1}$.

v. 15 "And the angel of the Lord called to Abraham a second time from heaven" $\mathrm{A}_{1}, \mathrm{v} .12$ "But the angel of the Lord called to him from heaven ..."

The $16^{\text {th }}$ verse does not find a match within the verses of the Aqedah. Yet, it places the identity of God as the foundation for the oath of the covenant. If the connections of vv 13-15 to the chiastic structure presents a pattern to follow (side/angle [B-A]; side/angle $\left[\mathrm{B}_{1-\mathrm{C}} \mathrm{C}\right]$; angle $\left[\mathrm{A}_{1]}\right]$, v. 16ab would first match a side then an angle. It does! The first part (16a) can be envisioned as designating the bottom side of the triangle with the second part (16b) corresponding to angle A with "this thing."

v. 16 ab "By Myself I have sworn, declares the Lord ... you have done this thing (base/bottom side of chiastic triangle) A, v. 1 "after these things"

Since vv.13-16ab connect to the corners and sides of the chiastic structure in a sequential clockwise fashion, this line of verses can now be seen as a smaller clockwise circle inside the chiasm, corresponding to it. 


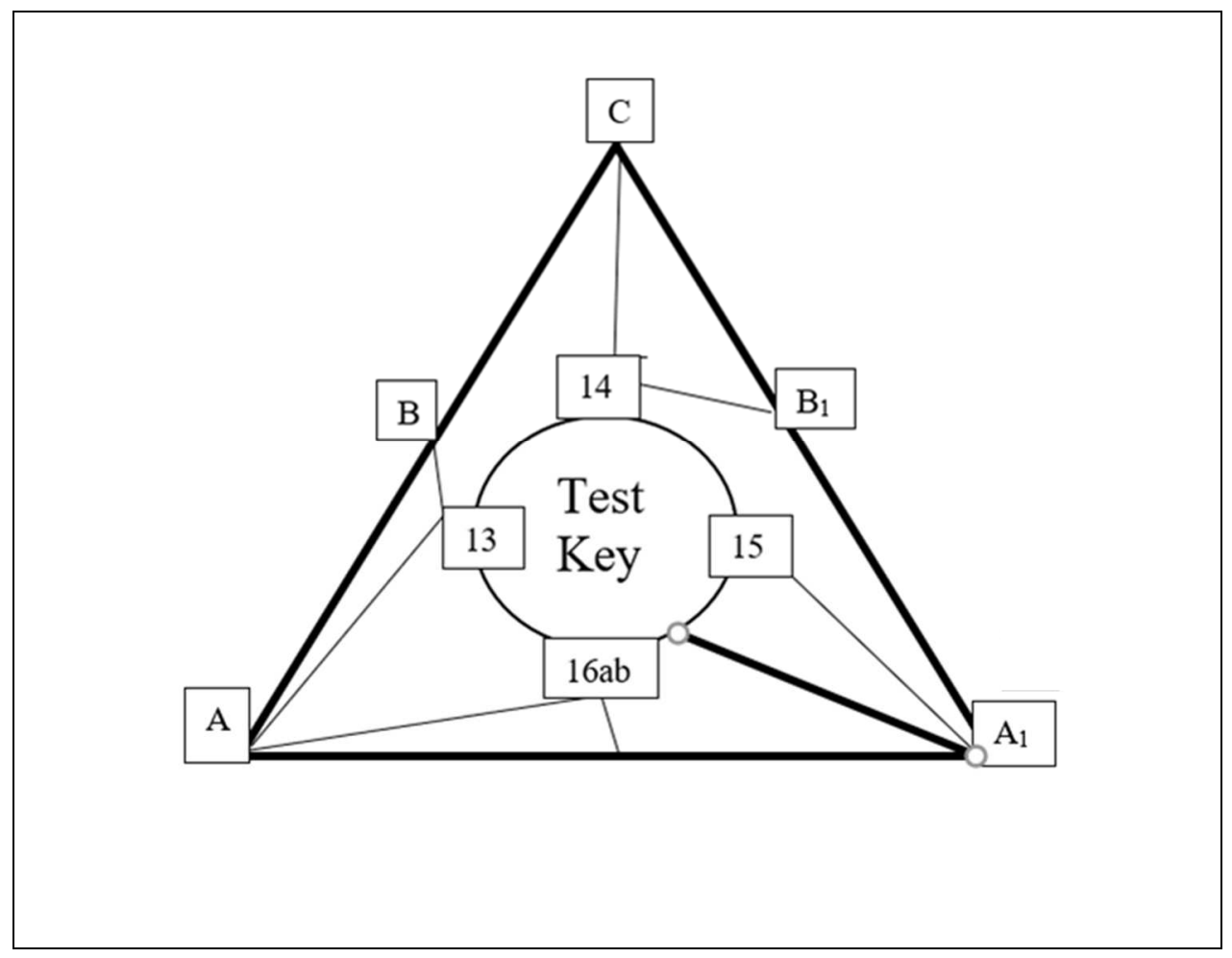

Figure 3.6 Aqedah Key. The phrases of verses $13-16 \mathrm{~b}$ are verbally linked to the chiasmus and illuminate the religious legacy of the test.

That is, the outer shape is the triangular chiasm of the narrative (vv 1-12). The inner circle represents vv. 13-16ab in relation to the chiastic structure. Conceptually, vv. 13-16b offer the final meaning, the lasting religious legacy of the chiastic components: the substitute ram that represents God, the sacred mount of YHWH and the grounding of 
the covenant on YHWH. This suggests that the circle of vv. 13-16ab, which constitutes the inner circle of this chiastic model functions as a test answer key ${ }^{265}$

What then is the function of the blessings in $16 \mathrm{c}-18$ ? They do not show direct verbal links to the story of the Aqedah itself, but verbal and conceptual connections to Abraham's previous revelations ${ }^{266}$ suggest a possible answer. Some of the previous covenant promises to Abraham are re-established here.

What has not been recognized until now is how comprehensive and deliberate these seem to be. Verses $16 \mathrm{c}-18$ correlate with the seven revelations of Abraham in words, phrases and concepts in an orderly manner. They line up with Abraham's prior

${ }^{265}$ A test key refers to a set of correct answers that explain or open the meaning of the test.

${ }^{266}$ Martin Buber outlines Abraham's seven revelations. He writes, “The seven revelations are seven stations on the way of a man from the beginning of the mutual relations between this man and God until its completion." Buber, On the Bible, 37. Buber does not include God's speech on Ishmael's banishment because it does not directly deal with the covenant to Isaac. In Buber's list the Aqedah is the seventh revelation. I choose to include Ishmael's banishment as the seventh revelation because it remains part of Abraham's training before the Aqedah test, a dry run if you will, of entrusting a son, a uniquely loved son to God. 
divine revelations in striking retrograde sequence. Each verse is followed by its

corresponding numbered revelation.

v. 16c "you did not withhold your son, your only"267 son"268

$7^{\text {th }}$ Revelation: Gen 21 "And the thing was very displeasing to Abraham

on account of his son ... putting on her [Hagar] shoulder the child

[Ishmael] and sent her away"

v. 17 "I will surely bless you and I will surely multiply your offspring"269

$5^{\text {th }}$ Revelation: Gen 17 “multiply" $\mathrm{x} 3$, "bless" $\mathrm{x} 3$.

"as the stars of heaven" 270

$4^{\text {th }}$ Revelation: Gen 15:5 "Look toward the heavens and number the stars .

.. so shall your offspring be."

"as sands of the seashore" 271

267 "It is interesting, however, that even $y \bar{a} h \hat{\imath} d$ was occasionally rendered into Greek with words indicating love. Thus, when God commands Abraham, "Take your son, your only son (yĕhîděkā), whom you love" (Gen 22:2), the Septuagint, the ancient Jewish translation of the Torah into Greek, employs the awkward locution "your beloved son, whom you love" (ton huion sou ton agapèton hon ègapēsas)." Levinson cites Judg 11:34, Amos 8:10, and Jer 6:26 as other examples of such translations. He reasons, "It is conceivable that some of these translations reflect a confusion of $y \bar{a} h \hat{\imath} d$ and $y \bar{a} d \hat{\imath} d$ in the underlying text, but, on the whole, it seems more likely that they testify to the tradition that understands yāhîn as a term for the beloved one, and, in the case of Abraham and Jephthah, for the beloved offspring whom the devout father is obliged to sacrifice and immolate. When, in the synoptic gospels, a heavenly voice declares, just after Jesus' baptism, "You are my beloved son, (huios mou ho agapétos); with you I am well pleased" (Mark 1:11 and parallels), a reference to that other beloved son, Isaac is surely to be understood." Levenson, Death and Resurrection, 30.

268 This twice repeated phrase "You did not withhold your son, your only son" refers to Abraham's choice not to hold back either of his two sons from God. The banishment of Ishmael may have been a "dry run" or pre-test experience for the Aqedah, thus the phrase can refer to two different events because they demonstrate the same virtue of Abraham's parenting style that raises children to look to God for everything. God as the consummate Tester had trained Abraham to succeed through a trust-building exercise with Ishmael before having him face the more difficult test with Isaac.

269 The terms for multiply and bless are in the Hebrew absolute infinitive form for extreme emphasis, this corresponds to the maximum three times repetition of these terms in Gen 17. "That Abraham's descendants would be extremely numerous (17:2; cf. 16:10)" Wenham, Genesis 16-50, 112. The promises of Genesis 17 include multiply three times $(17: 2,6,20)$ and bless three times $(17: 16$ twice, 20), including Ishmael as his descendant.

270 "Indeed, as countless as the stars (15:5)." Wenham, Genesis 16-50, 112.

271 The evoking of previous revelations does not exclude other overlapping relationships such as the stars and sand as a merism here and in Jeremiah 33:22, "As the host of heaven cannot be numbered and the sands of the sea cannot be measured, so I will multiply the offspring of David my servant, and the Levitical priests who minister to me." That the dust of the earth and sands of the sea were employed as equivalent phrases is given support in the story of Jacob, who was promised by God that his descendants 
$3^{\text {rd }}$ Revelation: Gen13:16 "I will make your offspring as the dust of the earth"

"your offspring shall possess the gates of his enemies" 272

$2^{\text {nd }}$ Revelation: Gen 12:7 "To your offspring I will give this land."

v. 18a "and in your offspring shall all the nations of the earth bless themselves" 273

$1^{\text {st }}$ Revelation: Gen 12:3 "In you all the families of the earth will be blessed."

v. 18b "because you have obeyed my voice."

Summary Judgment: Divine epitaph of Abraham to Isaac in Gen 26:5

"Because Abraham obeyed me and kept my charge, my commandments, my statutes and my laws."

These linguistic correlations and the sequential order of their allusions suggest the

final cluster of divine covenant blessings is more than a random burst of divine

exuberance. In fact, it looks very much like a systematic orderly assessment of

Abraham's test response in retrograde fashion that ends with a summary judgment. Six of the seven previous covenant revelations are indicated by this list.

The demarcated absence of one revelation speaks volumes. One of the most puzzling aspects of Abraham's behavior in the Aqedah for many scholars is the lack of moral protest from Abraham to God's command to sacrifice his son. The moral courage that Abraham showed in the $6^{\text {th }}$ Revelation (Genesis 18) when he negotiated with God based on divine justice and extended mercy is not displayed in the Aqedah. The list of

would be like the dust of the earth (Gen 28:14) but he later claims that God had promised that his descendants would be like the sands of the sea (Gen 32:12) without being rebuked. Finally, as one of my professors, Dr. John Reeves pointed out, the land of Israel geographically included sandy wilderness and desert regions where dust and sand were synonymous metaphors for ground material.

\footnotetext{
${ }^{272}$ Possessing the gates of your enemies is "a more realistic formulation of the promise of the land than earlier promises." Wenham, Genesis 16-50, 112.

${ }^{273}$ Wenham, Genesis 16-50, 112.
} 
rewarded divine blessings likewise has no linguistic connections to Abraham's $6^{\text {th }}$ Revelation (Gen 18). This matching omission in Abraham's test response and in God's final covenant blessings in the test supports the hypothesis that the divine blessings of vv. 15-18 indicate which covenant lessons Abraham actualized in the test, for they are prefaced by "because you have done this thing." Thus, no one needs to "unbind" the Aqedah, it unbinds itself!274 The schematic diagram of these blessings linked to the covenant revelations (see Fig. 3.7 below) metaphorically corresponds to the shape of a key blade (the working long arm of a physical key that inserts into a lock). this divine test.

${ }^{274}$ The word "unbind" has been used rhetorically to refer to explaining or unraveling the puzzle of 


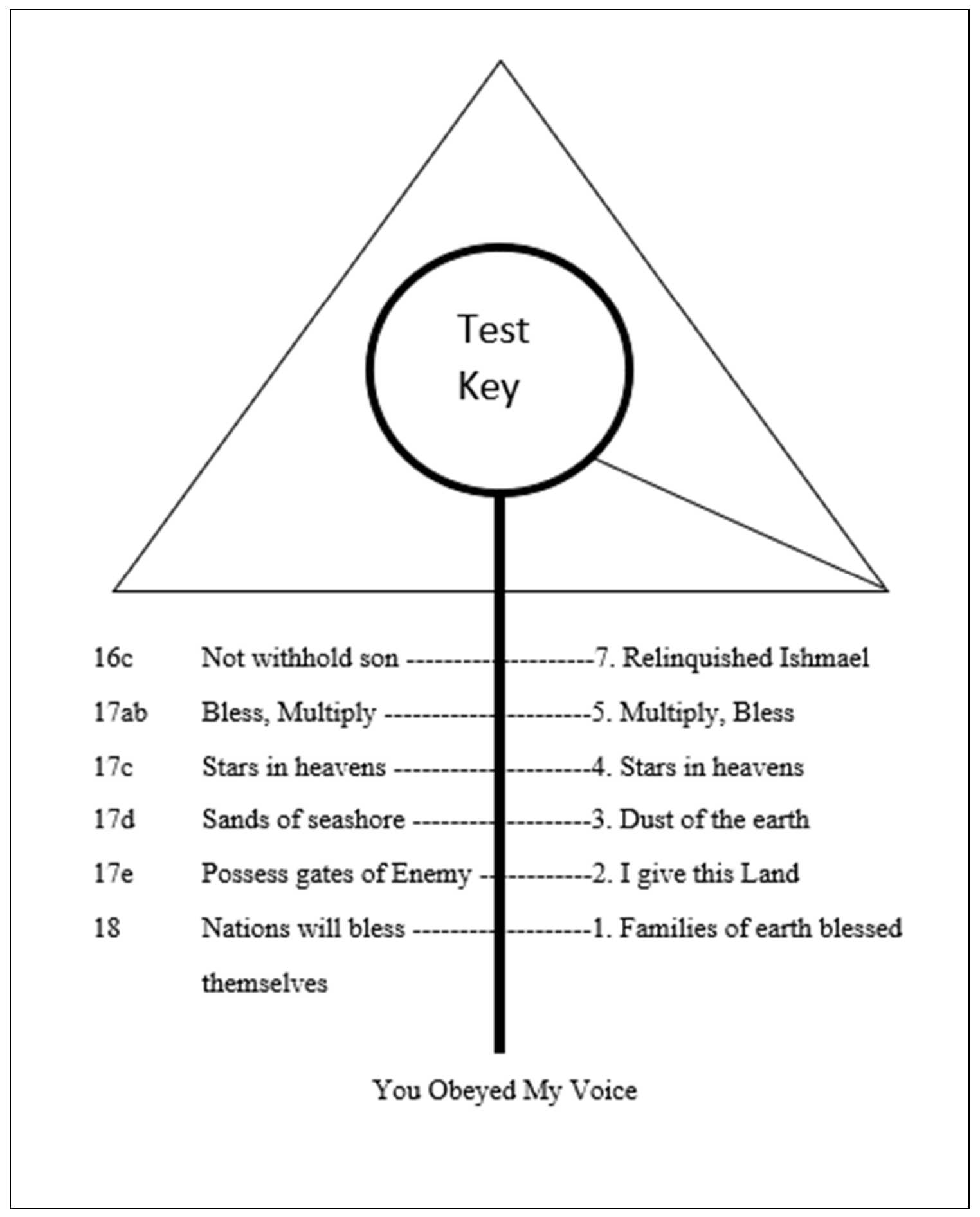

Figure 3.7 Aqedah Key List. The list of blessings compared to Abraham's seven prior revelations. 
To summarize, the Aqedah key list is the divine interpretation (v. 16a "By my own self I swear") of Abraham's test response (v. 16b "because of what you have done") that evokes the covenant revelations as a divine test norm, implying the Aqedah was a comprehensive test of all that Abraham had learned since the beginning of his journey from Haran. If this hypothesis for the literary structure of the Aqedah is correct, the Aqedah is more complex and comprehensive than previously assumed. It is now seen to be a test that contains a test command, execution, mid-test correction, substitutionary fulfillment, answer key and assessment through the re-establishment of covenant promises.

The key list suggests that the Aqedah may not be a test requiring Abraham to be willing to abdicate his covenant experience by killing Isaac, but one that requires Abraham to fulfill and enact his role as a divinely educated and trained covenant father. The micro-hermeneutical analysis has revealed the Aqedah contains the literary structure of a brilliantly designed narrative test, complete with its own hidden answer key. Finally, Gen 22:19-20 ends with a Postlude that matches the Prelude of Gen 21:34-22:1. Abraham started in Beersheba and ends in Beersheba; the test of Abraham started "after these things" and ends with "after these things.."275

\section{Conclusion}

This chapter started with a proposal to adapt the model of the hermeneutical spiral for theology by incorporating several key concepts: (1) the role of Scripture as the central

\footnotetext{
${ }^{275}$ Doukhan, "The Center of the Aqedah," 26.
} 
long axis of the hermeneutical spiral, (2) delineation of loops into micro-meso-macro hermeneutical levels, and (3) worlds of meaning (in, behind, in front of, above and below the text) of the spiral ramp. The model additionally incorporated the theological principles of Sola, Tota, and Prima Scriptura in the hermeneutical model.

Testing of this model by application to the Aqedah at the micro-hermeneutical level (biblical/textual principles of interpretation) was done through grammaticalsyntactical, narrative, and literary structural analysis. This micro-hermeneutical round of analysis supported many of the major findings of commentaries, it also revealed some areas that had been given less attention. In particular, the last divine speech in the Aqedah seems to hold potential for evaluating Abraham's performance in the test, even suggesting the revelations of the covenant were to be embodied in Abraham's response to the test, not abdicated. The meso-hermeneutical analysis of the next chapter will delve into the underlying logic, significance and theological meaning of these microhermeneutical findings.

The drawback of the Axial Model on the micro-hermeneutical level is that a casual reader will not wish to follow multiple analytic rounds of the whole pericope at one hermeneutical level. For them, one round is enough. This model doesn't dictate how thorough the analysis must be on any level, only of the need to respect the whole pericope as the norming axis for analyzing the biblical narratives, to systematically process the text by the literary structure and indications given by the text itself, to persist 
in studying the text through all three levels and to recognize the worlds of meaning as necessary for deeper understanding.

The main difference between the Axial Model of hermeneutics and what is usually done in interpretation is that the horizontal discipline of analyzing the complete pericope (Gen 22:1-19) multiple times through textual tools allows the whole text to norm the process and offset the interpreter's biases to some extent. The text is given a chance to speak through its own grammatical-rhetorical voice, to allocate significance to its own parts, and to allow its own literary structure to surface. If a vertical approach (sequential analysis of single verses utilizing multiple hermeneutical levels) is used, some of these textual insights might be overlooked by the interpreter's filtering dogma or rashly tethered to favorite theological ideologies. Once the micro-hermeneutical structure, drama and details of the text have been unearthed as sensitively and as fairly as possible, the meso-hermeneutical level organizes this data into a meaningful theology using the canonical context for guided framing and testing. 


\section{CHAPTER 4}

\section{A MESO-HERMENEUTIC FOR THE AQEDAH}

\section{Introduction}

Søren Kierkegaard's analysis of the Aqedah, Fear and Trembling, begins with four psychological scenarios ${ }^{1}$ that sets up the reader to appreciate Kierkegaard's inner depiction of Abraham as the paradoxical Knight of Faith. Though I am interested in the opposite direction, a theocentric viewpoint, it may be useful to introduce the mesohermeneutic level of the Axial Model with four common rationales given in the Aqedah literature for why God tested Abraham. The analogy in italics are of a king testing his friend.

1. God tested Abraham with the command to sacrifice Isaac to see if Abraham loves Him more than he loves his son. ${ }^{2}$ A king tests whether his friend's affection is

${ }^{1}$ My summary of Kierkegaard's four "Attunement” options with weaning analogy are:

1. Abraham pretends he is an idolatrous murderer to shift Isaac's naïve trust from his father to God. A mother blackens breast to wean the child, yet "the mother-she is still the same."

2. Abraham obeys but he cannot forget God did this to him. Isaac lives, but "Abraham's eyes were darkened, and he saw joy no more." A mother conceals her breast to wean the child, but "then the child no longer has a mother."

3. Abraham chose duty to God over his paternal duty, then repents of this sin (of forgetting his duty to his son) without finding peace. A mother grieves with the child at weaning, for "she and the child are more and more to be separated."

4. Abraham obeys while trying to hide his clenched despair and shuddering, but Isaac sees it and loses faith. A mother should have stronger sustenance at hand when weaning "so that the child does not perish." Søren Kierkegaard, Fear and Trembling, 44-48.

2 Augustine says, "In a word, not to value above God what God gives us." Origen sees Abraham 
authentic by requiring him to return the king's most valuable gift.

2. God tested Abraham with the command to sacrifice Isaac to see if Abraham was God-fearing and would comply unconditionally and absolutely. ${ }^{3}$ A king tests his subject's submission through literal obedience by demanding the most difficult sacrifice possible.

3. God tested Abraham with the command to sacrifice Isaac to see Abraham's morality. ${ }^{4}$ A king tests his choice of a morally worthy friend by seeing how he handles an unmistakably unethical order.

4. God tested Abraham with the command to sacrifice Isaac to see Abraham's faith in His power of resurrection. ${ }^{5} A$ king tests the limits of his friend's faith in him, by

struggling between "affection and faith, love of God and love of the flesh." Carey Ellen Walsh, "Christian Theological Interpretations of God's Grace in the Binding of Isaac," Perichoresis 10 no. 1 (2012): 52-53. The "narrative will strain Abraham's faith and obedience to the uttermost in order to reveal his deepest emotional attachment." Wenham, Genesis 16-50, 113.

3 "He [Abraham] must therefore unequivocally prove his worthiness to be God's elect. The totally disinterested nature of his devotion to God must be established beyond all doubt. It is this that dictates the abnormality of the test, and it is this very abnormality that explains why God, not His angel, must present it, in contrast to the order to desist. It would not be adequate for Abraham to be asked to sacrifice himself, because he would surely do this in order to preserve his son, and he would still know that the divine promises would be honored. The sacrifice of his son is thus the decisive ultimate test that can be devised." Sarna, Genesis, 393.

${ }^{4}$ Bodoff reads Abraham as using strategic compliance, "He did not rush—-he stalled! He broke up the task that he was given into numerous tasks, or steps, and at each one he stopped, waiting to see whether 'the Boss' had reconsidered. .. . Given Abraham's moral purity, we may reasonably conclude that if, at the very end, God had not rescinded His command for Isaac's death, Abraham would have rejected the command, chosen the moral course of not committing murder, and saved his son - and then been forced to re-examine the prospects of his new religion, and the belief and faith on which it rested." Bodoff, The Unbinding of Isaac, 39. Omri Boehm sees God testing Abraham's morality, but in the original narrative (Gen 22:1-10,13,19) Abraham ethically sacrificed the ram instead of Isaac on his own initiative, thereby passing the test. Boehm notes that medieval interpreters such as Maimonides and his followers perceived two layers of meaning in the Aqedah, the external one of obedience "to maintain politico-religious stability" and the esoteric, concealed layer of disobedience - as Abraham's "true affirmation of faith." Boehm, The Binding of Isaac, 2, 13, 23.

${ }^{5}$ The writer of Hebrews 11:17-19 explains, "By faith Abraham, when he was tested, offered up Isaac, and he who had received the promises was in the act of offering up his only son, of whom it was said, 'Through Isaac shall your offspring be named.' He considered that God was able even to raise him from the dead, from which, figuratively speaking, he did receive him back." Many Christian theologians read this rationale into the Genesis narrative. Kierkegaard depicts Abraham's courage as paradoxical, "To renounce the whole of temporality ... then to grasp the whole of temporality on the strength of the absurd . .. that courage is the courage of faith. Through faith Abraham did not renounce his claim on Isaac, through 
setting him up to behave in a manner that necessitates hope in the impossible.

The interpretations based on these four themes of love, compliance, morality and resurrection will be the group referenced by the term "traditional interpretations" for this study. This chapter on the meso-hermeneutical level of the Axial Model focuses on theology and dogmatics. Because multiple subspecialties of theology ${ }^{6}$ exist, a choice must be made to choose one of them for analysis. This is not to ignore the richness of the Aqedah for historical research, theological development, typology, systematic truths, morality, ethics and praxis. Since the Axial Model is a continuous spiral model, other options can be pursued on future journeys. But to be very clear, for this present study through Genesis 22:1-19 my chosen theological task on the meso-hermeneutical level is text interpretation.

Charles Taylor defined interpretation as that which "aims to bring to light an underlying coherence or sense." But for an interpretation to be successful, it must articulate from the text an underlying logic and also demonstrate an intuitive fidelity to reality. ${ }^{8}$ This requires, as Schleiermacher saw, attending to the "origin of the text

his faith he received Isaac." Kierkegaard, Fear and Trembling, 77.

${ }^{6}$ Bernard Lonergan outlined eight functional specialties in the enterprise of theology, each requiring different methods: Research, Interpretation, History, Dialectics, Foundations, Doctrines, Systematics, Communications. Bernard Lonergan, Method in Theology (Toronto, CDN: University of Toronto Press, 1971), 169.

${ }^{7}$ Charles Taylor, "Interpretation and the Sciences of Man," The Review of Metaphysics 25, no. 1 (September 1971): 3. Already, macro-hermeneutical assumptions are being made - that an underlying coherence exists in a text and can be recognized by humans.

${ }^{8}$ In terms of persuasive power, these two aspects of internal coherence and external coherence are powerful and often trump raw research data. Daryl J. Bem, Andrea Allen, "On Predicting Some of the People Some of the Time: The Search for Cross-Sectional Consistencies in Behavior," Psychological 
(reaching 'behind' a text), the content ('within' the text), and its effects ('in front of' the text)." Previously in micro-hermeneutics, the world in the text was the focus, now, mesohermeneutics takes the world in the text and relates it to the worlds of meaning behind the text and in front of the text on the X-axis of the Axial Model. In concrete terms, the canon that precedes and follows the text provides a literary framing and norm that orients and tests the meaning of the text through the principle of Tota Scriptura. Extended further, the existential worlds of meaning of the biblical writer behind the text and the traditional history of text reception in front of the text also confront the reader-interpreter who brings their own personal worlds of meaning into the interpretive task. Integration of these objective, subjective, and cultural components is acknowledged in Charles Taylor's definition of meaning in which meaning is always (1) about something, (2) for someone, and conveys (3) a sense related to fields of other meanings. ${ }^{10}$

Since subjective and cultural elements are an inherent part of interpretive meaning, E. D. Hirsch is right to worry, "Is interpretation really a discipline, or is it just a playground for the jousting of opinions, fancies and private preferences, where the stake is not knowledge but the so-called higher humane values?"11 I believe correct interpretation is both a playground and discipline, first one then the other. ${ }^{12}$ Some have

Review 81, no. 6 (1974): 510.

\footnotetext{
${ }^{9}$ Schleiermacher cited by Thiselton in Hermeneutics, 160.

10 Taylor, "Interpretation and the Sciences of Man," 12.

${ }^{11}$ E. D. Hirsch, Jr., Validity in Interpretation (New Haven, CT: Yale University Press, 1967), 163.

${ }^{12}$ Hirsch supports this sequence, "But the fact that these two activities require and accompany one
} 
argued that hermeneutics is not a philosophy with methods but a movement similar to existentialism because its goal is meaning, ${ }^{13}$ however, I believe that meaningfulness can be assessed and compared. Sound interpretation may start with a creative appropriating process called the hermeneutical circle or hermeneutical method,,$^{14}$ but that can be distilled into a testable interpretive hypothesis which can be critiqued then for relevance.

This chapter will proceed through three sections. First, I will elucidate the role of the interpreter (for someone) in the Axial Model. Second, a concise overview of four phases for text interpretation ${ }^{15}$ will be given. Third, the Aqedah text (about something) will guide the application of interpretive methods to itself and the resulting interpretive hypothesis will be tested by the norm of the canon (a sense related to fields of other

another in the process of understanding should not lead us to confuse the whimsical lawlessness of guessing with the ultimately methodical character of testing. Both processes are necessary in interpretation, but only one of them is governed by logical principles. ... He [Schleiermacher] thus recognized implicitly the comparative nature of probability judgments, and though he rightly insisted that the divinatory and comparative functions go together, he failed to notice that one function is always prior to the other, that female intuition brings forth the ideas which the comparative male judgment then tests and either accepts or rejects." Hirsch, Validity in Interpretation, 204-205.

${ }^{13}$ Gary Shapiro and Alan Sica, Hermeneutics: Questions and Prospects (Amherst, MA: University of Massachusetts Press, 1984), 3-4.

${ }^{14}$ The hermeneutical circle or method is the acknowledgement that understanding requires a dialogical movement of inductive and deductive reasoning, from anticipation of the whole meaning (preunderstanding) to examining the detailed data, then back again to adjust the first impression and so on. David Klemm, "General Introduction," in Hermeneutical Inquiry: The Interpretation of Texts, Vol. 1 (Atlanta, GA: Scholars Press, 1986), 23-32. methodologies.

${ }^{15}$ Because it is a continuous spiral model, future rounds of meso-hermeneutics may employ other 
meaning) then critiqued for relevance. All of this requires an engaged self-aware

interpreter, whose role in the Axial Model deserves explanation.

\section{Interpreter in the Model}

In some hermeneutical models, the human subject is either missing, rendered as dot traveling along a line, or exists as an inert label in an otherwise dynamic diagram. ${ }^{16}$ This is the opposite of reality. The living human interpreter is the most dynamic, creative, and historically conditioned element who activates the process of interpretation, taking on the task of making meaning clear. ${ }^{17}$ If, as some models suggest, the interpreter adds little to the process except to apply the method, how can identical methodology applied to the same text by different competent interpreters generate a variety of interpretive meanings?

And yet, this is a common occurrence. To be sure, conflicting interpretations may

\footnotetext{
${ }^{16}$ Such models convey the impression of an objective process, unaffected by human subjectivity. This ignores what is human about humans - that they are undeniably historical organisms, laden with prejudice, bias, presuppositions both conscious and unconscious. Even bracketing, Husserl's method of consciously suspending presuppositions (e.g., time-space context) to minimize human bias - may paradoxically render it even more insidious and powerful precisely because it is unacknowledged and thus uncontrollable. Many hermeneutical models can be found in Grant Osborne's excellent work, The Hermeneutical Spiral, see pages 167, 203, 348, 351, 354, 386, 417-419.

${ }^{17}$ In some ways text interpretation is analogous to problem solving in the sciences. Michael Polanyi saw creativity for problem solving in mathematics resided in "the student's technical facility for transforming the given data in different ways and by the range of germane theorems with which he is acquainted." An intuition of logical relations is deemed necessary for "success will depend ultimately on his capacity for sensing the presence of yet unrevealed logical relations between the conditions of the problem, the theorems known to him and the unknown solution he is looking for." Michael Polanyi, "Problem Solving," British Journal for the Philosophy of Science 8, no. 30 (August 1957), 99.
} 
eventually require normative solutions, ${ }^{18}$ but it seems prematurely brutish to efface the vibrant humanity of the interpreter with static, atemporal hermeneutical models.

The Axial Model has already recognized the text as a historical entity bearing multiple worlds of meaning so it makes sense to recognize that the human reader is also a historical entity who comes to the text imbued with his or her personal worlds of meaning (see Fig. 4.1a below). ${ }^{19}$ It cannot be denied from our comparative study of Aqedah interpretations that Levenson and Fretheim bring different life experiences, canons (Jewish and Christian) and methods (historical-social and existential) to the text. These interpretive tools from their personal worlds of meaning influence and enrich their interpretations which must then be normed by the text for validity.

In the Axial Model the interpreter's personal worlds of meaning are depicted as anchored to a central core of identity. If the interpreter happens to be a believer, that

${ }^{18}$ Evaluation is necessary because "not all plausible interpretations are compatible . . . the fact that all interpretations are different warrants neither the sanguine belief that all plausible interpretations are helpful and compatible nor the hopeless proposition that all interpretations are personal, temporal, and incommensurable." Hirsch, Validity in Interpretation, 128-129.

${ }^{19}$ We find ourselves already existing in a world, within a certain situation, profoundly shaped by this involuntary condition. Heidegger referred to Dasein being the thrown of the throw that becomes aware of its being-in-the-world. Heidegger, Being and Time, 181-183fn. Gadamer also rejected the assumption of the radically autonomous self as a false delusion, "History does not belong to us, we belong to it." The traditions of history that form our perspectival vision create worlds of meaning "into which we move and that moves with us." Gadamer, Truth and Method, 288-289, 302, 315. Dissertationists like myself, find ourselves in a technological era marked by the "imperiled digital human condition" where the dissertating Dasein must grapple with the "tensions between memory loss (technological obsolescence) and the hauntings of everlasting data." Incredible technological advances are offset by the volume intimidation of overwhelming impersonal data. Amanda Lagerkvist, "Existential Media: Toward a Theorization of Digital Thrownness," New Media and Society 19, no. 1 (2017), 107. Today's Dasein discloses not one world but multiple "open, coherent, distinct contexts or worlds in which we perceive, feel, act, think." Hubert Dreyfus and Charles Spinosa, "Further Reflections on Heidegger, Technology and the Everyday," in Philosophical Romanticism, ed. Nikolas Kompridis (New York: Routledge, 2006), 265. 
anchoring core $^{20}$ is held together by Scripture as provisionally understood (see Fig. $4.1 \mathrm{~b}$ below). Scripture informs and stabilizes the ground, guardrails and feedback system for self-understanding, worldview, and philosophical presuppositions. Thus, appropriated Scripture affects core identity and pervades the attached personal worlds of meaning.

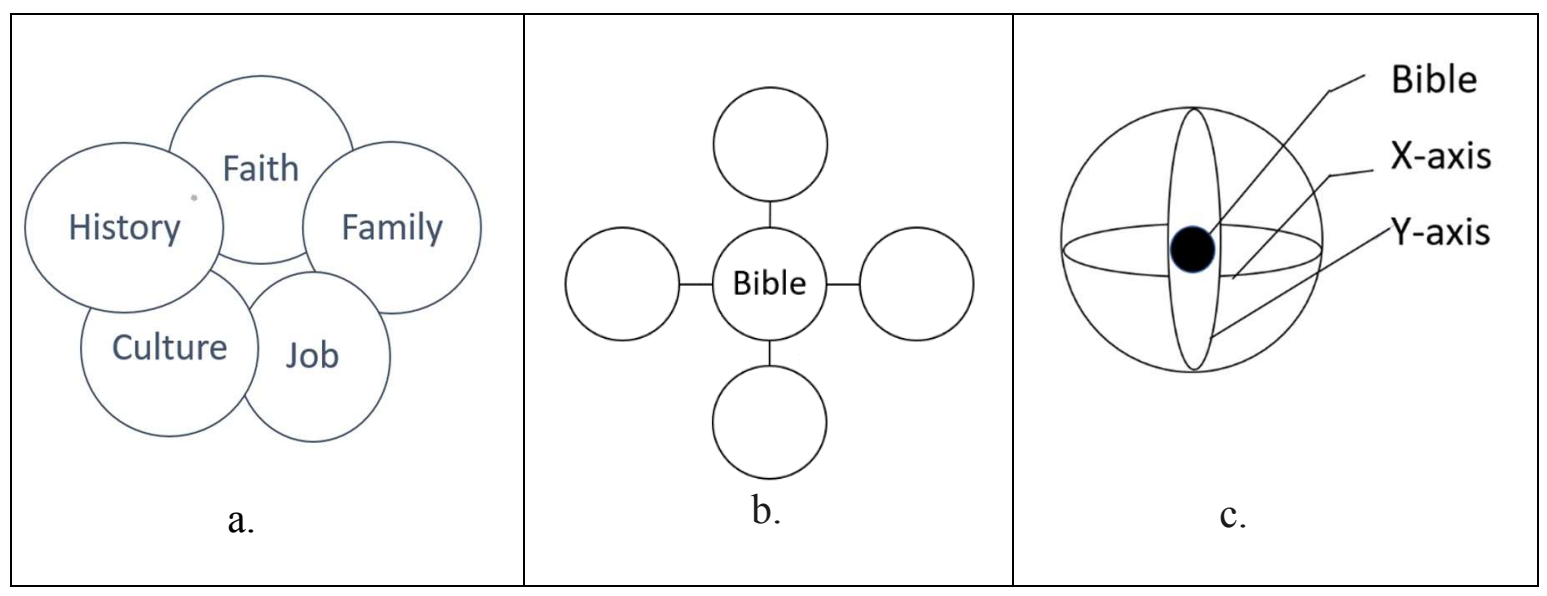

Fig. 4.1 Interpreter's Sphere. a. Personal Worlds of Meaning. b. Anchored to a biblically grounded core. c. Interpreter's Axes.

For pictoral simplicity, the personal worlds of meaning can be coalesced into two axes (Fig. 4.1c). The horizontal X-axis of the sphere refers to the worlds of meaning behind and the worlds of meaning in front of this moment of existence. They include

${ }^{20}$ If the interpreter is not a believer in God and the Bible as God's Word, then Scripture as provisionally understood becomes just one area of interest, a personal world of meaning among many other worlds of meaning. This means change in the meaning of Scripture will have localized effect on adjacent worlds of meaning, but not necessarily transform the core of the interpreter's sphere. Secular core identity can be wrapped by a cultural or family role, a career identity, or a loose patchwork of eclectic hopes and past experiences. 
personal narratives and future hopes. The vertical Y-axis represents the worlds of meaning above and below, personal presuppositions of ultimate reality about God and the cosmos. The temporal Z-axis of the sphere is a punctate core because the human lifespan is very brief relative to the long Z-axis of objective Scripture that has lasted thousands of years. The interpreter's core which represents the core self in the present moment, is where Scripture is provisionally understood or heard ${ }^{21}$ for understanding happens in the present. From the converted core, the Principle of Prima Scriptura is actualized by a dynamic wave of change that radiates from the core and transforms the tethered worlds of personal meaning. ${ }^{22}$

Understanding is a complex process that is produced by three kinds of spirals. In the first, the interpreter's sphere travels on the hermeneutical ramp in a spiral pattern with the interpreter repeatedly encountering the objective scriptural text (central long axis) then traversing the accessible biblical worlds of meaning (the ramp) in a looping spiral. ${ }^{23}$

${ }^{21}$ The original objective text and the human working copy of the text comprise the two anchoring poles of this model. The relative chronological duration of each is reflected as a line and a point, respectively. Correction of the dynamic internalized text of the interpreter is sparked by an unexpected or surprising discrepancy in making sense that necessitates a return and re-reading of the external objective text in order to "hear" it better and incorporate it more fully into one's life. Aspects or meanings of the Bible that are not appropriated would naturally have no bearing on the personal worlds of meaning.

${ }^{22}$ Prima Scriptura is actualized as a dynamic life-changing principle when the interpreter accepts the teaching of Scripture as the prime revelation by which all other theological sources must be judged. Thus, a newly grasped understanding of Scripture readjusts an interpretation of a past experience, reshapes the future vision and goals of the reader, opens a new vista on the character of God or elicits heartfelt repentance on an overlooked sin. This leads to new perceptions and action.

${ }^{23}$ A Bible commentary demonstrates this cognitive spiraling path in literary form. A verse (or an aspect of the verse) is presented, then followed by a discussion drawn from the worlds of meaning (archeology, anthropology, language, history, theology, etc.) relevant to the verse, this pattern is then repeated for each subsequent verse. Thus, "most commentaries that we call interpretations are concerned with significance as well as meaning." Hirsch, Validity in Interpretation, 136. 
This flat spiral circuit (see Fig. 4.2a below) on the ramp represents the chosen path of the hermeneutical method that relates the text (the whole) to its biblical worlds of meaning (the parts) through the words and syntactical formulations. The specific path is influenced by the theological task or goal of the interpreter. ${ }^{24}$

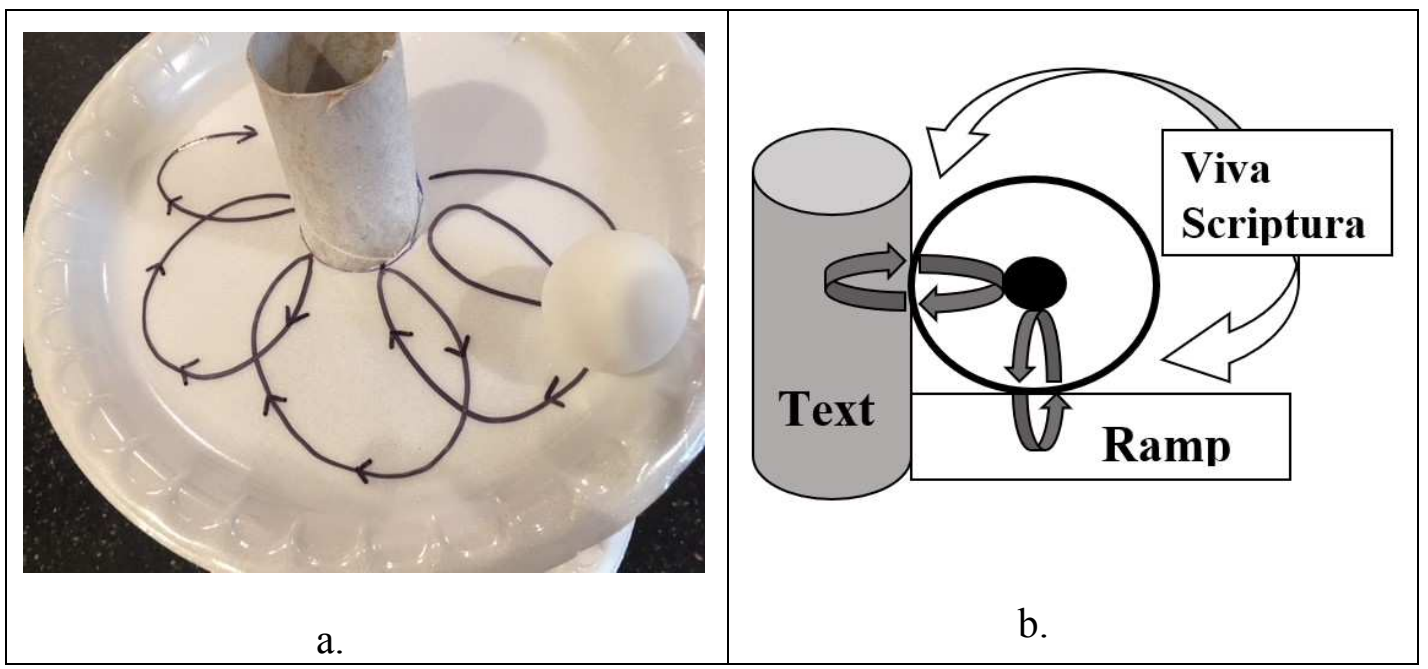

Fig. 4.2 Spiral circuit of interpreter (a) and Viva Scriptura (b).

The second kind of spiral that functions simultaneously with the first (see Fig. 4.2b) internally integrates the finished text puzzle as a personal conviction, melding the cognitive, emotive, and physical effects of personal understanding. This happens when the interpreter brings to the text their personal worlds of meaning as their horizon of

${ }^{24}$ Bernard Lonergan, Method in Theology, 169. For example, if the goal is textual research, the circuit would traverse from the objective text in its final form to ancient biblical worlds of meaning as indicated by its terms and syntax, which are comprised of materials (ancient documents, artifacts, and artworks) relevant for testing reliability, veracity, and historic value. 
understanding and asks questions of the text. The answers found in the text and by the study of the text with its worlds of meaning, norm, inform, and redirect the questions posed to it. The insights from this question and answer process are then incorporated, or fused with the interpreter's spherical horizon, enlarging the interpreter's personal horizon of understanding.

The third spiral of understanding is the broader projection and integration of the hermeneutical levels by the interpreter moving up or down the spiral ramps from level to level. This process is demonstrated in this study by the projection and integration of findings from chapter 3 (micro-hermeneutics) to chapter 4 (meso-hermeneutics), then absorbed into chapter 5 (macro-hermeneutics) of this study. The three-tiered hermeneutical process integrates the exegetical, theological and philosophical analysis of the Aqedah into a coherent whole as normed by the text.

All three spirals require contact between the sphere's surface and the spiral ramp of the Axial Model. Here is where the Principle of Viva Scriptura (Fig. 4.2b) acts. Though this may be a new term, the Principle of Viva Scriptura refers to the dynamic fusion of human and biblical horizons by the Holy Spirit who enables the understanding of God's Word to become a transformative power, a genuine conviction. ${ }^{25}$ When biblical understanding is internalized through Spirit-empowered appropriation into the interpreter's core, the personalized Principle of Prima Scriptura then permeates from the

\footnotetext{
${ }^{25}$ This marks the difference in the scope of understanding between the reader of the biblical text who gains only cognitive information and another reader who is profoundly converted by reading the same text. Life changing understanding that is facilitated and effected by God the Holy Spirit is the hermeneutical Principle of Viva Scriptura.
} 
interpreter's core outward to their tethered personal worlds of meaning. The result is a new perspective, a "new birth" conversion from biblical insight. The internalizing principle of Viva Scriptura with the suffusing power of Prima Scriptura is salvific and transformational. It all starts with the desire to authentically hear and incorporate God's Word.

\section{Phases of Interpretation}

It has been said to hear ancient texts as living works, "every age must reinterpret for itself the texts of the past." ${ }^{26}$ E. D. Hirsch ${ }^{27}$ differentiated meaning from interpretation when he said this proverb “doesn't mean the meaning changes, only that interpretation does." ${ }^{28}$ He later clarifies, "It is more descriptive to say that each age must re-criticize the works of the past in order to keep them alive and ourselves alive to them. As critics we

${ }^{26}$ Hirsch, Validity in Interpretation, 42.

${ }^{27}$ I have chosen Hirsch's methodology for this round of meso-hermeneutics because he retains a high respect for authorial intent and his phases of "understanding, interpretation, judgment, criticism," incorporate a self-critical method for testing any hypothesis. Hirsch, Validity in Interpretation, 133-144. Critique of Hirsch's methods and philosophy with further developments in hermeneutics can be found in American Literary Criticism since the 1930's by Vincent B. Leitch (New York, NY: Routledge, 2010), 162-169. I resonate with the literary camp of hypothetical intentionalists as opposed to actual intentionalists such as Hirsch. I acknowledge that interpretation is an earnest attempt to arrive at the "best possible hypothesis" about the author's intentions that "a suitably equipped reader" "can reasonably take him or her to mean" by examining the intentional direction of the text. See Types of Interpretation in the Aesthetic Disciplines, eds. Staffan Carlshamre, Anders Petterson (Ithaca, NY: Mc Gill University Press, 2003), 11.

${ }^{28}$ Hirsch, Validity in Interpretation, 42. 
should remind ourselves that we are not perceiving a new work or a new meaning, but a new significance of the work." ${ }^{29}$

Hirsch famously differentiated meaning as stable but significance as always open to change. "Meaning is that which is represented by the text; it is what the author meant by his use of a particular sign sequence; it is what the signs represent. Significance, on the other hand, names a relationship between that meaning and a person, or a conception, or a situation, or indeed anything imaginable." ${ }_{31}$ Meaning requires both understanding and interpretation, significance consists of judgment and criticism. The order does not imply that the latter phases are less important than the first ones, in fact, the potential

${ }^{29}$ Hirsch, Validity in Interpretation, 137 fn 5.

${ }^{30}$ Hirsch's method of philological hermeneutics partially incorporated "Gadamer's divinatory and historicist notion of 'application' into his interpretative theory of reconstruction" but he kept the original historical meaning of a text separate from the current relevance of a text. Hirsch's New Hermeneutic critics believed that "meanings must change over time, since history does, and, as it does so, human understanding changes." Vincent B. Leitch, American Literary Criticism, 168.

${ }^{31}$ Hirsch, Validity in Interpretation, 8. 
understanding in the first phase has no impact on reality if there is no relevance to it as examined in the last phase.

Hirsch's four sequential hermeneutical phases are:

1. Understanding - construction of meaning, ${ }^{32}$

2. Interpretation - explanation of meaning (adapted to Interpretive Hypothesis), ${ }^{33}$

3. Judgment - validating a relation of meaning to something else, ${ }^{34}$

4. Criticism - valuation of that validated meaning. ${ }^{35}$

For the rest of this chapter these four phases will guide the interpretation of the Aqedah on the meso-hermeneutical level of the spiral model. Each one of the four phases

32 "Understanding is construction of meaning." Hirsch, Validity in Interpretation, 136.

33 "So interpretation is an explanation of meaning." Hirsch, Validity in Interpretation, 136. Because the term interpretation has been used loosely to cover many aspects of hermeneutics, I will adapt Hirsch's term interpretation to interpretive hypothesis. Especially for a narrative, a succinct interpretive hypothesis of it is the only way to render a story accessible for testing by a norm.

34 "The act of judging is the construing of this relationship, whether it be that between a meaning and criteria of value or between a meaning and anything else imaginable." Hirsch, Validity in Interpretation, 143.

35 "Criticism is not identical with significance, but rather refers to it, talks about it, describes it ... perhaps the most important function of criticism as distinguished from interpretation is to show that a work is valuable or valueless in some respect.” Hirsch, Validity in Interpretation, 144. 
will initially explain its particular theory and method then demonstrate its application.

Wherever possible, the biblical text will direct the application of the method to itself.

\author{
Understanding
}

\title{
Theory and Method of Understanding
}

Hirsch believed there was no methodology for constructing a meaning of the text. ${ }^{36}$ Yet he described the first phase of understanding as an active construction of meaning. ${ }^{37}$ Construction implies a method, not random chaos. Even if meaning seems immediately given by the text, ${ }^{38}$ the actual process always starts with a human guess ${ }^{39}$

36 "The discipline of interpretation is founded, then, not on a methodology of construction but on a logic of validation." Hirsch, Validity in Interpretation, 207.

37 "The definitive proof that understanding requires an active construction of meaning and is not simply given by the text is the obvious fact that no one can understand an utterance who does not know the language in which it is composed." Hirsch, Validity in Interpretation, 134.

38 "In all cases, what we understand is a construction, and if the construction happens to be unthinking and automatic, it is not necessarily more vital and authentic for that." Hirsch, Validity in Interpretation, 43. The text both supports and constrains what the reader can construct. Though textual meaning is pluripotent, Ricoeur also recognized, "The text is a limited field of constructions." Paul Ricoeur, Hermeneutics and the Human Sciences, 213. Likewise, the physical world both supports and constrains new scientific theories. "Development of the theory is also shaped by the way the world is. So the way the world is constrains the way theory develops, which creates pressure for reshaping habits in ways that fit comfortably with what theory has become.” Margolis, Paradigms, 24.

39 "The notion that a reliable methodology of interpretation can be built upon a set of canons is thus a mirage. ... No possible set of rules or rites of preparation can generate or compel an insight into what an author means. The act of understanding is first a genial (or a mistaken) guess, and there are no methods for making guesses, no rules for generating insights. The methodical activity of interpretation commences when we begin to test and criticize our guesses." Hirsch, Validity of Interpretation, 203. Ricoeur agrees, "Why do we need an art of guessing? Why do we have to 'construe' the meaning? Not only -as I tried to say a few years ago-because language is metaphorical and because the double meaning of metaphorical language requires an art of deciphering which tends to unfold the several layers of meaning. The case of the metaphor is only a particular case for a general theory of hermeneutics. In more general terms, a text has to be construed because it is not a mere sequence of sentences, all on an equal footing and separately understandable. A text is a whole totality." Ricoeur, Hermeneutics and the Human Sciences, 211-213. 
about the whole idea or direction of the text. Without a guessing reader, the text remains a mute sequence of language symbols. ${ }^{40}$ Hirsch wrote, "Every interpretation begins and ends as a guess, and no one has ever devised a method for making intelligent guesses." ${ }^{41}$ Howard Margolis shares that the process of guessing is just as critical for scientific thinking: "Characteristically, the first (framing) stage does not involve an explicit process. Rather, the person is treated as somehow recognizing or imputing a particular way of seeing the problem, in a way that is not itself ordinarily subjected to analysis. Instead it is only at the second (judgment) stage that we get an analysis, and that comes in terms of a comparison with some normative standard of rational judgment." ${ }^{42}$

From where do these guesses come? From the repertoire of patterns and types in the personal worlds of meaning that the interpreter brings to the text. "If all cognition is reducible to sequences of pattern-recognition (and Patterns [Margolis' first book of the series] amounts to a long argument for that), then what a person can do at any particular moment is constrained by the repertoire of recognizable patterns currently available." ${ }^{43}$

40 "In fact, what is out there? There is just a series of signs. Anything over and above a re-issue of the same signs in the same order will be mediated by the experience, intelligence, and judgment of the interpreter." Lonergan, Method in Theology, 157.

${ }^{41}$ Hirsch, Validity in Interpretation, 170. Karl Popper agrees, "My view of the matter, for what it is worth, is that there is no such thing as a logical method of having new ideas or a logical construction of this process. My view may be expressed by saying that every discovery contains 'an irrational element,' or 'a creative intuition."' Karl Popper, The Logic of Scientific Discovery (New York, NY: Routledge, 2002), 8.

${ }^{42}$ Howard Margolis, Patterns, Thinking and Cognition: A Theory of Judgment (Chicago, IL: The University of Chicago Press, 1987), 5.

${ }^{43}$ Margolis, Paradigms and Barriers, 36. 
This explains why different interpreters see different meanings from the same text and why the same interpreter will see at a later time new meanings in a familiar text; "change in the cognitive repertoire is the heart of the matter." ${ }_{44}$ Since these guesses come from the interpreter's worlds of meaning, self-disclosure of relevant repertoire ${ }^{45}$ may further empathetic understanding of opposing points of view. ${ }^{46}$

Is guessing completely random? No, textual "cues appear critical to prompting that pattern" ${ }^{47}$ and help to tailor the guesses. Micro-hermeneutics exposes a myriad of objective cues from the text and their possible implications for meso-hermeneutical construction. For instance, authorial emphasis emerges if a literary structure is validated ${ }^{48}$ and variations in narrative repetition may convey a nuanced appraisal of two comparable situations. This is the literary hermeneutical circle that relates textual parts to the whole biblical passage through the flat spiraling circuit of the interpreter ranging across the

${ }^{44}$ Margolis, Paradigms and Barriers, 207.

${ }^{45}$ David Rennie, "Qualitative Research as Methodical Hermeneutics," Psychological Methods 17, no. 3 (2012): 392 .

${ }^{46}$ Hermeneutics is not limited to interpreting texts but also analyzes the interpretive process itself. Thus, it also seeks to promote a "more sympathetic understanding of views and arguments that at first seem alien or unacceptable. Hermeneutics seeks to establish bridges between opposing viewpoints. This does not necessitate giving ground to the other view, but sympathetically to understand the diverse motivations and journeys that have led in the first place to each respective view or argument." Thiselton, Hermeneutics, 6.

${ }^{47}$ Margolis, Paradigms and Barriers, 204.

${ }^{48}$ I beg to differ from Ricoeur when he says, "There is no necessity and no evidence concerning what is important and what is unimportant, what is essential and what is unessential. The judgement of importance is a guess." Ricoeur, Hermeneutics and the Human Sciences, 211. It may be a guess initially, but it can be tested. If a literary structure is discerned in the text and coheres with further analysis of the whole pericope, what is important or unimportant in the text according to the original vision of the narrator can be validated. 
ramp of biblical worlds of meaning. The second hermeneutical circle fuses the horizons of the text and the interpreter by weaving from the personal worlds of meaning to the textual worlds of meaning and back again. Exactly how textual cues and the interpreter's pattern recognition mesh remains an unsolved problem ${ }^{49}$ but the two iterative movements from textual cues to the whole text and from a pattern of meaning from the interpreter's worlds of meaning to the text then back again is jointly assumed in the hermeneutical method for understanding.

Because these two methods of circularity are how humans apprehend meaning from texts, an accusation of eisegesis reveals a simplistic and modernist presupposition of a clear, acknowledged boundary separating exegesis and eisegesis. There is no normative universal criteria for where that imaginary line is, though many have intuitive hunches for where they believe it ought to be. Hermeneutics necessitates the overlapping spectrum of text and interpreter which only excludes the polar extremes of text or interpreter in isolation (see Fig. 4.3 below). Of course, different schools of thought stake the limits of acceptable proposals along this spectrum with good reasons for doing so. But a random

${ }^{49}$ Margolis, Patterns, Thinking and Cognition, 2. 
accusation of eisegesis only reveals in reverse, a personal discomfort with the accused overstepping the accuser's comfort zone for interpretation.

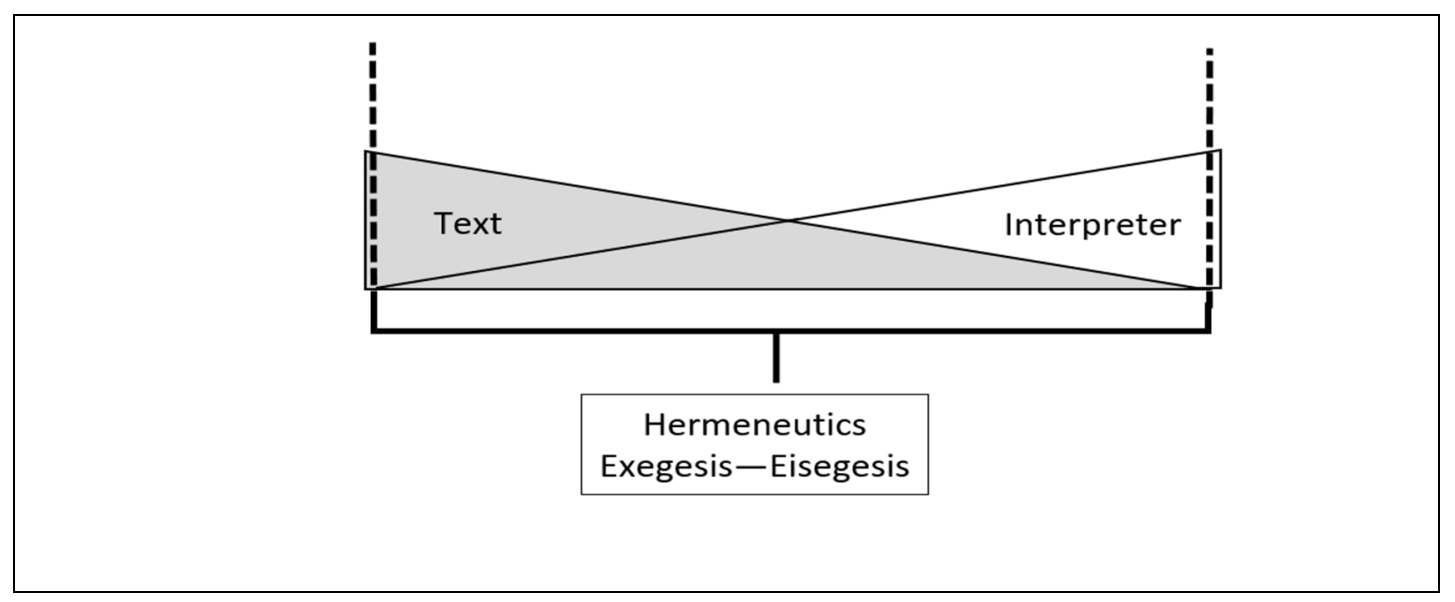

Fig. 4.3 Hermeneutical scope for meaning

On a larger scale, faith communities assume their own interpretive boundaries are self-evident, often without self-awareness. The Christocentric insistence of Christian interpreters on the Hebrew Bible or Old Testament texts is certainly considered eisegesis by Jews. The Koran based filter of Muslim theologians on the New Testament is called eisegesis by Christians. Feminist, Liberation and Ethnic perspectives are called eisegesis by conservative denominations, who may use inerrant or infallible filters in their textual exegesis. Instead of labels, explaining the principles and arguments behind discomfort with a proposed interpretation is more helpful and builds cognitive bridges across faiths 
and denominations, leading to correct understanding of alternative positions from their framework of orthodoxy and reasonableness without compromising one's own.

Within such parameters, what forms a group's understanding of a text? Gadamer called the process—-harmonizing: "The movement of understanding always runs from the whole to the parts and back to the whole. The task is to expand in concentric circles the unity of the understood meaning. Harmonizing all the particulars with the whole is at each stage the criterion of correct understanding. Its absence means the failure to understand." ${ }^{50}$ Ricoeur recognized the bi-directional orchestration to this process: "The reconstruction of the text as a whole necessarily has a circular character, in the sense that the presupposition of a certain kind of a whole is implied in the recognition of the parts. And reciprocally, it is in construing the details that we construe the whole." ${ }^{\prime 1}$ This means the harmonizing hermeneutic method is vulnerable to confirmation bias ${ }^{52}$ which can turn the hermeneutic circle into a mental trap for "an interpretive hypothesis ... tends to be a self-confirming hypothesis. Thus, the distressing unwillingness of many interpreters to relinquish their sense of certainty is the result not of native close-mindedness but of imprisonment in the hermeneutic circle." ${ }^{33}$ Accordingly, the result of harmonizing,

${ }^{50}$ Hans Georg Gadamer, "On the Circle of Understanding" in Hermeneutics Versus Science? Three German Views, eds. J. M. Connolly and T. Keutner (South Bend, IN: University of Notre Dame Press, 1988), 68.

${ }^{51}$ Paul Ricoeur, "The Model of the Text: Meaningful Action Considered as A Text," New Literary History 5, no. 1 (1973): 106.

52 "The tendency to test one's beliefs or conjectures by seeking evidence that might confirm or verify them and to ignore evidence that might disconfirm or refute them." Oxford Dictionary of Psychology, $4^{\text {th }}$ ed. (2015) s.v. "confirmation bias,"

${ }^{53}$ Hirsch recognizes the implications of this phenomenon: "Literary and biblical interpreters are 
internal coherence alone cannot discriminate between a correct understanding and a cohesive circle of illusion. ${ }^{54} \mathrm{~A}$ second criteria of internal correspondence may help to arbitrate between competing coherent interpretations, based on how well one "makes functional the elements of the mute text than a rival hypothesis." ${ }^{55}$ These two internal criteria of coherence and correspondence constitute the internal validity of an interpretation. However, to gain widespread interpretive plausibility—which requires an intuitive correspondence to external reality - three additional hermeneutical heuristics are helpful.

The three heuristics are (1) the Principle of Charity, (2) the Principle of Humanity and (3) Occam's Razor. The first, the hermeneutical Principle of Charity, recommends maximizing coherence and self-consistency in interpreting the words and actions of others. Willard Van Orman Quine articulated the Principle of Charity for critical translation: "The maxim of translation underlying all this is that assertions startingly false

not by nature more willful and un-self-critical than other men. On the contrary, they very often listen patiently to contrary opinions, and after careful consideration, they often decide that the contrary hypothesis 'do not correspond to the text.' And of course, they are right. The meanings they reject could not possibly arise except on the basis of a quite alien conception of the text. After all, since the text is largely constituted by the hypothesis, how could the hypothesis fail to seem inevitable and certain?" Hirsch, Validity in Interpretation, 166. Heidegger referred to this bias confirmation phenomenon of the hermeneutic circle as the famously coined "vicious circle." Heidegger, Being and Time, 152.

${ }^{54}$ Taylor believed all interpreters should be self-critical, "How can I be sure? Maybe my intuitions are wrong or distorted, maybe I am locked into a circle of illusion." Taylor, "Interpretation and the Sciences of Man," 5-6. This subjective circle of self-confirming coherence within a pericope points to the need for an external norm for validity.

${ }^{55}$ Hirsch, Validity in Interpretation, 190. 
on the face of them are likely to turn on hidden differences of languages." ${ }_{56}$ Donald Davidson's hermeneutical version of the above maxim is "Charity in interpreting the words and thoughts of others is unavoidable in another direction as well; just as we must maximize agreement, or risk not making sense of what the alien is talking about, so we must maximize the self-consistency we attribute to him, on pain of not understanding him. $" 57$ The second heuristic, the hermeneutical Principle of Humanity, recommends an approach where "one should attribute to a creature the propositional attitude one supposed one would have oneself in those circumstances." ${ }^{58}$ The third heuristic, Occam's Razor, was originally articulated as an ontological maxim: "Entities are not to be multiplied without necessity." ${ }^{59}$ Applied to hermeneutics this means if two options for interpretation are comparable in explanatory power, the simpler option is to be preferred.

Using these two internal literary criteria and three intuitive heuristics, the following section on understanding the Aqedah will proceed in this manner. First, I will attempt to construct a theocentric viewpoint of the Aqedah as the primary thesis from the text. Next, the anthropocentric viewpoint from the text will be presented as the alternate thesis. Then, the final form of the Aqedah text will be analyzed as the biblical synthesis

${ }^{56}$ W. V. O. Quine, Word and Object (Cambridge, MA: MIT Press, 1960), 54.

${ }^{57}$ Donald Davidson, Inquiries into Truth and Interpretation (Oxford, UK: Oxford University Press, 1984), 27.

${ }^{58}$ Daniel Dennett, The Intentional Stance (Cambridge, MA: MIT Press, 1987), 343. Together, the Principle of Charity and the Principal of Humanity resonate with Schleiermacher's hermeneutical principle of divination, a psychological or empathic understanding of the text as the words of a human author who lived in the same shared world of the reader.

${ }^{59}$ Quoted in Boehm, Binding of Isaac, 8. 
of these two viewpoints. ${ }^{60}$ For this work, the Bible translation for this chapter and all the remaining chapters of this dissertation will utilize the Revised Standard Version for its accuracy in capturing the meaning of the original Hebrew.

\section{Application: Understanding}

Thesis: Theocentric viewpoint

The construction of a theocentric viewpoint of the Aqedah will be through the hermeneutic method described above. Usually this construction is done privately and informally then publicly argued in a logically linear fashion that leaves the discovery process inscrutable and black-boxed to readers. To be transparent, I will demonstrate the

\footnotetext{
${ }^{60}$ Even though Hegel never used the terms of thesis, antithesis and synthesis, Hegel's triadic pattern has been labeled with these terms by tradition. If this triadic is adapted for hermeneutics, it would envision a process where a particular interpretation or thesis is asserted, the anti-thesis refers to the negation or competing interpretation to the first, then synthesis is the reconciliation of the two that forms a "newer, fuller, and more informed interpretation or understanding - the Hegelian synthesis or Gadamerian "fusion of horizons." David Schwartz, Encyclopedia of Knowledge Management (Hershey, PA: Idea Group Reference, 2006), 8. The terms I will use in this dissertation is thesis for the theocentric viewpoint, alternative thesis for the anthropocentric viewpoint and synthesis for the complementary conjoining of the two. The term alternative thesis is more accurate for Abraham's perspective because he is not a negation for God and his motive is not in contradiction to the divine will (v. 11 Now I know you fear God). Instead, his actions align with the test command literally, while his understanding of the divine will behind the test command differs only on one point. So, as a learning, disciple-servant of God, Abraham's viewpoint matches God's viewpoint all the way until his grasping of the knife to kill his son—one significant departure, though done in faith. The interaction in Genesis 17 also shows a similar pattern of divergence between the two on only one point (Abraham's wrong assumption that Ishmael was the promised son) that was readily corrected by Abraham when God made it clear.
} 
informal, creative and intuitive hermeneutical method as directed by the text and my constructive approach will remain literary, theological and historical. ${ }^{61}$

By means of the first verse, the narrator explicitly posits the proper paradigm for understanding ${ }^{62}$ the Aqedah: "After these things God tested Abraham and said to him, ‘Abraham!' And he said, 'Here I am”” (Gen 22:1). This verse indicates that Aqedah should be understood (a) in the context of the preceding Abrahamic stories (after these things), as involving (b) two viewpoints ${ }^{63}$ (God tested Abraham) - Tester and testee - in (c) one test, (d) with emphasis on God the Tester (grammar with definite article, emphatic syntax reversal order) over Abraham the testee for the nature of this test (e) with dialogue

${ }^{61}$ Source-historical aspects of the text were addressed in chapter 3 on the micro-hermeneutical level. The historical aspect of this present meso-hermeneutical journey will focus on the previous stories of the literary Abrahamic cycle in the canon as background.

${ }^{62}$ One way to make certain that this introduction by the narrator is taken seriously is to ask oneself, what concept would be missing from consideration if this phrase, term, or syntax wasn't present? The same exercise from the opposite direction is to reduce the sentence to its minimum proposition (God tested Abraham), then note what is added to the core meaning by each un-essential elaboration.

${ }^{63}$ Though one united viewpoint would be ideal, Boehm admits, "the present literature on Gen 22 . . . lacks one simple interpretation that elegantly resolves the various difficulties found in the text." Omri Boehm, The Binding of Isaac, 8. Albert Einstein recognized minimum limits to simplification when he wrote, "It can scarcely be denied that the supreme goal of all theory is to make the irreducible basic elements as simple and as few as possible without having to surrender the adequate representation of a single datum of experience." Albert Einstein, "On the Method of Theoretical Physics," Philosophy of Science 1, no. 2 (April, 1934): 165. This was later summed up by Alice Calaprice as "Everything should be made as simple as possible but not simpler." Alice Calaprice The New Quotable Einstein (Princeton, NJ: Princeton University Press, 2005), 290. Since God is the Tester and Abraham is the testee and there is admittedly a vast difference between the intelligence and nature of the two beings, at a minimum two viewpoints appear necessary to adequately understand the epistemology of this event of Divinity testing His creature. 
as the divine mode of engagement that required Abraham to appropriate (Here I am) his covenant identity (Abraham!). ${ }^{64}$

The (a) contextual phrase, "after these things [it happened]"65 can indicate conjunctive or disjunctive framing. However, conjunction of the Aqedah with the previous covenant journey is the only way to see the test as a problem. In disjunctive isolation from its context, the Aqedah is neither a theological problem nor a discovery. It is only a problem if it "puzzles and worries somebody" and a discovery only if it "relieves somebody from the burden of a problem." ${ }_{66}$ Since the problematic nature of the test is a core assumption in the Aqedah literature, I will plumb the conjunctive approach to appreciate the difficulty of the test and to try to resolve the tensions in the narrative. ${ }^{67}$

${ }^{64}$ Gadamer believed praxis-oriented legal, normative or biblical texts require appropriation from the very beginning of the process for correct understanding: "We too determined that application is neither a subsequent nor merely an occasional part of the phenomenon of understanding, but codetermines it as a whole from the beginning." Gadamer, Truth and Method, 333; See also Jean Grondin, "Gadamer's Basic Understanding of Understanding" in The Cambridge Companion to Gadamer, ed. R. Dostal (Cambridge, UK: Cambridge University Press, 2002), 36-51. Appropriation begins when we accept that "the most important thing is the question that the text puts to us, our being perplexed by the traditionary word so that understanding it must already include the task of the historical self-mediation between the present and tradition. ... In order to answer the question put to us, we the interrogated must ourselves begin to ask questions." Gadamer, Truth and Method, 382.

${ }^{65}$ Where the RSV version of the narrative leaves out Hebrew terms and it is helpful to the point being made, I will supply the missing translation in brackets.

${ }^{66}$ Michael Polanyi's germane example of this point is "a chess problem means nothing to a chimpanzee or to an imbecile and hence does not puzzle them; a great chess master on the other hand may fail to be puzzled by it because he finds its solution without effort; only a player whose ability is about equal to the problem will find intense preoccupation in it. Only such a player will appreciate its solution as a discovery. It appears possible to appraise the comparative hardness of a problem and to test the intelligence of subjects by their capacity for solving problems of a certain degree of hardness." Michael Polanyi, "Problem Solving," The British Journal for the Philosophy of Science 8, no. 30 (August 1957): 92. The Aqedah testing speaks well of Abraham for God thought it equal to Abraham's capacity to understand and succeed.

${ }^{67}$ Illogically, most theological treatments initially assume a conjunctive stance to elaborate the vexing moral conundrum of the Aqedah, then proceed to ignore the preceding narratives and try to resolve 
The conjunctive stance assumes God as the divine Tester to be consistent with His revealed benevolent character and accepts the biblical record as truthful about the divine source issuing the demand for human sacrifice. ${ }^{68}$ Then human reason must keep listening ${ }^{69}$ to the story until the natural end of the telling, without rejecting any part of Scripture.

How should understanding be pursued, what method is appropriate for the Aqedah? The divine Tester employed the (e) dialogical ${ }^{70}$ method with Abraham to start the test and this interactive approach is similar to the bi-directional hermeneutical

the problem of the Aqedah in disjunctive isolation from the covenant context. This move routinely leads to ahistorical abstract philosophical concepts to make sense of the test. Context is critical for appropriate interpretation. Howard Margolis' demonstration of this maxim is superb: "To interpret the meaning of 'or' one must know the context: i. Soup or salad (waiter-neither, or either but not both), ii. $\$ 100$ or 10 days (judge - either, not neither, not both), iii. Cream or sugar (hostess — either, neither, or both), iv. Wash or sweep (parent to child — either or both, not neither)." Margolis, Patterns, Thinking and Cognition, 94.

${ }^{68}$ In contrast to this stance, Immanuel Kant argued: "If God should really speak to man, man could still never know that it was God speaking. It is quite impossible for man to apprehend the infinite by his senses, distinguish it from sensible beings, and recognize it as such. But in some cases man can be sure that the voice he hears is not God's; for if the voice commands him to do something contrary to the moral law, then no matter how majestic the apparition may be, and no matter how it may seem to surpass the whole of nature, he must consider it an illusion." In a footnote Kant specifically added: "We can use, as an example, the myth of the sacrifice that Abraham was going to make by butchering and burning his only son at God's command (the poor child, without knowing it, even brought the wood for the fire). Abraham should have replied to this supposedly divine voice: 'That I ought not kill my good son is quite certain. But that you, this apparition, are God —of that I am not certain, and never can be, not even is [read: if] this voice rings down to me from (visible) heaven." Immanuel Kant quoted by Stephen R. Palmquist and Philip McPherson in "Three Perspectives on Abraham's Defense against Kant's Charge of Immoral Conduct," The Journal of Religion 89, no. 4 (October 2009): 471-472.

${ }^{69}$ Abraham exemplified active listening with obedience to the end and was divinely commended at the end of the test with the approbation, "You obeyed my voice."

${ }^{70}$ The method of provocative questions and answers is sometimes referred to as the Socratic dialectic, but I have no interest in importing Socrates' "apparent intention of convicting his interlocuters of their inability to answer the question rather than with the intention of supplying the answer." Alasdair MacIntyre, A Short History of Ethics (New York, NY: The Macmillan Company, 1966), 20. Instead, I am following the question and answer methods of Jesus (Matt 6:26-30; 12:10-11; 21:23-27; 22:41-45) who used questions to prepare a receptive space in the hearers' heart and mind to comprehend the answer better. 
method. A call or question works by creating a receptive opening in the listener for understanding. Heidegger likened understanding to an opening, a clearing that allows for authentic sight. ${ }^{11}$ Likewise, Abraham's answer to God "Hinneni" (lit. behold me) conveys a receptive invitation for God to see him, with Abraham simultaneously open to whatever God wants to disclose of Himself..$^{72}$ This simple yet profound exchange of mutual openness is characteristic of an "I-Thou" 73 relation and anchors the three angles of the Aqedah literary structural triangle. It thus seems appropriate to accept the congruence between the hermeneutical method of questions and answers and the divine dialogical method of the test to understand the Aqedah. This hermeneutical understanding will be

\footnotetext{
71 "In the analysis of understanding and the disclosedness of the there in general, we referred to the lumen naturale and called the disclosedness of being in the clearing of Da-sein in which something like sight first becomes possible. Sight was conceived with regard to the basic kind of disclosing characteristic of Da-sein, understanding in the sense of the genuine appropriation of beings to which Da-sein can be related in accordance with its essential possibilities of being." Heidegger, Being and Time, 159. Da-sein was Heidegger's invented term for the experience of Being that is peculiar to human beings, a form of understanding.

72 "Gadamer argues that the 'logical structure of openness' is to be found in the model of the Platonic dialogue, or to be more accurate, in the Socratic dialectic of question and answer. In order to effect a 'fusion of horizons' between the horizon of the interpreter and the object of his interpretation, a dialogue takes place between the individual and the phenomenon of interest. However, the interpreter must be aware of his prejudices and recognize that his knowledge is not absolute but incomplete-he must be 'open' to the phenomenon." Tom Butler, from Table 1: A Taxonomy of Dialectic Techniques for Hermeneutic Research in "Towards a Hermeneutic Model for Interpretive Research in Information Systems" in Journal of Information Technology, (1998): 290.

${ }^{73}$ There is a difference between encountering the other through the senses only ("I-It") and relating to the other in an authentic, living, profoundly positive way ("I-Thou"). The second encounter is what makes me - really me. "I become through my relation to the Thou: as I become $I$, I say Thou." Martin Buber, I and Thou, trans. Ronald Gregor Smith (New York, NY: Continuum, 2004), 17.
} 
constructed through dialog by asking questions, then listening to (or more accurately, searchingly reading then contemplating deeply) the answers provided by the text.

What is the Aqedah? Verse one announces the self-organizing narrative to be a (c) divine test ${ }^{74}$ between (b) two participants. Though this is an ancient, puzzling, unrepeatable test and I have no direct access to the mind of the narrator, because the narrator chose to frame the Aqedah as a test, to understand this text it is absolutely necessary to guess ${ }^{75}$ at what characteristics of a test the narrator and I might hold in common. Then the hermeneutical method requires me to return to the text to validate or invalidate those guesses. ${ }^{76}$

The term test is a textual cue that cannot help but evoke my practical experience of tests as a possible intuitive backdrop to the reading of the Aqedah. For instance, the

${ }^{74}$ Test qualifies as a language game in the Wittgensteinian sense of the term for it is a semiotic social convention of language and actions woven together that is recognizable, but not rigid. Ludwig Wittgenstein, Philosophical Investigations, trans. G. E. M. Anscombe (Oxford, UK: Basil Blackwell, 1986), 2 [3]. A recognizable social convention assumes initiator and responder share a history, vocabulary, purpose and pattern of interactions. Thus, for the reader to be able to hear God's test command as Abraham heard it, requires the reader to be seeped in Abraham's past covenant journey and keep it in mind as a hermeneutic grid to understand the test.

${ }^{75}$ All previous biblical studies on test (nissah) from the micro-hermeneutical level are now incorporated as part of my personal worlds of meaning and provide the exegetical backdrop for mesohermeneutical guesses. To avoid redundancy in this project, connections from personal testing experience are highlighted in this meso-hermeneutical chapter to add to the already growing exegetical understanding of the Aqedah. The findings from the last chapter will be assumed to be already in place and active as background textual information.

${ }^{76}$ The biblical pericope will be used as the most universally available standard to support and narrow the scope of test meanings brought into this study. Of course, the term test carries multiple implications and "the generation of implications depends on the interpreter's previous experience of the shared type." Hirsch, Validity in Interpretation, 66. This is shown by the disagreement between Jon Levenson and Nahum Sarna on whether the term test implies or doesn't imply that the threat to Isaac's life was genuine, this difference in test implications does not stem from the Hebrew term itself but from their previous experiences related to the concept of a test. See Sarna, Genesis, 393; Levenson, Death and Resurrection, 126. 
Aqedah is shrouded in Abraham's silence as evinced by Isaac's question. ${ }^{77}$ This is not surprising to me, for almost every test in my life was taken in silence. Silence is the normal mode for tests. Typically, the tester's silence stems from confidence that adequate preparation has been given before the test and that further help is not necessary for successful completion..$^{78}$ The testee's silence may indicate confusion, numbness, and despair but it may conversely signal active interest, reflection, pondering, reasoning, and alert attentiveness ${ }^{79}$ to any new directions from the tester to correct or clarify the test further.

Though Abraham had not been afraid in the past to morally protest a judgment from God (Gen18), the unusually intuitive Abraham who had become God's friend may have sensed from the rhetorical aspects of the divine communication and unusual demand

\footnotetext{
${ }^{77}$ Many reasons have been offered for Abraham's silence: shock, horror, disgust, numbness, grim obedience. But according to Kierkegaard, Abraham's silence is the solitary suffering of carrying out a mission that nobody could or would understand because it was unrelatable and done in absolute relation to the Absolute. Abraham cannot speak because even speaking would not have made his actions understandable, in fact, being understood would have been a temptation to make God's order subservient to universal human maxims. Kierkegaard even regards Abraham's speech to Isaac about God offering Himself a lamb as ironic because it is a non-answer, according to him. Kierkegaard, Fear and Trembling, 142. What Kierkegaard and most theologians are assuming correctly in noting the unusual silence of Abraham is that Abraham has not been shy about voicing moral protests to God in the past. But could it be that they underestimate Abraham's ability to sense this divine communication is different in nature from all the rest because it targets his deepest fear?

${ }^{78}$ The idea of God's silence and hiddenness in such tests is implied in II Chron 32:31: "God left him [Hezekiah] to himself, in order to test him and to know all that was in his heart." Even when Hezekiah took the wrong choice and failed the test, no divine mid-test correction was given, only a judgment at the end. See 2 Kgs 20:12-19; 2 Chron 32:27-31. In the case of Abraham's test, God intervened because Isaac's life, and therefore the covenant was at stake.

${ }^{79}$ During a verbally directed performance test of surgical knot-tying in an ob-gyn clinical rotation, a slight shift in seating position by an examiner caught my hyperattentive hearing and I looked up immediately to see if he was giving me nonverbal indications that I was doing it wrong. He smiled at me reassuringly, so I went back to my task. Abraham likewise happened to be in a verbally guided performance test.
} 
that this was a trial or examination completely different from past revelations and he may be responding accordingly with soul-searching silence. In addition, Abraham's silence may signal a hyperattentive listening mode since God had specifically promised further communication $^{80}$ (which I shall tell you, v. 2). If he was also hoping for a possible reprieve, that would be another reason to keep the matter to himself instead of sharing it prematurely with others. Though we cannot and should not rule out emotional reasons for Abraham's silence, I find the text-provided paradigm of an auditory-guided test with pending instructions has strangely never been proposed as a plausible reason when it is the most obvious. God calling Abraham by his covenant name, a first, conveyed to the highly intuitive ${ }^{81}$ Abraham that something unusual and very serious was happening even if he wasn't told explicitly that this was a test. Silent, hyper-attentive listening is later proven by Abraham's instantaneous mid-action reversal reaction to the angelic interruption (v. 11).

A second characteristic from my testing experience also resonates with textual cues from the Aqedah. As every student knows, a tester usually knows the purpose of

${ }^{80}$ The Bible records God can speak very softly, perhaps even articulating a thought through silence: "And after the earthquake a fire, but the Lord was not in the fire. And after the fire the sound of a low whisper" (1 Kgs 19:12). In Abraham's covenant journey, the nighttime conversation about counting the stars fit that gentle mode: "And he [God] brought him outside and said, 'Look toward heaven, and number the stars, if you are able to number them.' Then he said to him, 'So shall your offspring be"' (Gen 15:5). Since the Aqedah command was probably a nighttime revelation beginning with $n a$ (please or now), a quiet communication is a possibility and if so, it would engender Abraham's hushed listening mode, straining to catch the next whisper from God as promised (Gen 22:2).

${ }^{81}$ In Gen 18:21, 23, God only mentioned investigating the truth about the outcry from Sodom and Gomorrah and didn't outline any planned actions, but Abraham intuited that God would find them evil, judge them, and destroy the city. Their ensuing dialogue demonstrates that Abraham's highly sensitized spiritual intuition about YHWH was correct and the events of Gen 19 underline it. 
their test better than the testee (d). In fact, a consistently successful testee will not only try to understand the actual test directions but also intuit what the tester is trying to measure by means of the test. Test requirements must be handled capably to pass, ${ }^{82}$ but this gap between the tester's knowing and testee's guessing regarding the test purpose suggests that logical alignment of the divine Tester's actions ${ }^{83}$ in the Aqedah may reveal the original purpose ${ }^{84}$ of the test better than following the wake of Abraham's reactions. ${ }^{85}$

\footnotetext{
${ }^{82} \mathrm{~A}$ test must be satisfied in some manner. If there is ambiguity or confusion in the design of the test and the testee correctly senses what the tester is trying to assess, a clever testee will overwhelm the inadequate test options by choosing the best available and adding a side notation to demonstrate their knowledge or skill, thereby providing what they think the tester is trying to assess. The learner's knowledge of the tester is demonstrated by their response to ambiguous/unusual aspects of the tests from the tester. What does this say about Abraham?

${ }^{83}$ Most of my personal test experiences are not germane to the text and were eventually ruled out by the text norm, but two experiences matched the Tester's actions in the Aqedah text and opened tentative possibilities for understanding. I took tests from a chemistry professor who was renowned for posing test questions that were completely unlike the homework assignment problems but required the comprehensive understanding and integration of several cognitive processes taught in the homework in order to solve the unique test problems. Another physics professor was unusual in that he would make himself available for mid-test redirection if a student was stumped during a test. Silently, he would correct or re-direct the student's work with a red pen thereby allowing the student to successfully complete the problem and those red marks were incorporated into the grading of the test.

84 "The unifying and controlling idea in any type of utterance, any genre is the idea of purpose." Hirsch, Validity in Interpretation, 110. The assumption here is that the Tester's unstated purpose for the test can be discerned as the consistent direction or trajectory of His words and actions in the Aqedah.

${ }^{85}$ Traditional Aqedah theology tends to be anthropocentric, focused and elaborating on Abraham's actions and words over God's words and actions. This may be because Abraham was commended by God as having passed the test and the interpreter automatically identifies with Abraham's anguish when confronted by the harsh test command. But both test logic and principles of biblical exegesis point to God as the most reliable reference in this story for what the test is about.
} 
Using Occam's Razor, ${ }^{86}$ I will attempt to reconstruct a logically linear ${ }^{87}$ theocentric understanding of the Aqedah if possible.

For tracing God's actions in the Aqedah test where should one begin? Perplexity regarding a test is usually addressed by the tester at the end of the test experience. The literary structure of the Aqedah had suggested God's last speech (vv. 16-18) was a divine interpretation or commentary on Abraham's actions (v. 16 “because you did this thing"). ${ }^{88}$ Since the last divine speech is an interpretation of the test, it differs in style from the terse test narrative. ${ }^{89}$ This final divine word in the Aqedah re-establishes the covenant on God Himself then lists themes and blessings corresponding to six of the seven previous covenant revelations to Abraham as we have seen on the microhermeneutical level of analysis. As a divine interpretive assessment of Abrahams' test

\footnotetext{
${ }^{86} \mathrm{~A}$ simpler or logical non-contradictory, non-retracting test hypothesis would be preferred, if found, over a contradictory or self-retracting explanation for God's actions.

${ }^{87}$ If a logical linear progression of theocentric actions in the Aqedah can be constructed that is equal in explanatory power to the traditional interpretations that assume God retracted or pulled back His test command, it would be aesthetically simpler and preferable.

${ }^{88}$ R. W. L. Moberly, "The Earliest Commentary on the Akedah," in Vetus Testamentum 38, no. 3 (July 1988), 312, 318. A test interpretation functions as a test assessment, an explanation.

${ }^{89}$ At the end of Hezekiah's test, II Kings 20:12-18, Isaiah delivers an assessment in a very different style from the curt staccato questions used in the debriefing just prior to it. After Job's trial, God's assessment of their conversation (Job 42:7-8) is delivered to Eliphaz in narrative style also very different from His oratorical browbeating of Job in the whirlwind.
} 
response, this is the closest objective indication in the text of the Tester's purpose ${ }^{90}$ for

the Aqedah.

What was the divine purpose of the Aqedah? ${ }^{91}$ According to the final divine

interpretation in vv. 15-18 that references Abraham's test actions and evaluates it against

the norm of previous covenant revelations, one logical interpretative hypothesis for the

purpose of the test is that it was testing the integration of Abraham's covenant identity by

eliciting a comprehensive covenant-based response from the divinely trained Abraham.

That is, the divine test command which threatened to end the covenant through the

required sacrifice of Isaac may have been designed to be solved by a paternal covenant

response from Isaac's father, the first prophetic intercessor and covenant father of God's

${ }^{90}$ Hirsch claims that "the author's intention is the single meaning of the text." Hirsch, Validity in Interpretation, 133-144. Because the author's intention is rarely accessible as a norm outside the text or directly explicated in the text, I appreciate Anthony Thiselton's observation that the "directedness" or "intentional directedness" of the text has been accepted as its nearest representation. Thiselton, Hermeneutics, 27. Kevin Vanhoozer agrees with Thiselton, "the text stands between author and reader as an embodied intention, that, through various textual strategies, extends the matter and mode of the author's attention to the world into the world of the reader, enabling the reader to respond to the same matter in an appropriate fashion." Kevin Vanhoozer, Is there Meaning in this Text? The Bible, the Reader, and the Morality of Literary Knowledge (Grand Rapids, MI: Zondervan, 1998), 282. See also David E. Klemm, "Introduction," 35 and Teruhiko Nagao, "On Authorial Intention: E. D. Hirsch's Validity in Interpretation Revisited,” The Annual Reports on Cultural Science 40, no. 1 (November 1991): 161-180.

91 The divine purpose for the Aqedah has historically generated many conjectures: (1) Satan accuses Abraham of ingratitude after Isaac's birth - God counters by saying Abraham would obediently offer the child and tests him. Rabbi Yossi ben Zimra in Sanhedrin 89b, Babylonian Talmud, (2) Prince Mastema asks God to test Abraham's faithfulness and love since he now has a son he loves and "is more pleased with him than everything." O. S. Wintermute, "Jubilees: A New Translation and Introduction," in J. H. Charlesworth, The Old Testament Pseudepigrapha, vol. 2 (New York City, NY: Doubleday, 1985), 35142, esp. 90, (3) All the angels and heavenly host were jealous of Abraham because of God's miracle gift to him, so God tells him to give up "the fruit of your body." Biblical Antiquities of Pseudo-Philo, 32:1-2 as quoted by I. Kalimi, “Go, I Beg You, Take Your Beloved Son and Slay Him!: Binding of Isaac in Rabbinic Literature and Thought," Review of Rabbinic Judaism 13 (2010), 1-29, (4) Ishmael and Isaac are contending over who is more righteously deserving to inherit the birthright, Isaac asserts at 37 years old if God were to "demand all my members I would not hesitate." So, the Lord does. Targum Pseudo-Jonathan on Gen 22:1. My contribution remains text-based and text-normed in searching for the divine purpose. 
chosen nation, using an integration of all of the seven covenant revelations that preceded the test. ${ }^{92}$

Now, if the Aqedah was testing Abraham 's covenant identity through his response, how does that relate to the leitmotif of divine seeing/providing that runs throughout the narrative? All that Abraham is and could be, stemmed from his divinelyguided covenant journey. Even from the beginning, God had provided Himself as a paternal mentor to Abram after separating him from his biological father, his kinsmen and his country, seeing in him the beginning of a great chosen nation..$^{93}$ Through a covenant journey (lek-lekha: go for/to/into/with yourself, Gen 12:1, 22:2), God had transformed an obedient barren Abram into the covenant father Abraham, educating and training him through seven covenant revelations. ${ }^{94}$ The Aqedah divine interpretation

${ }^{92}$ Based on the first verse and norm for the grading of the test, the main purpose of the Aqedah is the testing of Abraham's covenant identity. Related implications may include: (1) contrasting pagan and Yahweh fathers in regard to child sacrifice as worship, (2) confronting and curing Abraham's persistent fear of death, (3) initiating Isaac into the covenant, (4) fulfilling God's promise of substitutionary selfimprecation to preserve the covenant with the provided ram-Gen 15, (5) revealing Abraham's fear of God and obedience to God's voice, (6) demonstrating divine graciousness by praising Abraham while not covering up Abraham's imperfections, (7) establishing the covenant on Himself while blessing Abraham relative to his covenant obedience, and (8) setting up a paradigm of meaning for the sacrificial services culminating in the Day of Atonement.

${ }^{93}$ A test functionally uncovers present capacity, identity in terms of motives, and hints at teleology. Why is someone the way they are? How did they come to be this way? What drives them to continue in such a way? "The goal of testing is an understanding of what a person can do, what one really has in oneself, and who one is." Theological Dictionary of the Old Testament Vol. IX, s.v. הo, eds. G. Johannes Botterweck, Helmer Ringgren, Heinz-Josef Fabry (Grand Rapids, MI: Eerdmans, 1998), 444. The test will exhibit to what extent Abraham has fulfilled the spiritual potential that God called him to personify.

${ }^{94}$ Gen $12: 1-3 ; 12: 7 ; 13: 14-17 ; 15 ; 17 ; 18 ; 21: 12-13$. 
(22:15-18) indicates that Abraham had internalized and integrated into his covenant identity six of the seven revelatory lessons as actualized in his test response.

At this point, it must be remembered that most tests do not end with perfect scores. In fact, a consistently perfect score can indicate that the tester is not adequately assessing the maximum potential of the testee. Thus, the prospect of Abraham achieving an imperfect performance is not to be taken as something negative. It can be rightly understood as underscoring the skill and knowledge of the Tester in disclosing the upper limits of Abraham's covenant maturity. Once hidden limitations are made explicit through testing, the testee can see his or her true condition and has the opportunity to master the missing component more deeply than before. Thus testing can be pedagogical in a profoundly effective and remedial way. What else in the text backs the possibility that the Aqedah was about testing the covenant identity of Abraham? The test begins with 
God and Abraham affirming his covenant identity: "After these things God tested

Abraham and said to him, 'Abraham!' And he said, 'Here I am"” (Gen 22:1). ${ }^{95}$

If this abductive hypothesis ${ }^{96}$ of the Aqedah testing Abraham's covenant identity

is correct, it should predict the test command details. ${ }^{97}$ Charles S. Pierce offered this

formulation for abductive reasoning:

The surprising fact, $\mathrm{C}$, is observed;

But if A were true, $\mathrm{C}$ would be a matter of course

Hence, there is reason to suspect that $\mathrm{A}$ is true. ${ }^{98}$

For our purposes, $\mathrm{C}$ is the Aqedah test command. If $\mathrm{A}$, the abductive hypothesis

that the Aqedah was a test of Abraham's covenant identity is correct, then "it would be a

matter of course" for $\mathrm{C}$, the test command $\mathrm{d}^{99}$ to require or evoke concrete, observable

${ }^{95}$ God calling his servant/friend by name and the human responding with hinneni is not unusual. What is unusual is that with Moses (Exod 3:4), Jacob (Gen 31:11), Samuel (1 Sam 3:4), and Isaiah (Isa 6:8), God called them by their birth names (even after he had given Jacob a covenant name-Gen 46:2). In the Aqedah, God called the testee by his covenant name Abraham, not his birth name Abram.

96 "Abduction is the process of forming an explanatory hypothesis. It is the only logical operation that introduces any new idea; for induction does nothing but determine a value, and deduction merely evolves the necessary consequences of a pure hypothesis." C. S. Pierce, Collected Papers of Charles Sanders Pierce, eds. Charles Hartshorne and Paul Weiss (Cambridge, MA: Harvard University Press, 1974), 106. Hermeneutically, when abductive reasoning excavates a possible purpose for a text which is confirmed by its explanatory power for the underlying logic and minute details of the text, fuller understanding has been gained. "We can understand a text only when we have understood the question to which it is an answer. But this question can be derived solely from the text and accordingly the appropriateness of the reply is the methodological presupposition for the reconstruction of the question, any criticism of this reply from some other quarter is pure shadow boxing. ... This is, in fact, an axiom of all hermeneutics; we described it above as "fore-conception of completeness. . . For we have seen that to question is to lay open, to place in the open." Gadamer, Truth and Method, 363, 375-376.

97 "Thus the principle rule of abduction is that "its conclusion should be such that definite consequences can be plentifully deduced from it of a kind which can be checked by observation." Arthur W. Burks, "Pierce's Theory of Abduction," Philosophy of Science 13, no. 4 (October 1946): 306.

${ }^{98}$ Pierce, Collected Papers, 117.

${ }^{99}$ The design of the test command is directly controlled by the tester and the test purpose. The testee may or may not align with the test purpose for they retain the freedom to respond to the test any way 
actions from what Abraham had internalized and integrated from the seven covenant

lessons. Since the Aqedah was a performance ${ }^{100}$ test, the integrated maturity of

Abraham's covenant character will be revealed by his response.

But first let us back up, what concrete observable actions could be expected from internalization of the previous seven epiphanies? The covenant epiphanies taught/trained Abraham through (1) Gen 12:1-3: to follow divine directions to an unknown destination by trusting God's vision of him as the father of a chosen nation, to believe he was protected by God to bless the world, (2) Gen 12:7: to offer sacrifice to the God that appeared and promised his offspring the land of Canaan, (3) Gen 13:14-17: to lift up his eyes and walk the land in possessive faith believing his offspring would be like the dust of the earth, ${ }^{101}$ (4) Gen 15: to see stars as indicative of progeny numbers and expect God to preserve the covenant at the cost of His own life, (5) Gen 17: to accept circumcism and his covenant name Abraham, believing that Isaac would bear the covenant line, (6) Gen 18: to believe Isaac would be born to Sarah and intercede with God for the innocent on

they wish. In fact, if the testee doesn't realize it is a test, their test response may be more authentic and uncontrived, therefore more revelatory of their true condition.

${ }^{100}$ Dr. Vadim Dementyev brought to my attention that the etymology of the English term performance comes from the French parfournir: par "through to completion" and fournir "furnish, provide." Oxford Dictionary of English, s.v. "performance," ed. Angus Stevenson, $3^{\text {rd }}$ ed. This concept of bringing something to completion suggests an intrinsically formative component to a performance test such as Abraham's test. Vadim Dementyev's own work highlights the performance aspect of homiletics in relation to the Trinity. Vadim Dementyev, "For the Sake of Beauty: Proposing a Homiletic of Trinitarian Performance" (PhD dissertation, Fuller Theological Seminary, 2019).

101 "One can also point to the command to Abraham to lift his eyes in 22:3 and 22:13 who [sic] might be reminiscent of the same wording in Genesis 13:14." K. Schmid, “Abraham's Sacrifice: Gerhard von Rad's Interpretation of Gen 22," Interpretation 62, no. 3 (2008): 268-276. 
the basis of divine mercy and justice, and (7) Gen 21:12-13: to not withhold his son from trusting God fully for his future.

As it happened, the Aqedah test design (Gen 22:1-2) started by calling his name, Abraham, which he confirmed (Lesson 5. Acknowledged his Covenant name) then God posed a covenant crisis through a sacrificial threat to Isaac's life. Physically, this required him to head out in faith to an ambiguous location (Lesson 1. Follow the divine call to an unknown destination), prepare and offer a burnt offering to God at the end of the trip (Lesson 2. Sacrifice to YHWH), to lift up his eyes and look (Lesson 3. Lift up eyes and look) ${ }^{102}$ while walking a three-day journey to Moriah (Lesson 3. Walk the land in faith of future possession), required overnight camping (Lesson 4. View the stars in faith that his descendants would be many) $)^{103}$ and wonder how God would risk his life to guarantee the covenant (Lesson 4. Told Isaac to trust that God would provide Himself, a lamb), and it necessitated Abraham transferring Isaac's complete trust to God (Lesson 7. Entrusted son to God's care) which Isaac did, for he was willing to be bound and set on the altar. What

\footnotetext{
102 "The patriarch, looking northward, saw the promised sign, a cloud of glory hovering over Mount Moriah, and he knew that the voice which had spoken to him was from heaven." Ellen G. White, Patriarchs and Prophets, (Mountain View, CA: Pacific Press Publishing Association, 1979), 151.

103 "Abraham looked up to the calm brightness of the unclouded heavens, and recalled the promise made nearly fifty years before, that his seed should be innumerable as the stars. If this promise was to be fulfilled through Isaac, how could he be put to death?" White, Patriarchs and Prophets, 148.
} 
Abraham was trained to do through most of the covenant lessons $(1,2,3,4,5,7)$ was required logistically by the test command.

Only one covenant lesson, the lesson of prophetic mediation (6. Prophetic intercession for the innocent based on divine justice and mercy) required a different approach. What method would be effective in eliciting authentic and heartfelt mediation (voluntary, not ordered)? As revealed by micro-hermeneutical analysis, the perlocutionary effect of the four appellations (your son, your only son, whom you love, Isaac) of the divine test command was in opposition to the locutionary content of the command to sacrifice Isaac. This was not the case with the previous divine order to banish Ishmael. The Principle of Humanity suggests that a father confronted with the loss of a second son to the same deity by verbal command would likely compare ${ }^{104}$ the two life-threatening commands. God's command to relinquish Ishmael offered two rational incentives to induce Abraham's compliance: to safeguard the covenant through Isaac as protected by Sarah and assurance that God himself would guarrantee Ishmael's survival and success as a great nation. No divine incentives or punitive measures for noncompliance are in the command for sacrificing Isaac.

In addition, three physical-emotive factors affect Abraham during his test. The divine source consistently remains out of sight (and at some distance in the heavens), the

\footnotetext{
${ }^{104}$ The hermeneutical Principle of Humanity would pose that any parent faced with notes from the same teacher about two different sons will naturally compare the differences in the teacher's perspective for each unique child. In this case, the life of each son is at stake, so the wording of God's commands was probably mulled on over and over during the three-day journey.
} 
repetitive appellations ${ }^{105}$ stoke paternal compassion, and the requirement necessitates

proximity to the victim with execution by Abraham's hand. ${ }^{106}$ These specific factors do not allow Abraham to evade direct personal accountability for Isaac's impending

demise. ${ }^{107}$

Could it be that the divine command to sacrifice Isaac by his own hand, nullifying

all of God's previous covenant promises, rhetorically delivered in a manner that

intensifies paternal compassion without any moral rationale to justify compliance, was a

test method to elicit from Abraham a response of covenant mediation? An authentic

intercession (voluntary and heartfelt) requires an authentic threat. The logistical design

of the test required enactment of six of the seven covenant lessons and the combination of

${ }^{105}$ These four appellations are the one consistent literary component that ties all three divine speeches in the Aqedah together, though they are in modified form in the second and third repetition.

${ }^{106}$ Sociologist Stanley Milgram's experiments in the 1960's demonstrated that increased spatial distance from the authority source and increased proximity with direct visual contact with the recipient of the "electric shocks" were the only modifications that decreased the percentage of humans who consistently obeyed authority figures to the point of being willing to inflict "fatal damage" to another human being in a simulated learning test. Without such modifications, the percentage of those willing to inflict fatal damage chillingly remained at 61-65\% regardless of socio-economic strata, education, or culture. Stanley Milgram, Obedience to Authority: An Experimental View (New York, NY: Harper Perennial, 2009).

107 The failed Nuremberg Defense plea was used by Nazi collaborators during the Nuremberg Trials of November 1945 to October 1946 to avoid culpability for killing others. It tried to absolve a subordinate from responsibility if they were merely carrying out what was commanded of them by their superior authority. The presiding judge, Justice Robert H. Jackson firmly believed that "individuals should be held accountable for what they had done. Mitigation of punishment might be considered, however, in cases where the moral choice was impossible." H. T. King Jr., "The Legacy of Nuremburg," Case Western Journal of International Law, Vol. 34. 335 (Fall 2002), 338. In Abraham's test from the highest authority in his life, no dire consequences for disobedience were specified and none had been imposed by God in their shared past. The Hebrew term na (please or now) in Abraham's test command is interpreted by Sarna to indicate "Abraham has absolute freedom of choice. Should he refuse he would not incur any guilt." Sarna, Genesis, 151. 
test rhetoric with the unjustified horrific sacrificial command begs for the covenant skill of prophetic intercession.

It appears the abductive hypothesis (A) that the test was a covenant-crisis challenge to elicit a comprehensive paternal covenantal response from Abraham demonstrates a robust predictive correspondence for the specific details of the test command (C) "as a matter of course." This logically linear alignment between the third speech (test answer key) and first speech (test design) of God in the Aqedah establishes internal validity for the covenant hypothesis. The four traditional ${ }^{108}$ hypotheses presented in this chapter's introduction (love, fear of God, morality, and faith in resurrection) are not as robust in requiring the specific details in the test command because all of them can be fully satisfied by commanding an offering of Isaac on an sacrificial altar right by Abraham's tent. ${ }^{109}$

In addition to the detailed design of the covenant test above, the customized scope of this particular test is ontologically comprehensive and customized to Abraham. It

${ }^{108}$ Three of the four traditional hypotheses for the Aqedah purpose are derived from the text either implicitly or explicitly, though on narrower grounds than the Covenant Hypothesis. One is imported from the New Testament but is congruent with the text. They are love (v. 2), fear of God (v. 12), morality (v. 2, 12), faith in resurrection (v. 5 and Heb 11:19).

${ }^{109}$ None of them require a walking journey, stars, looking up, intercession. If God's central purpose for the Aqedah test was not to test Abraham but mainly intended for the future - to reveal the future temple site and the operations of substitutionary sacrifice concretely, then the additional test command details could be seen to fulfill this purpose. The weakness with that ritual hypothesis for the sole purpose of the test is that a literalistically obedient pagan father could satisfy the test perfectly, for pagan fathers routinely traveled to high mountain places to worship (2 Kgs 17:10-11; Hos 4:13) and willingly sacrificed their firstborn children as burnt offerings. That Abraham's test actions appear identical to theirs poses a theological danger that can only be unpacked by understanding God's final speech and interpretation of Abraham's actions in the Aqedah correctly. 
encompasses the existential poles of Abraham's life. By posing a divine threat to Isaac's life, Abraham's faith was tested to its core belief in a promise-keeping God. At the opposite pole, by requiring Abraham's own hand to sacrifice his son, the test ironically put Abraham — who had a persistent fear of death — into the violent executioner's role. As the pragmatist Pierce once said, "what we think is to be interpreted in terms of what we are prepared to do." 110 The test design thus spans the complete vertical axis of Abraham's existential belief system, connecting his poles of metaphysical faith and concrete bodily fear. The superlative skill of the Tester is demonstrated in tailoring this test to Abraham like a customized glove for a hand. ${ }^{11}$

Now that the test command and the test assessment are aligned, how is the middle speech of the angel of YHWH (vv. 11-12) to be understood? ${ }^{112}$ Can the self-consistency implied by the Principle of Charity overcome the traditional assumption that God is rescinding or contradicting Himself? The Covenant Hypothesis anticipates the timing and content of this angelic interruption without imputing incongruity to God. The following

${ }^{110}$ Pierce as quoted by Arthur W. Burks, "Pierce's Theory of Abduction,” 303.

111 At the same time, this abductive hypothesis is an inference to the best explanation which, like all inductive inferential hypotheses, remains underdetermined. Peter Lipton, Inference to the Best Explanation (New York, NY: Routledge, 1991), 56. Thus, I remain open to better hypotheses in the future.

112 The hermeneutical Principle of Charity is used here in the attempt to interpret a seemingly contradictory verse in a coherent manner if logically possible. This is therefore a respectful endeavor to assume and uncover self-consistency in divine purpose. 
analysis will demonstrate how the covenant hypothesis interprets this speech in regard to (A) timing and (B) content.

A. Timing: Abraham's compliance to the test command had demonstrated all the lessons of the covenant except for one, the intercessory role of a prophet from covenant lesson six (Gen 18). With Isaac bound on the altar, when Abraham reached for the knife with the intent "to slaughter his son"- this was the exact moment where Abraham's test actions deviated from his previous covenant training. ${ }^{113}$ God had waited until the last possible moment, giving Abraham the maximum chance to remember or consider interceding for Isaac. But when Abraham, with full confidence that God was fully capable of resurrecting Isaac, ${ }^{114}$ reached toward Isaac with the butcher knife, the angel of YHWH suddenly broke through his faith-filled concentration to thwart him,

113 Abraham's choice of obedient violence demonstrated by taking up the knife instead of mediatorial intercession may be a harbinger, as are so many other parts of his life, of his descendants' proclivities for violence. God had promised Abraham, "To your offspring I will give this land" (Gen 12:7), "for all the land that you see I will give to you" (Gen 13:15), "to give you this land to possess" (Gen 15:7), "and I will give to you and your offspring after you the land of your sojournings" (Gen 17:8), but only after Abraham takes up the knife in the test does this divine gifting of land shift toward a method that promises victory in conflict. God substitutes the customary send-off blessing "your offspring shall possess the gates of his enemies" (Gen 22:18; 24:60) to correspond to the second covenant revelation (Gen 12:7). At the same time, this conflict blessing evokes and intimates' victory in the conflict between good and evil that was glimpsed in the promises of Gen 3:15.

${ }^{114}$ Heb 11:19. Resurrection hope necessitated killing Isaac because to raise a body to life, it must first be dead. Through this test, Abraham's faith was made complete: "You see that faith was active along with his works, and faith was completed by works" James 2:22. At what point in the test was his faith completed? 
"Abraham! Abraham! ... Do not lay your hand on the boy or do anything to him!" (v. 12).

B. Content: Boehm correctly points out that the first angelic speech "tends to over-explicate Abraham's obedience, which does not seem to require explanation at this point." 115 There is no question that Abraham's absolutely singular obedience and faith-filled resurrection hope are extraordinary and worthy of praise. Kierkegaard calls his fidelity to the letter of God's command the "guiding star that saves the anguished." ${ }^{116} \mathrm{Few}$ can believe in the resurrection as firmly as Abraham must have believed to be willing to kill his own son. Yet, reasoning a posteriori from the Aqedah text as it unfolds, it is clear that God didn't want Isaac killed even if the miracle of Isaac's death and resurrection would have exceeded the miracle of supplying an animal in a bush and provided a more exact typology for the death and resurrection of the Messiah. We must keep in mind that there is no specific praise in the text for

${ }^{115}$ Boehm, The Binding of Isaac, 29.

${ }^{116}$ Kierkegaard, Fear and Trembling, 20. 
Abraham's willingness to kill, ${ }^{117}$ even though his willingness to do so is often taken by less careful readers as the point of the story. ${ }^{118}$

Then why is the angelic interruption so repetitive and prolonged? Because it must accomplish a sensitive and sophisticated agenda, to forbid the intent while praising the motive behind it. ${ }^{119}$ The three parts ${ }^{120}$ of the speech are: 1) prohibition—Abraham's literalistic compliance and intention to harm Isaac by offering him up as a sacrifice is forbidden - Do not lay your hand on the boy or do anything to him, 2) affirmationAbraham's Fear of God is divinely acknowledged in the present-for now I know that you are God fearing, and 3) nuanced commendation-Abraham's paternal release of Isaac to God fulfils half of God's appellations for his relationship to Isaac—Seeing you

${ }^{117}$ On a tragic note, wrong Aqedah theology may cause psychic scars. The Aqedah may have been deeply imbedded in the suspicious subconscious of the Israelites slaves for they kept regressing to a worry about Moses' hidden motives to kill them (Exod 14:11-12, 16:3, Num 20:4) because Moses had framed his request to Pharaoh as a three-day journey into the wilderness to offer sacrifices (Exod 3:18; 5:3; 8:27). The motif of Moses' formal request may have summoned their collective memory of the Aqedah.

${ }^{118}$ The New Testament exegesis of the Aqedah by Jesus counters this focus on willingness to kill being the moral point of the Aqedah. "If you were Abraham's children you would be doing the works Abraham did, but now you seek to kill Me, a Man who has told you the truth which I heard from God. This is not what Abraham did" (John 8:39-40). Jesus clearly de-emphasizes Abraham's willingness to kill (though it is obvious in Gen 22:10 and is highlighted in traditional interpretations of the Aqedah) and spotlights the critical moral point that Abraham abstained from carrying out his intention because he listened to God's correction. Jesus condemns his opponents' intention to kill because they will not relinquish it and recognize the voice of truth from God through Jesus. Jesus' words, "Truly, truly, I say to you, before Abraham was, I am" (John 8:58), identifies himself as the divine Tester that gave the test command and was present at that event.

119 This is exactly what God did previously for Abimelech in a dream (Gen 20). He affirmed the innocent motives of the agent while adamantly prohibiting his intended action.

${ }^{120}$ When the angelic message of vv. 11-12 is read as the ending and final assessment of the test, one of its three parts is usually interpreted as the purpose of the Aqedah: (1) Prohibition of human sacrifice, (2) God needed to know if Abraham was God-fearing, and (3) God requires obedient relinquishment of anything (or everything) at His command. 
have not withheld your son, your only son [missing: whom you love, Isaac] from Me.

Each of the three parts will now be unpacked further.

1) Prohibition: Do the prohibitions reverse God's injunction to sacrifice Isaac because Abraham's obedience had already been proven by reaching toward Isaac with the knife? If analyzed carefully, the angelic prohibitions are not a direct reversal or retraction of the test command, as the potential phrase "do not offer him up as a burnt offering" would certainly be. Only the direct method for fulfilling the sacrifice of Isaac has been blocked by prohibiting Abraham's hand movement and intent to kill the lad. To be precise, the test command for Isaac's sacrifice still stands.

But if this true, how can Isaac be offered up as a burnt offering without being touched or without Abraham doing anything to him? It certainly seems impossible. But if the abductive covenant hypothesis is correct that Abraham is being set up to demonstrate the covenant lessons in his test response, covenant details not yet actualized by Abraham may offer an option. The yet unactualized covenant remnants are: Abraham intercedes with God (6. Gen 18:23-33), God appears at the altar site (2. Gen 12:7) and God in symbolic form takes on death to guarantee the covenant (4. Gen 15:17).

The perfect fit of these three unrealized aspects of the covenant experiences to the eventual test solution of the Aqedah demonstrates the generative power ${ }^{121}$ of

\footnotetext{
${ }^{121}$ The generative power of a research program of theories refers to its direct implications which can be validated. Imre Lakatos, "Falsification and the Methodology of Scientific Research Programes" in
} 
the Covenant Hypothesis in unlocking the test. Had Abraham prophetically interceded based on God's righteousness instead of taking up the knife, then looked around afterward for any sign that his prayer had been heard, the ram was just behind him and could have been discovered easily (as it certainly was) to fulfill God's test command for the sacrifice of Isaac indirectly, as Isaac's divinely-provided substitute and representative.

2) Affirmation: The central divine affirmation is "Now I know that you fear God." God reveals there is a temporal component to divine omniscience. Unlike ourselves who are passive knowers - either we know something or we don't, we cannot 'not know' once we are informed because we cannot control our knowledge precisely — God may be able to exercise exact control over the degrees, modes and methods ${ }^{122}$ of His omniscience in parallel fashion to His precise self-control over His own omnipotence. In the Aqedah, as invited by Abraham's hinneni, God's words reveal He is presently experiencing afresh the

Criticism and the Growth of Knowledge (Cambridge, UK: Cambridge University Press, 1970), 91-196.

${ }^{122}$ This is too large a concept to adequately address here and will be discussed in the macrohermeneutic chapter 5 that follows, in the section on Divine Hermeneutics. For now, consider that if human knowledge in human life-experience can be factual, relational, intuitive, inferential, emotional, practical, evaluative, forensic, contextual, imaginative, and creative, then by inference, since man is made in the image of God (Gen 1:17), God's scope of knowledge cannot be more reductive than man's, i.e. limited to cognitive propositions. God's omniscience must, by inference, include unlimited access to unlimited kinds and methods of knowledge while controlled by God's omnipotence over his own omni-abilities. In the Aqedah, "now I know" may indicate an existing, partial, self-restraint of one type of divine omniscience (perhaps relational-emotive) that has just been lifted by God in response to Abraham's actions, allowing a deeper saturation of divine experiential knowledge about Abraham in relational response to Abraham's free choice of responding to the test as he did. 
divine knowledge (yada — complete, intellectual, relational, intimate knowledge) of Abraham as one that fears God.

What drives Abraham's covenant identity? God-fearing faith. As Moses explained to the Israelites at another mountain, the fear of God embedded by God—through testing — keeps one from sinning: "Moses said to the people, 'Do not fear, for God has come to test you, that the fear of him may be before you, that you may not sin."' ${ }^{123}$ Abraham proved his fear of God was intact by remaining highly responsive to God up to the last second by not killing Isaac, allowing God to hold him back. At one time, Abraham had said in Gen 20:11, "I thought, 'There is no fear of God at all in this place." Yet, in that event it was the pure-hearted God-fearing Abimelech with clean hands who also allowed God hold him back ${ }^{124}$ from sin and showed even more concern than Abraham to avoid sin, "What have you done to us? And how have I sinned against you, that you have brought on me and my kingdom a great sin?"'125 If the current Aqedah commendation is heard against the background of Abraham's covenant journey,

123 Exod 20:20. But the terrified Israelites begged Moses to be a conduit between them and God to avoid direct address by God's voice. Their subsequent idolatry at the foot of the mountain proved the fear of God had not become part of them deeply enough. Meanwhile as their intercessor, Moses loyally opposed God's expressed intent to destroy them, pleading for God to remember the oath he made long ago on a mountain in Moriah (Aqedah), "Remember Abraham, Isaac, and Israel, your servants, to whom you swore by your own self, and said to them, 'I will multiply your offspring as the stars of heaven, and all this land that I have promised I will give to your offspring, and they shall inherit it forever." Exod 32:13. God relented.

\footnotetext{
${ }^{124}$ Gen 20:5-6.

${ }^{125}$ Gen 20:9.
} 
God is praising Abraham for catching up to Abimelech's level of God-fearing moral sensitivity and responsiveness. But was the fear of God the sole purpose of the Aqedah? Richard Middleton astutely points out, "This statement describes what was discovered through the testing, but it is a logical fallacy to infer that this was the purpose of the test-especially if we have reason to believe otherwise." ${ }^{126}$ So, if the angel's interruption of vv. 11-12 does not rescind or end the test but is an affirmative correction, wouldn't an ideal Tester hint toward the preferred response? ${ }^{127}$ Yes, and the hint is right in the center of the angelic speech. The angelic speech is couched in two familiar motifs: present divine knowledge ${ }^{128}$ (Now I know) and Fear of God ${ }^{129}$ (you fear God). These motifs thematically and

\footnotetext{
${ }^{126}$ Richard Middleton continues with an example: "A professor may say to a student after the test, 'Now I know that you are a "C" student.' But that doesn't mean that this was the purpose of the test. The professor was hoping the student would put out some effort and get an A." Richard Middleton, "Unbinding the Aqedah from the Straightjacket of Tradition: An Inner-Biblical Interpretation of Abraham's Test in Genesis 22," in upcoming book Reframing Lament, eds Matthew Anstey, Jeanette Mathews, and Peter Lockwood. First presented (under the title "How Abraham Lost his Son") as the Zenas Gerig Memorial Lecture at Jamaica Theological Seminary at Kingston, Jamaica, September 2012. Middleton believes Abraham's test was whether he could differentiate the character of his particular God from other gods. I wholeheartedly agree, it was their seven encounters that delineate the character of YHWH and what kind of obedience is desired by Him. The Fear of God is one of the goals of the Aqedah test, for faith, love, loyalty, obedience, hope and morality are all part of the covenant.

${ }^{127}$ The Principle of Humanity intuits what a benevolent tester who wants the testee to succeed, would do. The tester would correct a testee's mistake and pedagogically hint toward the right answer without giving it overtly.

128 "Now I know" is sometimes explained as directed to the reader and Abraham instead of God. Origen "says that the adverb is added in verse 12 for our sake to highlight that Abraham has clearly passed the test. He adds too that 'now' there is also certainty in Abraham's inner heart; he knows for sure that he is fully obedient to his God, regardless of the command." Carey Ellen Walsh, "Christian Theological Interpretation," 60. Yet, the words are self-referential to the speaker- the angel of YHWH.

${ }^{129}$ Since Jacob refers to YHWH as the Fear of Isaac (Gen 31:42) and the Aqedah is the only biblical narrative where Isaac and the term occurs, the implication is that Isaac could overhear the angelic messages. This may be why God is characteristically very gracious and indirect in correcting Abraham, especially in front of his bound son. God's glowing epitaphs to Isaac (Gen 26:5) and Solomon (1 Kgs 3:14)
} 
linguistically link the Aqedah angelic re-direction to God's self-revelation of his

knowledge-based judgment in Genesis $18^{130}$ and Abraham's mention of the fear of

God in Genesis 20. ${ }^{131}$ Interestingly, what ties these chapters together is that in

regarding their fathers are likewise sterling and covers for their well-known lapses.

${ }^{130}$ Divine knowledge and seeing is pivotal in Genesis 18 . God reasons, based on his initial choice to engage in preferential knowledge of Abraham, "For I have known him, that he may command his children and his household after him to keep the way of the Lord by doing righteousness and justice, so that the Lord may bring to Abraham what he has promised him" (Gen 18:19). Then God decides to advance another step and include Abraham into his confidence. He shares His reason for the earthly visit, to confirm divine knowledge by seeing for Himself the condition of Sodom and Gomorrah: "Because the outcry against Sodom and Gomorrah is great and their sin is very grave, I will go down to see (! ו אֶ ר אֶ הhether they have done altogether according to the outcry that has come to me. And if not, I will know" (Genesis 18:20-21). This sharing of divine intent with Abraham places Abraham in the category of prophets who are given unique access to God's plans ("For the Lord God does nothing without revealing his secret to his servants the prophets" Amos 3:7). Abraham then rises to his prophetic privilege by interceding for Sodom and Gomorrah (Gen 18:22-33).

${ }^{131}$ In the Abimelech debacle, knowing, withholding, seeing, and Fear of God are the corresponding terms used. Abraham is called a prophet by God and divinely set up to be an intercessor again (Gen 20:7). God knew Abimelech was morally innocent, "Yes I know you have done this in the integrity of your heart and it was I who kept you from sinning against me" (Gen 20:3-6). Abimelech berates Abraham the next day, asking him, "What did you see that you did this thing?" Abraham defended himself, "I did it because I thought, 'There is no Fear of God at all in this place, and they will kill me because of my wife." Clearly, Abraham was wrong, Abimelech did have a Fear of God as demonstrated by his clean hands and a pure heart, his strong sense of righteousness, his courage in confronting God and Abraham over the moral injustice of placing an innocent pawn like himself in peril of death, and his scrupulousness in avoiding sin. Yet God sets up Abraham to intercede, and he does so successfully for Abimelech (Gen 20:17).

Why is this story of Abimelech included in the Abrahamic cycle? Among other reasons, it may have been to give Abraham another chance at prophetic intercession. Though Abraham had interceded for Sodom and Gomorrah, he saw the next morning that they were destroyed (Gen 19:27-30). The reader knows that God had honored Abraham's intercession by saving Lot (Gen 19:29) but Abraham may not have known it since Lot retires to a cave and his daughters assume that they will never have a chance to marry (Gen 19:30-31). This suggests Lot chose not to rejoin society or return to Abraham's encampment.

Thus, Abraham could have assumed he had failed as a mediator and this would make him less likely to risk doing it again. This may be one reason why God specifically set him up in Gen 20 as a prophetic intercessor even when Abraham was morally unworthy as the facilitator of the sin, to encourage Abraham to intercede by granting him public success. 
both, the primary role of Abraham was identical: Abraham was set up by God to be a prophetic intercessor. ${ }^{132}$

3) Nuanced Commendation: The next phrase is sometimes understood to commend Abraham's willingness to relinquish or lose Isaac. However, I am convinced the phrase "you did not withhold ... from Me" commends Abraham for prioritizing full relational access between Isaac and God, allowing God to manage Isaac, but this phrase does not necessarily require the loss of Isaac's relation to Abraham. ${ }^{133}$ Joseph uses the exact same Hebrew term in Genesis 39:9 to Potipher's wife in explaining that Potiphar has not withheld anything from him except for his wife. Clearly, Potiphar didn't relinquish or renounce ownership of everything, for he demonstrates retention of ownership when he banishes Joseph as manager after hearing his wife's story. The term "not withold" means that Potiphar entrusted Joseph with access to managing all his things except for his wife. The precision of the divine phrase, "You have not witheld your son, your only son from Me," doesn't mean God is affirming Abraham's willingness to lose, relinquish, or kill Isaac through death but, accepting the contextually clarified use of the phrase, it is

\footnotetext{
${ }^{132}$ Interestingly, Sarah was present at both events as eyewitness (Gen 18 \& 20). Had Sarah been included in the Aqedah trip, it is possible that her input may have been invaluable as she knows Abraham was called a prophet and set up to intercede with God and in the case of Abimelech, that Abraham was successful in saving the doomed innocent.

${ }^{133}$ Three times in Genesis the meaning of "withhold" consistently targets the accessibility of the terminal relation between three entities: God withholds Abimelech from sinning against Himself (Gen 20:6); regarding Isaac, God commends Abraham for not withholding "your son, your only son" from $\mathrm{Me}$ (Gen 22:12), and Joseph says Potiphar has not withheld "anything from me." (Gen 39:9). Interestingly, Genesis 22:16 uses the phrase "you did not withhold your son, your only son" and drops the specification "from Me."
} 
God commending Abraham for his willingness to entrust Isaac to God, in other words allowing complete accessibility by letting God take control of Isaac's

future. The terminal bond between Isaac and God is the locus of action, without necessarily annihilating the original link between father and son (see Fig. 4.4).

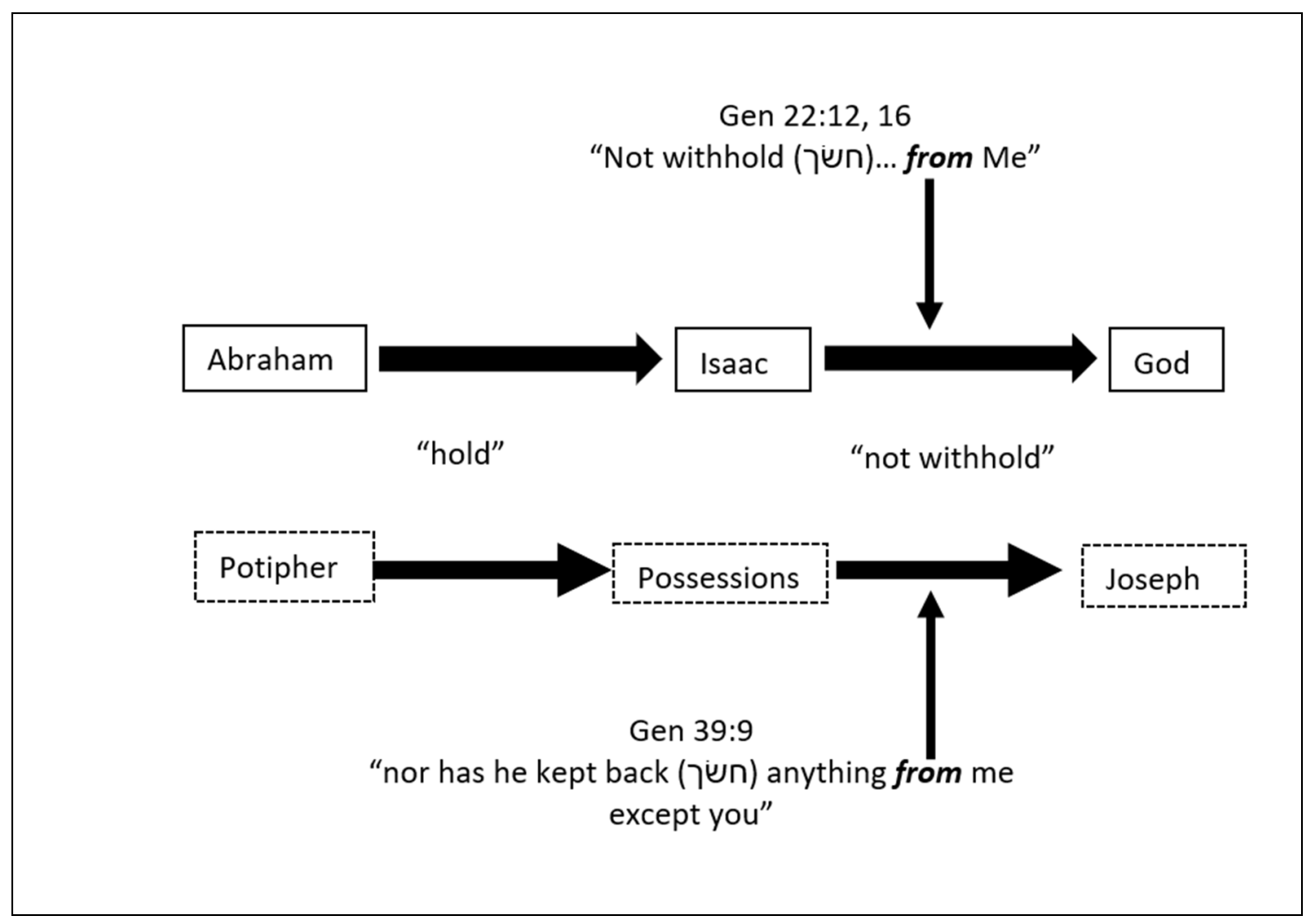

Fig 4.4 Locus of Relation targeted by the phrase: "not withhold."

Finally, Abraham's treatment of his son in the test is evaluated through the repetition of the test command appellations for Isaac: the first two are mentioned (your son, your only son) the last two are missing (whom you love, Isaac). Since Steinberg claims that the most valuable function of Hebrew repetition resides in 
illuminating "the inner life of the agents" and the "ethical value of their acts," 134 the shortened nomenclature reveals the divine ethical evaluation of Abraham's actions. Abraham's religiously motivated compliance in reaching toward Isaac with the knife to kill him treated Isaac as his son to give (biological and societal ownership), as his only son (entrusting his future to God as embodied in his precious son), but his test response did not embody the fullness of paternal love (whom you love) and a covenant-based regard for the unique covenant individual (Isaac). God's nuanced commendation suggests an alternative option existed and was missed. ${ }^{135}$

After his focus is freed by the angelic correction, the intially overlooked ram is visually discovered. An overlooked test solution deserves keen attention when discovered after a mistake ${ }^{136}$ to ponder the reason why it was initially missed. The ram's discovery

${ }^{134}$ Sternberg, Poetics of Biblical Narrative, 438.

${ }^{135}$ This may be why one thematic parallel with the preceding chapter remains unrealized in comparing the trials of the two sons of Abraham. The actualization of Ishmael's name, God hears, marked the turning point of his desert ordeal: "And God heard the voice of the boy, and the angel of God called to Hagar from heaven and said to her, "What troubles you, Hagar? Fear not, for God has heard the voice of the boy where he is" (Gen 21:17). Had Abraham mediated for Isaac as he had been trained to do on two different occasions (Gen 18 and 20), lifted his eyes and discovered the ram in the thicket, that might have converted their anguished tension into the joy-filled laughter of grateful relief at God's antecedent provision for their emergency. Isaac's pinnacle redemption could have been marked by the actualization of his name, eruptive father and son laughter.

${ }^{136}$ I do not believe Abraham's hope of resurrection is a wrong or sinful mistake, I believe it is an interesting mistake. It is an ethical mistake because it directly necessitated a willingness to kill Isaac, which was thwarted by the angel of YHWH. But it remains an interesting mistake because it forged a new channel of faith-derived hope from his past experience, fulfilling God's assertion that nothing is too hard for the Lord (Gen 18:13) and his grasp of the certainty of resurrection may have been the antidote God knew Abraham needed to heal his dysfunctional phobia of being killed. However, the cautionary aspect of this antidote is that once Abraham fixated on the resurrection as the test solution, he felt no need to look for another or better answer to his dilemma, so he stopped looking for the substitute animal. 
holds several surprising details. Directionally, it was positioned behind him. Temporally, it was provided prior this arrival, proof of antecedent divine grace and foreknowledge.

But the biggest surprise is that the test solution was not a young lamb but a mature ram.

Does this detail matter? The ram is the father relative to a lamb. Even if seh (v. 7-

8) is translated more literally as sheep or goat, the provided answer of the ram with horns indicates this was certainly a mature male sheep. ${ }^{137}$ Significantly, in this event, Isaac's two fathers are interacting through a test. This is a test between fathers. Abraham is the biological father of Isaac who has contributed one cell but God is clearly the co-paternal birth agent (Gen 21:1-2) of Isaac, the defender of Isaac's covenant inheritance (Gen 17:19-21;21:12), the protector of Isaac's future (Gen 21:22-24), and now the redeemer of Isaac's life by providing Himself through the representative animal to take the place of Isaac. In a sense, God is the superlative father of Isaac who backs up Abraham if Abraham falters in fulfilling his God-given paternal role. When the prophet Isaiah voices a lament of the oppressed that evokes Isaac's plight, Isaiah posits YHWH in this role of substitute superlative Father: "Look down from heaven and see, from Your holy and beautiful habitation. Where are your zeal and your might? The stirring of your inner parts

\footnotetext{
${ }^{137}$ Within two chapters the narrator has been unusually specific on sheep identity: ewes for the ownership of the well (Gen 21:28-30), a lamb or sheep in the conversation between Abraham and Isaac (Gen 22:7-8), a mature ram held by its horns in the thicket (Gen 22:13). Had a lamb been found in the thicket, the intertextual resonances between the Lamb of God taking the place of the designated lamb, Isaac, would have been aesthetically satisfying to a Christian reader. But it was specifically a ram that was waiting. Even more, it was held in place by his horns (about 3 years old). This ram image suggests theological links to: the three year old ram in the covenant ritual (Gen 15:9) that God passed through, the sole ram burnt offering on the Day of Atonement (Lev 16:3), the ram of burnt offering and the ram of ordination in the installation of Aaron and his son as priests (Lev 8:18,22), and the messianic prophecy that envisions the coming savior as our "everlasting Father" (Isa 9:6) for the ram is the father-figure among sheep.
} 
and your compassion are held back from me. For You are our Father, though Abraham does not know us and Israel does not acknowledge us. You, O LORD, are our Father; our Redeemer from of old is Your name" (Isa 63:15-16). In the Aqedah sacrifice, the substitution of the father ram ${ }^{138}$ taking the place of the lamb points typologically to the role of Christ ${ }^{139}$ who, as our "Everlasting Father" 140 takes upon Himself our sacrifice as the provided "lamb of God."141

How does the test solution of the ram relate to the center of the chiastic structure? "Hinneni, beni" (here I am, my son) is the central point from which the Aqedah is composed centrifugally. It is the response of a responsive compassionate father who offers himself to his son. Flanked on both sides by Abraham's hinneni to God, this center embodies the essence of Abraham's covenant relationship. "The relationship of father and son that existed between Abraham and Isaac was exactly the same relationship that existed between God and Abraham." ${ }^{142}$ The substitutionary ram represented Abraham's

138 "We can even say that the ram was a symbol of Christ, for to be held fast by the horns is like a crucifixion. So all this obscurely prefigures Christ." Augustine quoted by Walsh, "Christian Theological Interpretation," 59.

139 “'Luther draws a parallel with Christ's two natures here. Isaac stands as Christ's divine nature, which does not die, while in the ram 'here Christ, the Son of God, is prefigured, who like a mortal man died on the cross. Yet the divine nature did not die, the human nature being sacrificed in its place." Walsh, "Christian Theological Interpretation," 60.

140 "For to us a child is born, to us a son is given; and the government shall be upon his shoulder, and his name shall be called Wonderful Counselor, Mighty God, Everlasting Father, Prince of Peace." Isaiah 9:6. [italics added]

${ }^{141}$ John 1:29. Jesus is both Son (lamb) of God and Everlasting Father (ram) to us.

${ }^{142}$ Hard Sayings of the Bible, Walter C. Kaiser Jr., Peter H. Davids, F. F. Bruce, Manfred T. Brauch (Downers Grove, IL: InterVarsity Press, 1996), 125. God called Abraham to depart from his father's household and filled that void with Himself in an ideal paternal relationship to Abraham by providing a new vision that exceeded his wildest dreams (Gen 12:1-3, 7; 13:14-17), met with him multiple 
redemptive God, the ideal father figure. The eternally compassionate, open and intimate presence of Abraham's God was conveyed through Abraham's response to Isaac “Here I am, my son," and is relayed to Abraham's descendants through the Messianic name Emmanuel, "God with us"143 who, as our everlasting Father, became our substitute sacrifice. The center of the Aqedah does not hold a paradoxical vacuum, or a question without an answer, or a metaphysical mystery, but the reassuring response of a human father embodying to his son the compassionate concern of his heavenly Father, later fulfilled by the ram that gave up its life for the endangered son. Abraham protectively deferred $^{144}$ full honesty by giving Isaac a God-centered, hope-filled but seemingly evasive answer to his question (God will provide Himself the lamb for a burnt offering, my son),

times to mature him into a visionary father of faith. When there was an option to share bad news, God chose to, twice (Gen 15:13-16; 18:18). When Abraham doubted whether he would have heirs, God brought him out to count the stars and reassured him (Gen 15:5). When Abraham pleaded for something more tangible, God self-imprecated Himself by passing through cut animals to covenant with Abraham (Gen 15: 18-21) and directly addressed Abraham's deepest fears about dying (Gen 15:15). God modeled covenant fatherhood to Abraham in training.

${ }^{143}$ Isa 7:14; Matt 1:22-23.

${ }^{144}$ Abraham has a habit of keeping crucial details to himself. After he was told by God that he would have a son in about a year (Gen 17), God visited him in person (Gen 18). Sarah's words imply she didn't know about God's promise and hadn't been intimate with Abraham yet, for Sarah laughed to herself after God promised a son in a year, saying, "After I am worn out and my lord is old, shall I have pleasure?" (Gen 18:12). Later, Isaac repeats Abraham's ruse in passing off his wife as his sister in the same town of Gerar (Gen 26:6-14). Not only does this violate Abraham's and Abimelech's treaty to not to deal falsely with each other or with each other's descendants (Gen 21:23), it suggests that Isaac may not have known about the history of his father's very public embarrassment in that same city. Most scholars believe that Abraham didn't tell Sarah about the test command when he took Isaac to Moriah. Like father, like son, Isaac also tried to hide from his wife his plans to bless Esau (Gen 27). 
which is not the center of the Aqedah as indicated by its offset position ${ }^{145}$ in the chiastic structure, but God also redeemed it as fulfilled prophecy.

But if the ram is the test solution of the Aqedah, why does God not verbally command or indicate the ram sacrifice? Perhaps because the divine voice exceeds explicit words; miraculous circumstances are included as God's communications. Abraham's lifting up of his eyes that sees the ram reveals he has regained his previous ${ }^{146}$ capacity to recognize God's providence with faith-attuned senses. His claim that the ram was divinely provided proves his prophetic insight is intact, despite his lapse of prophetic intercession. Abraham's substitution of the ram "instead of his son"(v.13) indicates the angel did not abrogate the original test command for Isaac's sacrifice, for the ram fulfills the command in Isaac's place. The emic ${ }^{147}$ meaning for the Aqedah test is expressed in Abraham's naming of the site "the Lord will provide." Worship, for Abraham, focuses on

145 "Here I am, my son” is the exact center of the Aqedah literary chiastic structure, not Abraham's answer, "God will provide Himself a lamb, my son." Had Abraham answered Isaac's question with his only authentic answer in the Aqedah by repeating "Here I am, my son," Abraham's willingness to reflect the self-sacrificial role of God (Genesis 15) in guaranteeing the covenant with his life might have become part of an intercessory plea at the altar site. But the ram representing God Himself would still remain the ultimate and final solution. In one hypothetically ideal scenario-both Abraham and God could have demonstrated paternal compassion at the cost of their lives, with Abraham's perennial fear of death overridden by his love of Isaac, God, and the covenant. This possibility would have set up Abraham to be a fuller type for Christ, superseded by God's provided ram.

146 Previously, (v. 4) he lifted his eyes and saw the designated place from far away. His visually directed recognition is either confirmation of a nondocumented verbal communication or taken by Abraham to be synonymous to the voice of God.

147 The term emic has come to stand for the internal language and meanings of a defined culture as expressed by a member of that culture and therefore is considered a more authentic expression than an etic description with conjectures from an outside observer who cannot hope to capture comprehensively all the nuances of meaning. See James Lett, "Emics and Etics: Notes on the Epistemology of Anthropology" in Emics and Etics: The Insider/Outsider Debate, eds. Thomas N. Headland, Kenneth L. Pike and Marvin Harris (Newbury Park, CA: Sage, 1990), 127-142. 
divine eschatological grace, not in his own obedient performance. Lastly, because

Abraham's undirected but completed ram sacrifice is included in "because you have done this," God's final divine commendation "you have obeyed My voice" includes

Abraham's obedience to both God's auditory and non-auditory voice. ${ }^{148}$

In retrospect, throughout the covenant journey God has transformed Abram into

Abraham (Gen 12:1-3, 15, 17, 22:1-2), corrected Abraham when he needed it (Gen 15:4;

17:19- 20, Gen 22:12), rescued his family members when they needed it (Gen 12:17;

$16: 7 ; 19: 29 ; 20: 6-7 ; 21: 17,22: 13$ ), protected his reputation (Gen 12:16-17; 15:19; 20:7)

and blessed him (Gen 12:2-3, 7; 13:14-17; 15:5, 7, 18-19; 17). God's actions in the

Aqedah (calling [v. 1], correcting and protecting [vv. 11-12], rescuing [v. 13], and

blessing [vv. 15-18]) is a condensed recap of what He has been providing until now for

Abraham. The Aqedah is a cumulative reprise of Abraham's learning and God's

seeing/providing for Abraham. With a Tester like Abraham's God, we need not fear His testing.

The hermeneutical sin in interpreting the Aqedah lies in privileging Abraham's words and actions over God's words and actions in the narrative. The text-given paradigm of a test and its own literary structure must direct and help the interpreter weigh

${ }^{148}$ As a Christian I believe that Holy Spirit works through every aspect of this narrative, but the ram sacrifice is where I recognize retrospectively the Holy Spirit working in and through Abraham in the Aqedah. It is the Holy Spirit who imbues the believer with spiritual insight to interpret circumstances in harmony with the Word of God, guides them in faithful deeds of love that go beyond explicit divine commands and helps the believer perceive events as foretokens of the final fulfillment of God's promises. Jesus' exegesis of the Aqedah event discloses the ensuing exuberance in Abraham's joyful understanding of the future fulfillment of his own test, "Your father Abraham rejoiced that he would see my day. He saw it and was glad" (John 8:56). 
the parts correctly. ${ }^{149}$ It is only by hearing all of God's words in the Aqedah even more sensitively and seriously that the beauty of a cogent (covenant identity) yet comprehensive (integrated covenant) test of Abraham becomes clear. The theo-centric viewpoint of the Aqedah is that God imposed a covenant-crisis challenge to elicit an integrated covenant response from father Abraham.

Alternative thesis: Anthropocentric viewpoint

Turning from the omniscient Tester, we now examine the Aqedah from the complimentary anthropocentric viewpoint of the puzzled yet trusting testee. Von Rad is right that the "twofold viewpoint for the story, which is about to unfold (one sees it through Abraham's eyes and at the same time from a high level), unmasks the extraordinary narrator." ${ }^{150}$ In contrast to the theocentric thesis of the Aqedah as a divine test of covenant crisis to be solved by the covenant, most interpretations of Aqedah literature interpret it as a divine test or trial to be endured by literal compliance based on Abraham's actual actions which earn him God's praise. Traditional interpretations usually understand the Aqedah as a radically disjunctive event requiring the abdication of

\footnotetext{
${ }^{149}$ Without the text functioning as a norm for understanding, unchecked presuppositions slip into Aqedah interpretations unnoticed, for instance, we can now see that: test passing does not require a perfect test score, the testee is not a reliable norm for the original purpose of the test, not all tests of faith are compliance or endurance tests, human suffering is an unreliable value currency for sacrifice, dramatic moral paradox is not holier than solvable moral challenge, the ultimate worship of God is not the same as the ultimate worship of Baal or Moloch, teleological suspension of the ethical is not inevitable in the Aqedah, resurrection hope never justifies ritual human slaughter, preferred typology doesn't refute accurate interpretation, nihilism is not the highest pinnacle of morality, pedagogy does not warrant abuse of others, and this test might turn out to be a measurement assay not a pass/fail audition based on human response.
}

${ }^{150}$ Von Rad, Genesis, 239. 
the covenant at God's command. Even as he believed God would give Isaac back after his dies, this test required Abraham to relinquish his future through the ancient ritual of human sacrifice.

The divine demand for human sacrifice in the Aqedah confronts the reader's modern sensibilities in front of the text as unbearably horrific. As Levenson has expertly outlined, the world of biblical meaning behind the text included sporadic familiarity with human sacrifice and the sacrifice of a firstborn innocent fits the perfect firstfruit offering motif. ${ }^{151}$ Westermann writes, "the history of religions attests human sacrifice in a number of places, as well as among Israel's neighbors, the Phoenicians, the Ammonites, the Moabites (2 Kings 3:21), in Egypt and Canaan." ${ }^{152}$ When God addressed Abraham with the command to sacrifice Isaac (Gen 22:1-2), Abraham may have been familiar with this form of worship ${ }^{153}$ though it must not be forgotten that he heard this difficult command coming from his trusted God, to whom he belonged and who had sustained him through

\footnotetext{
${ }^{151}$ Levenson, The Death and Resurrection of the Beloved Son, 3-17. Plaut suggests Abraham might have considered the command legitimate in the historical context of his times, this is why he didn't protest as over Sodom and Gomorrah. The Torah: A Modern Commentary, G. Plaut, ed. (New York, NY: UAHC Press, 1981) 149.

152 Westermann, Genesis 12-36, 357; Moberly, “The Earliest Commentary on the Akedah,” 305.

153 “Indeed, to modern eyes this may seem obvious: a father's readiness to sacrifice his beloved son presents an exceptional act of submission. To earlier readers, however, this was not quite as obvious. On the contrary, as I already said, stories of child sacrifice were frequently encountered in the Near East; there was nothing out of the ordinary in Abraham's readiness to sacrifice Isaac. . . . In the Near Eastern stories, the father is not only willing to slay his son but, unlike Abraham, eventually does so." Boehm, The Binding of Isaac, 15.
} 
the years. ${ }^{154}$ Though he was not told he was being tested, ${ }^{155}$ he immediately sets out to comply with the test command (Gen 22:3-10).

In the Aqedah there are four verbal clusters of Abraham's actions. Three of the verbal clusters demonstrate Abraham's radical compliance to the test command details

\footnotetext{
154 "This familiarity of shared history must be granted to Abraham in order to understand his willingness to accept the command." Westermann, Genesis 12-36, 356.
}

${ }^{155}$ Divine tests are found in the Bible and Abraham is depicted as experiencing such ordeals multiple times. "The idea of temptation, i.e., of a pedagogical test which God permits men to endure in order to probe their faith and faithfulness, is not really new in the patriarchal stores. The report about God's promise and conduct of Abraham from Mesopotamia (chs. 12.1 ff.; $15.1 \mathrm{ff}$.) contained a temptation motif. The outbreak of famine must also be understood as a test which Abraham did not pass (ch. 12.10 ff.). And finally, the visit of the three heavenly beings was a test for Abraham (see at ch. $18.1 \mathrm{ff}$.). What is here new, however, is the programmatic appearance of the idea of testing in the very first verse of the story as well as its destructive harshness." Von Rad, Genesis, 239.

Testing was a common theme in Israel's wilderness experience and either referred to obeying an expressed law of God and resisting the temptation to break that law (Exod 16:4) or being tested through a fearsome experience so that the fear of God would remain before them, to help keep them from sinning (Exod 20:20). Instilling the fear of God, compliance to His commands, faithfully trusting in His redemption are the expressed goals of corporate wilderness testing and has been applied to the Aqedah as relevant themes. However, two important differences distinguish the tests of Israel from the Aqedah: (1) the Aqedah is a final test of an individual entity at the end of a long covenant journey compared to a corporate entity initiating their covenant experience and (2) the Abraham's test command contradicts God's previous words, Israel's tests usually demanded alignment with God's previous words.

A closer analogy to the Aqedah as an individual test after a long collaborative history with God is God's test of Hezekiah with the envoys from Babylon. Hezekiah's one failing was pride and greed, evidenced by his accumulating riches "for himself." The test targeted that weakness. "And so in the matter of the envoys of the princes of Babylon, who had been sent to him to inquire about the sign that had been done in the land, God left him to himself, in order to test him and to know all that was in his heart." ( 2 Chron 32:31). Hezekiah fails his test (2 Kgs 20:12-19). Correspondingly, Abraham's one persistent failing was his fear of violent death at the hands of others, it is aptly ironic then, to put the knife into his hand and make him confront violent death through the imperiling of his beloved son.

The second aspect of testing an individual through contradictory divine commands have resulted in varied human responses as recorded in the Bible. Yet they are not routinely charged with disobedient sinning even if they respectfully decline to comply: (a) When God commands Ezekiel to cook over human dung, Ezekiel begs to not defile himself and God acquiesces and allows cow dung (Ezek 4:12-15 vs Deut 23:12-14 human dung is to be covered up, not seen by God who walks among you). However, the divine accommodation mitigated the intended lesson of exiles in extremis eating food that is defiled. (b) God commands Hosea to marry Gomer and remarry her after she has been with another man (Hos 1:2-3; 3:1-3 vs Lev 21:7 priests prohibited from marrying prostitutes or previous married women, Deut 24:1-4 a divorced woman, who remarries and divorces again cannot be taken back by former husband, it is called an abomination). Hosea complies, and God uses his marriage as an object lesson of God's faithfulness to unfaithful Israel. (c) A prophet commands another prophet to strike and harm him (1 Kgs 20:35-37 vs Exod 21:18-27 striking has consequences in a conflict context). The first one refuses. "Then he said to him, "Because you have not obeyed the voice of the Lord, behold, as soon as you have gone from me, a lion 
without deviation: preparation for journey (v. 3: rose, saddled, took, cut, arose, went), transfer (v. 6: took, laid, took), preparation for sacrifice (vv. 9-10: came, built, laid, bound, laid, took). They warrant God's affirmation, "Now I know that you fear God" (v. 12) $)^{156}$ and "you have obeyed my voice" (v. 18) because Abraham personally ${ }^{157}$ undertakes all the actions necessary leading up to the sacrifice of Isaac with unmistakable focus and unswerving resolve. ${ }^{158}$ However, the last and fourth verb cluster regarding the transfer of sacrifice to the ram (v. 13 went, took, offered) falls outside the scope of divine verbal commands. Nahum Sarna recognized this, "Substitution of the ram for Isaac is a spontaneous gesture on the part of Abraham, performed at his own initiative and not

shall strike you down." He is killed by a lion. The next candidate complies, and the wounded prophet carries out a mission to be an object lesson to Ahab from the Lord. (d) Jesus ignores a Syrophoenician woman and seemingly rejects her, referring to her as a dog (Matt 15:21-28; Mark 7:24-30 vs Matt 5:22 not to insult anyone or call them a fool or they will be subject to the fires of hell), she accepts the metaphor by persisting in claiming leftover crumbs from the Master of dogs. Jesus rewards her faith by granting her wish and praises her. (e) Peter is commanded to eat unclean animals three times in a vision (Acts 10-11 vs Lev 11; Deut 14). Peter consistently declines the command in vision, then is guided by the Holy Spirit through intuition to interpret the vision as a metaphor for accepting gentiles who had been previously been considered "unclean" by the Jews.

${ }^{156}$ The Fear of God "must not be considered as a special emotional reaction to the reality of God which is experienced as mysterium tremendum. That the Old Testament is familiar with such a thing cannot be disputed, but where the phrases 'fear of God' and 'fearing God' occur in the Old Testament, they refer not to a particular form of strong emotions but rather to their consequence, i.e., to obedience (Gen 20.11; 42.18; II Kings 4.1; Isa 11.2; Prov 1.7; Job 1.1, 8). It would be more correct to interpret the phrase 'fear of God simply as a term for obedience to the divine commands. But the Old Testament rarely uses this word predicatively. This passage, to be sure, and Job give exemplary proof of such obedient fear of God (Job 1.1, 8)." Von Rad, Genesis, 242.

${ }^{157}$ As noted by the micro-hermeneutical level of exegesis, all the verbs in these verb clusters are in the masculine singular with Abraham as their antecedent agent.

158 "He was on the way three days, and one already sees from that that his obedience was firm and not simply a brief effervescence." Von Rad, Genesis. 240. 
divinely ordained." 159 Yet, this last verb cluster is the most important of the group in the Aqedah because it matches and fulfills the test command verbs with went, took, offered (v. 2 take, go, offer). Linguistically, it signals exact obedience; objectively, it incorporates God's provided solution; narratively, it concludes Abraham's test performance.

In contrast to the transparency of Abraham's compliant actions, his speeches are ambiguous. Isaac hears all of them except for the initial test command. The only unambiguous answer in the Aqedah that Abraham gives is Hinneni (Here I am), his ready and open response to God and to his son that anchors the chiastic structure. But the rest are open to diverse interpretation. Abraham's first speech to his servants is bordered by two verbal clusters (prep and transfer) and preceded by Abraham's apperception of the mountain place. Abraham describes his mission as worship with assurances that they would both return. This conveys faith in God's promise that Isaac will return, but knowing Abraham's history of half-truths, one cannot exclude other motives for his words. ${ }^{160}$ Abraham's answer to Isaac's question conveys hope that God will intervene by providing Himself as the sheep for the burnt offering. ${ }^{161}$ But Abraham's answer allows for

159 Sarna, Genesis, 392.

160 "White lie, prophecy, hope, even disobedience, can surely coexist in the believer, especially in times of acute crisis. The enigmatic ambiguity of 'we shall return' perhaps gives an insight into the quite contrary ideas agitating Abraham's mind at this time ('I believe; help my unbelief,' Mark 9:24; cf. Matt 14:27-31)." Wenham, Genesis 16-50, 108.

161 Trusting in God's providence is how Calvin interprets the meaning of Abraham's speech: "This example is proposed for our imitation. Whenever the Lord gives a command, many things are perpetually occurring to enfeeble our purpose: means fail, we are destitute of counsel, all avenues seem closed. In such straits, the only remedy against despondency is to leave the event to God, in order that he may open a way for us when there is none. For as we act unjustly towards God, when we hope for nothing from him but 
at least two meanings, either that God will provide the animal for a burnt offering or less likely, that Isaac is the animal God has provided for the burnt offering. ${ }^{162}$ From his words it appears Abraham is struggling to work out how God's command to immolate Isaac as a burnt offering might be fulfilled without disobedience on his part and losing Isaac. This one and only conversation recorded between father and son is flanked on both sides by the inclusio- "So they went, both of them together."

The verb cluster of preparation for the burnt offering has most scholars assuming Isaac was told about his role and was compliant because he is bound first, then placed on top of the wood of the altar by Abraham. But no communication is divulged by the text. ${ }^{163}$ By the time Abraham's reaches for the knife "to slaughter his son" (v. 10) it is clear Abraham is no longer looking for (if he ever was) a substitute animal. The writer of Hebrews relays that Abraham reasoned God could resurrect Isaac (Heb 11:19). This faith-filled conviction propelled him to reach toward Isaac for the sacrificial slaughter,

what our senses can perceive, so we pay Him the highest honor, when, in affairs of perplexity, we nevertheless entirely acquiesce in his providence." John Calvin, Commentaries on The First Book of Moses, $1: 568$.

162 "The answer is ambiguous, but it contains a truth of which Abraham himself is not yet aware." Von Rad, Genesis, 241.

${ }^{163}$ Luther imagined a dialogue here: "The son was undoubtedly struck with amazement and in turn reminded his father of the promise: 'Consider, father, that I am the offspring to whom descendants, kings, peoples, etc., have been promised. God gave me to my mother Sarah through a great miracle. How, then, will it be possible for the promise to be fulfilled if I have been killed? Nevertheless, let us first confer about this matter and talk it over.' All of this should have been recorded here. I do not know why Moses omitted it." $L W 4,112-113$. Calvin, along with most theologians imagines Isaac "voluntarily surrendered himself." Calvin's answer to skeptics was, "Should any one object, that there was no necessity to bind one who willingly offered himself to death; I answer, that the holy man anticipated, in this way, a possible danger; lest anything might happen in the midst of the act to interrupt it." John Calvin, Commentary on Genesis, $1: 568$. 
for the son must die in order to be resurrected. Only then did the angel of YHWH suddenly counter his course of action.

In traditional interpretations the angelic prohibition officially ends the test at this point with his commendation of Abraham's motive. Westermann interprets the angel's message as "Now I know that Abraham is God-fearing; this has been shown by the fact that he has not withheld his only son from God. And so he has passed the test."164 Abraham's intent "to kill his son" counts for the deed, so he is regarded as obeying fully. ${ }^{165}$ Yet God's righteous morality is not to be impugned because Isaac was not physically sacrificed. ${ }^{166}$ Though by outward action there appears to be no difference between Abraham and religious fathers who were willing to sacrifice their children to worship Baal and Molech, on the inside, faith in God's resurrection for this lifetime is said to be the critical difference between the two kinds of fathers. But this focus on Abraham's faith in the resurrection as the clear religious difference between his faith and the faith of other pious but idolatrous fathers is not indisputable. Shalom Spiegel notes

${ }^{164}$ Westermann, Genesis 12-36, 361.

165 The concept that intent is morally equivalent to the deed is supported by Matt 5:27-28, "You have heard that it was said, 'You shall not commit adultery.' But I say to you that everyone who looks at a woman with lustful intent has already committed adultery with her in his heart." However, this idea is not exclusive to Christians. Nahum Sarna writes, "It is not important that the act was unfulfilled, for the value of the act may lie as much in the inward intention of the doer as in the final execution." Sarna, Genesis, 153. "The intent and willingness to offer Isaac is seen as equivalent to doing it. Abraham's inner act of responsiveness to God's command is the equivalent of an outward act in which Isaac was returned to God as a sacrifice." Hamilton, Genesis 18-50, 117.

166 This logic is not consistent. If Abraham's intent is accepted as morally equivalent to the deed to kill Isaac, then God's intent in the test command to require Abraham's intent to kill Isaac must also be taken as morally equivalent to the deed of killing Isaac. 
that resurrection was not a foreign concept to ancient religions and was indeed even routinely celebrated in ritualistic fashion in Canaan. ${ }^{167}$

Now, I want to be clear that Abraham's response in the Aqedah is to be commended for accurate literal obedience to the divine test command. His willingness to give up everything through the offering of Isaac opens new vistas for theological contemplation on the extreme limits of morality, ethics, faith and meaning. It is only after Abraham has gone to the limits of his endurance that the angelic encounter relieves him and Abraham discovers the divinely provided ram as the test solution and offers it instead of his son.

There is also more than one way to understand who the ram represents. It may represent God, Isaac or Abraham. Doukhan suggests God, the lamb and Isaac are represented: 'First, God Himself had been 'provided' as ('instead of') the lamb for the sacrifice (22:8), and thus implicitly 'instead' of the son. It is the ram, which is now substituted by God as the sacrifice 'instead of' the son." 168 Wenham equates the ram to Isaac, "In sacrifice the animal symbolically represented the offeror whose place it took. Here the ram replaces Isaac, so a full-grown ram, as opposed to a younger lamb, fittingly

\footnotetext{
${ }^{167}$ Spiegel, The Last Trial, 113. Baal himself was an ancient Near Eastern resurrection god and according to the Canaanite version, "Baal dies, a victim of deified Death (Mot), in the hot, dry summer; nature dies with him. But Death is, in turn, killed, Baal lives anew, and nature flourishes and luxuriates in response." Jon Levenson, Resurrection and the Restoration of Israel: The Ultimate Victory of the God of Life (New Haven, CT: Yale University Press, 2006), 215.

${ }^{168}$ Doukhan, Genesis, 286.
} 
takes his place." ${ }^{169}$ But since the test commanded Abraham to offer up Isaac's sacrifice, the ram could represent the offerer Abraham and at the same time substitute for Isaac as the victim. In the end, for Abraham the meaning of the Aqedah and worship does not rest on the symbolism of his human task, but on the divine source for the sacrifice. God will see/provide is what Abraham clearly re-affirms as the final meaning of the test.

God then re-establishes the covenant and promises blessings to Abraham and his seed ending with the affirmation, "You have obeyed my voice." Moberly explains how divine grace and obedience work together in the covenant.

A promise which was previously grounded solely in the will and purposes of Yahweh is transformed so that it is now grounded both in the will of Yahweh and in the obedience of Abraham (VT 38 [1988] 320). This is analogous to the assumptions underlying intercessory prayer. Here, too, faithful human response to God is taken up and incorporated within the purposes and activity of God. ${ }^{170}$

Abraham then returns home with his servants. The test is over, the covenant has been re-established because Abraham was willing to lose his son ${ }^{171}$ but Isaac was spared

\footnotetext{
169 Wenham, Genesis 16-50, 110.

${ }^{170}$ Moberly, "The Earliest Commentary on the Akedah," 320.

171 "Abraham has demonstrated his willingness to forfeit his posterity in obedience to God's will." Sarna, Genesis, 154.
} 
by the angel and Abraham's obedience and faith has been tested and proven to God's satisfaction. Thus ends a summary of the anthropocentric viewpoint on the Aqedah.

Synthesis: The final form of the Aqedah

The final form of the Aqedah blends the theocentric and anthropocentric viewpoints together so masterfully that few catch the discrepancy between God's will and Abraham's actions in the test. It is routinely presumed that Abraham's test response must be perfect due to God's commendations and the lack of censure. Yet theological tensions ${ }^{172}$ and awkward linguistic transitions ${ }^{173}$ persist in the final form of the text just below surface readings and continue to elicit new explanatory endeavors from discerning interpreters.

The application of the hermeneutical method to the Aqedah has unearthed a theocentric thesis of the Aqedah which sees the divine test as a covenant crisis designed to elicit a paternal covenant response from Abraham. The anthropocentric alternative thesis of Christian interpretations lauds Abraham's faith-filled literalistic compliance as buoyed by his resurrection hope based on Hebrews 11:19. ${ }^{174}$ Recognition of the interplay between the two viewpoints, divine and human, in the Aqedah provides the most

\footnotetext{
172 The main moral-ethical tension remains "Given the divine command to sacrifice Isaac ... disobedience cannot be regarded a 'better' alternative to obedience. There is no 'better alternative' for Abraham in this narrative, neither rationally nor ethically: killing one's son and disobeying a direct divine command are both unthinkable." Boehm, The Binding of Isaac, 3 .

${ }^{173}$ See Moberly, "The Earliest Commentary on the Akedah," 309-310.

${ }^{174}$ Overlapping the Christian emphasis on faith, Jewish anthropocentric interpretations follow the compass of overt compliance as voiced by God's final assessment of Abraham, "You obeyed my voice."
} 
coherent explanation for explaining the narrative and satisfying the two criteria of internal coherence and correspondence ${ }^{175}$ and the three heuristics of the Principle of Charity, of Humanity and Occam's Razor. The two viewpoints are depicted in Figure 4.5 below and together, they constitute the Covenant Hypothesis.

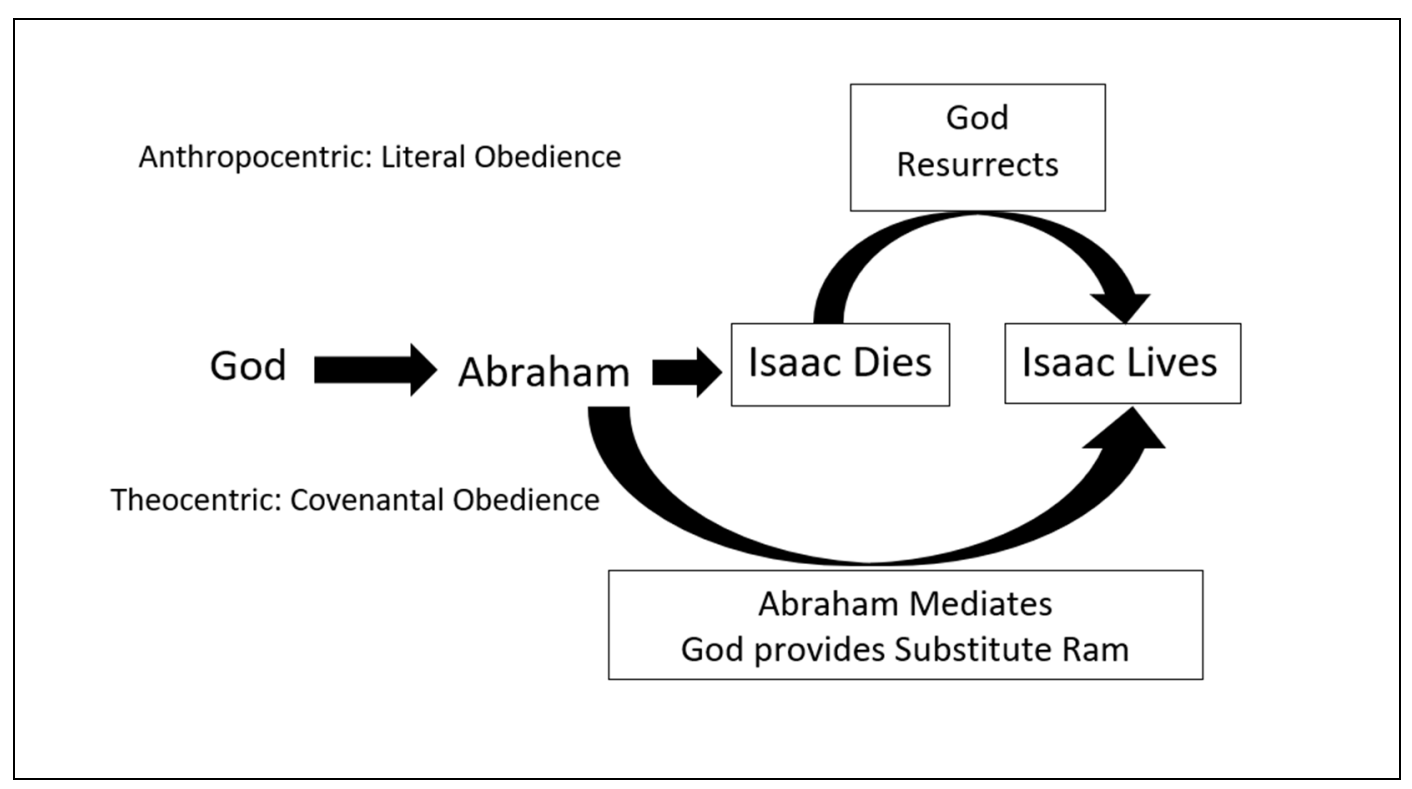

Fig. 4.5 The Covenant Hypothesis: Human and Divine viewpoints in the Aqedah.

If Aqedah narrative details are operationally rendered by shapes on the literary structure, it reveals an asymmetrical pattern with only one missing piece. For easier

\footnotetext{
${ }^{175}$ Boehm resolves the Aqedah diachronically by splitting the narrative historical-critically into two chronologically different strands. Regarding "questions as what Abraham should have done or whether he in fact did the right thing," Boehm says, "I do not know how to answer them and, in fact, would be suspicious of any account that claims to do so." Boehm, The Binding of Isaac, 3. I fully accept Boehm's suspicion and rest my case on a synchronic resolution of the tension by recognizing the synthesis of the divine and human viewpoints in the final form.
} 
comprehension of the structural elements on the literary triangle, I will depict Abraham's four verb clusters as circles, the two matching pairs of phrases ("Abraham lifted up his eyes and saw" and "so they went, both of them together") as simple text, and Abraham's monologue as boxed speech in Figure 4.6 below.

The pattern of operations on the right side of the chiastic triangle initially matches the left side ${ }^{176}$ but just after Abraham's taking up the knife to kill his son (v. 10), the rest of the components are missing. Instead of Abraham continuing as the sole antecedent agent (subject of the masculine singular verbs) for the test actions and speech along both sides of the literary structure, Abraham's reaching for the knife forces the angel of $Y H W H$ (vv. 11-12) to interrupt and become the (masculine singular) subject just once, disrupting the overall pattern. This interruption is followed by the displacement of the next two operational elements: the lifting of the eyes and the fourth verb cluster (v. 13b went, took, offered the ram) into the center circle of the literary triangle. The following awkwardness of the anticlimatic, accidental ("behold!") discovery of the ram solution, after the plot tension has been already broken by the saving angel, provides a hint that

176 The left side of the chiastic triangle from the bottom to the apex consists of: the test command (bottom left angle, vv. 1-2) followed by the preparation verb cluster for the journey (v. 3), the lifting of Abraham's eyes and seeing the site (v. 4), verbal exchange with the servants to remain (v. 5), transfer verb cluster of sacrificial accoutrements onto Abraham and Isaac (v. 6a). Then the paired inclusio "So they went both of them together" (v. $6 \mathrm{~b}$ and $8 \mathrm{~b}$ ) envelopes the apical central dialogue between Abraham and Isaac (vv. 7-8a). Then a verb cluster of preparations for the sacrifice follows (v.9) with the startling move "then Abraham reached out his hand and took the knife to slaughter his son" (v. 10). 
something has gone awry. Sketched out below, the displacement of the operational and oral rythmn of the story is obvious.

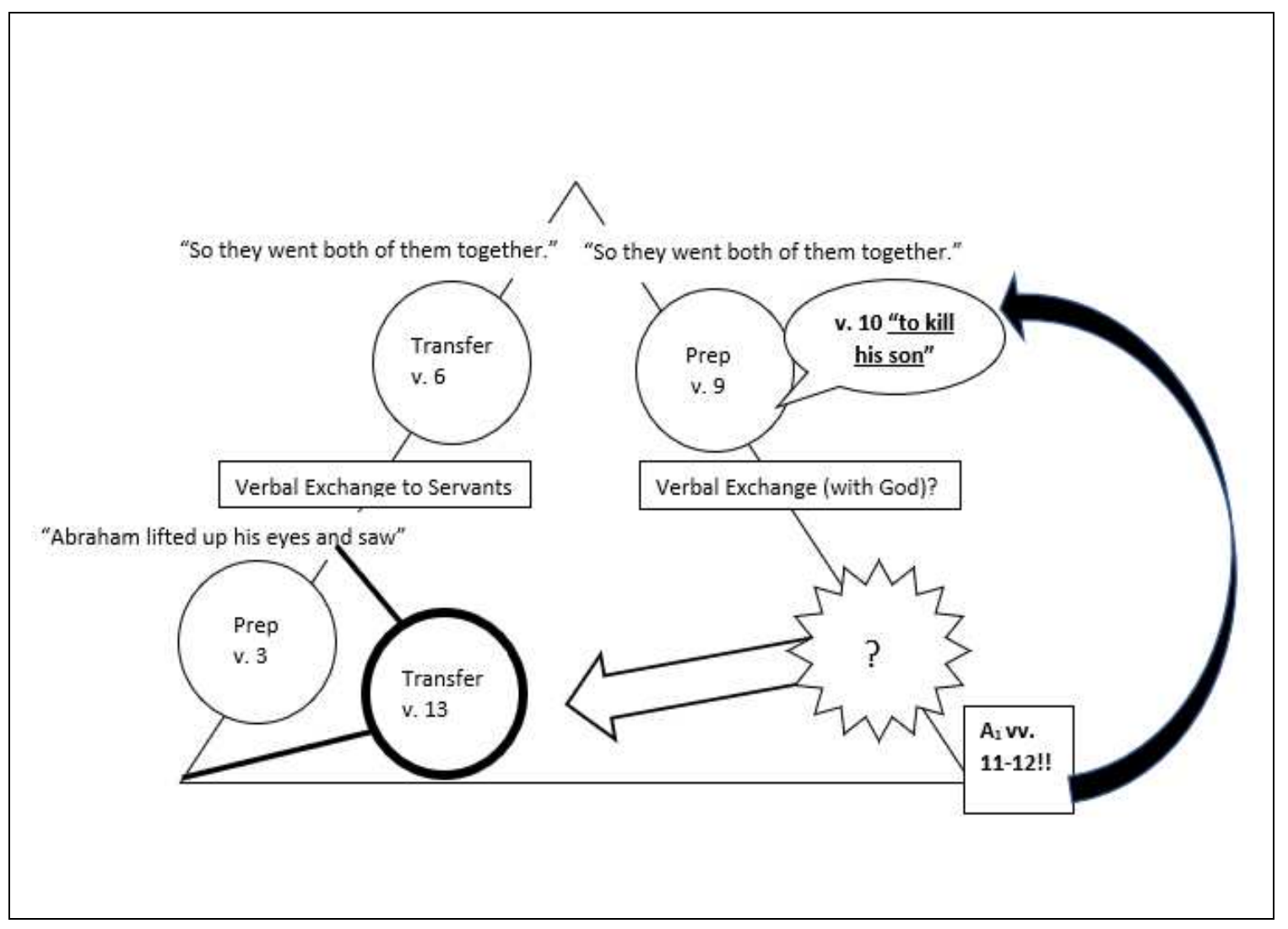

Fig. 4.6 Present literary structure reveals asymmetry.

Due to the underlying principle of symmetry in chiastic literary structures with the left-sided elements already in place, a matching sequence for the right side can be reconstructed ${ }^{177}$ from the existing elements in the Aqedah pericope (Fig. 4.7). This

${ }^{177}$ In attempting a reconstruction of a hypothetically ideal response to the test, it may appear that this study is indulging in a methodology akin to higher criticism and not remaining true to a posteriori 
historical-grammatical literary analysis that is the foundational method of this study. A rationale will be presented here based on the final form of the text. Historical-Critical scholars have a keen sense for recognizing features of literary continuity and discontinuity in the text and that school of thought believes later editors and redactors have left traces of their work in the final text. Fundamentalist scholars may have been too quick in dismissing these literary details because of assumed agendas of humanistic skepticism behind the search for these discontinuities.

Employing the Principle of Charity to the final form, namely, assuming that there is a rational purpose for leaving grammatical and syntactical irregularities in the text, could it be that these "speed bumps" in reading are subtle triggers designed to pedagogically elicit ponderings on theological nuances from sensitive readers? Christo Lombaard believes these were "purposely intended to indicate to their readers these internal editorial, and therefore, debating activities. These are indeed deliberately 'writerly' texts that both exhort and inform later, including modern, dialogue. The educational value of such insights can hardly be overestimated." Christo Lombaard, The Old Testament and Christian Spirituality:

Theoretical and Practical Essays from a South African Perspective (Atlanta, GA: Society of Biblical Literature, 2012), 128. According to Thiselton, a writerly text is "one which is capable of generating a plurality of meanings in the production of which readers can share." Thiselton, New Horizons in Hermeneutics, 98. Eckart Otto believed the purpose for these "apparent inconsistencies in the text, which call for texts behind the given text" were to indicate "narration time within the plot of narrated time." Eckart Otto, "A Hidden Truth Behind the Text or the Truth of the Text" in South African Perspectives on the Pentateuch between Synchrony and Diachrony, eds. Jurie H. le Roux and Eckart Otto (New York, NY: Clark, 2007), 19-28. However, this last rationale seems less likely since the Aqedah has no hesitation announcing narration time overtly as in the metalepsis of Gen 22:14 "As it is said to this day." So if, according to a conservative faith community's belief, the final form of the Bible was preserved by the Holy Spirit for instruction, this suggests that a theological rationale for any unusual style, syntax, grammar might be worth surmising about.

What are some literary details in the Aqedah that catch the attention of historical-critical scholars and what possible theological nuances might be indicated by their continuing existence in the final form of the text (regardless of theories about their origin)?

1. Style: On the micro-hermeneutical level we have already noted the dramatic stylistic differences between the poetic, repetitive, speeches of the angel of YHWH and the sparse narrative style of vv. 3-10, 13, 19, as well as the congruence between the first (vv. 11-12) and second angelic speeches (vv. 16-18) that lead historical-critical scholars to assume a later date for them. I would point out that the test command (vv. 1-2) is also repetitive, poetic and lyrical in contrast to the lean narrative and shares the name of Elohim with the first angelic speech (vv. 12). All three divine speeches also reference the same repetitive appellations for the victim Isaac. But no one assigns the initial test command to a later date on stylistic grounds for it would collapse the logical premise of the test. However, the concordance of divine verbal patterns in the Aqedah link the identity of Elohim to the angel of YHWH and the wide dissimilarity between the three divine speeches and the rest of the narrative argues for these three belonging together based on linguistic similarity.

2. Redundancy: "Why does the text say 'and he offered it [ram] up as a burnt offering instead of his son'? Obviously it was instead of his son, so why does the text have to explain?" Boehm, The Binding of Isaac, 11. Boehm reasons that this redundancy is a relic from the earlier version of the story without the angelic prohibition of vv. 11-12 that protects Isaac. In the original version, he surmises, this redundancy was necessary in order to assure the reader that in the story, Isaac is finally out of danger. In the final form of the text as it stands, the redundancy makes no sense if the angelic prohibition is understood to have already withdrawn the requirement for the sacrifice of Isaac. If, however, as the covenant hypothesis indicates, the angelic prohibition only cancels the direct method of fulfilling Isaac's sacrifice with Isaac's own body, then the remaining indirect method of ram substitution for Isaac may 
reconstruction hints that after the third cluster of verbs for altar preparation, a monologue

from Abraham to God would be expected - to correspond to Abraham's monologue to

the servants on the other side. If there is no verbal response from God to Abraham after

his mediation, we can expect from Abraham's previous habit (v. 4) that he would lift up

require the tagging "instead of his son" to theologically convey completion of the original test task.

3. Placement: Boehm thinks that v.10 and v.13 should flow together naturally-Abraham reaches for the knife to kill his son he lifts up his eyes and behold, a ram, behind! In Boehm's reconstruction the uninterrupted flow would emphasize the provided ram. But I would question why would a father intent on slicing his son's neck with a knife look up? The final form of the text puts the climactic accent on the angelic prohibition, with the ram as an afterthought. The Covenant Hypothesis uncovers a proposal that places the ram as the climactic divine answer to Abraham's prophetic intercession. Unfortunately, this possibility was never actualized.

4. Sense of Completion: Moberly believes vv. 15-18 are a later addition to the original story because "the structure and content of vv. 1-14 which are such that the story is complete by v. 14." He reasons: Abraham's obedience is demonstrated and affirmed by v. 12, God's rights to demand the firstborn and his mercy in providing the ram is concluded by v. 13, and the theme of the place and divine see/providing is legitimized by v. 14. Moberly, The Earliest Commentary on the Akedah, 304. A thematic sense of completion is determined by what an interpreter assumes as the divine purpose of the test. Moberly sees these three points as God's purpose for testing Abraham, other theologians may not agree. Moberly takes vv.15-18 seriously for "the fact remains that vv. 15-18 are the commentary that the OT itself contains." Moberly believes "the commentary is put in the mouth of the angel of Yahweh" for "the theological commentary in Gen. xxii 15-18 is to draw out the significance of Abraham's obedience in such a way that Abraham can be seen to have a role within the salvation-history of Israel akin to that of Moses." Thus, it "should be given a position of climactic significance within the Abraham cycle as a whole." I accept these verses as a divine interpretation of the Aqedah and not a human commentary that is later "put into the mouth of the angel of YHWH." Because the ending of a test or trial unpacks the whole event, where one accepts that explication to be, changes everything. If the divine interpretation of vv. 15-18 is taken as the test answer key, it unbinds the Aqedah very cogently.

5. Awkward syntax: The Hebrew term taken as 'akhar (behind, after) or 'ekhad (one) follows the sighting of the ram. Stylistically, 'akhar is usually accompanied by an orienting noun object, i.e., behind him (Gen 19:6) or after these things (Gen 22:1). In verse 13, 'akhar is left dangling by itself. A possible theological reason for not definitively demarcating the meaning to one or the other option for translation is that by leaving the term floating and unattached, it remains open to both translation possibilities: the spatial location of the ram for structural symmetry as well as retaining suggestive linguistic resonances with the single ram burnt offering on the Day of Atonement. Syntactical ambiguity allows for a more generous scope of possible and alluded meanings. 
his eyes and look around for any sign that God had heard him. Behind him in the bush is God's waiting ram. After the ram is substituted for Isaac and Abraham names the site, the angel of the YHWH would follow with one congratulatory speech (instead of two) that re-establishes the covenant on God with a complete list of seven (not six) covenant themes/blessings as specific commendations.

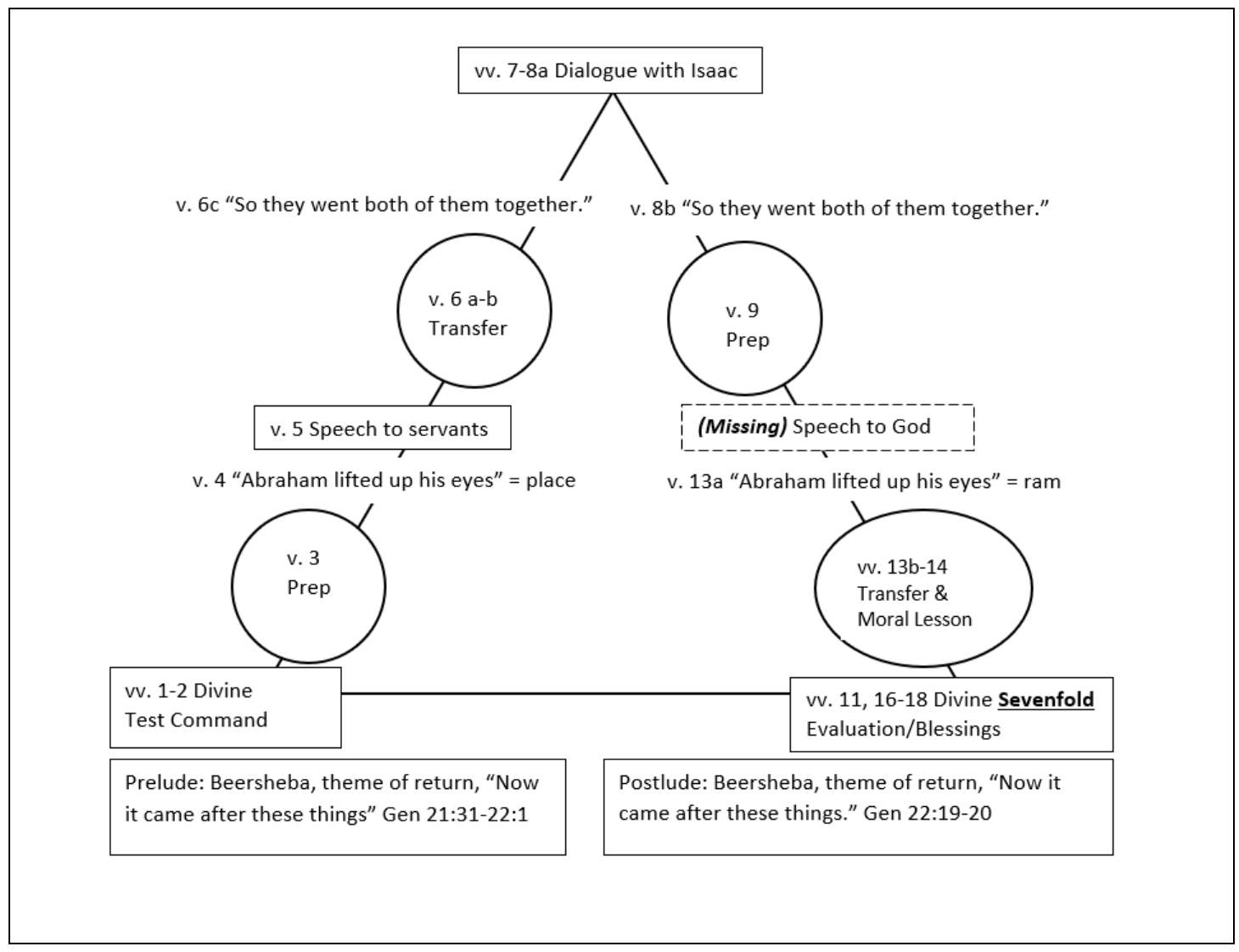

Fig. 4.7 Reconstruction of a symmetrical literary structure. 
In summary, the Covenant Hypothesis recognizes that in the final form of the Aqedah, the divine and human viewpoints are melded together imperfectly. As a new interpretation for the Aqedah it exhibits ten advantages over the traditional interpretations. (1) The Covenant Hypothesis is comprehensive because this theocentric interpretation does not displace but incorporates the traditional anthropocentric interpretations as valid regarding Abraham's intentions, which then required interruption and gracious redirection by God (vv. 11-12) to save Isaac and discover the theocentric solution of the ram. (2) It privileges and proposes a logically linear theocentric interpretation over the anthropocentric justification for the Abraham's choices which may or may not assume inconsistency in God's Aqedah behavior. (3) The Covenant Hypothesis retains consistency in the uniquely revealed character of Abraham's God while taking divine speech very seriously as precise and accurate without downplaying their exuberant poetical rhetoric. (4) The literary context of the preceding Abrahamic cycle becomes necessary to the new recognition of the Aqedah as a cumulative final test assessing Abraham's integration of all the previous revelations into his covenant character. (5) The Covenant Hypothesis is powerfully pastoral and pragmatic ${ }^{178}$ for it recommends understanding and responding to new revelations through an integrative

\footnotetext{
${ }^{178}$ This covenant hypothesis does not have to say with Martin Luther, "You are not Lot; you are not Abraham. Therefore you should not imitate what Lot and Abraham did ... Those who are not called by a specific command outside the rule, to be 'wonder men' (if I may use this expression), should keep within the rule. Then they will not transgress or err. But Lot, Abraham, and their like are 'wonder men'; their spirit is carried away beyond the law, beyond example and consequence. For they have an extraordinary call and impulse. You do not." Luther as cited by Elizabeth Palmer, Faith in the Hidden God: Luther, Kierkegaard, and the Binding of Isaac (Minneapolis, MN: Fortress Press, 2017), 108.
} 
hermeneutic grounded on the synthesis of past divine revelations, for Abraham's experiental journey with YHWH is his only "Bible" for understanding the challenging test command. (6) It recognizes the test design conveys divine respect for human intelligence because morally solving a crisis requires higher sophistication than mute compliance. ${ }^{179}$ (7) The Covenant Hypothesis demonstrates a greater degree of internal coherence, contextual consistency, correspondence, and realistic intuitive plausibility. (8) A fuller typology of Christ is implied by the Covenant Hypothesis: Isaac and the ram are already recognized types for Christ but this interpretation suggests Abraham was set up to be the clearest and fullest type for Christ (obedient servant, prophetic intercessor, covenant head, risk-taking self-sacrifice to preserve God's covenant). ${ }^{180}$ (9) This

\footnotetext{
${ }^{179}$ It has been recognized that the Aqedah test "structure matches exactly what a test is made up of: a task is presented, its completion is described and the passing of the test is determined." Seigfried Kreuzer, "Das Opfer des Vaters - die Gefährdung des Sohnes: Genesis 22," 62. However, the covenant hypothesis additionally recognizes: a mid-performance affirmative correction (vv. 11-12), the very specific test solution of the ram (v. 13) in relation to the anticipated solution of the lamb (v. 8), what the testee learned and the enduring legacy of the test (v. 14), a divine interpretation of the test that measures the degree of covenant integration in Abraham's character (vv. 15-18).

${ }^{180}$ Palmer sees Moberly's typology trying to connect Abraham with the Messiah metaphorically, tying fear to faith. "Abraham is a type of Jesus. ... Moberly defines Jesus' divine sonship as trust and obedience ... connects Jesus' divine sonship with Abraham's fear of God . . . equates Abraham's fear of God with the New Testament conception of faith ... faith is constituted by constant trust and obedience (both of which were manifest by Abraham in Genesis 22 and Jesus in Matthew's Gospel)." Elizabeth Palmer, Faith in the Hidden God: Luther, Kierkegaard, and the Binding (Minneapolis, MN: Fortress Press, 2017), 42 fn 113. See R. W. L. Moberly, The Bible, Theology, and Faith: A Study of Abraham and Jesus (Cambridge, UK: Cambridge University Press, 2000), 223, 226, 227. Hamilton sees the suffering servant in both father and son. He "makes an offering and sees his offspring (Isa 53:10). But like Isaac, who silently consented to being sacrificed, he was 'like a lamb that is led to the slaughter ... [yet] he opened not his mouth' (Isa 53:7). And like Isaac, he offered himself, rather an anyone else. But unlike Abraham, Isaac, or Job, the servant actually died (Isa 53:8)." Hamilton, Genesis 16-50, 117. Abraham was given a chance to experience a suffering akin to God's. "The agony which he endured during the dark days of that fearful trial was permitted that he might understand from his own experience something of the greatness of the sacrifice made by the infinite God for man's redemption. No other test could have caused Abraham such torture of soul as did the offering of his son. ... 'He that spared not His own Son, but delivered Him up for us all, how shall He not with Him also freely give us all things?' Romans 8:32.” Ellen G. White, Patriarchs and
} 
Covenant Hypothesis connects the fatherhood metaphor embodied by the ram to the exact literary center of the Aqedah, where Abraham responds as a loving father, "Here I am, my son." (10) God's own words hold the interpretive key to His superlatively designed test — the Aqedah unbinds itself.

To wrap up this section, the voice of the future faith community is inserted into the telling of the Aqedah by the etiological metalepsis ${ }^{181}$ of verse 14: "As it is said to this day, 'On the mount of the Lord, it/he shall be seen."' Doukhan believes this text implies Abraham had an inkling of the Day of Atonement. ${ }^{182}$ Westermann sees this as an etiology referring to the physical mountain, the sanctuary on the mountain, or an allusion to Jerusalem where Yahweh appears or is seen. ${ }^{183}$ Wenham takes the passive form of seeing as connecting to Abraham's history for it is "regularly used of the Lord appearing to men (cf. 12:7;17:1;18:1), thus making a link backward with Abraham's past experience and

Prophets, 154.

181 This metalepsis underlines Abraham's prophetic role of mediatorial communicator for subsequent generations who are expected to ponder this story for themselves and interpret it, which they do. The Torah binds subsequent generations to this narrative by the metaleptic promise. For further discussion on how metalepsis works in ancient text see Ilse Mueller, "Celebration and Narration. Metaleptic Features in Ex 12:1-13, 16" in Narratology, Hermeneutics and Midrash: Jewish, Christian and Muslim Narratives from Late Antiquity through Modern Times, eds. Constanza Cordoni and Gerhard Langer (Göttingen, AU: Vienna University Press, 2014), 25-37.

${ }^{182}$ Grammatically, Doukhan points out, "This is the same passive form that is used in Leviticus 16 to describe the appearance of the Lord on the Day of Atonement; 'era' 'eh 'I will appear' (lit. trans.: 'I will be seen') 'in the cloud above the mercy seat' (Lev 16:2). The grammatical correspondence suggests that Abraham has in view, through the offering of the ram he just performed, the service of the Day of Atonement, when the Lord (already identified as the lamb) will appear on the mercy seat. Jewish tradition has not only related the 'aqedah (22:7) to Passover, it also associated the 'aqedah and the Day of Atonement. In addition, the 'aqedah is a prominent motif in the liturgies of Rosh Hashanah and the Day of Atonement.” Doukhan, Genesis, 286.

${ }^{183}$ Westermann, Genesis 12-36, 363. 
forward to Israel's future experiences on the mountain of God (Exod 3:1-2, 16; Lev 9:4, 6, etc.)." ${ }^{184}$ This metalepsis therefore connects the Aqedah to the God who is seen and provides, the God who is present through history via the cult, temple and canonical events in the scriptures behind and in front of the text. Establishing historical credibility, the narrator's authority, and the continuing relevance of the meaning of the Aqedah for Abraham's descendants, this metalepsis conveys communal confidence that just as Abraham experienced on the mountain, true vision awaits those who go to the Mount of YHWH.

Interpretive Hypothesis

\section{Theory and Method for Interpretive Hypothesis}

The previously constructed understanding of the Aqedah will now be distilled into a summative interpretive hypothesis. The process of understanding was an informal, creative application of the hermeneutical method that first traced two trajectories in the narrative then analyzed the final form as their synthesis within one test. Next, matching the pattern of symmetry in the left side of the chiastic structure as uncovered at the level of micro-hermeneutics, meso-hermeneutical theology reconstructed a viable ideal test response to the test command by matching the chiastic sides (left and right sides of the triangle) to each other using the existing verses of the text. Now the free-ranging construction of understanding needs to be distilled into a succinct linear interpretive

${ }^{184}$ Wenham, Genesis 16-50, 111. 
hypothesis so it can submit to the next phase of testing by canonical validation or invalidation.

The method of transforming a discovery-constructive process of understanding into a publicly arguable interpretive hypothesis requires recognizing the crux of the argument. The crux is a test. The Bible explicitly tells the reader that the Aqedah is to be understood as a test between God and Abraham (v. 1). The conventional structure of tests, which is consistent with other narrative tests in the Bible, is: challenge, response, evaluation. But the logical sequence of unpacking a test is evaluation, challenge, then response. This last order uncovers the process of creating and administering a test because the tester must start with a concept of what they want to assess and the criteria they will use to assess it, create a construct to elicit it, apply that construct to a testee, then evaluate the test results against the predetermined criteria. Since the goal of an interpretative hypothesis is to explain the meaning of the Aqedah text, ${ }^{185}$ this interpretation will follow the Sola Scriptura paradigm of the text as a divine test.

\section{Application: The Covenant Hypothesis}

The Aqedah frames itself as a test, "God tested Abraham" (v. 1). As a test, the tester's final evaluation of the testee's test response indicates the original purpose of the test. God's final evaluation (vv. 15-18) of Abraham's complete test response (v. 16 "because you have done this") contains covenant themes and blessings ("not witheld your son," intensive blessings and multiplying, "stars of heaven," "sands of the seashore,"

\footnotetext{
${ }^{185}$ Hirsch, Validity in Interpretation, 136.
} 
"possess the gates of his enemies," "nations of the earth bless themselves") that correspond to six of Abraham's previous seven covenant revelations in retrograde order ${ }^{186}$ (Gen 21:12-14; Gen 17, Gen 15:5, Gen 13:16, Gen 12:7, Gen 12:1-3). The sixth, or next to last revelation (Gen 18) is notably missing from the list. Since Abraham's covenant revelations are referenced as the norm for divine evaluation, a logical interpretative hypothesis for the purpose of the Aqedah is testing the integration of the covenant revelations in Abraham's covenant identity.

This abductive hypothesis is supported by the design of the test command that requires actions corresponding to the covenant revelations. The logistical design of the test command requires Abraham to acknowledge his covenant name (Gen 17), to go (leklekha) to an unknown destination (Gen 12:1-3), to sacrifice at destination (Gen 12:7), to walk the land in faith, lifting his eyes for mountain (Gen 13:14-17), to gaze at stars in faith during overnight journey (Gen 15), and to have a son that trust God fully_-Isaac consents to be placed on altar (Gen 21:13). The endangerment to the covenant bearer Isaac, couched in emotive rhetoric that incites paternal compassion, calls for covenantbased training from the sixth revelation of Gen 18: prophetic intercession for the innocent based on God's righteous justice. An authentic intercession that is voluntary and heartfelt requires an authentic threat. The test command poses an authentic threat to the covenant and the promised son by Abraham's own hand. By requiring a three-day journey in close

${ }^{186}$ Connections of some of these covenant blessings to previous covenant promises have been noted by many theologians. This study expands to include all of them and clarifies the specific nature of these acknowledged links. 
proximity with the victim, the test provided time to remember and ponder on all that God had taught him. Thus, the test was designed to elicit all the lessons of the Abrahamic covenant.

However, Abraham's actions in the Aqedah discloses his assumption that the divine command required exact literalistic compliance irrespective of the content of the command (as do most traditional interpretations of the Aqedah). God did not intervene until the exact moment Abraham's actions stepped outside the boundaries of his covenant training, when "Abraham reached out his hand and took the knife to slaughter his son" (v. 10). Immediately, the angel of YHWH strongly prohibited the consummation of his faithfilled literalistic obedience while graciously commending his motive (v. 12) and ended with nuanced praise (you did not withold your son, your only son [missing: whom you love, Isaac]). Abraham then discovered the divinely provided ram that had been waiting and substituted it as a burnt offering "instead of Isaac" (v.13), calling the place " $Y H W H$ Yireh" (v. 14). At the end of the Aqedah, God re-established the covenant with Abraham on Himself and graciously but specifically listed themes and blessings corresponding to six of the seven covenant lessons as the final divine interpretation of Abraham's test response (v. 15-18). The summary conclusion is that Abraham has shown integrative and 
correctable obedience to the voice of God. Abraham then returns home with his servants

(v. 19).

\section{Judgment}

\section{Theory and Method for Judgment}

The Covenant Hypothesis has demonstrated internal validity by internal coherence (all three divine speeches can be aligned morally) and internal correspondence (almost all the narrative details are now captured as theologically functional). For external validation ${ }^{187}$ either a comparison can be made with every other competing hypothesis of the Aqedah using probability measures to assess whether the covenant hypothesis is the most cogent and comprehensive explanation for the Aqedah text, ${ }^{188}$ or, due to space limitations, the canon can be used to test this hypothesis by applying two

${ }^{187}$ External validation is necessary to escape the trap of (1) accepting a historically-socially constructed interpretation on the sole basis of the theologian's expertise, (2) asserting that the interpreter's direct connection to God makes their interpretation by inference, true, (3) that validity is a disguised term for "use" - a valid interpretation is defined by its goal (i.e. a feminist interpretation is valid if it furthers feminist aims), or (4) that there is no legitimate way to validate anything. External validation assumes an underlying coherence to the nature of reality. The Christian community of faith believes a valid interpretation of one part of the Bible will be coherent with sound understanding of other parts of the Bible.

${ }^{188}$ Ricoeur saw interpretive conflict as fulfilling the role of falsification: "To the procedures of validation also belong procedures of invalidation similar to the criteria of falsifiability emphasized by Karl Popper in his Logic of Scientific Discovery. The role of falsification is played here by the conflict between competing interpretations." Paul Ricoeur, The Model of the Text, 211-213. But as Hirsch points out, two disparate interpretations may have commensurate explanatory plausibility for the same text, without enough evidence to invalidate either one decisively. "Some of the 'internal evidence' can be generated only by a particular interpretation" and externally, "the interpreter is faced with the dilemma that some independent evident evidence favors one hypothesis, while other independent evidence favors its rival. This is the normal state of affairs in interpretation." Hirsch, Validity in Interpretation, 181. 
scientific methods with relevant sets of texts. ${ }^{189}$ To accomplish the latter, the Covenant Hypothesis must be distilled down to one specific variable for clarity in testing results. ${ }^{190}$

One way to narrow a narrative hypothesis into a one-variable testable hypothesis is to articulate a hypothetical abductive question ( $\mathrm{A}=$ abductive question) that is answered by the telling of the Aqedah narrative. Gadamer's method for finding this abductive question is by envisioning the Aqedah as an historically appropriate answer to it. ${ }^{191}$ This means the abductive question must be answerable by a divine test of a human being, it must relate to God's provision of Himself, it must relate to fear of God, it must require a concrete obedient human response to God in physical space and time, it must require an ethical worship and eschatological divine solution. Abraham Heschel's abductive question (A) "What does God ask of us?" 192 fits the above criteria. Heschel

\footnotetext{
189 The level of generality for an interpretive hypothesis of the Aqedah is stipulated by the anticipated scope of testing data. If the scope is limited to the pericope itself or by unambiguous references to the Aqedah, the hypothesis to be tested may remain specific and mainly descriptive. If the scope of testing data includes a class of other similar events based on the agent's moral response to a divinely threatened demise in the canon, then the interpretive hypothesis must be postulated in a form that suggests proscriptive actions for the agent corresponding to Abraham's role. Proscriptive recommendations are required for theological-ethical relevance to modern readers.

190 The problem in using direct comparison of other narratives to prove the validity of one narrative interpretation is that one set of readers will focus on the similarities between them and another set of readers will counter by focusing on the discrepancies between them. In addition, within each set of readers, subsets will weigh the narrative particulars differently regarding their significance. Thus, narrowing down the interpretation to one unique conceptual contribution at a time is an attempt to make the process of validation more precise and straightforward. This dissertation will test two particulars of the Covenant Hypothesis by the canon.

191 This process of articulating the presumed abductive question also allows the whole narrative to be understood in a relevant and deeper manner. Gadamer, Truth and Method, 363, 375-375.

${ }^{192}$ Abraham Heschel, Man is Not Alone: A Philosophy of Religion (New York, NY: The Noonday Press, 1979), 241.
} 
believes what God desires from humans is ultimate commitment and ultimate

reciprocity. ${ }^{193}$ This corresponds to the anchors of the Aqedah in the literary structure. In

the Aqedah, Abraham demonstrated ultimate commitment and ultimate reciprocity to

God in the three dialogues, to God twice (Abraham-Here I am) and to his son once (My

father-Here I am, my son).

That abductive question can be tapered further to pinpoint the one variable that

distinguishes between the traditional anthropocentric hypotheses and the theocentric

Covenant Hypothesis. The question becomes, "Faced with the specific test command to

sacrifice Isaac in the Aqedah — what did God want Abraham to do?" The two options for

the single variable are comply or solve. Now, the traditional hypotheses can be grouped

and articulated as the default null hypothesis ${ }^{194}\left(\mathrm{H}_{0}\right)$ and the Covenant Hypothesis as the

alternative hypothesis $\left(\mathrm{H}_{1}\right)$ respectively: 195

"What does God want from Abraham?"

$\mathrm{H}_{0}$ : In the test, God commanded the sacrifice of Isaac and wanted Abraham to comply by being willing to sacrifice Isaac thereby ceding the covenant.

\footnotetext{
193 "It is now our task to define the Jewish conception of religion. As noted above, religion-its human side - begins with a sense of obligation, 'with the awareness that something is being asked of us,' with the consciousness of an ultimate commitment. It is furthermore an awareness of 'God who sues for our devotion, constantly, persistently, who goes out to meet us as soon as we long to know Him.'

Accordingly, religious consciousness is to be characterized by two features - it must be a consciousness of an ultimate commitment and it must be a consciousness of ultimate reciprocity." Abraham Heschel, Man is Not Alone, 241.

194 The null hypothesis is not a derogatory term, it designates the default or original position. The alternative hypothesis usually refers to the new or proposed hypothesis.

${ }^{195}$ I acknowledge freely that whether the Aqedah test is approached from a literalistic compliance mindset or a covenant solution mindset, it was designed in such a way that almost all the covenant lessons (6 of 7) could be fulfilled by either approach of obedience except for the point of whether to destroy or try to save Isaac and the covenant. Thus, the two hypotheses will be articulated around this one point of stark difference.
} 
$\mathrm{H}_{1}$ : In the test, God commanded the sacrifice of Isaac and wanted Abraham to solve it by interceding for Isaac thereby embodying the covenant.

Two of the most rigorous testing methods available ${ }^{196}$ are the positivist hypothetical-deductive method ${ }^{197}$ and post-positivist falsification method. ${ }^{198} \mathrm{An}$ adaptation of these methods will be used to test the interpretive hypotheses by narratives and propositions of the canon, respectively.

\section{Tailoring the Hypotheses for Deductive and Falsification methods}

Hypothetico-deductive method: Predictives

Since God never again directly commands a child sacrifice, the scope of selection for the set of canonical testing narratives cannot remain limited to identical premises. I

${ }^{196}$ These two methods assume ontological objective reality exists. This metaphysical stance reflects the philosophical stance of the mainstream in my faith community of Seventh-day Adventists.

${ }^{197}$ The deductive method for testing rests on a positivist paradigm. It assumes a hypothesis is a true or untrue statement of a universally immutable reality and that logical deductive reasoning of its effects can be tested by empirical data which will prove it true or false, a binary conclusion. Egon G. Guba and Yvonna S. Lincoln, "Competing Paradigms in Qualitative Research" in Handbook of Qualitative Research, eds. N. K. Denzin, Y. S. Lincoln (Thousand Oaks, CA: Sage, 1994), 109-110; See also C. Mantzavinos, Naturalistic Hermeneutics, trans. Darrell Arnold (Cambridge, UK: Cambridge University Press, 2005) and Dagfinn Føllesdal, "Hermeneutics and the Hypothetico-Deductive Method," Dialectica 33, no. 3-4 (1979): 319-336. Where my application of the hypothetico-deductive method differs from Mantzavinos and Føllesdal is that they describe this method to be what interpreters usually do in ascertaining the best "fit" between several hypotheses to the original text under scrutiny, and I am using this method in a more stringent and objective manner by extracting deduced predictives from two competing hypotheses and testing them quantitatively against comparative narratives in the rest of the canon. In other words, if an interpretive hypothesis is a true understanding of this divinely set up situation, it should bear explanatory or predictive utility for other similar situations.

${ }^{198}$ Falsification is an example of post-positivist methodology. It assumes reality is independent of humans, but human grasp of that reality remains partial and incomplete. Thus, methods for knowledge can only approximate truth probabilistically. Falsification is an efficient way to apply the method of trial-anderror to fallible hypotheses by destroying imperfect models upon the discovery of one basic fact that contradicts it. Guba, "Competing Paradigms in Qualitative Research," 110. 
will need to expand the set to biblical situations where a covenant prophet/leader is informed of God's impending threat toward His elect. As in the Aqedah, the focus will remain on the response of the covenant prophet/leader. These narratives can then be compared using the question "What did the prophet/leader $d o$ in those situations?" These considerations result in the deduced predictive hypotheses $(\mathrm{HPr})^{199}$ :

$\mathrm{H}_{0} \mathrm{Pr}$ : Faced with a divine threat to the elect, a covenant prophet/leader complies with God's command.

$\mathrm{H}_{1} \operatorname{Pr}$ : Faced with a divine threat to the elect, a covenant prophet/leader intercedes with God's command.

Falsification method ${ }^{200}$ : Sub-hypotheses and falsifiers

For testing the interpretive hypotheses by propositions (prophetic utterances, laws, concepts from narratives) in the canon, our two hypotheses must be de-constructed

\footnotetext{
${ }^{199}$ Deduced predictions are then compared to other biblical narratives of the same narrowed class using the quasi-inductive method.

${ }^{200}$ Karl Popper's method of falsification seeks empirically basic statements contradictory to a proposed hypothesis to correct or negate it. Hypotheses that withstand the severest of tests are accepted, not as verified truth, but as statements closer to the truth than the ones which did not survive the testing ordeal. Thus, the search for truth is the willingness to be vulnerable to the hard facts of reality, to formulate superior conceptualizations of what is real and survive pruning by oppositional facts. Popper is very clear that empirical falsifiability only distinguishes what is scientific from what is not a scientific hypothesis. According to Popper, meaningful statements (religious, metaphysical, beliefs) may be true without having to be scientific or empirical (falsifiable). Karl Popper, The Logic of Scientific Discovery, (New York, NY: Routledge, 2002), 66-73. However, the question could still be asked, can Popper's methods be appropriately applied in the human sciences? "While doubt can be raised as to whether the social sciences are empirical or non-empirical, Popper classed the social sciences as empirical." Sylvain K. Cibangu, "Karl Popper and the Social Sciences" in Social Sciences and Cultural Studies, Asuncion Lopez-Varela, IntechOpen, DOI: 10.5772/38818, 24, accessed 19 October 2018, https://www.intechopen.com/books/social-sciences-and-cultural-studies-issues-of-language-public-opinioneducation-and-welfare/karl-popper-and-the-social-sciences. Because of the biblical principle of Tota Scriptura, Popper's method of falsification can be used on a document that is interpreted as self-consistent by a faith community.
} 
into succinct and clear sub-hypotheses. ${ }^{201}$ Then basic statements of falsification (called falsifiers) against each sub-hypotheses are formulated ahead of testing in order to remain as objective as possible. Finally, the application of the method of falsification is to search for texts that match specific falsifiers. The goal of this method is to eliminate faulty hypotheses.

This test method of falsification is rarely used for biblical interpretation so it requires explanation. The usual method of justifying a biblical hypothesis is to gather supportive texts and argue inductively from them. Like the hermeneutical method, this form of justification is very vulnerable to confirmation bias. The number of supportive texts is in direct proportion to the usually unstated selection criteria. Also unstated is the yardstick for stretching textual implications in order to classify them as supportive. Since criteria are not made explicit, this supportive-inductive method requires another equally competent scholar or opponent of the hypothesis to filter the amassed texts and evaluate the legitimacy of the conclusions. The casual reader can only choose between opposing experts and evaluate their arguments as far as they can. This reflects the current methods used in the Aqedah literature to support conflicting interpretations.

The testing method of falsification is far more efficient yet devastatingly harsh because it actively searches for one clear contradictory text to destroy the interpretive

\footnotetext{
${ }^{201}$ The Aristotelian method of reductionistic dividing or deconstructing the 'whole' into its 'parts' so they can be understood in structural terms is employed here to the hypotheses to make them amendable to the falsification method of contradiction. The reconstruction of the testing results may provide a deeper understanding and explanation for the original 'whole.' See Tom Butler, "Towards a Hermeneutic Model," 290.
} 
hypothesis as invalid. ${ }^{202}$ Even if the current application of the Popperian method in this dissertation fails to deliver the vaunted "death blow" to a hypothesis, ${ }^{203}$ this method is useful for clarifying the underlying assumptive beliefs for preferring a certain hypothesis.

202 The use of a falsifier from outside the pericope to threaten an interpretive hypothesis of the chosen pericope is not logical unless there is a crucial common denominator shared by both. In this case the common denominator is the source of the assertion and the body of work. God is presumed to be selfconsistent in character, holy and benevolent, the same entity throughout the canon. Therefore, a theocentric interpretive hypothesis can be tested by the canon. In addition, the canon is assumed to be selfcoherent.

${ }^{203}$ Hirsch is doubtful that direct falsification will work with most texts. "In the historical sciences such a result can seldom be achieved because decisive, falsifying data cannot be generated at will, and if such data had already been known, the two hypotheses would not have been in serious competition. Sometimes, of course, decisive data does by good fortune turn up, but usually neither competing hypothesis can be falsified, and both continue after their separate fashions to account for the evidence." Hirsch, Validity in Interpretation, 181. 
Both Aqedah hypotheses ${ }^{204}$ will be analyzed into their sub-hypotheses and potential falsifiers below.

$\mathrm{H}_{0}$ : In the test, God commanded the sacrifice of Isaac and wanted Abraham to comply with it by being willing to sacrifice Isaac thereby ceding the covenant. Sub-hypotheses:

1. Divine commands are identical to the divine will.

2. Obedience requires exact compliance. $H_{0}$ Canonical Falsifiers:

1. God never commanded child sacrifice.

2. God doesn't will child sacrifice.

3. Covenantal intercession is obedience.

$\mathrm{H}_{1}$ : In the test, God commanded the sacrifice of Isaac and wanted Abraham to solve it by mediating for Isaac thereby embodying the covenant.

Sub-hypotheses:

1. Divine commands are not always identical to the divine will.

2. Obedience requires covenantal compliance.

$H_{l}$ Canonical Falsifiers:

1. God commands child sacrifice.

2. God wills child sacrifice.

3. Exact compliance is obedience.

204 "After having produced some criticism of a rival theory, we should always make a serious attempt to apply this or a similar criticism to our own theory." Karl Popper, The Logic of Scientific Discovery, 65 fn1. 
The next phase of Judgment submits these forms to the norm of the canon (Tota Scriptura) for testing. However, before testing starts, a brief exposition of the rationale for using the canon as a unit for testing a singular narrative in one of the books is needed.

Rationale for canonical testing

Interpretive hypotheses of literary texts, statistics, history or Scripture face a unique hurdle for judgment. Deductive predictions and empirically reliable (in the sense of reproducible) results are extractable from subsequent experiments in natural science but they are not accessible from unique events or texts. Instead, textual or evidential data must be used quasi-inductively ${ }^{205}$ to validate or invalidate ${ }^{206}$ them. The testing of texts requires other texts which are similar enough to be relevant and considered part of the same set, but different enough to be useful for comparative evaluation. Thus, not any text is appropriate for testing another.

When the source of the testing data comes from outside the initial text, the interpreter must justify that source as a legitimate norm for the original text under

\footnotetext{
205 "In his early study in confirmation, Hempel advanced the thesis that as a rule, theories using theoretical terms do not yield observational predictions from finite observational reports without "quasiinductive' steps of reasoning." Ilkka Niiniluoto and Raimo Toumela, Theoretical Concepts and Hypothetico-Inductive Inference (Dordrecht, Holland: D. Reidel, 1973), 211. Hempel reserved the term inductive to refer to the development of a new hypothesis from observation data and used the term quasiinductive to refer to the testing stage or confirmation/disconfirmation of certain hypothesis-where an observation (part) is related to an already stated hypothesis (whole), even if that observation was initially deductively predicted by the hypothesis. Carl G. Hempel, "Studies in the Logic of Confirmation (II.)," Mind 54, no. 214 (April 1945): 101.

${ }^{206}$ Howard Sankey, "Scientific Method" in The Routledge Companion to Philosophy of Science, eds. Martin Curd and Stathis Psillos (London, UK: Routledge, 2014), 284-286. "To verify is to show that a conclusion is true; to validate is to show that a conclusion is probably true on the basis of what is known." E. D. Hirsch, Jr., Validity in Interpretation (New Haven: Yale University Press, 1967), 171.
} 
scrutiny. "Validity requires a norm-a meaning that is stable and determinate no matter

how broad its range of implication and application." ${ }^{207}$ Since an interpretation of a

biblical narrative is aimed at serving the community of faith, the norm of that faith

community provides a natural standard for legitimacy. Faith communities refer to a canon

for orthodoxy and the Christian community's canon includes the Hebrew Bible and the

New Testament, a demarcated class of normative texts. From that canon we can extract a

class of texts to test the hypotheses. ${ }^{208}$ Using the criteria mentioned in the previous

subsections, the Christian canon will be used to test the Covenant Hypothesis of the

Aqedah.

\section{Application of Hypothetical-Deductive Method}

The criteria for testing texts will require these three elements: God (or divine-like representative), an individual covenant prophet/leader, and a serious threat (mortality or divine abandonment) of the elect. Each narrative will be summarized with intertextual Aqedah resonances in italics to provide justifying context for their inclusion and insight into human behavior. Each human response will be classified as $\mathrm{H}_{0} \operatorname{Pr}$ (compliance)

\footnotetext{
${ }^{207}$ Hirsch, Validity in Interpretation, 126.
}

${ }^{208}$ What is the basis for narrowing down texts? Hirsch explains his criteria: "The more we know about the object, the narrower and more reliable we can make the class. Then, on the basis of what we know about other individuals belonging to the same class, we make a guess that the unknown traits of any object will be the same as the corresponding traits of most individuals in the class - more often than not. . . . the task of narrowing the class entails the ferreting out of as much detailed information as possible. Evidence from other works by the same author; evidence from all his works is less weighty than evidence from his works similar to the one at hand; evidence from all similar works by the author is less weighty than evidence taken from this similar work composed at the same period as the text under scrutiny, and so on, mutatis mutandis, for other class-defining traits." Hirsch, Validity in Interpretation, 188. Thus, the relative weight of the testing data is in direct proportion to its narrowness of class (internal linguistic and thematic similarities and external factors such as author, timing, genre, proximity). 
and/or $\mathrm{H}_{1} \mathrm{Pr}$ (intercession). As a reminder, the two predictive hypotheses with the

narrowed class of relevant narratives for testing are

$\mathrm{H}_{0} \mathrm{Pr}$ : Faced with a divine threat to the elect, a covenant prophet/leader complies with God's command.

$\mathrm{H}_{1} \mathrm{Pr}$ : Faced with a divine threat to the elect, a covenant prophet/leader intercedes with God's command.

The selected list of testing narratives from the Christian Canon are:

(1) Jacob wrestling with divine angel-Gen 32:22-31.

(2) Judah before Joseph as Prime Minister-Gen 44:14-34.

(3) Moses on Mt. Sinai-Exo 20:18-21; 32:7-14.

(4) Jephthah and his only daughter-Judg 11:30-39.

(5) David and Bathsheba's firstborn-2 Sam 12:14-23.

(6) David on Mt. Moriah-2 Sam 24.

(7) Jesus in Gethsemane-Matt 26:36-46.

(1) Jacob wrestling with divine angel, Gen 32:22-31. God had covenantally promised Jacob at Bethel, "Behold, I am with you and will keep you wherever you go and will bring you back to this land. For I will not leave you until I have done what I have promised you" (Gen 28:15). But after wrestling with Jacob at the River Jabbok and proving he was divine by incapacitating Jacob's hip, his divine antagonist said, "Let me go, for the day has broken." God commanded relinquishment of Himself which contradicts His previous covenant promise to not leave Jacob. Jacob replied, "I will not let you go unless you bless me." Jacob did not comply but pleadingly held on, ${ }^{209}$ exerting

\footnotetext{
${ }^{209}$ A disabled hip socket incapacitates any ability to walk or kneel, thus Jacob was probably prostrate on the ground, clinging to the lowest part of his antagonist's body to keep him from leaving, most likely an ankle. The poetic irony is that Jacob the heel-grabber of Esau at birth, who had always wanted to be Esau instead of Jacob - thereby idolizing his brother and grasping for Esau's firstborn privileges, is now finally (through divinely inflicted injury) relegated to grasping the actual heel of God, the One he was always meant to grab onto.
} 
a personal intercession for himself to get God's blessing and he obtained it. Then he seemingly complied and let the angel go, afterward. This validates both $\mathrm{H}_{0} \mathrm{Pr}$ and $\mathrm{H}_{1} \mathrm{Pr}$ in reverse sequence, intercession then compliance.

(2) Judah before Joseph as Prime Minister, Gen 44:14-34. ${ }^{210}$ Joseph is a source of food and authority in god-like fashion relative to his brothers. Because Judah has pledged himself as Benjamin's safety, when Joseph commands Benjamin to remain as his servant, Judah pleads with a Aqedah-like tale of an aged father losing his only son (ignoring the many half-brothers) and offers himself in Benjamin's stead. Joseph relents and reconciles with the family. Because Judah loved his father, he chose mediation and self-sacrifice instead of compliance and was successful. This validates $\mathrm{H}_{1} \mathrm{Pr}$ for intercession and adds the component of self-substitution for the victim.

(3) Moses on Mt. Sinai, Exo 20:18-21; 32:7-14. Mt. Sinai is where Israel is tested corporately at its base and Moses is tested individually at its summit. But the people were afraid and begged Moses to be their mediator. Moses said to the people, 'Do not fear, for God has come to test you, that the fear of him may be before you, that you may not sin."' Leaving them, and going up alone, "Moses drew near to the thick darkness where God was." While Moses was gone the Israelites worshipped idols. God threatened, "Now therefore let me alone, that my wrath may burn hot against them and I may consume them, in order that I may make a great nation of you." But Moses implored, "Remember

\footnotetext{
${ }^{210}$ The many shared linguistic and thematic links between this story of Judah's pleading and the Aqedah are: "father, an old man," "the child of his old age," "two sons," "he alone is left . . and his father loves him," "I may set my eyes on him," "if he should leave his father, his father would die," "one left me and I said, "surely he has been torn to pieces,"” "his life is bound up in the boy's life."
} 
Abraham, Isaac, and Israel, your servants, to whom you swore by your own self, and said to them, "I will multiply your offspring as the stars of heaven, and all this land that I have promised I will give to your offspring, and they shall inherit it forever.' And the Lord relented. Recalling the Aqedah where God had sworn by Himself, Moses had interceded successfully. Then Moses went down and punished them, complying with God's will to eradicate idolatry. So Moses' response encompassed both $\mathrm{H}_{0} \mathrm{Pr}$ and $\mathrm{H}_{1} \mathrm{Pr}$ in reverse sequence, intercession with God followed by compliance. ${ }^{211}$

(4) Jephthah and his only daughter, Judg 11:30-39. Jephthah promised God on his own initiative to sacrifice the first thing that came out of his home if God would grant him victory. His daughter was the first and with her consent (neither realizing this rash vow could be repented of with a sin offering: Lev 5:4-6) he "did with her according to his vow that he had made." Jephthah complied, though it was his own rash vow that set up the trap. This story is quite unusual in that $\mathrm{H}_{0} \mathrm{Pr}$ compliance is demonstrated without intercession. There is general consensus among Jewish rabbis that this choice of compliance by Jephthah was unfortunate and considered non-exemplary in contrast to Abraham's compliance in the Aqedah..$^{212}$

(5) David and Bathsheba's firstborn, 2 Sam 12:14-23. As punishment for adultery, God caused the baby of David and Bathsheba's from their affair to have a terminal

\footnotetext{
${ }^{211}$ It seems the Israelites didn't allow themselves to be tested by God. Since they did not submit to the testing, they did not allow God to put the Fear of God before them for they sinned against Him within forty days by idolatry.

212 "The Rabbis concluded also that Jephthah was an ignorant man, else he would have known that a vow of that kind is not valid; according to R. Johanan, Jephthah had merely to pay a certain sum to the sacred treasury of the Temple in order to be freed from the vow; according to R. Simeon ben Lakish, he
} 
illness. "David therefore sought God on behalf of the child. And David fasted and went in and lay all night on the ground" (v. 16). But after the baby died, David washed, worshipped, then ate, explaining, "While the child was still alive, I fasted and wept, for I said, 'Who knows whether the Lord will be gracious to me, that the child may live?' But now he is dead. Why should I fast? Can I bring him back again? I shall go to him, but he will not return to me" (vv. 22-23). David mediated but when not successful, he was fully compliant (instead of resentful, despairing or angry, as his servants expected). He worshipped and accepted the consequences of his failure at mediation. This supports both $\mathrm{H}_{0} \mathrm{Pr}$ and $\mathrm{H}_{1} \mathrm{Pr}$ in reverse order, intercession then compliance.

(6) David on Mt. Moriah, 2 Sam 24 and 1 Chron 21. David took a census then recognized he had sinned. Of three options for punishment, David chose three days of pestilence. But when Jerusalem was to be struck by the destroying angel, "the Lord relented from the calamity and commanded the angel, 'It is enough; now stay your hand." David saw the angel and said, "Behold, I have sinned, and I have done wickedly. But these sheep, what have they done? Please let your hand be against me and against my father's house." God directed David to sacrifice on the threshing floor of Araunah where David "built there an altar to the Lord and offered burnt offerings and peace offerings. So the Lord responded to the plea for the land, and the plague was averted from Israel." The angel then placed the sword of destruction back into its sheath, responding to David's

was free even without such a payment (Gen. R. 1.c.; comp. Lev. R. xxxvii. 3)." Emil Hirsch, Jewish Encyclopedia, s.v. "Jephthah (יפתח)," accessed 17 April 2019, http://www.jewishencyclopedia.com/articles/8584-jephthah. 
plea. David was called a "man after my [God's] own heart" (1 Sam 13:14, Acts 13:22).

Solomon later chose "to build the temple of the LORD in Jerusalem on Mount Moriah, where the LORD had appeared to his father David. It was on the threshing floor of Araunah the Jebusite, the place provided by David" (2 Chron 3:1). Intercessory offer of self-sacrifice followed by compliant burnt and peace offerings where the Lord had appeared marks the place for YHWH's temple. This validates both $\mathrm{H}_{0} \mathrm{Pr}$ and $\mathrm{H}_{1} \mathrm{Pr}$ in reverse order, self-sacrificial intercession followed by compliance with burnt offerings. ${ }^{213}$

(7) Jesus in Gethsemane, Matt 26:36-46. Jesus left most of his disciples at a spot, saying "Sit here, while I go over there and pray" (v. 36). Taking three disciples, he shared, "My soul is very sorrowful, even to death; remain here, and watch with me" (v. 38). Going a little further he prayed, "My Father, if it be possible, let this cup pass from me; nevertheless, not as I will, but as you will” (v. 39). The second prayer was, "My Father, if this cannot pass unless I drink it, your will be done" (v. 42). The third prayer was "the same words again" (v. 44). Then he resolutely set himself upon the unavoidable path to his death on the cross, "See, the hour is at hand, and the Son of Man is betrayed into the hands of sinners. Rise let us be going; see, my betrayer is at hand"' (v. 45-46). Jesus demonstrates a unique fusion of mediation and compliance together in his prayer, undergirded by his willing self-sacrifice as the Lamb of God. This validates both $\mathrm{H}_{0} \mathrm{Pr}$ and $\mathrm{H}_{1} \mathrm{Pr}$ but instead of the sequence of intercession followed by compliance as in the

\footnotetext{
${ }^{213}$ The last verse acts like a postscript on the event by telling the reader that the tabernacle was in Gibeon at this time "But David was not able to go there to inquire of God, because he was terrified by the drawn sword of the angel of the Lord" (I Chron 21:30). It seems the Fear of God was instilled by the angel's appearance to David at Mount Moriah.
} 
previous examples, Jesus blends both of them in one seamless supplication, his intercession is mingled with compliance all the way through and ends with offering himself as the sacrificial victim who pays the ultimate price with his life.

\section{Results of Deductive Method}

Out of the seven selected narratives, six of them $(1,2,3,5,6,7)$ validate intercession as part of the obedient response of a covenant prophet/leader. Five cases (1, $3,5,6,7)$ demonstrate both responses, first intercession then compliance. In addition to intercession, three $(2,6,7)$ offer themselves in substitution for the victims, and two $(6,7)$ offer sacrificial offerings. Jesus (7) seamlessly combines all the components: intercession and compliance, substitution and self-sacrificial offering in His response. The results indicate that intercession is a biblically allowable response to an Aqedah-like situation with Jesus embodying and integrating all the possibilities in His exemplary redemptive response.

\section{Application of Falsification Method}

Falsification requires only one ${ }^{214}$ basic text per falsifier to undermine either interpretive hypotheses, $\mathrm{H}_{0}$ and $\mathrm{H}_{1}$.

$\mathrm{H}_{0}$ : In the test, God commanded the sacrifice of Isaac and wanted Abraham to comply by being willing to sacrifice Isaac thereby ceding the covenant.

\footnotetext{
214 "We shall take it as falsified only if we discover a reproducible effect which refutes the theory." When asked how often an effect has to be reproduced in order to quality as a reproducible effect, Popper answered, "The answer is: in some cases not even once." Popper offered the example that the assertion "that there is a family of white ravens in the New York Zoo" can be tested in principle, even if that bird family is deceased, by appealing to "witnesses, documents, etc.; that is to say, by appealing to other intersubjectively testable and reproducible facts." Karl Popper, The Logic of Scientific Discovery, 66, $67 \mathrm{fn} 1$.
} 
Sub-hypotheses:

a. Divine commands are identical to the divine will.

b. Obedience is exact compliance.

$H_{0}$ Falsifiers with corresponding text.

1.God never commanded child sacrifice.

Jer 7:31 And they have built the high places of Topheth, which is in the Valley of the Son of Hinnom, to burn their sons and their daughters in the fire, which I did not command, nor did it come into my mind.

2.God never wills obedient child sacrifice.

Deut 12:31 You shall not worship the Lord your God in that way, for every abominable thing that the Lord hates they have done for their gods, for they even burn their sons and their daughters in the fire to their gods.

3. Covenantal intercession is obedience.

Exod 32:9-14 Now therefore, let Me alone, that My wrath may burn hot against them and I may consume them. And I will make of you a great nation."11 Then Moses pleaded with the Lord his God, and said: "Lord, why does Your wrath burn hot against Your people whom You have brought out of the land of Egypt with great power and with a mighty hand? ... 14 So the Lord relented from the harm which He said He would do to His people.

$\mathrm{H}_{1}$ : In the test, God commanded the sacrifice of Isaac and wanted Abraham to solve it by mediating for Isaac thereby embodying the covenant.

Sub-hypotheses:

a. Divine commands are not identical to the divine will.

b. Obedience is covenantal compliance.

$H_{1}$ Falsifiers with corresponding text.

1. God commands child sacrifice.

Ezek 20:25-26 Moreover, I gave them statutes that were not good and rules by which they could not have life, And I defiled them through their very gifts in their offering up all their firstborn, that 
I might devastate them. I did it that they might know that I am the Lord.

2. God wills child sacrifice.

Ezek 20:26 And I defiled them through their very gifts in their offering up all their firstborn, that I might devastate them. I did it that they might know that I am the Lord.

3. Obedience is exact compliance.

Jer 7:16 As for you, do not pray for this people, or lift up a cry or prayer for them, and do not intercede with me, for I will not hear you.

\section{Results of Falsification Method}

The search for falsifying texts has been too successful, the texts seemingly contradict each other. How can the texts regarding God's relation to child sacrifice be reconciled? One way to approach the problem carefully is to consider the nature of the apparent contradiction. Logical contradictions are not the same as operational contradictions. Logical contradictions are absolute abstracted statements of a mutually exclusive or self-cancelling nature (e.g., A is not non-A) and Karl Popper is correct to say that for formal logical contradictions, elimination of one or the other is necessary in the pursuit of an adequate hypothesis. ${ }^{215}$ Operational contradictions function in the real world

\footnotetext{
215 "Theories are put forth tentatively and tried out. If the outcome of a test shows the theory is erroneous, then it is eliminated: the method of trial and error is essentially a method of elimination: the method of trial and error is essentially a method of elimination. Its success depends mainly on three conditions, namely, that sufficient numerous (and ingenious) theories should be offered, that the theories offered should be sufficiently varied, and that sufficiently severe tests should be made. In this way we may, if we are lucky, secure the survival of the fittest theory by the elimination of those which are less fit." Karl Popper, "What is Dialectic?" in Conjectures and Refutations (London, UK: Routledge and Kegan Paul, 1963), 313. The remaining hypotheses left standing may not be true or accurate, but they are probably closer to the accurate truth if they have withstood the pruning method of falsification.
} 
of space, time, living entities and include intersubjective perceptions, commands, wants, and reactions. Operational contradictions may be contrastive sides or aspects of one thing, they may turn out to be complementary, situation specific, inquiry conditioned, or perspective/value laden (e.g., light is a particle/wave). ${ }^{216}$ Canonical texts refer to a divine dynamic agency operating intersubjectively with humans in a real world through the medium of human language. This means apparent contradictions may turn out to be paradoxes in which seeming opposites are theoretically related and/or resolvable.

Since elimination of any part of the canonical norm (Total Scriptura) is unacceptable for constructing whole biblical truth and the divine self-revelatory texts regarding child sacrifice indicate contrastive meanings, dialectic reasoning ${ }^{217}$ may help us grasp all that the Bible reveals. Each set of falsifying texts happens to support the opposite hypothesis, so the headings can be switched without changing the meaning or supporting logic and the textual meanings can be grouped accordingly. This gives the sets below.

Theocentric Covenant Hypothesis: Jer 7:31; Deut 12:31; Exod 32:9-14

1. God never commanded child sacrifice,

2. The thought of child sacrifice never came into His mind,

${ }^{216}$ Berry Groisman, "What is Dialectic? Some Remarks on Popper's Criticism," PhilSci Archive, [preprint] (2007), accessed 4 April 2019, http://philsci-archive.pitt.edu/id/eprint/3980.

${ }^{217}$ Here, I use the term dialectic reasoning for the logical endeavor to reconcile two seemingly contrastive points into a coherent whole in order to remain faithful to the whole of revealed divine revelation. This term is not meant to ascribe to the presuppositions of dialectic theology or dialectic philosophy (Hegel) with the connotations of evolutionary progress, irreconcilable or compromising metaphysical negations of truth. See Paul Tillich, "What is wrong with the 'Dialectic' Theology?" The Journal of Religion XV, no. 2 (April 1935): 127-145; David W. Congdon, The Mission of Demythologizing: Rudolf Bultmann's Dialectical Theology (Minneapolis, MN: Fortress Press, 2015); Christophe Chalamet, Dialectical Theologians: Wilhelm Herrmann, Karl Barth and Rudolf Bultmann (Zürich, CH: Theologischer Verlag Zürich, 2005). 
3. God hates child sacrifice,

4. God accepts mediation and relents from destroying His elect.

Anthropocentric Null Hypothesis: Ezek 20:25-26, Jer 7:16

1. God gave them bad laws of child sacrifice,

2. God defiled them through child sacrifice,

3. God devastated them, so they might know He is the Lord,

4. God forbade intercession, saying He will not listen

Focus on the type of verbs utilized suggests a direction for dialectic synthesis.

A. Theocentric Covenant Hypothesis-aligned texts use expressive verbs: the first three texts use verbs that refer to God's inner being (emotion, will, thought, responsive forgiveness). God Himself hates, never required, never harbored child sacrifice in his mind and responds to intercession by relenting from human destruction.

B. Anthropocentric Null Hypothesis-aligned texts use instrumental verbs: The last texts use verbs of divine interaction with recalcitrant wicked humans (gave, defiled, forbade, devastated) with the motive to turn them back to Him. God gave them bad laws, defiled them through child sacrifice, forbade intercession, devastated themso that "they might know that I am the Lord."

A possible conclusion to the dialectic analysis of these falsifier texts is that child sacrifice is against God's nature and is not expressive of who He is, yet God reserves the freedom and right to employ alien rituals if necessary for desperate salvific ends. Divine freedom is a challenge for human minds to understand. Now that the Covenant Hypothesis has demonstrated validity in respect to canonical testing, we now turn to the valuation or relevance of the validated Covenant Hypothesis for the Aqedah.

\section{Criticism}

Through the centuries, it has been the paradoxical nature of the Aqedah test that has continued to fascinate and repel great thinkers. Chrysostom saw the central issue in 
the Aqedah to be "God contradicts God, faith the faith, the command the promise." 218 Martin Luther ${ }^{219}$ and John Calvin ${ }^{220}$ highlighted the divine paradox in God's words versus His previous words. For them, the human duty was to have faith that God would resolve His own mystery while complying with the divine test command. ${ }^{221}$ Immanuel Kant moved the paradox to the human reception of the divine command and solved it by rejection since he doubted the veracity of the divine source due to the immorality of the test command. ${ }^{222}$ Soren Kierkegaard moved the paradox within humans as the paradox of authentic faith, a subjective double movement ${ }^{223}$ of full resignation to God yet fully expecting God to grant it back in this lifetime. ${ }^{224}$ According to Kierkegaard, Abraham's

${ }^{218}$ Kreuzer, "Das Opfer des Vaters_-die Gefährdung des Sohnes: Genesis 22,” 64.

219 “Abraham was actually tempted by God Himself, not concerning a woman, gold, silver, death, or life but concerning a contradiction of Holy Scripture. Here God is clearly contradicting Himself; for how do these statements agree: 'Through Isaac shall your descendants be named' (Gen 21:12) and 'Take your son, and sacrifice Him'?" Luther's Works: American Edition, 55 vols. General Editors: Jaroslav Pelikan, vols. 1-30; Helmut T. Lehmann, vols. 31-55 (Philadelphia, PA: Concordia and Fortress Press, 1955-1976) $4: 92$.

220 "His mind, however, must of necessity have been severely crushed, and violently agitated, when the command and the promise of God were conflicting within him. But when he had come to the conclusion, that the God with whom he knew he had to do, could not be his adversary; although he did not immediately discover how the contradiction might be removed, he nevertheless, by hope, reconciled the command with the promise; because, being indubitably persuaded that God was faithful, he left the unknown issue to Divine Providence." John Calvin, Commentaries on the First Book of Moses, Genesis 22:1-24.

${ }^{221}$ Jon Balserak, “Luther, Calvin, and Musculus on Abraham’s Trial,” 362.

${ }^{222}$ Kreuzer, “Das Opfer des Vaters—die Gefährdung des Sohnes: Genesis 22,” 65.

${ }^{223}$ Kierkegaard, Fear and Trembling, 85.

224 "Abraham did not renounce his claim on Isaac, through faith he received Isaac." Kierkegaard, Fear and Trembling, 77. 
faith goes beyond universal ethical rationality, exemplifying a "teleological suspension of the ethical." ${ }^{225}$ Martin Buber, who lived through the atrocities of the Hitler regime, strongly disagreed with any 'suspension of the ethical' because he believed it objectified humans: "In the realm of Moloch honest men lie and compassionate men torture."226 Emmanuel Levinas joined Martin Buber in moving beyond Kierkegaard's “excessive, isolated, and violent self-encapsulation" of Abraham as the particularized soul traveling in existential anguish up Moriah. Levinas sees Abraham recapturing meaning at the mountaintop by listening to the angel and dropping the knife in the sacred space of ethical intersubjective relation: "Abraham's attentiveness to the voice that led him back to the ethical order, in forbidding him to perform a human sacrifice, is the highest point of the drama." ${ }^{227}$

Many of these Aqedah interpretations would be classed by Hirsch in the category of theological or philosophical critiques, not interpretations, for they discuss the significance of the Aqedah to contemporary concerns. Their contribution lies in drawing out aspects of the Aqedah ${ }^{228}$ that illuminate the limits, challenges, and struggles in the life

${ }^{225}$ The teleological suspension of the ethical does not mean to discard the ethical for "what is said to be suspended in this sense is not forfeited but preserved in something higher, the latter being precisely its telos." Kierkegaard, Fear and Trembling, 83.

${ }^{226}$ Kreuzer, "Das Opfer des Vaters-die Gefährdung des Sohnes: Genesis 22,” 66.

${ }^{227}$ Laurence Bove, "Unbinding the Other: Levinas, the Akedah, and going beyond the Subject" in Interpreting Abraham: Journeys to Moriah, eds. Bradley Beach, Matthew T. Powell (Minneapolis: Fortress Press, 2014), 179. "Levinas says Kierkegaard did not go far enough in the story. . 'That he [Abraham] obeyed the first voice is astonishing: that he had sufficient distance with respect to that obedience to hear the second voice - that is the essential." Ibid., 171.

${ }^{228}$ Different interpretive trends arise from different communities. "Jewish and Christian interpretation, which is completely or overwhelmingly positive in its judgment, is confronted by a 
of faith. Most of them assume the paradox of the test command is a hidden divine mystery, accordingly, they focus mainly on the human response to the puzzling trial.

Because the focus remains mainly on Abraham's response to God $^{229}$ these can be considered anthropocentric approaches. At first glance, this may not seem fair for they demonstrate the importance of Abraham's compliance to a clear divine command to sacrifice Isaac, only differing from each other in the human virtue it demonstrates (love, fear of God, obedience, resurrection hope, morality, faith, absurd fidelity, etc.). But extreme compliance is not instrinsically a moral virtue. Absolute compliance is a wax nose that can serve any chosen god. Where interpreters may have veered wrong in their understanding of the Aqedah is in interpreting God's praise of Abraham's obedience through the filter of anthropocentric interpretations of Abraham's test actions that assumes everything he did was correct.

A theocentric interpretation of the Aqedah does the opposite. It interprets the nature of Abraham's obedience that is praised by God through God's own interpretation

passionate condemnation by enlightened humanism. . . . There is also an important difference of opinion, though nowhere near so great, within the exegesis which takes a positive view of the narrative, that is between Jewish and Christian interpretation. Christian exegesis sees the crucial point of the narrative in what happens between God and Abraham; so Luther, Kierkegaard, and von Rad following them; Jewish exegesis on the contrary sees it in what happens between God, Abraham, and Isaac. This is particularly obvious when the Jewish exegesis speaks of the Akedah . . . what is essential is the concrete event, whereas the Christian interpretation looks to a spiritual happening between God and man." Westermann, Genesis $12-36,354$.

${ }^{229}$ It is not only traditional interpretations that ignore Isaac, Kafka and Derrida offer modern reflections on the Aqedah that do the same. See Interpreting Abraham, eds. Bradley Beach and Matthew Powell (Minneapolis, MN: Fortress Press, 2014), 149-212. 
of Abraham's test actions. This is how a proper test works. The Tester's evaluation is what counts, not the testee's or the spectators' guesses.

The theocentric approach embraced the divinely provided interpretation of vv. 1518 as the Aqedah answer key that disclosed the divine purpose of the Aqedah by evoking the covenant revelations. Then the alignment of the test design and the test interpretation revealed the Aqedah to be a challenge test of Abraham's covenant identity. The Aqedah was a covenant crisis divinely designed to elicit ${ }^{230}$ an integrated covenantal response from Abraham that would lead to the grace-filled solution of a divinely provided ram. Though Abraham initially believed the test solution was the resurrection, "because the ram appears and the angel cancels the sacrifice, the resurrection of Isaac becomes unnecessary. As Genesis 22 proceeds, the solution to the contradiction between command and promise shifts from resurrection to ram." ${ }^{231}$ It is significant that the ram remains the capstone of the Covenant Hypothesis.

With all this in mind, does the Covenant Hypothesis resolve the paradoxes posed in the Justification section of chapter one?232 They were: (1) God's test command to immolate Isaac appears to nullify all previous commands and covenant promises. Because the divine test was designed to elicit from Abraham a comprehensive paternal

\footnotetext{
${ }^{230}$ According to Austin's speech-act theory, "Saying something will often, or even normally, produce certain consequential effects upon the feelings, thoughts, or actions of the audience, or of the speaker, or of other persons: and it may be done with the design, intention, or purpose of producing them." John Austin, How to do Things with Words, 101.

${ }^{231}$ Elizabeth Palmer, Faith in the Hidden God, 106.

232 These are found on pages 10-12.
} 
covenant response including an authentic, heartfelt, prophetic intercession, this required the test method of posing an authentic threat to the covenant and Isaac. (2) The two divine commands (to offer him up and to not do anything to him) concerning Isaac appear to contradict each other. As analyzed in this chapter, the two divine commands do not contradict each other for the angel of YHWH merely proscribes the direct method of sacrificing Isaac through harming him. The sacrifice of Isaac was always intended to be accomplished indirectly through the divinely provided ram representing Isaac. (3) The apex of the chiasm echoes Abraham's response toward his human son, not God. The essence of the covenant relationship between God and Abraham was to be reflected in Abraham's relationship to Isaac. Ethics is to reflect theology. God's ram as His representative to substitute for Isaac in sacrifice embodies the paternal responsiveness at the apex of the chiasm, "Here I am, my son," which verbally captures the epitome of parental love as ultimate responsiveness to meet the needs of the vulnerable. (4) God clearly praises Abraham for listening and obeying the voice of the Lord yet the actual solution to the test and the final obedient act of accepting and sacrificing the ram in the place of Isaac does not match a verbal substitutionary command in the text. Because the divinely provided ram sacrifice in the Aqedah is not linked to a divine verbal command yet the divine commendation refers to Abraham obeying God's voice, this suggests an expanded scope for God's "voice” beyond verbal and auditory communication.

Nevertheless, the Covenant Hypothesis may have a historical-critical Achille's heel. A historical consensus has existed among source-critical scholars that the divine 
speech of vv. 15-18 is a late editorial addition. ${ }^{233}$ Moberly recognizes this textual

problem ${ }^{234}$ while retaining his final focus for meaning on the given form of the Aqedah.

Moberly and I both agree that the last monologue fulfills a finalizing function in the

Aqedah and has underutilized explanatory potential. He believes it is a later addition to

the original narrative that has been reframed as God's voice, but I, with an ever growing

233 "There is no agreement, however, whether this represents the consistent work of just one or two editors, or whether this was a process extended over several centuries of editorial moulding of the patriarchal traditions. ... there is simply insufficient evidence available to allow any definitive resolution of date and context, surmises about which must necessarily remain hypothetical, any interpretation which substantively depends on relating the text to a historical context must itself be for ever [sic] tentative and hypothetical." Moberly, "The Earliest Commentary on the Akedah," 304, 312. Westermann classifies vv. 15-18 to be an addition because "there are generally several promises together which do not correspond to the situation narrated." Westermann, Genesis 12-36, 112. The Covenant Hypothesis provides powerful evidence to the contrary. Von Rad accepts that elements of the Aqedah "went through many stages of internal revision, whose material was, so to speak, in motion up to the end." Von Rad, Genesis, 243.

${ }^{234}$ Moberly presents his reasons for seeing the divine last speech (vv. 15-18) as a later addition. They are: three concerns of the test are resolved prior to the last speech (obedience, child sacrifice, seeingproviding), the last speech seems displaced as it comes after Abraham's name for the site instead of before it, its style and vocabulary are different from the rest of the story. Moberly, "The Earliest Commentary on the Akedah," 304-308. The Covenant Hypothesis posits one overriding purpose for the test (covenant identity/character) with multiple subsegments (love, faith, obedience, morality, 7 covenant lessons), so prior resolution of several subsegments is not unexpected before the test finally ends with a comprehensive interpretation given afterward. Moberly's preferred order-ram sacrifice (v.13), last speech (vv.15-18), naming of site (v. 14) — reflects a preference for a modern conventional order of resolution which is anachronistic to impose on an ancient text. The Covenant Hypothesis recognizes the linguistic style of the first and second angelic speeches to be alike, as does the historical critical scholar Omri Boehm, but doesn't excise one (as Moberly and historical critical scholars do) or both (as Boehm does) out of the narrative as later additions. Instead, their dramatic differences in style support their unique functions in the narrative as the mid-test corrective with titrated praise and the comprehensive evaluation of the test through covenant credits/blessings. 
number of scholars, ${ }^{235}$ believe this may be part of the original story and is what it claims to be, a divine interpretation.

There may be many more interpretive layers to uncover in the Aqedah. ${ }^{236}$ The Covenant Hypothesis is only one step in the long neglected direction of a theocentric intepretation of the Aqedah. As an interpretive option for understanding the Aqedah, the three conceptual strengths of the Covenant Hypothesis are: it adopts the given test paradigm more fully in explicating the narrative, it is theocentric in orientation, and it is resolutely faithful to the Abrahamic covenant context for understanding the Aqedah.

\section{Conclusion}

This chapter of meso-hermeneutics focused on a theological text interpretation of the Aqedah. To do this, meso-hermeneutics related the findings of the world in the text (illuminated by micro-hermeneutics) to the worlds of meaning behind (Abraham's covenant journey) and in front of it (canonical testing by later narratives and propositions). In addition, the role of the interpreter, who is present on every level of the spiral model, was carefully explicated and operational locations were clarified for the

${ }^{235}$ G. W. Coats, “Abraham's Sacrifice of Faith,” 395; J. Van Seters, Abraham in History and Tradition (New Haven, CT: Yale University Press, 1975), 230; T. D. Alexander, "Genesis 22 and the Covenant of Circumcism," 17-22; Crenshaw, A Whirlpool of Torment, 13.

236، One must from the first renounce any attempt to discover one basic idea as the meaning of the whole. There are many levels of meaning, and whoever thinks he has discovered virgin soil must discover at one that there are many more layers below that. . . there is only one limitation for the expositor, but it is absolutely valid: the narrative must not be interpreted as the representation of a general unhistorical religious truth. . . For it describes an event that took place in the sacred history which began with Abraham's call and whose enigmatic character is qualified only by this realm." Von Rad, Genesis, 243244. 
theological principles of Sola Scriptura, Tota Scriptura, Viva Scriptura, and Prima Scriptura. Then Hirsch's four phases for interpretation were undertaken: (1) understanding, (2) interpretive hypothesis, (3) judgment, and (4) criticism.

As directed by the Aqedah text, an understanding of the Aqedah was constructed through the hermeneutical method by incorporating the micro-hermeneutical findings that included the pivotal Aqedah answer key in the final divine speech (vv. 15-18). The resulting theocentric hypothesis saw the Aqedah test as a covenant crisis designed to elicit a covenant response from Abraham. However, anthropocentrically, Abraham's action-verb clusters in the Aqedah revealed that he responded with radical compliance even as he faithfully struggled to reconcile God's command with God's previous promises. The angel of YHWH thwarted the consummation of Abraham's literal compliance and Abraham obeyed him, then fulfilled the test command by sacrificing the divinely provided ram as Isaac's substitute. A divine interpretive monologue ends the test by re-establishing the covenant on Himself while bestowing incomplete covenantal blessings in a systematic retrograde manner. This interpretive hypothesis that explains the final form as the synthesis of two viewpoints (divine and human) is the Covenant Hypothesis.

For testing, the Covenant Hypothesis was re-articulated into two distinct interpretive hypotheses $\left(\mathrm{H}_{0}\right.$ and $\left.\mathrm{H}_{1}\right)$ and tested by the canon through the hypotheticaldeductive and falsification method. Integrative and dialectic reasoning melded the results into nuanced theological constructs which await future expansion by systematic theology. 
Finally, a criticism on the paradoxical nature of the Aqedah illustrated how the Covenant Hypothesis resolves them.

The weakness of the hermeneutical spiral model on the meso-hermeneutical level is that it does not provide one universal logical method for theology. Theology has multiple concentrations requiring different methods and tools, so the theological goal must utilize the appropriate method. The true strength of the spiral model for mesohermeneutics is that it reveals the actual interactive dynamics between the text with its biblical worlds of meaning and the theologian/interpreter with their personal worlds of meaning. It demonstrates how the horizons of meaning fuse, where the principles of Sola, Tota, Viva and Prima Scriptura operate, and it offers a way to norm interpretive hypotheses by canonical testing with critical evaluation. In short, the hermeneutical spiral model at the level of meso-hermeneutics reveals the necessary conditions that make credible theological meaning possible. The next chapter on the level of macrohermeneutics will delve into the basic presuppositions that underlie interpretive hypotheses and demonstrate how the text is able to direct metaphysical exploration as well. 


\section{CHAPTER 5}

\section{A MACRO-HERMENEUTIC FOR THE AQEDAH}

\section{Introduction}

From the micro and meso-hermeneutical levels of analysis through the Axial Model $^{1}$ a new interpretation for the Aqedah has emerged, the Covenant Hypothesis. ${ }^{2}$ This chapter addresses the third level of the Axial Model, the macro-hermeneutical level, where the presuppositions of the interpreter encounter metaphysical insights from the world of biblical philosophical meaning emanating from the text. The paired worlds of philosophical meaning about God and the cosmos are envisioned in the Axial Model as situated above and below the text respectively, and constitute the vertical Y-axis, ${ }^{3}$ the broadest conceptual lens ${ }^{4}$ of the model.

This study has been progressing inductively through the Axial Model (micromeso-macro). However, if one begins at the macro-hermeneutical level, the sequence

\footnotetext{
${ }^{1}$ In the Axial Model the interpreter traverses in looping fashion a three-tiered (micro, meso, macro) hermeneutical spiral ramp anchored and normed by the axial axis of the biblical text.

${ }^{2}$ The Covenant Hypothesis interprets the Aqedah as a divine test of a covenant crisis challenge where God commands Isaac's sacrifice to elicit from the divinely trained Abraham a paternal and compassionate response of integrated covenant revelations.

${ }^{3}$ The Y-axis refers to the worlds of meaning above and below the text which comprise the macrohermeneutical level of analysis, the philosophical presuppositions of the text. The other two axes were the $\mathrm{Z}$-axis which was aligned with the text and time corresponding to the exegetical world within the text (micro-hermeneutics) and the $\mathrm{X}$-axis which represented the worlds of meaning behind and in front of the text corresponding to theology (meso-hermeneutics).

${ }^{4}$ Many thanks to Dr. Martin Pröbstle who suggested labeling the Y-axis in order to clarify its
} 
follows the deductive methodology of systematic theologians, for systematic theology starts with commitments to foundational presuppositions (macro), then the exegesis of all relevant canonical texts are performed (micro), resulting in new findings, relations, clarification or insights as theological fruits (meso). On the other hand, Apologetic theology starts on the meso-hermeneutical level and defends church dogmatics (meso) by appealing to the rational intuitions of the audience (macro) then cinches the correlation of the two with biblical evidence (micro). These unforeseen but affirming recognitions indicate that the sequence of the spiraling levels of the Axial Model accurately discloses how biblical hermeneutics operates.

The present chapter on macro-hermeneutics will be divided into four parts. A discussion of Kierkegaard's and Derrida's philosophical readings of the Aqedah will launch this chapter by illustrating the intellectual richness of the Aqedah test and the value of continuing philosophical engagement. Next, the metaphysical aspects of the Axial Model and the methodology of hermeneutical philosophy will be clarified. This will be followed by a macro-hermeneutical analysis of the Aqedah exploring aspects of function and importance. 
ontology, epistemology, axiology. Finally, a summary of the macro-hermeneutical findings will close this chapter.

\section{Kierkegaard and Derrida on the Aqedah}

The philosophical tradition of the Aqedah has been heavily influenced by Søren Kierkegaard's work, Fear and Trembling, ${ }^{5}$ with its paradoxical reflections on the nature of Abraham's great and anguished faith. Jacques Derrida's article "Literature in Secret: An Impossible Filiation"6 is less known but follows Kierkegaard's lead by delving deeper into the silent secret center of Abraham's decision. Together, these incisive and provocative philosophical works demonstrate a deep respect for the Aqedah story ${ }^{7}$ and reveal the profundity of the Aqedah for interpreting human existence.

\section{Kierkegaard's Four Paradoxes}

Kierkegaard believed that the singular uniqueness of Abraham resided not in his act of sacrifice but in the great faith that preceded and enabled this act. Since Kierkegaard understood the Moriah journey as demanded by God to obtain proof of Abraham faith, ${ }^{8}$

\footnotetext{
${ }^{5}$ Søren Kierkegaard, Fear and Trembling: Dialectical Lyric by Johannes de silentio, trans. Alastair Hannay (London, UK: Penguin Books, 2003).

${ }^{6}$ Jacques Derrida, The Gift of Death and Literature in Secret, trans. David Wills, $2^{\text {nd }}$ ed (Chicago, IL: University of Chicago Press, 2008). "Literature in Secret" was chosen as the focus of this discussion because it more closely follows the text of the Aqedah than Derrida's better-known work The Gift of Death, which was also on the Aqedah.

${ }^{7}$ Kierkegaard demonstrates deep respect for God and the biblical text. Derrida is not a traditional believer but deeply engages and respects the texts that he deconstructs, sometimes reading them even more closely than his detractors do.

8 "Then why does Abraham do it? For God's sake, and what is exactly the same, for his own. He does it for the sake of God because God demands this proof of his faith, he does it for his own sake in order
} 
when this proof was produced at the journey's end by Abraham's holding the knife over Isaac, Kierkegaard believed God's demand was met and the divine command was appropriately rescinded. All the other elements of the biblical story, God's three speeches, Abraham's dialogue with Isaac, the Angel of the Lord, the ram, and even the specific doctrine of resurrection, were downplayed by Kierkegaard who honed his philosophical focus to the last day of Abraham's anguished three-day journey ${ }^{9}$ to the altar site in Moriah.

Kierkegaard famously characterized Abraham's great faith, not as a confident contented state of certainty in God, but as a distressed, silent, conflicted anguish. ${ }^{10}$ Why is Kierkegaard's Abraham filled with anguish, distress and fear? ${ }^{11}$ According to Kierkegaard, genuine faith is characterized by paradox. ${ }^{12}$ Paradox strains and stretches

to be able to produce the proof." Kierkegaard, Fear and Trembling, 88 .

9 "What he yearned for was to accompany them on the three-day journey when Abraham rode with grief before him and Isaac by his side. He wanted to be there at that moment when Abraham raised his eyes and saw in the distance the mountain in Moriah, the moment he left the asses behind and went on up the mountain alone with Isaac. For what occupied him was not the finely wrought fabric of imagination, but the shudder of thought." Kierkegaard, Fear and Trembling, 44.

${ }^{10}$ Kierkegaard sarcastically mocked attempts to mitigate the anguish of Abraham by using metaphors to assuage the listener's discomfort. "What is left out of the Abraham story is the anguish ... to a son the father has the highest and most sacred of obligations. Yet anguish is a dangerous affair for the squeamish, so people forget it, notwithstanding they want to talk about Abraham. So they talk and in the course of conversation they interchange the words 'Isaac' and 'best'. Everything goes excellently." Kierkegaard, Fear and Trembling, 58.

${ }^{11}$ Kierkegaard, Fear and Trembling, 103.

12 "What I intend now is to extract from the story of Abraham its dialectical element, in the form of problemata, in order to see how monstrous a paradox faith is, a paradox capable of making a murder into a holy act well pleasing to God, a paradox which gives Isaac back to Abraham, which no thought can grasp because faith begins precisely where thinking leaves off." Kierkegaard, Fear and Trembling, 82. 
spiritually, socially, emotionally and relationally. Four paradoxes provide a conceptual map to Kierkegaard's philosophical introspections on Abraham and deserve further investigation.

First, "the paradox that gives Isaac back to Abraham is the one highlighted in the contrast between the knights of infinite resignation and of faith." ${ }^{13}$ Unlike the figure of a tragic hero who relinquishes a lower ethical good to achieve a higher ethical good within the universal mode of behavior, such as sacrificing one's own child to save the village or nation, ${ }^{14}$ Kierkegaard's two figurative knights escape the universal realm of ethics to obey the call of religion. ${ }^{15}$ The knight of resignation renounces and is willing to infinitely lose whatever God demands of him/her in a single movement of relinquishment, ${ }^{16}$ while the knight of faith never renounces what he/she loves ${ }^{17}$ but is just as willing to lose what is

${ }^{13}$ Merold Westphal, Kierkegaard's Concept of Faith (Grand Rapids, MI: Eerdmans, 2014), 41.

${ }^{14}$ Kierkegaard uses the examples of Agamemnon, Jephthah and Brutus as examples of those who murdered to obtain a higher ethical prize, the good of the nation or state. Kierkegaard, Fear and Trembling, 86-87.

15 "In his action he overstepped the ethical altogether, and had a higher telos outside it, in relation to which he suspended it." Kierkegaard, Fear and Trembling, 88.

${ }^{16}$ Kierkegaard, Fear and Trembling, 77.

17 “Through faith I don't renounce anything, on the contrary in faith I receive everything, exactly in the way it is said that one whose faith is like a mustard seed can move mountains. It takes a purely human courage to renounce the whole of temporality in order to win eternity, but I do indeed win it and cannot in all eternity renounce that, for that would be a self-contradiction; but it takes a paradoxical and humble courage then to grasp the whole of temporality on the strength of the absurd, and that courage is the courage of faith. Through faith Abraham did not renounce his claim on Isaac, through faith he received Isaac." Kierkegaard, Fear and Trembling, 77. 
demanded while simultaneously retaining faith that God will give it back in this finite lifetime, a double dialectic movement that appears absurd ${ }^{18}$ to human reason.

Second, Abraham's faith included the paradox of moral contradiction because "the ethical expression for what Abraham did is that he was willing to murder Isaac; the religious expression is that he was willing to sacrifice Isaac; but in this contradiction lies the very anguish that can indeed make one sleepless; and yet without that anguish Abraham is not the one he is." ${ }^{\prime 19}$ Kierkegaard saw the ethical or the universal (community modes for behavior $)^{20}$ as derivatively subordinate ${ }^{21}$ to the individual believer's absolute relation to God. Thus, if unmediated direct relation to God defines the telos of the Christian, the communal ethical must be suspended by the particular believer as a norm when it conflicts with God's command. This leads to the paradox that the particular believer may appear unethical to his community, when he/she is actually being superethical. ${ }^{22}$ This then leads to another paradox. The set of human universal or ethical norms

\footnotetext{
18 "The absurd is not one distinction among others embraced by understanding. It is not the same as the improbable, the unexpected, the unforeseen. ... On this the knight of faith is just as clear: all that can save him is the absurd; and this he grasps by faith. Accordingly, he admits the impossibility and at the same time believes the absurd; for were he to suppose that he had faith without recognizing the impossibility with all the passion of his soul and with all his heart, he would be deceiving himself, and his testimony would carry weight nowhere, since he would not have come as far as infinite resignation." Kierkegaard, Fear and Trembling, 76.

${ }^{19}$ Kierkegaard, Fear and Trembling, 60.

20 "In other words, the ethical as the universal is not something like a Platonic form of a Kantian principle, it is rather a concrete universal, some historically particular community to which individuals belong and whose laws and customs are the norms for their lives." Westphal, Kierkegaard's Concept of Faith, 43.

21 "This ethical relationship is reduced to the relative as against the absolute relation to God." Kierkegaard, Fear and Trembling, 98.

${ }^{22}$ Here, the meaning of super is the notion of extra, exceeding, outside the scope of the norm. "But
} 
now becomes a temptation to the knight of faith once they have chosen to step outside it, for the universal always remains capable of tempting (or more precisely, of socially shaming) the resolute believer away from enacting their absolute religous duty to God alone. $^{23}$

The third paradox is that Abraham's love for God meant death for Isaac. Yet, the sacrificial test paradoxically demanded intensification of Abraham's compassion for Isaac because "when God asks for Isaac, Abraham must if possible love him even more, and only then can he sacrifice him: for it is indeed this love of Isaac that in its paradoxical opposition to this love of God that makes his act a sacrifice. But the distress and anguish in the paradox is that, humanly speaking, he is quite incapable of making himself understood." 24

Fourth, there is a paradox hidden in Abraham's silence. Kierkegaard admits that though "it cannot be denied that secrecy and silence, as determinants of inner feeling,

now when the ethical is thus teleologically suspended how does the single individual in whom it is suspended exist? He exists as the particular in opposition to the universal. Does this mean he sins? ... If this norm cannot be said to repeat itself in a way other than that of sin, then judgement has been delivered upon Abraham. Then how did Abraham exist? He had faith. That is the paradox that keeps him at the extremity and which he cannot make clear to anyone else, for the paradox is that he puts himself as the single individual in absolute relation to the absolute. Is he justified? His justification is, once again, the paradox: for if he is the paradox it is not by virtue of being anything universal, but of being the particular." Kierkegaard, Fear and Trembling, 90.

23 "What we usually call a temptation is something that keeps a person from carrying out a duty, but here the temptation is the ethical itself which would keep him from doing God's will. But then what is the duty? For the duty is precisely the expression of God's will." Kierkegaard, Fear and Trembling, 88. And even more specifically, "The love of God can cause the knight of faith to give his love of neighbor the opposite expression to that which is his duty ethically speaking." Kierkegaard, Fear and Trembling, 98. Absolutist thinking respects no humane limits.

${ }^{24}$ Kierkegaard, Fear and Trembling, 101. 
really make for greatness in a man. ... I always run up against the paradox, the divine and the demonic: for silence is both of these. It is the demon's lure, and the more silent one keeps the more terrible the demon becomes; but silence is also divinity's communion with the individual." ${ }^{25}$ If silence can signal the absolute relationship to either the demonic or divine, ${ }^{26}$ how does Kierkegaard justify Abraham's silence? Kierkegaard believes Abraham's silence is not demonic- even as it facilitates Isaac's death ${ }^{27}$ — because it stems from his absolute determination to do the will of the God he loves. ${ }^{28}$ Abraham is silent for he cannot make himself understood to others, ${ }^{29}$ thus, even his reply to Isaac's question continues to be a form of silence, an ironic non-answer: "First and foremost he doesn't

${ }^{25}$ Kierkegaard, Fear and Trembling, 115.

26 "The demonic has that same property as the divine, that the individual can enter into an absolute relationship to it. This is the analogue, the counterpart to the paradox we are discussing. It therefore bears a certain resemblance to it that can prove misleading." Kierkegaard, Fear and Trembling, 123.

27 "His silence is not at all to save Isaac." Kierkegaard, Fear and Trembling, 137.

${ }^{28} \mathrm{He}$ cannot say "It is you who are to be sacrificed" because "with talk of this kind he would fall out of the paradox, and if he really wanted to talk to Isaac he would have to transform his own situation into that of a temptation." In other words, by being honest, he opens himself to the possibility of being dissuaded from obeying God's command. Abraham cannot say he doesn't know, because he does know: "He knows that God demands the sacrifice of Isaac, and he knows that precisely at this moment he himself is ready to sacrifice him." By saying God will provide a lamb, "he utters no untruth, for on the strength of the absurd it is after all possible that God might do something quite different." But ultimately, "he cannot say anything since what he knows he cannot say." Kierkegaard, Fear and Trembling, 142-143.

${ }^{29}$ Kierkegaard, Fear and Trembling, 107. 
say anything, and that is his way of saving what he has to say. His answer to Isaac has the form of irony, for it is always irony to say something and yet not say it." 30

All of these paradoxes are contingent on Kierkegaard's acceptance of the traditional interpretation of the Aqedah as an unconditional compliance test of Abraham's faith. What Kierkegaard exposes is the hidden paradoxical absurdity of Abraham's faith that brings reason up to its own limits and requires the leap of faith. What would happen to Kierkegaard's paradoxes if the Covenant Hypothesis was substituted as the interpretation of the Aqedah? Kierkegaard's four paradoxes shift in surprising ways.

The first Kierkegaardian paradox that brings Isaac back to Abraham highlighted the difference between the knight of resignation and the knight of faith as relinquishment (single movement) versus relinquishment with expectation of Isaac's return (double movement). Under the Covenant Hypothesis the premise for the two knights is clarified and a new "third knight" appears. Kierkegaard's knight of resignation renounces and infinitely relinquishes what is loved to his/her ultimate authority (single movement/complies with overt divine power); ${ }^{31}$ the knight of faith does not renounce but infinitely relinquishes with expectation of Isaac's miraculous return in this finite life as promised (double movement/paradoxical faith in latent divine power). ${ }^{32}$ However, the

${ }^{30}$ Kierkegaard, Fear and Trembling, 142.

31 "Through resignation I renounce everything, this movement is one I do by myself . . . this movement is one I make by myself, so what I win is myself in my eternal consciousness, in a blessed compliance with my love for the eternal being." Kierkegaard, Fear and Trembling, 77.

32 "Through faith Abraham did not renounce his claim on Isaac, through his faith he received Isaac. That rich young man, by virtue of his resignation, should have given everything away, but once he had done so the knight of faith would have to say to him: 'On the strength of the absurd you shall get every penny back, believe that!' And these words should by no means be a matter of indifference to the once rich 
knight of covenant faith intercedes based on God's character and claims God's justice with expectation of divine substitution as promised by God in the previous cut-animal covenant ritual of Genesis 15 (single sublimated movement of faith in revealed divine character).

The second Kierkegaardian paradox of moral contradiction judged Abraham's action by two opposing standards: as murder by ethical standards, yet God-pleasing sacrifice by religious standards. The Covenant Hypothesis reconciles the religious and ethical standards in covenant-based intercession. Covenant-based intercession must be grounded on God's justice and righteousness (not selfish interests or human ethics) and recognizes the absolute freedom and authority of God to accede or decline the intercession, this God-fearing attitude embodies the absolute religious standard. The intercessor is, at the same time, concretely pleading on behalf of another human being at risk which embodies the human ethical standard. Since Abraham did not actualize this covenant test option, divine intervention was necessary to save Isaac and redirect Abraham's focus away from harming Isaac, so that his focused gaze would be freed to look elsewhere for the divine solution that awaited him.

Kierkegaard's third paradox pits Abraham's love of God against Abraham's love for Isaac in an either/or rivalry while simultaneously increasing Abraham's love for Isaac because a sacrifice requires losing what one loves. This uncovers the underlying assumption that the true value currency of sacrifice is directly in proportion to the in a sorry state. Temporality, finitude is what it all turns on." Kierkegaard, Fear and Trembling, 77-78. 
intensity of pain and suffering of the offerer. While the Covenant Hypothesis aligns with Kierkegaard's insistence that Abraham's love of God should remain supreme, it does not pit Abraham's love for God in opposition to his love for Isaac. Instead, Abraham's love for his son Isaac is to be assimilated into Abraham's love for God because the future of God's covenant that will bless the world is tied to Abraham's Seed. Both loves must be preserved together. While the Covenant Hypothesis agrees with Kierkegaard that Abraham ought to love Isaac even more fervently for God's four appellations for Isaac purposely intensify paternal compassion — it does not agree with Kierkegaard's implication that this is in order to increase the value of Abraham's sacrifice by increasing his suffering in killing Isaac. Rather, the Covenant Hypothesis sees it as working in the opposite direction as God's rhetoric to intensify paternal compassion so that it may lead to covenant intercession and/or substitutionary redemption.

One unexpected insight on the Kierkegaardian paradox between love and death is that the Covenant Hypothesis unearths a hidden, unacknowledged love at the altar site. Abraham's self-preserving love had always been his most precious love, arguably even more than his love for Isaac, for Abraham's self-love had relinquished Sarah to Abimelech (Gen 20) after God had promised Sarah would give birth to Isaac in a year (Gen 17, 18). This means she was given away sometime within her gestational year. Thus, Abraham's self-preserving love had threatened Isaac's existence and the covenant before the Aqedah event. Relinquishing Isaac (in a sense, again!) in sacrifice only repeats Abraham's habitual relinquishment of family members to figures of authority, it doesn't alleviate the historic competition between Abraham's self-preserving love and his love 
for everything else. It must be remembered that by the time of the Aqedah, Abraham has relinquished every family member at least once (Terah, Nahor, Lot, Sarah, Hagar, Ishmael). Relinquishment of loved ones is not a new test for Abraham; it is his norm. Covenant intercession deals with this tension ${ }^{33}$ for a prophetic mediator knowingly bears the personal risk of their intercession. ${ }^{34}$

The fourth paradox is that silence can be either divine or demonic. Kierkegaard sees Abraham's silence as guarding divine communication, because talking to others is seen by Kierkegaard as succumbing to the temptation for human justification.

Kierkegaard's argument that others are not capable of understanding the nature of Abraham's test, tacitly assumes Kierkegaard's seventeenth century modern ethics as Aqedah background. If child sacrifice was a part of Abraham's historical-cultural milieu, as it may have been in ancient times, ${ }^{35}$ this argument fails. According to Kierkegaard, since Abraham's silence guards his singular obedience to God, his silence is linked to divine communication. The Covenant Hypothesis shifts from the anthropocentric focus of

\footnotetext{
${ }^{33}$ Had Abraham gone one step further and anticipated God's ram gesture by offering himself to take Isaac's place, that would definitively demonstrate that his fear of death was overcome by his love for Isaac and the covenant.

${ }^{34}$ The decision-maker appealed to may punish, reward, substitute or respond in any manner to the intercessor for the target victim. A mediator carries the personal risk for their oppositional stance, regardless of whether it stems from loyal (fear of God) or disloyal (rejection of God) motives.

${ }^{35}$ The fact that Abraham was willing to kill Isaac for sacrifice could imply that this form of worship wasn't unknown to him. Contrary to Kierkegaard, I have entertained the notion that Abraham's silence could be understood another way, that his contemporaries would too easily understand the divine demand for child sacrifice because it was common to the gods of his surrounding cultures. Thus, if Abraham was unwilling to have others think his singular God was the same as other bloodthirsty deities, this can also explain why Abraham kept this unexpected, yet ubiquitous divine demand for a child sacrifice a secret.
} 
Kierkegaard to the theocentric role of God in the Aqedah. It uncovers even more radical paradoxes in God's initial speech and ensuing divine silence. The divine test command is paradoxically both divine and demonic for God is certainly the divine speaker but as the Divine Tester, God speaks out-of-character by echoing the pagan demonic demand for human sacrifice. God's ensuing silence is understandable as a test method, but retains perilous moral paradoxes. If God directly communicates the test solution to Abraham and rescues His moral reputation, the premise of the test is destroyed as a test of Abraham's integration of the covenant into his character. If God remains silent, allowing Abraham to wonder if God harbors a demonic aspect in His character, both Abraham's faith and Isaac's life hang in peril. ${ }^{36}$ Thus, God's disciplined three day silence in the test also reveals the greatness of God's faith in humankind; the Divine Tester's silence demonstrates His confidence in the capabilities of the human testee to figure it out. The Covenant Hypothesis contributes one last point to Kierkegaard's reading of the Aqedah. In Fear and Trembling, Kierkegaard's Abraham is depicted as an acting, feeling, living being gripped in the throes of a crisis, an appropriate existential treatment

\footnotetext{
${ }^{36}$ In the Aqedah, morality is acutely contingent on the exact timing of divine silence. If God breaks His silence too early, Abraham will not struggle with a personal response and the test is no longer a test of Abraham's maturation of character. If God speaks one second too late, Isaac dies and must be resurrected to keep the covenant promises valid. Yet Christians realize that the possibility of Isaac's death through sacrifice with ensuing resurrection would more accurately foreshadow the future role of the Messiah. But within the historical context of the Hebrew Bible, allowing Isaac to be killed by his father in worship followed by resurrection effectively erases the moral difference between the worship of YHWH and the worship of Baal or Molech. The sole remaining difference between the two kinds of worship would then be the quantitative gradation of power (the resurrection capacity of Baal and Molech versus YHWH). Because this was unacceptable to the Angel of the Lord, He intervened before the knife plunged into Isaac: morality was not to be sacrificed to power on Abraham's altar (regardless of the content of Abraham's faith).
} 
of the human subject. But Kierkegaard's picture of God is reduced to an ahistorical, abstract non-personal source of absolute power and command. The Covenant Hypothesis fleshes out a richer picture of God by revealing His test communications were deliberately customized to God and Abraham's unique historical relationship. In God's carefully crafted test command, God juxtaposed Abraham's worst fear with Abraham's greatest hope in a test framework that rhetorically evoked their first communication to move to Canaan (Gen 12) while deliberately eliciting his natural paternal instincts to hint toward prophetic intercession (Gen 18). God's subsequent test correction (vv. 11-12) invoked the past themes of divine knowledge (Gen 18) and the fear of God (Gen 20) and God's final speech (vv. 15-18) acknowledges six of their previous seven encounters (Gen 12, 13, 15, 17, 18, 21). The God of the Covenant Hypothesis demonstrates large-scale, purpose-filled, historically-informed agency.

In the Covenant Hypothesis, Abraham also comes across as very humanly relatable with real hopes, finite fears, verbal sophistication and intuitive intelligence. If his Aqedah utterances are taken as sincere, they demonstrate a variable plot line. $\mathrm{He}$ conscientiously assumes literal compliance is demanded at first, yet remains fastidiously correctable in God-fearing faith and finally, with trained prophetic intuition he links the surprise of the ram to God's provision. Thus, the Covenant Hypothesis respects the existential aspects of both Tester and testee by appreciating the deep nature and timing of 
their interactions, feelings expressed through verbal rhetoric, individuality of differing approaches to the test, with historical consistency in character.

As with every great piece of literature, appreciation of what is overtly presented by the text must be balanced with what is pointedly absent from the text. Since the Aqedah has been acknowledged as a narrative that ingeniously enfolds deep meaning into the silences and crevices between the details, we turn now to the philosopher Jacques Derrida to appreciate the aspect of unusual secrecy in the Aqedah.

\section{Derrida's Double Secret}

The secretive silence of Abraham is what connects Jacques Derrida's deconstructive reading to Soren Kierkegaard's existential treatise on the Aqedah. But where Kierkegaard's locus for silence is in the hidden great faith of Abraham after his acceptance of God's test command, Derrida's locus for Abraham's silence hovers in the unknown abyss before the issuance of the test command—in God. For Derrida notes the fact that Abraham is silent, not only due to the nature of the test command but even more terrifyingly, because at the center of this secret—Abraham doesn't know why God imposed this command on him and by implication, neither do we. Thus, both philosophers are intrigued by the silence of the Aqedah and together, they explore the silence on both sides of the test command - secrets in the human and divine. For Derrida, the Aqedah is clearly a double secret. ${ }^{37}$ In his article "Literature in Secret," Derrida

\footnotetext{
${ }^{37}$ Derrida, "Literature in Secret," 129.
} 
explores the secret center of their shared secret using his philosophical method of

deconstruction on the Aqedah..$^{38}$

Deconstruction refers to Derrida's work on exposing the scaffold for meaning ${ }^{39}$ in

the text. ${ }^{40}$ Some of deconstruction's goals were to crack open dogmatic closed systems of

thought, ${ }^{41}$ to explicate the underpinnings of an overt meaning, ${ }^{42}$ and to subvert preference

\begin{abstract}
${ }^{38}$ Deconstruction is not the same as destruction. The goal is of deconstruction is not the annihilation or evacuation of meaning but the recognition of the unlimited plurality of meaning. It is disciplined thinking about the variable production of meaning. Deconstruction requires reading a text carefully with a heightened sense of possible irony using direct and indirect approaches to see what related meanings have to be assumed in order to bring out the present presence, the preferred concept. Derrida never definitively defined deconstruction but was clear on what it was not. It was not a disregard for any reference or dissolution of overt meaning, it was recognizing the undecidable complexity of the process in the text that creates the illusion of a "natural" and defined meaning or truth. Derrida's disruptive search was to uncover the hidden, marginalized, oppressed concepts that were overlooked and then to point out the productive yet elusive gap between them and the written word. John Caputo quotes Derrida saying, "It is totally false to suggest that deconstruction is a suspension of reference. Deconstruction is always deeply concerned with the 'other' of language," for "deconstruction is not an enclosure in nothingness, but an openness towards the other." John D. Caputo, The Prayers and Tears of Jacques Derrida: Religion without Religion (Bloomington, IN: Indiana University Press, 1997), 16-17.
\end{abstract}

${ }^{39}$ Deconstruction recognizes at least two processes that create the meaning of any term, that of its "spacing of difference" from the opposite term (whether present or absent from the text) and the infinite deference of related terms connected in "chains of signification that radiate in all directions" both synchronically and diachronically, an limitless deferral of full meaning. Deconstruction, as coined by the term différance is the marking "of the trace of difference." "Deconstruction" subsection in Gary Aylesworth, "Postmodernism", The Stanford Encyclopedia of Philosophy (Spring 2015 Edition), Edward N. Zalta, ed., accessed 5 June 2019, https://plato.stanford.edu/archives/spr2015/entries/postmodernism/.

40 The term text is not to be limited here to written work, but includes speech, art, rituals, events, anything worthy of careful scrutiny.

41 "Whenever deconstruction finds a nutshell — a secure axiom or a pithy maxim — the very idea is to crack it open and disturb this tranquility. Indeed, that is a good rule of thumb in deconstruction. That is what deconstruction is all about, its very meaning and mission, if it has any. One might even say that cracking nutshells is what deconstruction is. In a nutshell ... the paralysis and impossibility of an aporia is just what impels deconstruction, what rouses it out of bed in the morning." John D. Caputo, Deconstruction in a Nutshell: A Conversation with Jacques Derrida, 3rd ed. (New York, NY: Fordham University Press, 1997), 32.

42 "It's possible, within text, to frame a question or undo assertions made in the text, by means of elements which are in the text, which frequently would be precisely structures that play off the rhetorical against grammatical elements." Paul de Man's understanding of deconstruction as quoted by Moynihan, Robert, A Recent Imagining: Interviews with Harold Bloom, Geoffrey Hartman, J. Hillis Miller, Paul De 
in binary systems so that repressed ambiguity and hidden ambivalence are also acknowledged and the meaning of the text is opened to more than was previously assumed..$^{43}$ To these ends, Derrida destabilized accepted meanings by carefully analyzing overlooked traces - marginal aspects, metaphors or fault fissures — within the text that carried along a trace of what was hidden by it, the indicated absences in and by the text. ${ }^{44}$

Thus, the semiotic results of philosophical deconstruction were analogous to suddenly recognizing the vast ocean of repressed concepts that had been buoying up a constructed raft of meaning and that no part of this watery sea was intrinsically superior to another part. This means that for most readers, deconstruction left meaning adrift and readers, metaphorically, felt lost at sea. The limitless language network of infinitely deferred meaning, like the vast ocean water, presented no paths to follow. To address this human need for some order or direction amidst the newly recognized infinite network of possible linguistic meanings, there has been a philosophical movement toward constructive deconstruction ${ }^{45}$ that aspires to incorporate the critical insights of

Man (Hamden, CT: Archon Books, 1986), 156.

43 "To represent is to select, to select is to omit, to omit is to misrepresent." Martin Schiralli, Constructive Postmodernism: Toward Renewal in Cultural and Literary Studies (Westport, CT: Bergin and Garvey, 1999), 1. The retrieval of the repressed options that are required for the process of narrowing and clarifying meaning is characteristic of deconstruction.

${ }^{44}$ The possibility of meaning ensconced in the silence of the Aqedah experience intrigued Kierkegaard, Derrida and Auerbach who famously recognized that the most intriguing aspects of the test reside in the non-explicit nature of this narrative: as Auerbach noted, the Aqedah is "fraught with background." In this context it is fascinating that the demarcated (missing from an ordered list) and indicated (missing from paired chiastic symmetry) absences in God's evaluation and the Aqedah's literary structure that have led to the Covenant Hypothesis that something was missed by Abraham in his test response.

${ }^{45}$ Constructive postmodernism or constructive deconstruction is the attempt to "work productively and meaningfully within the limitations" of uncertainty that result from postmodern analyses and 
deconstruction into a fresh meaningful and productive framework. The Covenant

Hypothesis is amendable to that mode of thinking for it hears God's final words as

providing the context-faithful covenant framework for reconstituting the deconstruction

of the Aqedah. ${ }^{46}$ The ensuing discussion will initially present Derrida's deconstructive

insights on the Aqedah from his article "Literature in Secret," ${ }^{47}$ then the Covenant

Hypothesis will engage with his findings.

In "Literature in Secret," Derrida initially avers from proffering an interpretation

by merely offering a reading of the Aqdah, but then circles back and claims that his

presupposition underlies all interpretations of the story:

I would like to propose a reading of it, one that I will distinguish, in this case, from an interpretation. At the same time active and passive, this reading would be presumed

deconstruction. Resources used in the place of foundationalism to reconstruct deconstruction include "pragmatism, or common sense, or naturalism, or experimental method.” Lawrence Cahoone, From Modernism to Postmodernism, Blackwell Philosophy Anthologies (Malden, MA: Blackwell Publishing Ltd, 2003), 223. See also Martin Schiralli's Constructive Postmodernism and also Sacred Interconnections: Postmodern Spirituality, Political Economy, and Art, ed. David Ray Griffin (Albany, NY: State University of New York Press, 1990).

46 The difference between Derrida's deconstruction to undecidability and my reconstruction of specific and comprehensive meaning lies in the ontological distinction that Derrida rejects any center, norm or anchor for meaning in language and my study recognizes an outside originator, co-user of language, and norm for human meaning - God as the reliable explicator of meaning. Thus, God's words are to be taken as the most reliable set of utterances in the Aqedah. This may help explain why Derrida's treatment of the Aqedah leads to an aporic vacuum of non-meaning and this dissertation uses the theocentric debriefing at the end of the puzzling test (micro-hermeneutic) to make sense of all the preceding parts (mesohermeneutic) because God is accepted by the faith community as the most reliable speaker and communicator of truth in the Bible (macro-hermeneutic).

${ }^{47}$ Jacques Derrida, "Literature in Secret," 117-158. Derrida's handling of the Aqedah is consistent in both "Literature in Secret" and The Gift of Death for they expound related concepts. Derrida's Gift of Death deconstructs the morality of responsibility as requiring irresponsibility to everything else, the gift of death as inevitable for life, and silence as necessary for preserving alterity. His more text-oriented article on the Aqedah, "Literature in Secret," focuses on the meaning (which is, at the center, non-meaning) in Abraham's secret test, the purpose of Abraham's test as the singular compliance of keeping a secret, the silence and absolute nature of unconditional love, and finally, forgiveness for the unforgivable limitations of finite choices that puts everything else at risk. 
by every interpretation, by the exegesis, commentaries, glosses, decipherings that have been accumulating in infinite numbers of thousands of years. As a result, it would not be simple one interpretation among others. . . . It would also have the clarity and distinction of being a secret experience concerning a secret. What secret? Well, the following one: unilaterally assigned by God, the test imposed on Mount Moriah would consist precisely in proving [éprouver] whether Abraham was capable of keeping a secret: in short, "of not meaning to say. ${ }^{48}$

According to Derrida, the test tested Abraham's capacity to keep a secret ${ }^{49}$ at a

huge cost:

Now - and this is something that cannot be a simple interpretive hypothesis of mine - this request, this test, is consequently at least that of seeing just how far Abraham can go in keeping a secret, up to the point of the worst sacrifice, to the extreme testing point of the secret that is asked of him: that of death given, by his own hand, to what he loves most in the world, the putting to death of promise itself, of his love for the future and the future to come of his love. ${ }^{50}$

Usually, secrets protect a shared truth but Derrida reminds the reader that Abraham didn't know the secret in the center of the secret, the why behind the order. ${ }^{51}$ Thus Abraham's secret happens to be a double secret for "Abraham is held to secrecy quite simply because the secret remains a secret to him. He is therefore held to secrecy

${ }^{48}$ Derrida, "Literature in Secret," 122.

${ }^{49}$ Derrida's article is careful in differentiating between (1) the external secret of the test - this test proved Abraham's capacity to keep the test a secret from everyone else, and (2) the central secret reason why the test was imposed by God on Abraham, a secret Abraham didn't know. Since Abraham is presumed by Derrida to not know the divine reason or purpose for the test, Derrida concludes that the consequent meaning of the test can only pivot on the singularity of their bond, the unconditional nature of the commitment between God and Abraham.

${ }^{50}$ Derrida, "Literature in Secret," 129. Derrida does not believe the test was mainly about the threat to Isaac. He explains why: "Moreover, what interest could God have in the death of this child, even if it were offered as a sacrifice? That is something he will never have said or meant to say. The putting to death of Isaac therefore becomes secondary, which is an even more, monstrous eventuality." Ibid., 155.

51 "The sense of that order remained secret, even to him.” Derrida, "Literature in Secret," 121. 
not because he shares God's secret but because he doesn't share it." ${ }_{22}$ But unlike Job, who complains to God that he doesn't know the why behind his suffering, Abraham kept his secret perfectly, suffering in passive silence and actively refraining from putting the question to God..$^{53}$

Because Abraham has no clue why God has imposed this secret test on him, the secret center is actually a vacuum, this center "has no sense", and yet "everything will hang on this suspension of sense." ${ }^{54}$ This absence of meaning (relative to Abraham) at the center of God's test means Abraham's test response is not tied to a specific meaning. Thus, Abraham can only respond to the singular unconditional nature ${ }^{55}$ of what lies between them. The Aqedah is then, "the test of unconditionality in love, namely the oath sworn between two absolute singularities." ${ }^{56}$ As Derrida describes it, Abraham's silence is apt because it

at bottom, at the bottomless depth of this bottom - must mean (to say) nothing. . . In short, the secret to be kept would have, at bottom, to be without an object, without

${ }^{52}$ Derrida, "Literature in Secret," 129.

${ }^{53}$ Derrida, "Literature in Secret," 129.

${ }^{54}$ Derrida, "Literature in Secret," 155.

55 "For the secret of secrecy about which we shall speak does not consist in hiding something, in not revealing the truth, but in respecting the absolute singularity, the infinite separation of what binds me or exposes me to the unique, to one as to the other, to the One as to the Other [sic]." Derrida, "Literature in Secret," 122-123.

${ }^{56}$ Derrida, "Literature in Secret," 155. 
any object other than the unconditionally singular covenant, the mad love between God, Abraham, and what descends from him. His son and his name. ${ }^{57}$

Hence, Abraham's unconditional, absolute love for God has the potential to threaten all of his other loves including Abraham's love for Isaac. This is why after the test, Derrida imagines Abraham repenting for his decision, asking paradoxically for forgiveness from God (for who else can grant it?) for holding such overwhelmingly devastating love for God:

I ask you to forgive me for listening to you, too faithfully, for too much fidelity to my sworn faith, for loving you, for preferring you, for choosing you and letting myself be chosen by you, for responding to you, for having said "here I am," and as a result, for having sacrifice the other to you, my other other, my other other in the person of my other absolute preference, my own, singular and plural, the best of what is mine, the best of my own ones, here Isaac. ${ }^{58}$

One must not forget, Derrida reminds us, that Isaac is not only Abraham's son but the promise, the future, the covenant, the symbol for every other, the symbol of love for any other. For rejecting, for betraying everything and everyone else that exists, ${ }^{59}$ Derrida explains, Abraham must repent. ${ }^{60}$

At the end of his article, Derrida ties the theme of betrayal to literature that betrays Abraham's secret by making it public. Since Abraham had been so careful to

${ }^{57}$ Derrida, "Literature in Secret," 156.

${ }^{58}$ Derrida, "Literature in Secret," 126.

59 "From that moment on there is nothing more sacred in the world for Abraham, for he is ready to sacrifice everything. This test would thus be a sort of absolute desacralization of the world." Derrida, "Literature in Secret," 154.

60 "It was that promise itself that he almost sacrificed, and that is again why he asks God for forgiveness, forgiveness for the worst: for consenting to put an end to the future to come, and hence to everything that gives breath to faith, to a faith or oath that is sworn, to the fidelity of every covenant. As though Abraham, speaking in his heart of hearts, were saying to God: forgive me for preferring the secret 
keep this secret to himself, ${ }^{61}$ the biblical text goes against Abraham's ardent desire. ${ }^{62}$ But the betrayal doesn't stop there, literature betrays Abraham's secret another way. Literature can betray the holy secret by transmitting that sacred singular secret ${ }^{63}$ into a common public work (a routine retelling for others). In a way, all literature performs desacralization by converting sacred traditions into a secular form without acknowledging the holiness of its origins.$^{64}$ According to Derrida, this is not appropriate appropriation. ${ }^{65}$ Thus, "literature can but ask forgiveness for this double betrayal." ${ }_{66}$ Derrida concludes, "there is no literature that does not, from its very first word, ask for

that binds me to you rather than the secret that binds me to the other, to each and every other, for a secret love binds me to the one as to the other, and to mine." Derrida, "Literature in Secret," 126.

61 "Concerning God's precise, singular call and command, Abraham says nothing and to no one." Derrida, "Literature in Secret," 128.

62 "In the case of what descends from him, however, the singularity is sealed but necessarily betrayed by the inheritance that confirms, reads, and translates the covenant. By the testament itself." Derrida, "Literature in Secret," 156.

63 'If literature, the modern thing that legitimately bears that name, 'desacralizes' or 'secularizes' the Scriptures, holy or sacred Scripture, it thereby repeats the sacrifice of Isaac, stripping it bare, delivering it and exposing it to the world." Derrida, "Literature in Secret," 154.

${ }^{64}$ Derrida, "Literature in Secret," 157.

65 "There there [sic] is secrecy [il y a là du secret], and we sense that literature is taking over these words, without, for all that, appropriating them in order to fashion them to its own purpose." Derrida, "Literature in Secret," 120.

${ }^{66}$ Derrida, "Literature in Secret," 157. 
forgiveness. In the beginning was forgiveness. For nothing. For meaning (to say)

nothing." ${ }^{67}$

Now that, according to Derrida, Abraham's singular double secret (a secret test with and even more secret purpose) has been doubly betrayed (publicized and secularized) by becoming a part of literature, the question left begging and not addressed by Derrida is, can and should we try to discover the secret purpose in the center of God and Abraham's secret test? Since Abraham presumably didn't know that secret, is it hubris to think that we can find it?

And yet everyone keeps trying, even Derrida ${ }^{68}$ Kierkegaard thought the divine purpose of the test was to prove Abraham's great faith, an anguished silent faith of hidden paradoxes in tensive aporetic juxtaposition. Derrida thought the purpose of the test was to see if Abraham could keep a costly secret even to the point of losing Isaac.

${ }^{67}$ Derrida, "Literature in Secret," 157. I understand Derrida to be saying that literature does not inherently carry meaning within itself, for in the case of the Aqedah even the main character that was being tested didn't know the meaning of his own test. Derrida uses the Aqedah to point out that Abraham's test case uncovers the inherent emptiness of literature in regard to meaning, yet literature is widely assumed to be a carrier of meaning that hands down the secrets of sacred tradition to the masses in a public form for secular consumption. This is ironic masking and a betrayal of holy origins. Thus, Derrida cannot help but see the reader - as the locus for creating meaning when confronted with a text that inherently cannot carry it.

${ }^{68}$ This is the operational genius of the Aqedah as literature, it is not handed down through literature as having a clear univocal meaning but as an unsolved problem, a biblical Gordian Knot that has challenged religious and secular readers alike to ponder the significance of what Abraham was faced with and come up with multiple interpretations. The Gordian Knot is an idiom for a seemingly insoluble problem based on a legendary tale of Alexander the Great who came upon a knot in Gordium with a prophesy that it was only capable of being loosed by the future conqueror of Asia. Alexander didn't attempt to untie it but sliced through it with his sword and this was hailed by his men as a good omen for his Asian campaign. Nigel Cawthorne, Alexander the Great (London, UK: Haus Publishing Limited, 2004), 24-25. In this study, the Covenant Hypothesis perceives God's final monologue in the Aqedah as the double-edged sword that cuts and releases the Binding of Isaac. 
Kierkegaard's premise located the test meaning in what makes Abraham who he is;

Derrida's premise located the test meaning in what makes God who He is - beyond human comprehension.

According to the Covenant Hypothesis, God's own words in the Aqedah outderrida Derrida, deconstruct his deconstruction, in other words, subtly reveal what was assumed by Derrida to be hidden beyond human reach. The Covenant Hypothesis does not ascribe to the reader the creation of meaning but the discovery of it, it assumes God as the Lord of language utilizes language in ways that ironically stretch and grow our hermeneutical (hearing) abilities. Thus, meaning is contingent on how well we are trained or willing to be trained by God to understand what God is saying.

Ironically, Derrida didn't, but could have recognized that the Aqedah secret of why God tested Abraham happens to be outed by God in the test supplement of Gen 22:15-18. ${ }^{69}$ Not only is this section of the Aqedah routinely regarded by historical-critical scholars as later literary addition, functionally, a test evaluation does not have to be divulged $^{70}$ for a test to be a test. That decision to share is the prerogative of the Tester. Thus, God's interpretative unpacking of Abraham's test actions is properly a supplement

\footnotetext{
${ }^{69}$ For Derrida the concept of a supplement (supplementarity) was something added later to a supposedly complete entity which supplies a sense that is lacking, thus it is actually inherent or "inscribed within that to which it is added." Robert Bernasconi, "Supplement" in Jacques Derrida: Key Concepts, ed. Claire Colebrook (London, UK: Routledge, 2015), 19. Testing demonstrates this well. The grading of a test comes at the end as an added process, separate from test taking. However, grading assumes a test norm or standard is being used to evaluate the test response. This norm pre-existed before the test was given to the testee and in a real sense even determined the design and construct of the test. Thus, it chronologically follows the test but holds within itself the originary hidden premise of the test.

${ }^{70}$ This was made clear to me when I was told that I had passed my doctoral comps and no details about the assessment were made accessible.
} 
and a decentered-center ${ }^{71}$ that functionally provides, from its teleological position at the end of the story, the seven epiphany covenant as the test norm. The divine revelation of the covenant as the test norm uncovers the original conceptual framework for the purpose and design of the test and therefore allows a reconstruction of the deconstruction of the Aqedah.

How exactly does God's last speech retrieve the hidden divine norm/purpose? It is through recognizing the triggering $\operatorname{traces}^{72}$ in the list of covenant blessings. Some are overt and unmistakably echoes of the covenant (such as the stars in the sky $=$ Gen 15) and some are recognized as synonyms of that era (such as Jacob's use in Gen 28 and 32 of the sands of the sea = dust of the earth, here in the Aqedah it evokes Gen 13); others are linguistic hooks (multiply and blessings in absolute infinitive form $=$ the verbs multiply and blessings repeated three times $=$ Gen 17$)$ and explanatory methods (Seed will posess the gates of his enemies $=$ I give you this land of Gen 12).

But something unexpectedly remarkable happens when these traces (indicated absences necessary for meaning) are traced to their corresponding covenant encounters and back again to the present Aqedah articulations. The background Abrahamic covenant

${ }^{71}$ It is decentered in at least two ways. It is not at the center of the literary chiastic structure of the Aqedah but at the end of it, and it is not anchored on any logocentric center within the linguistic network of language but on the identity/character of a divine dynamic speaker (By myself I have sworn, says the Lord).

${ }^{72}$ A trace is, according to Derrida, a contingent condition that the present term or concept must evoke its absent or hidden opposite and related meanings in order to make any sense. Arthur Bradley, Derrida's Of Grammatology: An Edinburgh Philosophical Guide (Edinburgh, UK: Edinburgh University Press, 2008), 77, accessed 30 September 2019, ProQuest Ebook Central. God's last speech in Genesis 22:15-18 requires evocation of their past fuller meanings of covenant interactions in temporal-situational settings in order to make sense. 
gleams $^{73}$ through a previously unrecognized gap in this Aqedah list of covenant blessings. The trace corresponding to the sixth covenant meeting (Gen 18) is absent from the test answer key of Gen 22:15-18. In this manner, God out-derridas Derrida by an absence of an absence..$^{74}$ This subtle commnication appropriately reveals to Abraham and the competent reader what is missing from Abraham's test response while gently veiling Abraham's lapses from his son Isaac and the casual reader. Within the hermeneutics between intimates, silence speaks. ${ }^{75}$ Outsiders with limited historical context and a logocentric focus bound to overt utterances that are present, would miss this subtle form of communication completely. ${ }^{76}$

As a reconstructive paradigm, the Covenant Hypothesis fulfills the goals of deconstruction in four areas of traditional Aqedah interpretations. It accomplishes this by

\footnotetext{
${ }^{73}$ Deconstructionists "designate the crevice through which the yet unnameable glimmer beyond the closure can be glimpsed." Jacques Derrida, Of Grammatology, trans. Gayatri Chakravorty Spivak (Baltimore, MD: The John Hopkins University Press, 1976), 14.

${ }^{74}$ In God's last speech, what is present (list of covenant blessings) activates what is absent (covenant history of seven encounters), but what is absent and made present by the trace (through covenant memory) now reveals the presence of a new absence (the trace for the sixth encounter is absent from the list of covenant blessings).

${ }^{75}$ When a wife asks her husband if a new dress makes her look fat and the husband hesitates before answering, regardless of what he tries to say afterwards, she recognizes by the initial silence - that he has answered her original question in the affirmative. More apt to the list of six out of seven covenant meetings, I have six children. If my husband were to praise five of them, a stranger would not think anything was amiss while I would wonder immediately why he skipped over one of our children. The recognition of silence for effectively conveying meaning is noted in close friendships, sophisticated business negotiations, and is critical for certain kinds of humor. Abraham and God were close friends.

${ }^{76}$ Derrida's work tried to undermine the logocentric "history of metaphysics as the epoch of presence." Derrida, Of Grammatology, 143. The usual theological preoccupation with anthropocentric logocentrism and presence may explain why this divine assessment utilizing circumspect silence was unrecognized until now.
} 
initially destabilizing (deconstructing) then recovering (or reconstructing) the same concepts on the firmer foundations of Abraham's covenant.

First, the Covenant Hypothesis upsets rigid binary test expectations. Many readers expect binary test results from Abraham's test: either a pass or fail based on exact literalistic compliance. The Covenant Hypothesis understands God's speech as a carefully nuanced assessment that Abraham certainly passed his test even with an imperfect score, actualizing six of the seven covenant lessons. That this outcome was praised by God through divine superlatives is unexpected and speaks well of God's graciousness without reifying every one of Abraham's test actions as ideal. The Covenant Hypothesis further suggests that Abraham's literalistic compliance initially misdirected, then self-corrected when confronted by divine prohibition (v. 11-12). This means literalistic compliance is not evil or wrong, but certainly risky. In the place of literalistic obedience, the Covenant Hypothesis deduces from God's final conclusion (which exhibits traces to previous revelations) that integrative covenantal obedience was the kind of obedience God desired and praised Abraham for, which Abraham shows he was fully capable of.

Second, the Covenant Hypothesis destabilizes hierarchical ordering of binary religious values and indicates a way to re-conceptualize them. What are these hierarchical values? Value binaries construe the Aqedah as an inescapable bind that required Abraham to preferentially choose his love of God over his love for Isaac, obedience to divine commands over obedience to human compassion, and morality for God's sake over morality for humanity's sake. The Christian interpretation of resurrection hope may 
not require a choice between two options, but in the traditional interpretations of the Aqedah it often aligns them in paradoxical justification: Abraham's hope of Isaac's future resurrection provides moral justification for killing that same life in the present as ordered by God's command. Derrida's insight that every concept carries a trace of its opposite or related meanings renders absolute love as requiring death to all other loves, ${ }^{77}$ religious meaning as based on "no-meaning" (divine secrets beyond human comprehension),${ }^{78}$ and every responsible selective decision requiring an irresponsible sacrifice of every other alternate option. ${ }^{79}$ In contrast, the Covenant Hypothesis melds love for God with love for Isaac in mediation where God's character of love and justice becomes the very basis for saving Isaac's life. It sees prophetic intercession as a covenant-derived response to divine threats to the covenant, and covenant morality appropriates God's moral objective to bless every human being. Regarding the Christian juxtaposition of resurrection hope as justification for killing, the Covenant Hypothesis recognizes Abraham's resurrection hope stemmed from God-fearing motives, but even this God-fearing rationalization was countermanded by God through the angel (do not do anything to him!).

Third, Derrida's treatment of the Aqedah infers three aporias that expose the inherent limits of human finitude. Human finitude explains Derrida's observations that

\footnotetext{
${ }^{77}$ Derrida, "Literature in Secret," 154.

${ }^{78}$ Derrida, "Literature in Secret," 129.

${ }^{79}$ Derrida, "Literature in Secret," 126.
} 
(1) the human capacity to love is not infinite - different loves must compete for primacy which implies extinction of some is always a possibility, (2) human meaning is contingent on the network of human language that harbors no meaning in itself for it is not directly anchored to a referrent outside itself, (3) finite human resources require selective decisions that by necessity reject other options. However, the Covenant Hypothesis shows that God can modify each of them: (1) God can increase the finite human capacity to love and enlarge finite perspectives and options for expressing authentic love that is inclusive in nature, (2) God offers meaningful revelation in human language, anchored in the certainty of Himself as a trustworthy communicator, and (3) God can exceed foreseeable options by divine providence such as the hidden ram in a bush.

Fourth, most traditional interpretations assume God's will and Abraham's will are perfectly aligned in literal obedience in the Aqedah. Both Kierkegaard and Derrida assume one uniform unbroken trajectory of the two participants. The Covenant Hypothesis cracks opens this dogmatic, monolithic assumption by recognizing two trajectories intertwine until the altar site, where they diverge over one missed covenant option, reaching for the knife to kill his son versus interceding for his son's life based on God's character-Gen 18. Abraham demonstrated literalistic obedience but God desired covenantal obedience culminating in paternal prophetic intercession at the altar. The Covenant Hypothesis thus clarifies an original ethical divine purpose for the Aqedah test, 
though Abraham's literalistic obedience did accept divine correction to not kill Isaac and discovered God's ram.

In conclusion, the Covenant Hypothesis re-constructs Derrida's deconstruction of the Aqedah on the basis of God's own interpretation and covenant test norm without burying the insights of deconstruction or regressing back into a dogmatically closed and rigid system of thought. The Covenant Hypothesis satisfyingly explains why the secret purpose of the test had to remain secret even from Abraham. It was because the Aqedah was a test of Abraham's integrative incorporation of his faith into his character, as revealed through phronesis. Thus, the Covenant Hypothesis remains an open, permeable and porous interpretation because it inaugurates new connections between the Aqedah text and its context, reveals the assimilative integrative obedience desired by God, recognizes experiential variability in human hermeneutics, demonstrates the synthetic mediatory nature of memory (the phenomenon that makes present what is absent) for meaning, and the grace of God that delivers God-fearing believers in spite of themselves.

This section has demonstrated the interdependent relationship between the mesohermeneutical level of theological interpretation and macro-hermeneutical level of philosophy. The Covenant Hypothesis from the meso-hermeneutical analysis shows integrative, evaluative and generative capacity for the macro-hermeneutical level of Aqedah philosophy in conversation with Kierkegaard and Derrida's work. As a theory it appears capable of solving and explaining both problems and aporias from the text that have stumped other interpretations. Thomas Kuhn believed such problem-revealing and 
solving capacity of any theoretical model to be its strongest argument as an accurate representation of reality compared to other models with lesser abilities in this sense. ${ }^{80}$

Now it is time to turn to an exploration of the macro-hermeneutical implications of the Aqedah by direct examination of the text. The next section will depict the theory and methodology of the macro-hermeneutical level of the Axial Model for the Aqedah. Then the text will be plumbed for macro-hermeneutical insights.

\section{Model Cores and Macro-hermeneutical Methodology}

Sound "interpretation follows the path of thought opened up by the text." ${ }^{81}$ How does the text open up the metaphysical conceptual lens of the interpreter? This section will first elucidate the metaphysical nature and relationship between the Axial Model's two cores on the macro-hermeneutical level and clarify the methodology of hermeneutical philosophy. Then the metaphysical aspects of the text will be extracted systematically.

\section{Model Cores}

The simplest description of the Axial Model is that it consists of two cores interacting on a continuous spiral ramp. One core is the biblical text, the long axial

80 Thomas Kuhn believed paradigms or models were to be considered as advancement in truth based on their ability to resolve or better explain multiple anomalies arising from the object of study that had frustrated or were ignored by previous models. "A scientific theory is usually felt to be better than its predecessors not only in the sense that it is a better instrument for discovering and solving puzzles but also because it is somehow a better representation of what nature is really like." Thomas S. Kuhn, The Structure of Scientific Revolutions, 206.

${ }^{81}$ Ricoeur, "What is a Text?" 162. 
anchor and norm which emanates biblical worlds of meaning that form the spiral ramp. The other core is the punctate center of the interpreter's sphere, the self-identity of the human interpreter attached to its personal worlds of meaning. This section will probe the metaphysical nature of these two cores and their relationship to each other.

In previous chapters, the two cores have been depicted as a solid rod and a solid ball. ${ }^{82}$ Yet the axial core, the text of Scripture, is to be received by faithful believers as a dynamic divine communication with transforming power. How can a work of inert writing change a human being? Ricoeur's answer to this problem elucidated three levels of relations between the text and the interpreter in hermeneutics. First, an interpreter can perceive the text as a unique work ${ }^{83}$ with its own internal structure and relations- - this was the main focus of the micro-hermeneutical analysis. Second, a text can be related to the community of other literary works ${ }^{84}$ - this was the main focus of meso-hermeneutical analysis. Third, a text can be restored to a form of speech, as a "living communication" which "opens out onto other things" if it is appropriated by the self in self-

\footnotetext{
${ }^{82}$ This agrees with Ricoeur's definition of an objective text as "any discourse fixed by writing" and the obvious fact that the interpreter is a physical human being. Ricoeur, "What is a Text?" 145.

${ }^{83}$ Ricoeur takes this first depiction to an extreme, saying "We can, as readers, remain in suspense of the text, treating it as a worldless and authorless object." Ricoeur, "What is a Text?" 152. In narrative biblical micro-hermeneutics this is not the case as exegetes carefully attempt to reconstruct the historical, personal and linguistic world of the narrator of the text in order to understand the text's internal logic and relations more accurately.

84 "This relation of text to text, within the effacement of the world about which we speak, engenders the quasi-world of texts or literature." Ricoeur, "What is a Text?" 149. In biblical mesohermeneutics, the community of texts that constitute the canon were primary resources and life experiences provided intuitive patterns for personal immersion into the text.
} 
understanding ${ }^{85}$ - this is the focus of this current chapter on macro-hermeneutics. Ricoeur tags this level as the place where "hermeneutics and reflective philosophy are correlative and reciprocal. ${ }^{96}$ In the appropriation of a text, the reader-interpreter voluntarily overcomes a natural "estrangement from the system of values upon which the text is based" and allows the fusion of "textual interpretation with self-interpretation." ${ }^{87}$ This is how semiotics becomes semantics for the hearer and symbol becomes speech again. ${ }^{88}$

This means the appropriating interpreter may feel confronted by the biblical text and at times, even surgically splayed. The writer of Hebrews proclaims, "The word of God is living and active, sharper than any two-edged sword, piercing to the division of soul and of spirit, of joints and of marrow, and discerning the thoughts and intentions of the heart." ${ }^{99}$ Yet, Scripture's ability to provide deeper self-understanding through disclosure is one of the prized rewards the hermeneuticist seeks in coming to the text.

If the interpreter is on one side of the text as a receiver, what is on the other side of the text? A word implies a speaker, and life must exist on both sides of language for it

${ }^{85}$ Ricoeur, "What is a Text?" $152,158,159$.

${ }^{86}$ Ricoeur, "What is a Text?" 158 . Gadamer, as we have previously noted, believes appropriation does and must mark every level of the interpretive process especially when studying legal or religious texts that have proscriptive intent. Ricoeur's residual symbolic meaning is the final product of his interpretive arc, he tags appropriation to the last step because symbolic meaning is eminently transferable.

${ }^{87}$ Ricoeur, "What is a Text?" 159 . This does not mean that the interpreter will necessarily meld and become aligned to the text, but that true understanding requires authentic engagement, evaluation, insight, and response.

${ }^{88}$ Ricoeur, "What is a Text?" 159. In Ricoeur's discussion this dynamic can be true of any text.

${ }^{89} \mathrm{Heb} 4: 12$. Luther saw the Word of God "not merely a written word belonging to the past, but a viva vox evangelii, a word of God which encounters us here and now." Anthony Thiselton, The Two 
to mean anything. God is taken as the originating source of the message and "no creature is hidden from his sight, but all are naked and exposed to the eyes of him to whom we must give account.. ${ }^{90}$ When self-appropriation of the text calls the interpreter to be responsible to the ultimate source of the text, the arc of responsive transformation in the creature is complete.

Since God is on the other side of the biblical text, the axial core of the hermeneutical spiral ramp is more accurately a filled straw (see figure 5.1 below), a straw of the delicate web of human language (in another figure of speech) wrapped lightly around non-corporeal Divinity. Human language becomes God's chamber. ${ }^{91}$ Scripture attests that God deputized humans ${ }^{92}$ to write under divine inspiration (even what they did not fully understand ${ }^{93}$ ) and God inspired the believing community through the Holy Spirit

\section{Horizons, 100.}

${ }^{90} \mathrm{Heb} 4: 13$. What the Bible attests to is that God sees us even when we do not see him, but what we can perceive is His word, we can hear him through the biblical text and other channels. "God sees me, he looks into me in secret, but I don't see him, I don't see him see me, even though he sees me facing me and not like an analyst on whom I will have turned my back. Since I don't see him see me, I can, or must, only hear him. But most often I have to be led to hear him, by insinuation [on doit me le donner á entendre], I hear tell or hear my self say what he says through the voice of another, another other, a messenger, an angel, a prophet, a messiah, or a postman, a bearer of tidings, an evangelist, an intermediary who speaks between God and myself. ... God looks at me and I don't see him, and it is on the basis of this gaze that singles me out [ce regard qui me regarde] that my responsibility comes into being." Jacques Derrida, The Gift of Death, 91.

91 "Language is the house of Being." Martin Heidegger, "Letter on Humanism," Basic Writings, ed. D. F. Krell (London, UK: Routledge, 1978), 217.

92 "Knowing this first of all, that no prophecy of Scripture comes from someone's own interpretation. For no prophecy was ever produced by the will of man, but men spoke from God as they were carried along by the Holy Spirit." 2 Pet 1:20-21.

931 Pet $1: 10-12$. 
to ascribe Scripture's meaning to God, thereby receiving it as speech from Him addressed directly to them. All believers are thus appropriating interpreters.

The second core of the Axial model is the core of the interpreter. Genesis describes human beings as compositions of dust and divine breath, relapsing back to dust upon death. ${ }^{94}$ The biblical connotation of a fragile constellation of material (dust) held together by divine immaterial life-force (breath) corresponds to Kintsch's ConstructiveIntegration Model, ${ }^{95}$ (see figure 5.1 below). In Kintsch's Constructive-Integration Model a dynamic network of interconnected nodes of knowledge in the human mind works by being either activated or dampened by the semantics of a text. Then, a construct model is built from the activated nodes utilizing inferences from the interpreter's personal experience. Finally, the construct model is then integrated into a mental situation model or symbols which can be recalled as memory. The core of the interpreter can be depicted as a three-dimensional web of responsive knowledge nodes, held together by God's

${ }^{94}$ Gen 3:19.

${ }^{95}$ Walter Kintsch and Teun A. van Dijk, "Toward a Model of Text Comprehension and Production" Psychological Review 55, no. 5 (Sept 1978): 363-394; Walter Kintsch, "The Role of Knowledge in Discourse Comprehension: A Construction-Integration Model" Psychological Review 95, no. 2 (1988): 163-182; Allan M. Collins, "A Spreading-Activation Theory of Semantic Processing" Psychological Review 82, no. 6 (1975): 407-428. 
breath of life, that forges internal models of reality from the fusion of horizons at its periphery.

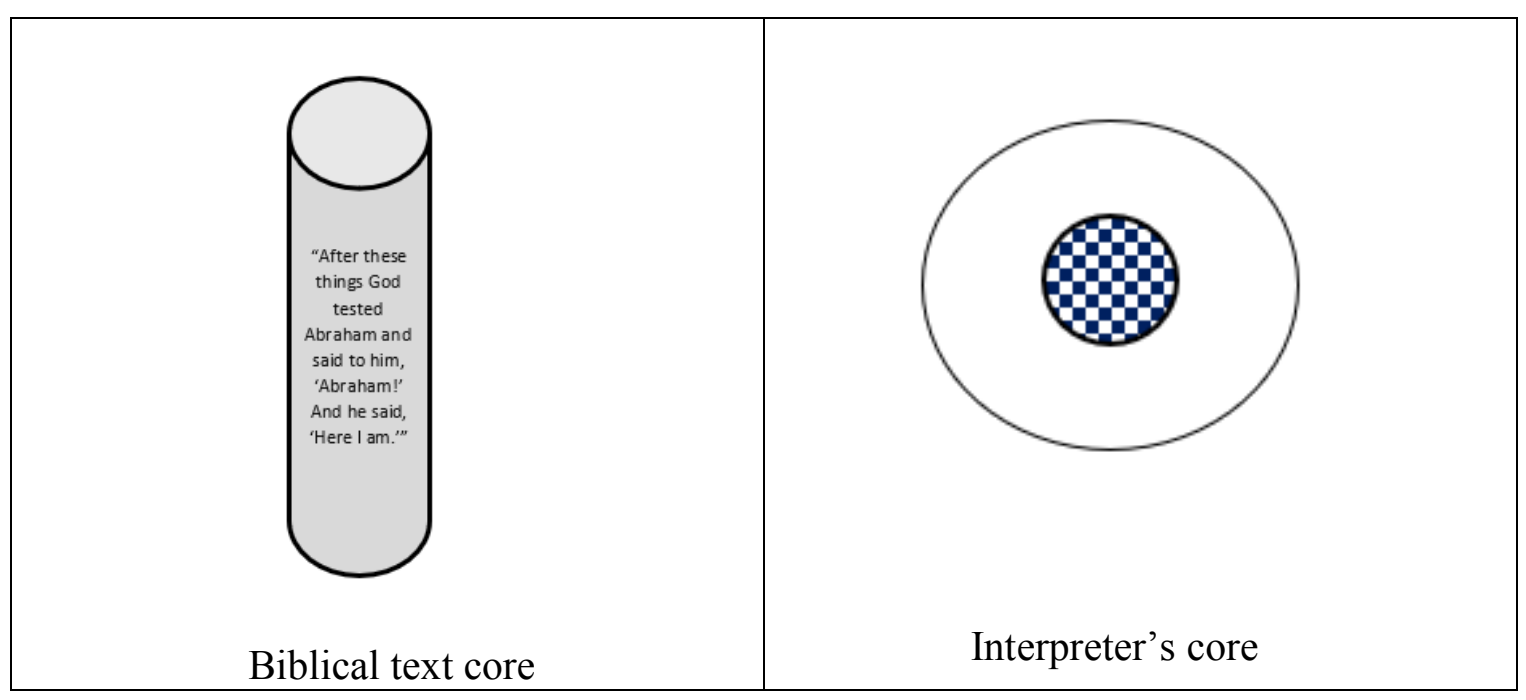

Fig. 5.1 Two Cores of Axial Model. Biblical text core is human language wrapped around God like a straw and the interpreter's core is a network of knowledge nodes.

Now that the cores have been depicted, how do the cores relate to each other? In order to be internally consistent, the relations on the macro-hermeneutical level of the Axial Model must remain just as faithful to the revelations of the biblical text as the previous two levels of micro and meso-hermeneutics have been.

Ontologically, the axial core of the spiral is divine, eternal, and self-sustaining even though it is figuratively wrapped in human language that has a temporal telos. ${ }^{96}$

96 "For truly, I say to you, until heaven and earth pass away, not an iota, not a dot, will pass from the Law until all is accomplished." Matt 5:18. The text has a fulfillment, a telos, but the center of the biblical text is eternal. 
Ontologically, the interpreter's core is a dynamic and unstable mixture of material held together by divine breath—-because he maintains me in existence, God confers on the certainty of myself the permanence that it does not hold in itself." ${ }^{97}$ Thus, if the Genesis account of human creation and the transformation of Abraham through his covenant journey can be taken as analogous processes, the ontological relation between the cores remains a unidirectional flow of created and re-creating life force from the eternal selfsustaining source, God, to the contingent creature, the human being, who beomes fully actualized through openess to God.

Epistemologically, Paul describes human knowledge as a mirror that is not yet fully transparent but will someday be so. In 1 Cor 13:12 he writes, "For now we see in a mirror dimly, but then face to face. Now I know in part; then I shall know fully, even as I have been fully known." This biblical metaphor about knowledge is analogous to a one way mirror. ${ }^{98}$ Since to recognize something as intelligible, the interpreter must use interpretive patterns to try to decode the meaning of the text, ${ }^{99}$ the biblical text predominantly interprets the reader to themselves, while offering only as much of God as

${ }^{97}$ Ricoeur, Oneself as Another, 9. Ricoeur attributes this line of thinking to Descartes.

${ }^{98}$ A one-way mirror (confusingly also called a two-way mirror) is a piece of glass that is reflective on one side and transparent on the other. Usually, the reflective side is better illuminated so the reflective effect is strong, and the mirror's transparent properties are minimized. The ratio of lighting between the two sides of the glass affects whether the reflective or transparent properties predominate. "Mirror" in How It Works: Science and Technology, $3^{\text {rd }}$ ed., vol. 11 (Tarrytown, NY: Marshall Cavendish, 2003), 1463-1464.

99 The crucial role of interpretive patterns for human understanding was discussed in the Theory and Method subsection of Understanding in Chapter 4: Meso-hermeneutics. This does not mean that meaning is necessarily determined by interpretive patterns for such patterns can be modified and changed by their encounter with the text. 
the human comprehension can handle without being overwhelmed. But someday, as Paul anticipates, direct knowledge will be accessible.

Axiologically, the Bible works as a magnifying lens ${ }^{100}$ that magnifies details of God's character-based actions and engraves ${ }^{101}$ the holiness and glory of God's character into the emotive-core of the interpreter. The Holy Spirit can tenderize and render the interpreter inscribable: "And I will give them one heart, and a new spirit I will put within them. I will remove the heart of stone from their flesh and give them a heart of flesh." 102 By appropriating as commanded, "You shall therefore lay up these words of mine in your heart and in your soul," 103 believers will start to reflect God's character. To this end Paul urges believers "to put off your old self, which belongs to your former manner of life and is corrupt through deceitful desires, and to be renewed in the spirit of your minds, and to put on the new self, created after the likeness of God in true righteousness and

${ }^{100}$ A magnifying glass is a convex lens (converging) that makes things look larger if viewed through them and concentrates parallel light toward a focal pinpoint with increased heat. If this focal concentration is held to the surface of an object, the heat produced may burn or inscribe into it. David Krashkevich and Susan R. Loehr, "Ophthalmic Glasses" in The Properties of Optical Glass (New York, NY: Springer, 1998), 263-270. This concept of inscription is being used here metaphorically, where the Holy Spirit channels the power of God's word to change the heart of the reader.

101 The engraving of moral divine law on the heart is a well-known biblical metaphor. "For this is the covenant that I will make with the house of Israel after those days, declares the Lord: I will put my law within them, and I will write it on their hearts. And I will be their God, and they shall be my people." Jer $31: 33$.

${ }^{102}$ Ezek 11:19; 36:26.

${ }^{103}$ It continues, "and you shall bind them as a sign on your hand, and they shall be as frontlets between your eyes.” Deut 11:18. 
holiness." ${ }^{104}$ These ontological, epistemological and axiological hermeneutics necessitate a hermeneutical methodology of philosophy.

\section{Macro-Hermeneutical Methodology}

Ontology, epistemology, and axiology, comprise the Y-axis ${ }^{105}$ of both cores and refers to the world of meaning above and below the origin, the metaphysical assumptions about ultimate reality and the fundamental nature of the cosmos. Because the Y-axis is the conceptual lens ${ }^{106}$ of the biblical text and of the interpreter, a hermeneutical

${ }^{104}$ Eph 4:22-24.

${ }^{105}$ The $\mathrm{Y}$-axis was first described relative to the $\mathrm{Z}$ and $\mathrm{X}$ axes in the subsection "A Model Hermeneutic" near the beginning of Chapter 3: Micro-Hermeneutics, see pages 70-74.

${ }^{106}$ Conceptual lens refers to the mental framework or paradigm at the most basic level of understanding. Historically, the term philosophy referred to rational, critical thought with claims to universal validity while worldview had a more personal and historically relative connotation in reference to a point of view. There are several ways that these two concepts can be related to each other; I am partial to the one that treats philosophy as the rational distillation or yield from the ground of a personal worldview that accepts Scripture as foundational. See Albert M. Wolters, "On the Idea of Worldview and its Relation to Philosophy" in Stained Glass: Worldviews and Social Science, eds. Paul A Marshall, Sander Griffioen, Richard J. Mouw (Lanham, MD: University Press of American, 1989), 14-25. 
methodology is needed that that expedites re-calibration of the interpreter's conceptual lens (Y-axis) by the text's conceptual lens (Y-axis). ${ }^{107}$

The methodology for hermeneutical philosophy is not synonymous with the methodology for traditional philosophy. My understanding of Anthony Thiselton's three methodological shifts of hermeneutical philosophy ${ }^{108}$ follows.

1. The epistemological flow is not exclusively understood as from the reader to the text but also from the text to the human inquirer, who, in understanding the subject matter, sees their previous pre-understanding of the subject matter challenged, and by extension - themselves as interpreted by the text. ${ }^{109}$ This kind of engagement can only result from intentional appropriation. ${ }^{110}$

2. Traditional philosophy focuses on abstract problems which have been extracted from their origin in human situations, but hermeneutical philosophy explores those “"questions that arise' within a chain of question-and-answer that reflects concrete

\footnotetext{
107 "The categories in which the Biblical man conceived of God, man, and the world are so different from the presuppositions of metaphysics upon which most of Western philosophy is based that certain insights that are meaningful within the Biblical mind seem to be meaningless to the Greek mind. It would be an achievement of the first magnitude to reconstruct the peculiar nature of Biblical thinking and to spell out its divergence from all other types of thinking. It would open new perspectives for the understanding of moral, social and religious issues and enrich the whole of our thinking. Biblical thinking may have a part to play in shaping our philosophical views about the world." Heschel, God in Search of Man (New York, NY: Farrar, Status and Giroux, 1083), 23 note 8.

108 Thiselton, Hermeneutics, 7-12.

109 "The truth has us ourselves as its object." Ernst Fuchs, "The Hermeneutical Problem" in The Future of our Religious Past. Essays in Honour of Rudolf Bultmann, ed. J. M. Robinson, (London, UK: SCM Press, 1971), 267-278. T. F. Torrance believed "the key to the interpretation of a text, whether of Plato or of St. Paul, is self-understanding." Torrance quoted by Thiselton in The Two Horizons, 106.

${ }^{110}$ Again, "the texts must translate us before we can translate them." Fuchs, "The Hermeneutical Problem," 277.
} 
situations in human life." To achieve this, Gadamer suggests careful reflection on the hermeneutical experience can transform philosophical abstract problems back into their germinal situational questions. ${ }^{111}$

3. Traditional philosophy aims for factual certainty in knowledge using Descartes's method of the autonomous individual wielding radical doubt upon the object of study; a practitioner of hermeneutical philosophy recognizes the inherited understanding of their community as an unavoidable starting point for uncovering the provisional meaning of the study matter which reflexively interprets the interpreting self and community.

The following discussions arise from applying the hermeneutical methodology to the metaphysical world of meaning in the first verse of the Aqedah. ${ }^{112}$ The conversation will unpack the first verse of the Aqedah ontologically, epistemologically, and axiologically to follow those lines of thought as "opened up by the text." ${ }^{113}$ As the reader

\footnotetext{
111 "Reflection on hermeneutical experience transforms problems back to questions that arise and that derive their source from this motivation." Gadamer, Truth and Method, 377. Collingwood wrote that truth belongs "not to any single proposition, nor even ... to a complex of propositions taken together; but to a complex of questions and answers." Collingwood quoted by Thiselton, The Two Horizons, 309.

${ }^{112}$ Due to space limitations all nineteen verses of the Aqedah cannot be handled this way.

${ }^{113}$ Ricoeur, "What is a Text?" 162.
} 
will soon see, one verse is more than enough to initiate the reader into the worlds of meaning above and below the Aqedah text.

\section{Ontology of the Aqedah Event}

The first verse starts with (lit.)“After these things, it happened.” From microhermeneutical exegesis we know this phrase is an idiom of speech which bookends the Aqedah (Gen 22:1, 20). As a grammatical idiom, it would be imprudent to dissect it minutely for philosophical insight. But the referential meaning of the phrase must be questioned. What exactly are these things ${ }^{114}$ Inferring from its context, it seems to refer to previous events. ${ }^{115}$ Events are unitary clusters of entities, speech and actions in the shared common world. This initial hunch is corroborated later (Gen. 22:16) where God refers to Abraham's test responses as one thing, "because you have done this thing ..." This test event - "this thing"- is to be added to the previous events of Abraham's life, referred to previously as "these things." 116 They are aligned linguistically. Because this idiom envelopes the Aqedah event, if the previous stories about Ishmael and the purchase

\footnotetext{
${ }^{114}$ In Hebrew, the root term dābār can refer to things, matter, or words, depending on its context. Scholars have shown that it is false to claim a "close relationship between the vocabulary grids and morphological and syntactical structures of a language, on the one hand, and the thought structure and apprehension of reality of the users of language, on the other." It is wiser to recognize language meaning from their functions within the "given tradition of language-uses" or, as Wittgenstein calls them, language games. Anthony Thiselton, The Two Horizons, 134-5. A cautionary debunking of the attempt to glean philosophical insight about Hebrew thought from the etymology alone of $d \bar{a} b \bar{a} r$ is provided by James Barr, The Semantics of Biblical Language, 129-140. Here, I am staying within synchronic functionality for extracting ontological presuppositions.

115 Abimelech also refers to Abraham's deception as a thing (Gen 20:11).

116 Only the passage of time can distinguish whether an experienced event turns out to a dream, a vision or actual reality. Meaning is context-dependent, but significance relies on criteria which requires some historical distance to apply appropriately. Thiselton, The Two Horizons, 74.
} 
of a burial site in Hittite territory are accepted as historical facts in our same shared

world, the narrator is placing the Aqedah event in the same category. ${ }^{117}$ Thus the

perlocutionary force of the idiom, "after these things, it happened" is that the events

flanking the phrase are to be taken as ontologically equivalent. ${ }^{118}$

But even in our shared world, people can have consciously altered experiences.

For instance, a dissociative fugue ${ }^{119}$ is a psychogenic event where a fully conscious

person embarks on unplanned travel due to an altered symbolic state of mind about their

identity and exhibits amnesia post-recovery. Could the Aqedah be a dissociative fugue of

Abraham? Since there are no directly accessible traces or artifacts from that event outside

the biblical text, the reader is left addressing this question to the text. The narrator's

117 The appeal to personal experience as evidence for religious reality is not self-authenticating or decisive, but the conceptual scheme which this experience fits into, is what provides the comparative basis for rational belief. "A numinous experience, for example, justifies God exists only if E justifies the basic conceptual (or some conceptual) setting in which 'God' is referential and God exists an essential tenet. A conceptual scheme, I take it, is (roughly) a set of propositions relevant to explaining or interpreting a range of data, solving (or dissolving) a set of problems, or articulating a view of what there is." Keith E. Yandell, “Religious Experience and Rational Appraisal," Religious Studies 10 (May 1974): 185.

118 Due to the assumption of truth in communication, when a story is read it is initially presumed to be factual until linguistic details appear which jar against our actual experience of the world. Only then do we project upon the text paradigms of fables, legend, or fiction to see what linguistic framework the text best fits into. This means the worldview of the reader (naturalistic or theistic) and the literary paradigms they are familiar with (literary genres) are the initial lens brought to the text.

${ }^{119}$ A dissociative fugue is a rare and limited psychogenic state where there is a sudden unexpected travel away from home or work that lasts hours, days or even months with a change of identity during it and associative amnesia post-recovery. The patient is conscious and highly purposeful during the trip unlike the confused aimless wandering that is associated with other forms of amnesia. The patient often assumes a different identity (partial or total) usually with symbolic value. As to the cause, "It is likely that family dynamics play a large role psychologically in its instigation." Medical Factors and Psychological Disorders: A Handbook for Psychologists, eds. Alan S. Bellack and R. L. Morrison (New York: Plenum Press, 1987), 125; Donald W. Black and Jon E. Grant, DSM-5 Guidebook: The Essential Companion to the Diagnostic and Statistical Manual (Washington, D.C.: American Psychiatric Publishing, 2014), 195. 
attestation $^{120}$ doesn't qualify it as altered consciousness ${ }^{121}$ but relates the plot in a matterof-fact manner: "God tested Abraham." Narrative testimony does not match the level of Cartesian verifiable proof, but as with any claim for a unique occurrence in history, the way to ascertain factuality is to analyze the testimony itself or compare conflicting testimonies. ${ }^{122}$ At this juncture the reader faces an either/or quandary on whether to trust the everyday ordinary manner of the narrator's personal testimony ${ }^{123}$ or to dismiss it.

Because the hermeneutical approach is to listen receptively, suspending judgment until the end, ${ }^{124}$ a reader may search within the text for any externally referenced evidence for the Aqedah as a credible event. The metalepsis of Gen 22:14 claims the Aqedah event

${ }^{120}$ Attestation is the kind of certainty expressed by "I believe in ..." For example, a criterion of truth can be confidence in a testimony, "I believe in the explanation of the narrator of the Aqedah until I find reasons not to." This is a level of mediated credence between absolute certainty as asserted by the Cartesian cogito and the shattered cogito of Nietzsche's suspicion that sees all facts as unreliable private interpretations. Paul Ricoeur, Oneself as Another, 13-15.

121 The Genesis narrator is capable of distinguishing and relating to the reader different mental conditions of previous divine revelations. Abraham heard and saw God (Gen 12:1,7; 17:1), had visions (Gen 15:1), experienced deep sleep or trances (Gen 15:12). Abimelech conversed with God in a dream (Gen 20:3). It is implied by the timing of Abraham arising early in the morning after the communication, that the test command of Gen 22:2 came to him during the night, though the modality (dream, vision, thought, auditory speech, etc.) isn't specified in this case. The ensuing Aqedah journey to the mountain is relayed through concrete everyday-like details.

${ }^{122}$ It is too narrow-minded to accept as historically fact only those recorded events homologous to our personal experience, this would classify most literature of other historical eras and cultures as fiction. Facts are recognized by context and that context includes "thoughts," "theology," "cultural outlook," and "the historical events which surround them." Thiselton, The Two Horizons, 80.

${ }^{123}$ Ricoeur discriminatingly illuminates that a personal testimony does not appeal to the criteria of verifiability but submits to a question of veracity. In other words, is the speaker or source attested to be trustworthy based on previous interactions? Ricoeur, Oneself as Another, 72.

124 The strategy of holding judgment until the end of the story was fruitful for the micro and mesohermeneutical levels, for it was the ending of the Aqedah that provided the key to the rest. The hermeneutical stance is to avoid premature conclusions in order to allow honest open dialog between the personal and biblical worlds of meaning as normed by the whole text. 
was the cause for a known proverb in the narrator's own time, long after the original event. This community confession is independently verifiable by his readers for he appeals to their recognition of it, "as it is said to this day, 'On the mount of the Lord it shall be provided"' (Gen 22:14). Widespread external credence buttresses the internal testimony that the Aqedah was accepted as a legitimate historical event by the community at large. In addition, the community proverb implies the Aqedah experience awaits anyone willing go up to the mountain of the Lord.

This assertion of an ontological event satisfies Wolfhart Pannenberg's claim that singular historical events believed to be "divine intervention in this-worldly events" are "fundamental to every religious understanding of the world." 125 Pannenberg embraces the historical particularity of such events as a positive for religion, because "what is historically unique is as far as anything possibly can be from myth." ${ }^{126}$ Well attested events and words intertwined together become the embryonic nidus of religious traditions. As such religious traditions mature, they function like Wittgenstein's

\footnotetext{
${ }^{125}$ Pannenberg cited by Thiselton, The Two Horizons, 81-82.

${ }^{126}$ Pannenberg cited by Thiselton, The Two Horizons, 81-82.
} 
language-games, a conceptual system that makes sense of its own parts, self-critiques inconsistencies, and judges new phenomenon for authenticity and orthodoxy. ${ }^{127}$

\section{Ontology of God}

Divine events of self-revelation anchor accurate and correct understanding of God, which is one of the goals of religious philosophy. Abraham Heschel carefully lays out, "The religious situation precedes the religious conception, and it would be a false abstraction for example to deal with the idea of God regardless of the situation in which such an idea occurs. Our first goal, then, is not to evolve the philosophy of a doctrine, interpretations of a dogma, but the philosophy of concrete events, acts, insights, of that which is a part of the man." ${ }^{28}$ In fact, the fundamental theology of the Old Testament "goes directly back to 'the fathers,' springing full-blown as it were from them" for the theology of the patriarchs was largely inferential - not speculative. ${ }^{129}$

\section{"After these things"}

It comes as no surprise that the first phrase of the Aqedah, "After these things" (v. 1) refers the reader to the shared history ${ }^{130}$ of Abraham and God. Memory is the "recipe"

\footnotetext{
127 Thiselton, The Two Horizons, 81.
}

${ }^{128}$ Heschel, God in Search of Man, 7.

${ }^{129}$ John N. Oswalt, "Abraham's Experience of Yahweh: an Argument for the Historicity of the Patriarchal Narratives" in Perspectives on Our Father Abraham: Essays in Honor of Marvin R. Wilson, ed. Steven A. Hunt (Grand Rapids, MI: Eerdmans, 2010), 34.

130 "The veracity of what Confucius, or Buddha, or Muhammad taught about the nature of reality has nothing to do with whether those persons actually lived or not. . . the teachings are entirely independent of whatever those formative experiences may have been or may have not been. But that is not so with Abraham. His experiences are the religious teachings of Genesis 12-24 and everything that follows 
for identity. ${ }^{131}$ In terms of identity, the Abrahamic narratives offer almost no physical description about God or Abraham, even though we are told God incarnated and assumed human form and ate a homemade meal from Abraham (Gen 18). What is given instead in Genesis is an abundance of divine communication and deeds.

If an ontological philosophy of God ought to be grounded in God's self-revelatory events, the nature of that self-revelation should direct the inquiry. Since divine selfrevelations in the Abrahamic narratives are predominantly divine words and deeds, ${ }^{132}$ identity questions of "who" is doing the creating, speaking, promising and testing, inferred from historical actions ${ }^{133}$ will be more fruitful than questions on "what" is God's essence or substance, which necessitates descriptive explanations. Thus the Abrahamic cycle provides a functional profile of who God is. From the initial call to leave Haran

that block of material is dependent on it." John N. Oswalt, "Abraham's Experience of Yahweh," 34.

${ }^{131}$ Paul Ricoeur, Memory, History, Forgetting, trans. Kathleen Blamey and David Pellauer (Chicago, IL: University of Chicago Press, 2006), 81.

${ }^{132}$ One of the clearest biblical instances of divine self-revelation was a verbal proclamation about the moral, functional aspects of Himself. See Exod 34:5-7.

${ }^{133}$ Ricoeur, Oneself as Another, 143. 
(Gen 12:1-3) to the final provision of the ram in the Aqedah (Gen 22:13), God's actions are those of a concrete promise-maker and promise-keeper for Abraham. ${ }^{134}$

Without ignoring the larger picture of God as provided by the Christian canon, it is instructive to highlight the regional ${ }^{135}$ characteristics of divine ontology grounded in the Abrahamic narratives. The "necessary and self-existent being which is the God of the philosophers" communicated to Abraham multiple times, relating directly to him in a temporal, personal, powerful, yet everyday-like manner ${ }^{136}$ that built up trust. Unlike the philosophers who speculate about God as a possibility, Abraham's story started with a

\footnotetext{
${ }^{134}$ It is interesting that God's initial promises to Abraham were, in John Oswalt's opinion, "neither spiritual nor transcendent. They were almost crushingly mundane, a baby, a homeland, a reputation (Gen. 12:1-3). There is nothing 'religious' here at all. There is no forgiveness of sin, or of special favor with the divine, no promise of a blissful after life. Nor is this promise made only once. As the narrative continues, those promises are repeated in one way or another seven more times." John N. Oswalt, "Abraham's Experience of Yahweh," 34. Bollnow systematized this approach in his pedagogical anthropology as "appealing pedagogy," a way to teach "which directly appeals to the aspirations of the human being." Jani Koskela, "Discontinuity as Foundation to Pedagogy" (PhD dissertation, University of Oulu, Finland, 2012), 46, accessed June 22, 2019, http://jultika.oulu.fi/files/isbn9789514298769pdf.

${ }^{135}$ This term regional is used here to describe the localized, specific scope of divine ontology limited to what is expressed in the Abrahamic narratives. Husserl differentiated between formal and regional ontology, regional referring to cognitive partitions of the whole. "Regional or material ontologies are synthetic a priori disciplines about particular regions of objects. Each region is constituted in one way or another in accordance with consciousness and thus delineates in advance (a priori) our modes of access to it (or, equivalently, its manner of presenting itself to scientific scrutiny). On this material or regional level, then, Husserl's working hypothesis is that of an ontological pluralist." Daniel O. Dahlstrom, "Hermeneutic Ontology," Theory and Applications of Ontology: Philosophical Perspectives, eds. R. Poli, J. Sebt (New York: Springer, 2010), 397; see also Boris Hennig, "What is Formal Ontology?" (Heusenstamm, BRD: Ontos Verlag, 2008), 46, in Applied Ontology: An Introduction, accessed 31 March 2019, https://pdfs.semanticscholar.org/90d2/d70dc86b2820d5e49c8aa54e38af67f66fbd.pdf.

${ }^{136}$ Keith Ward continues with the paradox: "After all, the One who is said to have walked and talked as a person with Abraham is also the one whom no man can see and live and of whom no image can be made." Keith Ward, "The God of the Philosophers and the God of Abraham, Isaac, and Jacob," The Journal of Jewish Thought and Philosophy 8 (1999): 169.
} 
phenomenological confrontation of "overwhelming reality"137 that voiced Abraham's deepest hidden wishes. Through history, philosophical concepts of God have continuously morphed, from first cause or True Being, to infinity, then to Being itself, ${ }^{138}$ but for Abraham, God remained an interactive personal deity throughout his lifetime.

The first time Abraham described his personal God to others, it was as Lord, God Most High, Possessor of Heaven and Earth (Gen 14:22). This evokes themes from the beginning of Genesis where God is the relational Creator of a good creation, including humans. ${ }^{139}$ Creation and the Abrahamic narratives share interesting parallels. In Genesis 1-2, God created the physical world and all its inhabitants through His word, evaluated Adam and Eve as very good, then allowed them to be tested (Gen 3). At the end of their failed test God assessed them and made a covenant of redemption with humankind (Gen 3:8-19). In the Abrahamic narratives, God creates a unique covenant partner, forging the identity of Abraham out of Abram through divine promises culminating in Isaac. Then, according to the Covenant Hypothesis, God tests Abraham to assess the degree of covenant integration in Abraham's character which also ends with a divine assessment and re-establishment of the divine covenant (Gen 22:15-18). The divine assessment

${ }^{137}$ Ward, "The God of the Philosophers," 157.

${ }^{138}$ Wolfhart Pannenberg, "God of the Philosophers," First Things, (June 2007), accessed 4 March 2019, https://www.firstthings.com/article/2007/06/002-god-of-the-philosophers.

139 “Creativeness comes before law, guilt, and even redemption . . . as radical as evil may be, it will never be more originary than goodness, which is the Ursprung in the field of ethics; the orientation to the good as being rooted in the structure of the human being, or in biblical terms: creation, created." Paul Ricoeur and Contemporary Moral Thought, eds. John Wall, William Schweiker, and W. David Hall (New York: Routledge, 2002), 283. 
evokes the triumphant Seed of the Woman motif first encountered in Genesis 3:15 by the phrase "Your Seed shall possess the gates of his enemies" (Gen 22:18). ${ }^{140}$ The identity of God is recognized in the consistency of His actions and promises that link different events.

What does a promise-maker/keeper accomplish? A promise-maker stabilizes an uncertain future in time by commiting themselves in a specifically reliable way or action to others. This carries ontological, epistemological and axiological implications. Ricoeur spells out what this role means through the ontology of identity in relation to time, “Keeping one's promise, as was mentioned above, does indeed appear to stand as a challenge to time, a denial of change; even if my desire were to change, even if I were to change my opinion or my inclination, 'I will hold firm." ${ }^{141}$ Epistemically, the promisekeeper crystallizes assumed generalized expectations into definite verbal pledges.

Ethically, a promise-keeper upholds ethical notions of communication truthfulness and fidelity to deposited confidence, in other words, they try to "safeguard the institution of

\footnotetext{
${ }^{140}$ An examination of whether the seven covenant epiphanies of Abraham have any relation to the seven days of creation would be an interesting future study.

${ }^{141}$ Ricoeur, Oneself as Another, 124.
} 
language" itself which is usually taken to be truthful at face value for they "respond to the trust that the other places in [their] faithfulness." 142

\section{“God tested Abraham"}

From what has just been explicated above, it now becomes startlingly clear that in issuing the test command to offer Isaac as a burnt offering, God jeopardized God's own identity as a promise-keeper. Before Abraham risked his reputation as a father, before Isaac risked his life on the altar, God risked His own moral reputation, the foundation of faith for salvation, by commanding human sacrifice. The long-term magnitude of this risk cannot be fully measured but it has been devastating. ${ }^{143}$ As the divine Tester, God risked losing not just Abraham to whom this test was directed but all the ensuing generations of readers who read this recorded account but don't have an immediate Abraham-like experience with God to fall back on. Why does God risk His moral reputation when consistency in promise-makers is absolutely necessary for human trust?

The why question sends the readers to search the text for a test purpose valuable enough to rationally offset the magnitude of divine risk. If the term of affection in v.2 "whom you love" is assumed to be the purpose for the test, then God's need for undiluted

\footnotetext{
${ }^{142}$ Ricoeur, Oneself as Another, 124. Of the two main speakers in the Aqedah, God is more trustworthy in truthfulness.

${ }^{143}$ Many have pointed to God's role in the Aqedah as a reason for their rejection of the God of the Bible. Among them are Richard Dawkins, The God Delusion (Boston, MA: Houghton Mifflin, 2006), 242; Christopher Hitchens, God is Not Great: How Religion Poisons Everything (New York, NY: Hachette Book Group, 2007), 51, 53, 207, and Carol Delaney who poignantly inquires, "Why is the willingness to sacrifice the child, rather than the passionate protection of the child, at the foundation of faith?" at the conclusion of her book Abraham on Trial (Princeton, NJ: Princeton University Press, 1998), 252-253.
} 
affection is worth appearing jealous and self-centered. If the test conclusion is taken to be v. 12, then Abraham's obedience or "Fear of God" is worth the risk of sounding like Baal and Molech in demanding child sacrifice. If the answer is the substitionary ram as the symbolic meaning for the test, then the banishment of child sacrifice or demonstrating a typology for the crucifixion is pedagogically worth the risk of emotional trauma and of God appearing to be blood-thirsty. The Covenant Hypothesis does not stop at any of these way stations ${ }^{144}$ but extends the search to God's final words (vv. 16-18).

God's final speech bears the all the logical earmarks of a valid test evaluation: a credible test evaluation comes from the test's Tester ("By myself I swear, says the Lord"), refers to the test performance of the testee ("because you have done this thing"), allocates credit in a specific manner (six covenant themes and blessings) relative to a norm previously accessible to the testee (seven covenant epiphanies), and ends with summary judgment ("because you obeyed My voice"). From all of this, it appears that covenant-defined ${ }^{145}$ character is the real reason for the test - of both divine and human entities. The Aqedah assessed Abraham's character in a manner that leads us to assesses God's character. ${ }^{146}$ The test imposed a challenge which risked Abraham's covenant

${ }^{144}$ A way station is a stopping point within a journey.

145 Outside the moral boundaries of God's covenant relationship, love can slip into manipulation and deception (Abraham convinces Sarah, because of her love for him, to deceive others and be taken away), compliance can breed discord (Abraham complies with Sarah's need for children and control, leading to Hagar's near death), and fear (or the lack of the fear) of God can be used to justify ethnic discrimination (Abimelech is morally disrespected, so lied to). Within the covenant framework, the virtues of love, obedience, fear of God, resurrection, and substitutionary atonement resides ethically.

${ }^{146}$ Some interpretations of the Aqedah point out that when Abraham tries to literally carry out the test command by raising the knife, that action forced God to intervene. Thus, after God tested Abraham, Abraham tested God (v. 10). The Covenant Hypothesis proposes that God risked Himself first through the 
identity and God risked his own covenant identity by issuing it. This was a mutual test with mutual risk.

\section{"and [God] said to him, ‘Abraham.' And he said, 'Here I am."”}

Why did God put Himself at risk first? God chose to act out of character with His own covenant identity in order to elicit from Abraham a redemptive response from his covenant identity. By God's speaking out of character, the meaning of the covenant bond that tied them together could be tested by Abraham's hermeneutical response. But ultimately and redemptively, both the angel and the ram were at hand to save Abraham from slipping into well-intentioned murder. In the Covenant Hypothesis, God's selfsacrifice in two different ways, through the test command and the mature ram, begins and ends the test. In this test God is figuratively the Alpha and Omega, for the essence of the covenant character of God is self-sacrificial love for His creatures, even to the point of putting his moral reputation on the line.

\section{Ontology of Abraham}

\section{"After these things"}

Who, then, is Abraham? Abraham struggled with the most basic fear of humans beings, the fear of death. Abram had been a seventy five year old man dealing with an

test command, laying His own reputation low in order to set Abraham up as the exemplary covenant father, radically different from pious fathers of other gods. However, when Abraham's external actions mimicked those of other idolatrous fathers, God as the Perfect Father stepped in for him and demonstrated the essence of covenant fatherhood by saving Isaac and offering Himself through the representative ram to take Isaac's place. 
infertile wife and a dead end future when God called him to embark on a new journey of life. God's call projected an incredible vision of him in the future as fertile, virile, generative, and a source of worldwide blessings (Gen 12:1-3). In subsequent years, Abram vacillated between fear and faith, his fear of being killed led to the Egypt debacle (Gen 12:12), but he was willing to risk his life to rescue Lot (Gen 14). God commended his martial bravery and tried to cure his paranoia of being killed with a personal prophecy, "As for you, you shall go to your fathers in peace; you shall be buried in a good old age" (Gen 15:15). But even after he was named Abraham with Isaac's birth pending (Gen $17 \&$ 18), Abraham risked losing the covenant son by giving Sarah away during Isaac's gestational year to Abimelech because of Abraham's irrepressible fear of death (Gen 20:11-13). Against this narrative backdrop the Aqedah is surely a limitsituation ${ }^{147}$ crisis for Abraham, a trial that forced him to confront the extreme limits of his fear, hope, life, and meaning for living.

Thus, though religious philosophy is pictured as mankind delving into the problem of God, what is really at stake in the center of that problem is the hidden but much more radical problem of humans. It is not God, but the problem of humanity (fear,

147 A limit situation is a condition where the limits of the human capacity for thinking, understanding, and consciousness is encountered. These kinds of situations may be marked by fear, change in self-awareness, suffering, sense of finitude, death or life decisions. They can also include occasions of sublime joy, peace, wholeness, creation and intense love. Great disintegration or new discoveries of life's purpose or meaning can result. Karl Jaspers originally referred to these encounters as "boundarysituations." Karl Jaspers, Truth and Symbol, trans. Jean T. Wilde, William Kluback, William Kimmel (New York, NY: NCUP, 1956), 10; C. Mundt, “Jaspers Concept of 'Limit Situation': Extensions and Therapeutic Applications," Karl Jaspers' Philosophy and Psychopathology, eds. Fuchs T., Breyer T., Mundt C. (New York, NY: Springer, 2014), 169-178. 
hope, life, meaning) that begs to be solved. Abraham Heschel believed the solution for the human problem could be found in worship:

Man is the problem. His physical and mental reality is beyond dispute; his meaning, his spiritual relevance is a question that cries for an answer. And worship is an answer. For worship is the act of man's relating himself to ultimate meaning. Unless man is capable of entering a relation to ultimate meaning, worship is an illusion. And if worship is meaningless, human existence is an absurdity. ${ }^{148}$

But this prompts the basic question of what is a human being that it needs meaning to flourish? Paul Ricoeur's hermeneutical philosophy of the human subject employed the terms idem (sameness) and ipse (selfhood) ${ }^{149}$ as a way to understand the nature of human identity. Ricoeur's ipse referred to the agent aspect of selfhood that chooses and commits self. Idem was the physical self recognizable throughout life as itself from core character and unique mannerisms. These two concepts correlate with the biblical anthropology in the Abrahamic narratives where the same human being is tagged with two names. Abram correlates with idem, the recognizable physical entity of the main protagonist in these stories. This same sojourner in Canaan is later named Abraham, which correlates with ipse, the struggling, suffering, capable and learning self, who is trying to grow into the God's vision of him ${ }^{150}$ as the covenant father and founder of God's

\footnotetext{
${ }^{148}$ Heschel, God in Search of Man, 119.

${ }^{149}$ Ricoeur, Oneself as Another, 3.

150 The human being has the potential for envisioning a future possible self in the world for a
} desired purpose and then becoming it. "The disclosedness of the there in understanding is itself a mode of the potentiality-of-being of Da-sein. In the projectedness of its being upon the for-the-sake-of-which together with that upon significance (world) lies the disclosedness of being in general. An understanding of being is already anticipated in the projecting upon possibilities." Heidegger, Being and Time, 138. 
elect nation. At some point in the journey, "after these things," it can be assumed that ipse has become the permanent identity recognizable as the new idem, but to what degree? Such a question can only be answered by testing, a test of how Abraham worships that will uncover who Abraham worships.

\section{“God tested Abraham"}

Testing is uncovering the true condition of something otherwise hidden. If the test of the Aqedah is understood through a Heideggerian lens, then God as the Divine Tester becomes the clearing ${ }^{151}$ for the accurate disclosure ${ }^{152}$ of Abraham's authentic self. ${ }^{153}$ Like Ricoeur, Heidegger's concept of beings utilized two concepts. Heidegger's

\footnotetext{
${ }^{151}$ Heidegger attributed the potential to be as a clearing, a site where "objectively present things become accessible in the light or concealed in darkness" as a unique aspect of sentient, self-aware human beings. He wrote, "To say that it is 'illuminated' means that it is cleared in itself $a$ s being-in-the-world, not by another being, but in such a way that it is itself the clearing." Heidegger, Being and Time, 125. Yet, it is through the divine test that Abraham is brought to see himself more clearly - seeing himself through the eyes of God. Prior to the test, Abraham may not have realized to what lengths he would go. Thus, one clearing may require another.

${ }^{152}$ Heidegger used the Greek term $\dot{\alpha} \lambda \dot{\eta} \theta \varepsilon l \alpha$ (alêtheia or disclosure) for the notion of uncovering the truth or making intelligible sense of things as themselves. "The alettheia which is equated by Aristotle with pragma and phainomena in the passages cited above signifies the "things themselves," that which shows itself, beings in the how of their discoveredness. ... What makes this discovering itself possible must necessarily be called 'true' in a still more primordial sense. The existential and ontological foundations of discovering itself first show the most primordial phenomenon of truth." Heidegger, Being and Time, 202-203.

${ }^{153}$ The concept of the authentic self, according to Heidegger, is the opposite of the human that lives in horizontal conformity to society, a state of they-self. "The self of everyday Da-sein is the they-self which we distinguish from the authentic self, the self which has explicitly grasped itself." Heidegger, Being and Time, 121. In addition to differentiating from others, Kierkegaard adds that one's singular vertical relation to God is necessary for Christian authenticity. The Covenant Hypothesis expands the existential trajectory of Kierkegaard regarding Christian authenticity by insisting that absolute singular relation to God must be defined by the whole historical revelation-based covenant walk with God, which opens horizontal and vertical dimensions through time. Otherwise, an ahistorical non-propositional, non-contextual singular and absolute piety could easily mistake Molech as Yahweh and vice versa.
} 
Vorhandenheit (presence-at-hand, of things as they are in themselves) corresponds to Ricoeur's notion of idem (sameness, the same recognizable human entity through time) and Heidegger's concept of Dasein ${ }^{154}$ (self-aware, caring, temporal, interpreting human being) to Ricoeur's notion of ipse (selfhood, the human that relates to itself as an agent). ${ }^{155}$ The self is comprised of both a stable and dynamic identity.

But what holds these two aspects of self together during transformation? Ricoeur recognizes Heidegger's contribution here, "The connection between selfhood and Dasein, in its turn, occurs in Being and Time through the mediation of the notion of care (Sorge), which is the most fundamental existential capable of ensuring the thematic unity of the work." ${ }^{156}$ At a very basic level human beings care, about themselves, their future, their world and what they encounter in the world. ${ }^{157}$ Care does not refer here to an emotional compassion or a feeling of anxious concern, care is meant in a primordial ontological sense as directed personal interest. In addition, when humans believe they possess an unrealized potential related to something that can be taken care of in the real world and catch a vision of themselves accomplishing it, ${ }^{158}$ the underlying human orientation of care Time, 179.

154 "Dasein is a being which is concerned in its being about that being." Heidegger, Being and

${ }^{155}$ Ricoeur, Oneself as Another, 309.

${ }^{156}$ Ricoeur, Oneself as Another, 309.

157 "The formal existential totality of the ontological structural whole of Da-sein must thus be formulated in the following structure: The being of Dasein means being-ahead-of-oneself-already-in (the world) as being-together-with (innerworldly beings encountered). This being fills in the significance of the term care, which is used in a purely ontological and existential way." Heidegger, Being and Time, 180.

${ }^{158}$ God's call in Gen 12:1-3 casts that initial vision for Abram. In Gen 15, Abram's complaint demonstrated that Abram fully appropriated God's vision and was frustrated that God hadn't fulfilled His 
is transformed into willingness. ${ }^{159}$ In Abraham's case, at the beginning of the covenant journey, God came to him and cast a vision of a glorious, incredible future that would change the world by blessing all the families on earth. Abraham was given a dream to care about and it changed him.

\section{"and [God] said to him, 'Abraham.' And he said, 'Here I am.'”}

Thus, Abraham's ready response at the end of the first verse, "Here I am"

(hinneni), is more than a spatial-temporal locator. It evinces an ontological readiness and openness toward God, inviting God to see him and know him for what he is. This hinneni anchors the three apices (vv. 1-2, 7-8, 11-12) of the chiastic literary structure of the Aqedah. ${ }^{160}$ The anchoring of the literary structure by Abraham's consistent response indicates the stance of receptive, self-aware openness to the other is vital for human flourishing.

In summary, God is the ontological source of life and meaning for humans as their creator, re-creator, visionary and promise-keeper, and the ontological role of the

promises yet.

159 "In willing, a being that is understood, that is, projected upon its possibility, is grasped as something to be taken care of or to be brought to its being through concern. . . . If willing is to be possible ontologically, the following factors are constitutive for it: the previous disclosedness of the for-the-sake-ofwhich in general (being-ahead-of-itself), the disclosedness of what can be taken care of (world as the wherein of already-being), and the understanding self-projection of Da-sein upon a potentiality-for-being toward a possibility of the being 'willed.' The underlying totality of care shows through in the phenomenon of willing." Heidegger, Being and Time, 181.

${ }^{160}$ Other stories in Genesis also record a human response of hinneni. But in the Aqedah, it is in response to God calling him by his covenant name (Abraham!) and the narrator's highlighting of it as critical in structural importance to the narrative. Though Jacob's name was also changed to Israel (Gen 32:28), God never called him by his covenant name Israel, God called him by his birthname Jacob (Gen $32: 11,46: 2)$. 
human agent as the receptive and dynamic agent is exemplified by Abraham's hinneni to God (as the ultimate Other) and to other humans (as true others). Abraham's hinneni of receptivity anticipates learning from the other, which automatically changes the self. We now turn to the cognitive process of growing in knowledge.

\section{Epistemology of the Aqedah}

The discussion on epistemology of the Aqedah will proceed in a different manner from the ontological discussion above. The first verse of the Aqedah will trigger reflections on the epistemology of Abraham's test. This will be followed by a hermeneutically reflexive shift to what the test reveals about God as the tester and Abraham as the testee.

\section{Epistemology of the Beginning Verse}

\section{"After these things"}

From an epistemological viewpoint, "after these things" may appear an unnecessary flourish before the action phrase "God tested Abraham." But time and knowledge are integrally related in Abraham's test. Five points about the relationship between knowledge and time are worthy of consideration at this point on our spiral journey of macro-hermeneutics. First, the truth about Abraham's epiphanies requires temporal distance for ontological clarity. Empirical senses cannot differentiate between a hallucination, a vision, a dream, ${ }^{161}$ or everyday reality from within an event. It requires

\footnotetext{
${ }^{161}$ For instance, two kinds of doubts about dreams vs reality exist. Nagging doubt that questions whether I am awake in the present or now, can be labeled the "Now Dreaming Doubt." Doubt that questions if I have ever been awake can be labeled the "Always Dreaming Doubt." Descartes wrestled with
} 
the distancing effect of time and alternative experiences to make sense of past events and delegate them properly into categories of existence. Second, once historical experiences are understood for what they are in themselves, they form the effective-history ${ }^{162}$ which a person inevitably carries as background patterns for understanding the next event. This is why the more one recalls and employs the biblical history between God and Abraham, the more deeply one will understand the test that follows. Third, if the Covenant Hypothesis is correct that the Aqedah is a test of Abraham's developing covenant character, then time is necessary for allowing the ipse faith decisions of Abraham to sediment into his idem core of integrated character. Temporal distance from the last revelation (banishment of Ishmael in Gen 21) will minimize the possibility of mixed test results from triggered hyper-reactivity to the pending loss of another son. Fourth, since a comprehensive test of covenant character must evaluate love, faith, obedience, hope and morality (all the virtues of traditional interpretive hypotheses), the elicitation of multiple virtues from one test event requires time judiciously inserted into the test design. ${ }^{163}$ Fifth,

both of them in his efforts to ground certainty. "[E]very sensory experience I have ever thought I was having while awake I can also think of myself as sometimes having while asleep; and since I do not believe that what I seem to perceive in sleep comes from things located outside me, I did not see why I should be any more inclined to believe this of what I think I perceive while awake." The Philosophical Writings of Descartes, eds. John Cottingham, Robert Stoothoff, and Dugald Murdoch (Cambridge, UK: Cambridge University Press, 1984), 2:53. Descartes offered no clear answer to these doubts. Temporal distance and other experiences that differ from a dream are necessary to correctly classify past memories as a dream or non-dream.

${ }^{162}$ Gadamer saw temporal distance as an important criterion for genuine understanding. Time is a "filtering process .... It not only lets those prejudices that are of a particular and limited nature die away, but causes those that bring about genuine understanding to emerge as such." History tempered by temporal distance is "effective-history" (Wirkungsgeschichte) - "the actual operation of history on the process of understanding itself." Gadamer wryly noted, "The power of effective-history does not depend upon its being recognized." Thiselton, The Two Horizons, 306-307.

${ }^{163}$ The purpose of a text determines how much time is needed. If short term memory recall is the 
the temporal placement of the test in the Abrahamic cycle of stories, which comes after seven divine revelations and is followed by only one more story, strongly suggests that this is a summative test of what precedes it. A summative test is an assessment "given at the end of units, mid-term and at the end of a course, which are designed to judge the extent of student's learning." 164 However, the Covenant Hypothesis also reveals diagnostic, evaluative and formative functions of the Aqedah as we shall see.

\section{“God tested Abraham"}

The middle phrase, "God tested Abraham," is the epistemological crux of the Aqedah. From the discussion of ontology, God's identity as Creator-Tester means He is the Creator who re-creates Abram as the Divine Promise-Maker and Keeper. The testee's identity is Abram who is willingly becoming Abraham by becoming more open to others,

object of the test - an immediate quiz will accomplish that. If the object is a complex skill done consistently, a series of tests spread out over time is appropriate. If the test goal is to assess maturation of character, a later, unexpected life situation requiring decisive action in a complex situation holds the potential to expose motives, intentions, willingness, resolve, and multiple character traits (Gen 22; 2 Sam 11; 2 Sam 24 vs $1 \mathrm{Chr} 21 ; 2 \mathrm{Chr} 32: 31$ ).

${ }^{164}$ In assessment literature, summative refers to achieving the incorporation of past elements, formative refers to assessing for improvement in the future, diagnostic refers to pinpointing hidden problems or a flaw, and evaluative refers to the level of accountability to a standard. These are not different kinds of assessments but utility goals which affects methods and reflect the values of the participants. See B. S. Bloom, J. T. Hastings, and G. F. Madaus, Handbook on Formative and Summative Evaluation of Student Learning (New York: McGrall-Hill, 1971); Madelina Taras, "Assessment: Summative and Formative: Some Theoretical Reflections," British Journal of Educational Studies 53, issue 4 (Dec 2005): 466-478; Kathleen M. Cauley, James H. McMillan, "Formative Assessment Techniques to Support Student Motivation and Achievement," The Clearing House: A Journal of Educational Strategies, Issues and Ideas 83, no. 1 (July 8, 2010): 1-6. The timing of the test points to the summative aspect. The Covenant Hypothesis also recognizes the evaluative role of the Aqedah by seeing in God's evaluation, the divine norm of past covenant epiphanies (pp. 328-329). The diagnostic function will be addressed in the section of Abraham as the Hermeneutical Testee (pp. 335-341) and the formative function of the Aqedah test will be discussed at the end of the Modified Virtue Ethics subsection of the Axiology of the Aqedah that incorporates Gen 23 as part of the evidence for this (pp. 348-349). 
replying "hinneni." This life-long conversion process will now be tested by the same instructor who brought it into fruition; once again (as in Genesis 1-3) the Creator will assess his creation and on that basis of divine knowledge (Now I know ... because you have done this thing) judge it. But in testing, the Divine Tester is continuing to create, just through another method with duress.

\section{"and [God] said to him, ‘Abraham.' And he said, 'Here I am."”}

The Aqedah does not dwell much on the internal thoughts or feelings of Abraham during the test or on God's internal deliberations, rather, it focuses on external actions and speech. Therefore, our epistemological curiosity must ask the question that appropriates the nature of the revelation provided. The operational mode of the Aqedah suggests "How do we know what we know?" is the right kind of epistemic question. Because the Aqedah is functionally a test, the question hones down to "What about the design and execution of this test reveals what we can know about God and Abraham?"

A well designed test skillfully integrates three kinds of knowledge: "knowing that" (knowing a concept), "knowing how" (understanding an operation), and "acquaintance knowledge" (knowing by relation). ${ }^{165}$ Recognizing these three kinds of

\footnotetext{
165 The first two kinds of knowledge are necessary for any test and the third kind of knowledge controls the aptness of the test. Knowing that (knowing a concept) refers to the purpose or goal of the test: the aspect or standard that the results will be assessed by. Knowing how (understanding an operation) refers to the design of the test, choosing a procedure that will produce results in a form relevant to the norm. But the most critical and sophisticated knowledge is the last of the three kinds of knowledge. Acquaintance knowledge (knowing by relation) refers to the tester's previous knowledge or direct understanding of the test subject. For instance, testing how far a fish can climb a tree is inappropriate for most fish species due to their inability to do so. This is recognized by the quote: "If you judge a fish by its ability to climb a tree, it will live its whole life believing that it is stupid." However, for the mangrove killifish and the climbing fish of India, such a test purpose and design would be appropriate when administered by scientists who are well acquainted with the capability of these species. Acquaintance knowledge should be the basis for the other
} 
knowledge as the ground for good testing, hermeneutical philosophy mines the ore of epistemic reflexivity by asking two questions of the Aqedah test: What does the Aqedah test reveal about the hermeneutics of the Divine Tester and what does the Aqedah test reveal about the human hermeneutics of Abraham as the testee?

\section{God as the Hermeneutical Tester}

God's testing of Abraham reveals reflexively what God already knows about the nature of the testing object (knowing that), how best to bring it out (knowing how), and what is possible through the relation between them (knowing by acquaintance). The Aqedah was a performance test of Abraham, requiring him to respond to a completely new situational threat which was imposed as a divine command, couched in covenant rhetoric and design, with divine guidance and divine assessment at the end. From this, the hermeneutical presuppositions divulged by the design and execution of the test seem to be: God sees Abraham as a historically-conditioned (use of covenantal rhetoric), faithfully contingent (further direction promised), integrative and self-organizing agent (same God that promised a future of descendents through Isaac now requires sacrifice of Isaac) capable of moral phronesis ${ }^{166}$ (the practiced practical wisdom that can apply

two kinds of knowledge.

166 Phronesis was described by Socrates in Meno as moral understanding gained by growing understanding of oneself, a form of virtue. Aristotle distinguished between Sophia (theoretical knowledge), techne (technical knowledge), and phronesis (practical wisdom) in book IV of Nichomachean Ethics. The experienced, deliberative and judgmental aspects of choosing the right action is what Aristotle added to the Socratic mainly knowledge-based definition. W. K. C. Guthrie, A History of Greek Philosophy, Volume 6: Aristotle: An Encounter (Cambridge, UK: Cambridge University Press, 1981), 348. 
previous knowledge to a completely unexpected situation). This is what the Aqedah test design reveals about divine anthropology — that is, God's understanding of humanity. ${ }^{167}$

Phronesis appears to be what is being evaluated, for God's list of commendations evokes past revelations, and rewards covenant blessings tied to Abraham's test response (because you have done this thing). But since we have already established that the Aqedah test is on Abraham's covenant identity, his character and being, how does phronesis relate to his being? Heidegger believed phronesis was the disposition or habit that reveals the being of action. ${ }^{168}$ The covenant journey changed an obedient Abram to Abraham, a new covenant identity, by faithfully learning and practicing the covenant lessons. The Aqedah tested the integration of those lessons into Abraham's character and

\footnotetext{
${ }^{167}$ God's hermeneutic of what a human is, exceeds Descartes's ahistorical, reductionistic, solipsistic cogito. It eclipses Hume's unmixed aggregate bundle of physical sensations without a center and Nietzsche's illusory perspectivist with abstract or non-existent truth. The test command reveals that the addressed human being is a temporal-historical, self-aware and self-organizing, dynamic agent with responsible phronesis that remains open (hinneni) to the other. Jane L. MacIntyre, "Personal Identity and the Passions," Journal of the History of Philosophy 27, no. 4 (Oct. 1989): 545-557; Paul Ricoeur, Oneself as Another, 4-16; Kierkegaard After MacIntyre, eds. John J. Davenport and Anthony Rudd (Chicago: Open Court, 2001), xxv.

${ }^{168}$ Heidegger appropriates Aristotle's phronesis as a praxis "movement of questioning which is concerned with the meaning of human existence in a way that is not wholly dependent on a cognitive comportment towards others, the world and ourselves but which is, rather, played out as a concern for the essence of the human in and as concrete and complex (situational) engagements." McGuirk has concerns that Heidegger's appropriation of phronesis as a way to understand the ontology of authentic being with its ownmost possibilities could misplace Aristotle's concept of good (agathon) as the goal of phronesis with Heidegger's authentic being as the goal. James McGuirk, "Heidegger's reading of Aristotle's Ethics: reappropriations, transformations and the spectre of Kierkegaard" p. 2, accessed 3 March 2019, https://www.academia.edu/36233148/Heideggers_reading_of Aristotles_Ethics_reappropriations transformations and the spectre of Kierkegaard; Walter A. Brogan, Heidegger and Aristotle: The Twofoldness of Being (Albany, NY: State University of New York Press, 2005), 147; Leena Kakkori and Rauno Huttunen, "Aristotle and Pedagogical Ethics," Paideusis 16, no. 1 (2007): 17-28. I understand McGuirk's concern about authentic being as a worthy goal for phronesis, for what if one's authentic being is sociopathic or evil? Is authenticity to be pursued then, regardless? Heidegger's political leanings may serve as a warning here.
} 
habits by challenging him with a completely new threatening situation which assessed his capacity for deliberation, experience and moral judgment at this stage of his life.

What was God's original goal or telos for Abraham's phronesis? Kierkegaard posited God as the ultimate and final telos. ${ }^{169}$ Although I agree with Kierkegaard that God is the ultimate eternal telos for all believers, God Himself had clarified three aspects of an explicit telos for Abraham's covenant journey in his initial call. It was for God to bless Abraham, to make him into a blessing, in order to bless the world through him (Gen 12:13). All three aims dovetail into the telos of embodying divine blessing in interactions with others.

Therefore, the Covenant Hypothesis understands God's final list of covenant blessings as both reiteration and current recognition of how far Abraham has become a divine blessing by evaluating his test actions (the four verb clusters and speeches in the Aqedah). It is his integration of the covenant lessons and continuing responsiveness to divine correction by the angel of Yahweh ("you obeyed my voice") that passed the test.

From the Aqedah divine interpretation, the covenant identities of God and Abraham are seen to be grounded in function, in use: (1) God's own being is the self-

${ }^{169}$ Kierkegaard did locate human telos in human authenticity but went beyond Heidegger's authentic being which was defined by Heidegger as the opposite of being self-consciously determined by others' expectations or "theyness." Kierkegaard agreed that human authenticity, especially of a Christian, outpaced societal norms (the ethical or universal) but Kierkegaard then anchored it in "absolute relation" to the Absolute. John J. Davenport, "Towards an Existential Virtue Ethics: Kierkegaard and MacIntyre," Kierkegaard After MacIntyre: Essays on Freedom, Narrative, and Virtue, eds. John J. Davenport, Anthony Rudd (Chicago, IL: Open Court, 2001), xxvi, 274. The Covenant Hypothesis agrees with Kierkegaard that the telos of human authenticity is found in an absolute relation to God, while insisting that, unlike Kierkegaard, God must not be reduced to merely His most recent utterance, a divine verbal locution in isolation. All of God's interactions over time must be embraced as revelatory of His being in order to authentically hear or understand the meaning of what God is saying now. 
referential dynamic foundation (By Myself) and telos for certainty and truth in language (I have sworn, declares the Lord), (2) Abraham's being (God-fearing and continuously obedient) has been uncovered by his test actions (because you have done this thing) as evaluated against his past covenant experience. To summarize, the divine hermeneutic is based on God's own being as the source for truth and certainty and sees humans as integrative, active agents who reveal the state of their moral being by phronesis. This is what the Aqedah reveals about divine language, testing and anthropology.

From hermeneutical assumptions undergirding the divine command and divine interpretation, we now turn to the issue of divine omniscience. In the Aqedah, God praised Abraham with the self-referential words "Now I know that you fear God" (Gen 22:12). If this is means God did not know a propositional fact, but that now He knows it—-this threatens the classic theistic concept of divine omniscience which asserts God knows every true proposition from eternity. ${ }^{170}$ Therefore, Augustine ${ }^{171}$ and Aquinas ${ }^{172}$

\footnotetext{
${ }^{170}$ Classical Theism characterizes God as the metaphysical absolute being using scriptural proofs and the Anselmian conception of perfect being theology. In regard to divine knowledge, God is omniscient which means he has perfect actual knowledge of everything in the past, present and future. J. P. Moreland and William Lane Craig, Philosophical Foundations for a Christian Worldview (Downers Grove, IL: InterVarsity Press, 2003), 501. Biblical verses used to support this include: God knows the secrets of the heart (Ps 44:21), his understanding is infinite (Ps 147:5), his eyes are in every place (Prov 15:3); God knows all things (1 John 3:20); God knows the past, present and future (John 13:19; Acts 15:18; Isa 42:8-9; 45:21; 46:10). See also Ps 139:1-8.
}

${ }^{171}$ Augustine explained that divine testing was to make Abraham more self-aware for this test "is not aimed at his [God] getting to know something he was ignorant of before but at bringing to light what was hidden in a person. . . . People are not as well known to themselves as they are to their creator." Augustine, "Sermon 2: Abraham tested by God" in Sermons (1-19) on the Old Testament, trans. Edmund Hill, The Works of Saint Augustine, vol 3/1 (Hyde Park, NY: New City Press, 1990), 177

${ }^{172}$ Aquinas believed it was for others, "The meaning is not that He who knows all things from eternity began to know at that moment, but that He made known Abraham's devotedness by that declaration." Aquinas cited in Beach and Powell, Interpreting Abraham, 52. 
interpreted the self-revelatory locutionary content of this Aqedah announcement as a perlocutionary utterance directed at Abraham and others.

But canonical context must be consulted to understand this self-revelatory divine pronouncement as intended to be heard by Abraham. Three events in their shared history provide relevant background for correct understanding. They are (1) Abraham's own analogous phrase "now I know" in Genesis 12, (2) God's reference to contingent divine knowledge in Genesis 18, and (3) God's preventive interventions based on divine knowledge of inner motives in Genesis 20.

(1) When Abraham used a similar phrase about his knowledge in Gen 12:11, literally, "Behold, now ${ }^{173}$ I know that you are a beautiful woman," it did not indicate he was ignorant of Sarah's beauty before the present moment. It indicated a new state of emotional concern arising from one aspect of his previous propositional knowledge in response to a new situation: "When he was about to enter Egypt, he said to Sarai his wife" (Gen 12:11). Abraham's phrase indicated a change in his emotive and imaginative consciousness based on pre-existing propositional knowledge.

(2) In Gen 18:21 God seemed to express a contingent state of divine knowledge when he told Abraham his mission was to "see whether they have done altogether according to the outcry that has come to me. And if not, I will know." However, Abraham clearly assumed God already knew the moral

173 The Hebrew term na can be translated as now or please. BDB, s.v. "נא." 
situation for Abraham interceded earnestly as if God was going to destroy

Sodom and Gomorrah. Abraham's assumption of God's comprehensive

propositional knowledge of the cities was not rebuked by God as presumption

even though it contradicted God's locutionary content about a yet undecided

investigation. If this reading of God and Abraham's interactions on the

completeness of God's propositional knowledge is correct, why would God

speak in a contingent manner? One perlocutionary possibility is that God

desired Abraham's prophetic engagement by describing divine knowledge as

unresolved. But a locutionary possibility also exists.

Perhaps God was truthfully exposing a deliberate divine process in suspending one form of divine temporal knowledge, that of divine judgment, until after a final face to face engagement with the sinful inhabitants of the cities. After Sodom's mob attempted to abuse the angelic messengers and revealed their recalcitrant mindset against reason and Lot's pleas, divine emotive-relational and factual propositional knowledge coalesced ${ }^{174}$ into a final comprehensive assessment, and the knowledge-event of divine judgment ensued with catastrophic consequences. God's exhaustive propositional

\footnotetext{
${ }^{174}$ The idea that God's relational-emotive condition is not necessarily synonymous with his propositional knowledge is suggested by the prophet's description of divine emotions in relation to divine propositional knowledge that modifies and results in final divine judgment. Hosea 11:7-9, "My people are bent on turning away from me; so they are appointed to the yoke, and none shall remove it. How can I give you up, O Ephraim! How can I hand you over, O Israel! How can I make you like Admah! How can I treat you like Zeboiim! My heart recoils within me, my compassion grows warm and tender. I will not execute my fierce anger, I will not again destroy Ephraim; for I am God and not man, the Holy One in your midst, and I will not come to destroy."
} 
foreknowledge of all the options possible is focused through God's dynamic creation of opportunities for free human and divine interactive choices (a visit to Abraham and a final visitation to Sodom) which then fused into a historical actuality with real consequences. ${ }^{175}$

(3) One last insight for the Aqedah issue of divine knowledge is provided by Genesis 20 where God's awareness of Abimelech's integrity was complete even as He threatened Abimelech's life for his naïve procurement of Sarah as his wife. God's perfect knowledge of Abimelech's pure motives and incomplete comprehension was what spurred His divine intervention to prevent Abimelech from sinning unknowingly against God.

Keeping in mind these events as provided literary context, God's words, "Now I know that you fear God" did not necessarily communicate to Abraham that God didn't know a certain proposition. Each of the three previous events presupposed full propositional knowledge of the matter by the speaker even as they spoke in a contingent manner. Instead, careful analysis of previous events offer more subtle and supple ways to understand God's omniscience. The three events reveal (1) the phrase "now I know" may mean that a latent aspect of a known propositional fact has now become predominant due

\footnotetext{
${ }^{175}$ Martin Hanna asserts, "God's foreknowledge is exhaustive, definite, and dynamic." As I understand his article, Hanna describes God's propositional foreknowledge to be exhaustive of all existing, past and possible future options. God then chooses to create opportunities to facilitate free will choices which naturally delimits the range of exhaustive possible propositional options to those available to the participants within and from the event. Contingent on what humans and God interactively and freely choose to do within that event, God and human beings "co-create" the actual future (without adding any new propositions to the pre-existing propositional foreknowledge of God). Martin Hanna, "Foreknowledge and the Freedom of Salvation" in Salvation: Contours of Adventist Soteriology (Berrien Springs, MI: Andrews University Press, 2018), 58.
} 
to a new event or context (Gen 12), (2) before divine judgment is settled and enacted, God allows the judged to publicly exhibit their true moral condition through direct free interactions so His final integrated judgment can be seen as righteously accurate (Gen 18), and (3) when a God-fearing servant with moral integrity is about to commit a grave mistake unknowingly, sometimes God intervenes to clarify confusion by thwarting their sinful intent while affirming their sinless motives (Gen 20). All three facets correspond to the Covenant Hypothesis explication of the angel of YHWH thwarting Abraham's intent to sacrifice Isaac. When all three previous events are kept in mind, a plausible paradigm for a richer understanding of God's reference to His dynamic divine knowledge in the Aqedah event begins to emerge.

These findings suggest God's omniscience may be multifaceted, confirmatory, relational and discretionary, including a "present omniscience" of human reality which correlates experientially with human changes through time. ${ }^{176}$ The topic of divine omniscience certainly requires its own dissertation, or multiple dissertations, but all I am

${ }^{176}$ While in open theism, future libertarian free choices are not proper objects of knowledge for anyone including God (the future is open) and in Arminianism they are proper objects of knowledge, both groups agree that God's knowledge is consequent to historical events and not on God's pre-determining will (God foreordains all events) as Calvinism asserts. Some kinds of knowledge are inherently dynamic. Contextualized present knowledge such as "it is 1:23 pm on March 4, 2019 in Berrien Springs, Michigan" changes with every minute that passes. See Steven M. Studebaker, "The Mode of Divine Knowledge in Reformation Arminianism and Open Theism," JETS 47, no. 3 (September 2004): 469-480; Michael Carasik, "The Limits of Omniscience," JBL 119, no. 2 (2000): 221-232; Amos Yong, "Divine Omniscience and Future Contingents: Weighing the Presuppositional Issues in the Contemporary Debate," ERT 26, no. 3 (2002):240-264; and Martin Hanna, "Foreknowledge and the Salvation of Freedom," 33-59. 
suggesting at this point is that God's Aqedah phrase "Now I know" must be understood and heard as Abraham might have heard it, heard through the filter of Abraham's history.

In summary, the hermeneutical insights from the epistemology of the Aqedah are: (1) divine anthropology sees the human being as a historical self-aware, self-integrating moral agent that can choose to be open to the other, (2) the meaning of God and Abraham's covenant identity is functional, not material or substance-based, (3) the truth of the test assessment is grounded in God's attestation of certainty based on His own Being (as the Divine Tester of the Aqedah), (4) God's reference to His own present omniscience must be interpreted by the relevant context as Abraham might have understood it, in order to be unpacked correctly.

\section{Abraham as the Hermeneutical Testee}

From the subjective point of view, Abraham was faced with a cataclysmic covenant crisis. Existential philosophy emphasizes that crisis is inherent to life itself; "human life according to its essential nature and in every moment lies in crisis and can only be conceived through crisis." 177 But since the Aqedah was a divinely imposed test, this implies some learning was taking place. Otto Bollnow coined the term encounter to describe crisis-like situations that carry pedagogical implications. Jani Koskela explained encounter as "a fundamental experience in which the subject meets something new, strange, uncontrollable, and (to the subject) incomprehensible. It is a meeting with the

\footnotetext{
177 Otto Bollnow, Crisis and New Beginning: Contributions to a Pedagogical Anthropology, trans. Donald Moss and Nancy Moss (Pittsburgh, PA: Duquesne University Press, 1987), 4-5.
} 
irrational. ... By no means is encounter necessarily a pleasant experience; it affects the subject profoundly, leading to self-examination or reflection and a change in one's way of living or being." ${ }^{\prime 178}$ The Aqedah test appears to be a classic encounter.

But what would be the benefit of an encounter like the Aqedah? Koskela suggests that discontinuous education through an encounter may (or may not) lead to what Bollnow called an awakening of the self by peeling off "irrelevances to this existential level of description, [peeling them] out of the way of awakening to conscience and true self." ${ }^{\prime 17}$ This means awakening to the true self can be a painful. Heidegger described the process of personal unconcealment as occasionally brutal: "This selftransparency is no self-evident starting point, but has to be wrested in explicit exertion from ambiguity, unclarity and vagueness." ${ }^{180}$ Bollnow's concept of awakening and Heidegger's unconcealment complement each other.

If the Aqedah was an existential encounter designed to awaken and unconceal the authentic core of Abraham by peeling off superficial layers, why was Isaac's sacrifice chosen as the design of the test? It is because the true self is sometimes disguised under a layer of incapacitating fear. "Fear, thus as a mode in Dasein's being, seems to remind or reveal this inherent 'error' or incapability in Dasein." ${ }^{181}$ Hence, Koskela suggests an

\footnotetext{
${ }^{178}$ Koskela, "Discontinuity," 50-51.

179 Jani Koskela, "Discontinuity," 49. Of course, an encounter may also end in disintegration and despair. It is a risk-laden event.

${ }^{180}$ Jani Koskela, “Discontinuity,” 79.

181 Jani Koskela, "Discontinuity,” 137.
} 
effective encounter may choose to target the locus of a deep seated phobia, "one should not therefore overlook the epistemic possibilities of fear as unconcealment either in educational processes, as those processes are first and foremost processes of understanding" for "when one is in fear, one is considered to remain in a lie about oneself ....when one is fearful, he or she is not being true to all the capacities a person has, therefore is not being true to oneself. But when one is not fearful, one is able to live to the fullest of one's capabilities." ${ }^{182}$ From the events preceding the Aqedah it is clear that Abraham has one deep fear that drives him to relinquish family members without resistance to authority figures repeatedly. It is his fear of death.

Abraham's fear of death stems from a deeper innate sense of mortal finitude ${ }^{183}$ which the long history of his wife's barreness may have compounded. The sense of finiteness, commonly expressed as the fear of death, is the most basic universal and pervasive fear of humankind. Even after Abraham's fear was mitigated by the birth of Isaac, as a life-long phobia, it may have affected Abraham's hermeneutics in interpreting the test command. All physicians understand that the first time a patient is told they have cancer, the overwhelming fear of death often blocks their ability to hear the rest of the details and instructions must be repeated later or multiple times. This may explain why

182 Jani Koskela, “Discontinuity,” 137-139.

183 "There is a ground of sadness that may be called the sadness of the finite. This sadness is nourished by all the primitive experiences which, to express themselves, have recourse to negation: lack, loss, dread, regret, deception, dispersion and irrevocability of duration. Negation is so obviously mixed in them that we can indeed hold this experience of finitude for one of the roots of negation." Paul Ricoeur, "The Concept of Fallibility" in Contemporary European Ethics: Selected Readings, ed. Joseph J. Kockelmans (New York: Doubleday \& Company, 1972), 117. 
the enlightening rhetorical nuances in the divine test command were missed by Abraham. ${ }^{184}$ His mixture of crippling fear and growing faith ${ }^{185}$ was being tested so Abraham could realize the sober truth about himself.

Two core concerns underlying the fear of death are the fear of powerlessness and the fear of meaninglessness. ${ }^{186}$ Those primarily afraid of the meaninglessness of life can face death and become willing martyrs if they discover a meaning more valuable than their individual lives. Those primarily afraid of powerlessness can also face death with courage if they find access to a power greater than death, either directly or through an allpowerful being. Which is Abraham's core concern? Abraham's fear of death is specifically a fear of being violently killed (Gen 12:12; 20:11), not of dying from old age. This is why God tries to cure his fear with a prophecy of a peaceful death in Gen 15:15 "As for you, you shall go to your fathers in peace; you shall be buried in a good old age." But even God's personalized prophecy did not dislodge Abraham's phobia of a violent death, for it was after God's assurance, during Sarah's gestational year with Isaac, that this fear of being killed motivated Abraham to relinquish Sarah to Abimelech (Gen 20), command.

${ }^{184}$ Similar fears may cause readers to miss or dismiss the nuances when they read the Aqedah test

185 Ricoeur sees man as a mixture of "originating affirmation," affirmation of goodness given at creation, and "existential difference," the finiteness and fallibility of human existence. "This 'mixture' has appeared to us as the progressive manifestation of the fault which makes of man, mediator of the reality outside himself, a fragile mediation for himself." Paul Ricoeur, "The Concept of Fallibility," 118.

${ }^{186}$ Lisa Iverach, Ross G. Menzies, and Rachel E. Menzies, "Death Anxiety and its Role in Psychopathology: Reviewing the Status of a Transdiagnostic Construct," Clinical Psychology Review 34, no. 7 (November 2014): 580-593. 
giving away his chance to be Isaac's father. Once again, God had to rescue his covenant seed.

Clearly then, this unresolved issue is the lifelong hermeneutical mood ${ }^{187}$ that Abraham brings into the fearsome Aqedah event. Through God's test command, Abraham is brought face to face with what he has been assiduously avoiding all his life, and is completely flooded by it. The violent test command makes explicit the exact nature of Abraham's fear of a violent imposed death but it goes further, it infinitely expands it by requiring him to sacrifice Isaac. Abraham faces a possible future of absolute nothingness except boundless remorse. God's required journey plunges him into a state of continual fearing for three days. Stripped of all the accumulated accoutrements of a powerful tribal prince down to a donkey and three oblivious adolescent boys, Abraham has only his own memories and godly faith to deal with his hidden fear, exposed raw by the test command.

By the time he orders his servants to remain, Abraham's words reveal his growing faith conviction that somehow, both he and Isaac will return. By the time Abraham answers Isaac's question, perhaps Abraham hopes to find divinely provided animal at the altar site. But, according to the writer of Hebrews in the New Testament, by the time

\footnotetext{
${ }^{187}$ Mood here does not refer to a passing feeling but to Heidegger's usage of the term referring to the state of emotive attunement that an embodied human being has toward reality. It is the affective environment of our thinking, deliberating and choosing. Heidegger even puts the most rational endeavor, philosophy, within it: "Philosophy in each case happens in a fundamental attunement [ground mood]. Conceptual philosophical comprehension is grounded in our being gripped, and this is grounded in a fundamental attunement." Martin Heidegger cited by Robert D. Stolorow, "Heidegger, Mood and the Lived Body: The Ontical and the Ontological," Janus Head: Journal of Interdisciplinary Studies in Literature, Continental Philosophy, Phenomenological Psychology, and the Arts 13, no. 2 (2014): 5-11.
} 
Abraham grasps the knife to slay his son, Abraham has given up looking for the animal (which is behind him in a bush) because he has placed his faith in God's absolute power to resurrect Isaac, since "from one man, and him as good as dead, were born descendants," Abraham "considered that God was able even to raise him [Isaac] from the dead" (Heb 11:12, 19). Yet, when the angel of YHWH prohibits Abraham's literal obedience, he instantly obeys, finds the waiting ram and exults in divine provision as the pre-ordained test solution.

Abraham's sense of powerlessness as expressed in his life-long phobia of being killed had found refuge in the resurrection power of the Almighty over death. This understandable move, extrapolated from his faith experience requires no divine chiding because it remained faithfully God-oriented (Now I know you fear God) but his grasping of the knife also revealed to himself who he was at the core, a violent paradox. Abraham was a God-fearing mortal gripped with an unresolved fear of being killed, this made him one that was willing to kill someone else in a religiously cultic setting. Though the theocentric trajectory of the Covenant Hypothesis points to the missed option of mediatory intercession for Isaac (which appeals to God's character) over Abraham's resurrection hope (which appeals to God's power) what finally counts in the end is Abraham's openness to divine prohibition and redirection as captured in the final judgment of Abraham—-"you obeyed My voice."

Thus, epistemologically, the Aqedah test is now seen as a diagnostic test that reveals the hidden underlying condition of Abraham and generally of humankind. Abraham as the religious human archetype reveals the universal human condition of 
being haunted by the fear of death. His phobia of being killed disclosed a core fear of powerlessness that drove him to grasp God's absolute power over death. Unfortunately and ironically, it is precisely Abraham's hope in the power of resurrection that caused him to take up the knife to kill his son. Resurrection requires prior death. Is faith in absolute power the moral lesson of the Aqedah? Thus, we cannot escape the ethical predicament in praising Abraham's hope of resurrection as faith-filled moral justification for being willing to kill Isaac in the Aqedah. Clearly, the axiology of the Aqedah begs for our attention and we will do that next.

\section{Axiology of the Aqedah}

The discussion of axiology in the Aqedah will follow the pattern of the previous section on epistemology. This means a brief reflection on the axiology of the first verse of the Aqedah will be followed by two discourses. The first will be on the ethics of the Aqedah and the second will be on aesthetics. A brief summary will then conclude this section.

\section{Axiology of the Beginning Verse}

\section{"After these things"}

The axiology of the first phrase of the Aqedah, "after these things," may reach all the way back to the point where God separated Abraham from Haran, his birth culture, and clan. If this separation was intended to instill a new set of religious and moral values $^{188}$ one would expect the ensuing divine revelations to be theological or moral

\footnotetext{
${ }^{188}$ The covenant lessons can be seen as teaching Abraham parental virtues: (1) Envisioning—Gen
} 
instruction. Instead, almost all of their encounters start with imperatives requiring action: leave your past, believe this land is yours, wander about, look around, look up at the stars and believe, prepare a covenant ritual, walk before me perfectly, believe you will get a son named Isaac, circumcise all men, expect a son, entrust Ishmael to me, go, walk, offer up Isaac as a sacrifice. This suggests that through continual practice, Abraham's faith in God was not limited to knowing propositional tenets but was concretized into lifelong habits of practicing his faith, growing in covenant phronesis.

\section{"God tested Abraham"}

Near the end of this covenant journey "God tested Abraham." From the perspective of various ethical theories, the ethical issue is that God demanded Isaac as a burnt sacrifice without providing moral justification. Divine Command Theory (DCT) defines the moral status of an act as good if it is in compliance with an explicit divine command; according to DCT, sacrificing Isaac in compliance to the divine command is not to be classed with murder but is by definition a righteous act. ${ }^{189}$ Deontological Kantianism would reason that sacrificing another cannot be universally realized as a rational rule for it doesn't treat a person as an end and it is amendable to self-love because it appeases a deity for possible personal benefits; so sacrificing Isaac, even in

12:1-3, (2) Revealing—Gen 12:7, (3) Grounding—Gen 13:14-17, (4) Covenanting—Gen 15, (5) Branding - Gen 17, (6) Negotiating-Gen 18, (7) Releasing-Gen 21:12-13.

${ }^{189}$ Wyndy Corbin Reuschling, "Divine Command Theories and Ethics," in Dictionary of Scripture and Ethics, ed. Joel B. Green (Grand Rapids, MI: Baker Academic, 2011), 242-246. 
compliance to a divine command would be wrong. ${ }^{190}$ Consequentialism holds the results of an action as the basis for deciding whether it is right or wrong; since the death of Isaac would result from the order, obedience to it would be wrong. ${ }^{191}$ Pragmatic ethics focuses on experiment and deliberation to discover which actions are beneficial and which are not; but for this individual situation, hope-filled experimentation could turn tragically irreversible, thus obedience is wrong. ${ }^{192}$ Finally, the focus of Virtue Ethics moves from external evaluation for the morality of an action, to the agent's internal character as the basis for morality. A Virtue ethicist avoids prescribing any particular action but may offer the advice, "Act as a virtuous agent would act in this situation." 193 This only begs the question because what counts for virtue or which character is to be modeled in this

${ }^{190}$ Joseph B. Onyango Okello, "Deontological Ethics," in Dictionary of Scripture and Ethics, ed. Joel B. Green (Grand Rapids, MI: Baker Academic, 2011), 214-216; Immanuel Kant, Groundwork of the Metaphysics of Morals, trans. and ed. Mary Gregor, Cambridge Texts in the History of Philosophy (Cambridge, UK: Cambridge University Press, 1998), 44; Craig G. Bartholomew and Michael W. Goheen, Christian Philosophy: A Systematic and Narrative Introduction (Grand Rapids, MI: Baker Academic, 2013), 145.

${ }^{191}$ Vladimir Ignatkov, “Consequentialism," in Dictionary of Scripture and Ethics, ed. Joel B. Green (Grand Rapids, MI: Baker Academic, 2011), 171-172.

192 John Dewey, Human Nature and Conduct (New York: Henry Holt and Company, 1922); Hugh LaFollete, "Pragmatic Ethics" in The Blackwell Guide to Ethical Theory, eds. Hugh LaFollette and Ingmar Persson (Malden, MA: Wiley-Blackwell, 2013), 400-419.

${ }^{193}$ Nafsika Athanassoulis, "Virtue Ethics," The Internet Encyclopedia of Philosophy, accessed 2 Aprili 2019, https://www.iep.utm.edu/home/about/; Nikki Coffey Tousley and Brad J. Kallenberg, "Virtue Ethics," Dictionary of Scripture and Ethics, ed. Joel B. Green (Grand Rapids, MI: Baker Academic, 2011), 814-819. 
situation is unclear. No current ethical model appears adequate to the ethical challenge of the Aqedah.

\section{"and [God] said to him, 'Abraham.' And he said, 'Here I am."”}

This last phrase of verse one suggests one direction for a trans-ethical norm or telos: "He [God] said to him, 'Abraham!'” God's words bookend the covenant journey of Abraham with the divine call and the divine test which remain consistent on the divine telos. The divine telos of the covenant journey was explicit in the initial call to Abraham - "And I will bless you and make your name great and you will be a blessing . . .. and in you all the families of the earth will be blessed." The Aqedah echoes it; "And in your offspring shall all the nations of the earth be blessed." God's covenant telos was that everyone on earth would become blessed ${ }^{194}$ through Abraham and his seed. Divine blessing offers a trans-ethical norm and telos for assessing value in the Aqedah.

\section{Modified Virtue Ethics}

With the telos of blessing in mind, the arc of the Abrahamic narratives reveals the Creator-Promise-Keeper was molding the faithful and willing Abram into the covenant Abraham, the embodiment of God's blessing (you will be a blessing, Gen 12:2). This

\footnotetext{
${ }^{194}$ Blessedness is the final telos. This moves from the deontologist framing of blessing as the moral duty (as commanded by God) to bless others, to a consequentialist framing of results - that others will end up blessed. But God's call also includes virtue theory for Abraham is to become a blessing himself, a covenant identity, from God working on Abraham via blessings. The final condition of passive blessedness parallels the pattern of creation days that end on the Sabbath. "Both accounts conclude with the seventh step describing a state of being resulting from the divine action: 'all the families of the earth shall be blessed" (12:3) // "the heavens and the earth, and all the host of them were finished" (2:1). Doukhan, Genesis, 198.
} 
covenant journey aligns with the developmental process of internalized morality assumed in Virtue Ethics, where an agent must accumulate experience and integrate virtues into a complex yet stable character that consistently demonstrates prudence and practical wisdom in ethically challenging situations. However, the Aqedah test seems to be a test of Divine Command Theory where divine commands define morality and Abraham's exacting compliance is praised. If these two ethical paradigms are combined, the Aqedah appears to be a Divine Command Theory challenge within the narrative framework of a Virtue Ethics journey. This juxtaposition of two ethical models more fully captures the historical dynamics and unsettling legacy of Abraham's journey and test choices better than either model does alone.

From a Divine Command Theory point of view, Abraham's compliance would be considered moral. ${ }^{195}$ However, even Virtue Ethics can be used to justify Abraham's

195 Though I will not take the time to develop this fully, a modified Divine Command Theory could come closer to alignment with the Covenant Hypothesis. As it currently stands, Divine Command Theory (DCT) is a meta-ethical theory that claims the status of a human action as morally good is dependent on whether God clearly commands it. It is implicitly assumed that the most recent utterance of a divine command defines morality a-historically, i.e. previous divine commands are to be considered nullified if a later divine command clearly contradicts it. Now, if the norm for defining good actions included God's past exemplary actions, divine affirmation of human behavior (even if the human act was not specifically commanded by God- such as Abraham's sacrificing of the ram) and all of God's previous commands, this broader base for morality would allow extrapolation from biblical paradigms to extrabiblical situations. This wider base would include all their prior interactions including Abraham's intercessions (Gen 18) to which God acceded. This expansion of the DCT approximates the contextually faithful Covenant Hypothesis base for morality. See also Ze'ev Levy, "On the Aqedah in Modern Philosophy" in Journal of Jewish Thought and Philosophy (2007), 85-105; Ansgar Santogrossi, "Scotus' Method in Ethics: Not to play God-A Reply to Thomas Shannon" in Theological Studies 55 (1994), 314329; David Efird, "Divine Command Theory and the Semantics of Quantified Modal Logic" in New Waves in Philosophy and Religion, eds. Yujin Nagasawa and Erik J. Wielenberg (Basingstoke, UK: Palgrave Macmillan, 2009), 102.

Other modifications of Divine Command Theory have been proposed. Robert Adams modified divine command theory posits an act is wrong only if it defies the commands of a loving God, thereby appealing to divine omnibenevolence (as understood by humans) as the standard. Thus, he rejects the Aqedah. Robert Merrihew Adams, Finite and Infinite Goods: A Framework for Ethics (New York, NY: Oxford University Press, 1999), 290; Phillip Quinn moved the norm of good from God's command to 
choice to "kill his son" using historical context. Abraham's test response could be justified as emulating the best contextual practices of religious cultures around him, exemplifying ideal religious servant characteristics by executing all religious orders with exemplary fidelity, loyalty, devotion and unmitigated love. The religious servant mode does not question or doubt, does not reason or challenge the master, does not integrate or petition, the perfect servant obeys literalistically with a positive attitude out of love (or fear, it doesn't really matter which) for the master. This servant mode persists as a virtuous model in religious imagination to this day as an aspect of fideistic fundamentalism.

However, Virtue Ethic justification for Abraham has three major inherent weakness. They are (1) because it is character-based, Virtue Ethics doesn't offer direct guidance for action in a challenging or ambiguous situation, (2) because it is agentfocused, the focus of action is not toward the other but toward the virtues of the self, and (3) because it is developmentally-oriented, it remains highly context-dependent on surrounding culture for defining what a virtue is, which virtues ought to be incorporated, and how to apply them. Thus, Abraham's act of willingness to kill Isaac could be lauded

God's will. He also rejects the Aqedah. Phillip L. Quinn, “Agamemnon and Abraham: The Tragic Dilemma of Kierkegaard's Knight of Faith," Journal of Literature and Theology 4, no. 2 (1990): 181-193; Linda Zagzebski moved the norm of good to God's motive. Linda Zagzebski, Divine Motivational Theory (New York, NY: Cambridge University Press, 2004), 261; Christian Miller moved the norm of good to God's desire. Christian Miller, "Divine Desire Theory and Obligation" in New Waves in Philosophy and Religion, eds. Yujin Nagasawa and Erik J. Wielenberg (Basingstoke, UK: Palgrave Macmillan, 2009), 105-124. The Covenant Hypothesis points out that humans can only surmise God's desire, motive, will, and love from His historical actions, thus what defines actions as morally good depends on their alignment with the moral scope of God's self-revelations. 
as exemplary of a virtuous perfectly subservient servant but it clearly fails the explicit covenant telos of Abraham becoming a divine blessing to Isaac.

God's telos of making Abraham a divine blessing offers a biblical corrective to the three weaknesses of Virtue Ethics. The notion of divine blessing carries three connotations: a normative source in God's revealed character, transcultural values extracted from participatory revelations both holy ${ }^{196}$ and good, and a bestowal of positive consequences for the recipients who are to be blessed as God's equally beloved creatures. God's promises to Abraham were to transform him through blessings into a physical agent embodying divine favor — a living, breathing divine blessing ${ }^{197}$ so that other families would end up blessed. Since God is the exemplar, Abraham must reflect God's revealed covenant character.

What becoming a blessing shares in common with Virtue Ethics is the developmental process of admiring, learning, integrating, and socially practicing virtues and practical wisdom. But becoming a blessing requires more than appropriation of observed or deliberated virtues. It requires God's word and divine transformative power to infuse the believer's perspectives, motives, and even subconscious drives as they willingly lek-lekha (walk-for/to/with-yourself) with God through life. The divine

${ }^{196}$ Holy is used here in the attributive sense, recognized as belonging to God. Full holiness is exclusive to God, but God can separate something from the common, sanctify it and make it holy or religiously belonging to Himself. The Sabbath is an example (Gen 2:3). Abraham is another (Gen 12:1-3). Zondervan Illustrated Bible Dictionary, s.v., holiness.

197 "Abraham is not just the passive object of God's blessing, Abraham (and his spiritual children) should infer the duty to be a blessing to the nations. The result of being blessed is a missionary lesson: 'bringing salvation to all planet earth."” Doukhan, Genesis, 200. 
interpretation at the end of the Aqedah indicated that all but one covenant revelation was actualized by Abraham in the test. Only the covenant lesson of prophetic intercession was missing. Thus, Abraham fell short of being a divine blessing to Isaac when he picked up the knife in the Aqedah. Clearly, the Aqedah was a covenant evaluative test.

It would be natural to wonder at this point if Abraham learned from his test and incorporated the missing lesson of covenant intercession after the Aqedah. In other words, was the Aqedah test a formative test as well? I believe the Bible offers indirect evidence for that possibility. In the following and final narrative that properly belongs to the Abrahamic cycle, that of Abraham's purchase of the Cave of Macpelah, we see a very different Abraham facing the Hittite council (Gen 23) than the Abraham that cowered behind defensive excuses in the Philistines court (Gen 20). This post-Aqedah Abraham is amazingly not afraid to publicly expose his political, social, emotional powerlessness before the natives of the land: "I am a sojourner and foreigner among you; give me property among you for a burying place, that I may bury my dead out of my sight" (Gen 22:4). From this position of socio-politico-emotional weakness, in parallel manner to his previous intercession with God over Sodom and Gomorrah ("I, who am but dust and ashes" Gen 18:27), Abraham negotiates respectfully but persistently with the Hittites until he obtains a costly but legitimate legal foothold in God's promised land. ${ }^{198}$

The patriarch who previously gave away his living wife and with her-the covenantal promise of her son, to Abimelech to save his own skin—now exposes his

\footnotetext{
${ }^{198}$ Meir Sternberg, "Double Cave, Double Talk: The Indirections of Biblical Dialogue," in Not in Heaven, eds. Jason P. Rosenblatt, Joseph C. Sitterson, Jr. (Indianapolis, IN: Indiana University Press,
} 
vulnerabilities while negotiating unrelentingly to honor her dead body in the land of God's promise. The Aqedah was a test about the covenant son (19 verses), the Cave of Macpelah is a trial of similar duration about the covenant land (20 verses). ${ }^{199}$ In the first test Abraham was taciturn, in the second he cannot be silenced. In a public court before a tribunal of the people of the land, Abraham's fear of being killed is absent and his fearless covenant-driven prophetic intercession shows he has incorporated the lesson missing from his response in the Aqedah. He has reclaimed his mantle as God's prophetleader and faithfully procures the right to invest in God's future vision for his descendants.

Sometimes the greatest learning comes after a test. With these two trials successfully passed, Abraham's covenant identity and faith has been perfected by the incorporation of all seven covenant lessons. The Aqedah was a formative test. Now the narratives of Abraham's covenant journey with God can finally come to a satisfying end.

In this section, the Covenant Hypothesis' core belief in the divine telos of Abraham, through comprehensive covenant actualization to become God's blessing to the world, carries coherent implications for direct ethical application. This provides a superior coherent moral model for understanding the Aqedah test in a relevant ethical manner. Thus, the Covenant Hypothesis fulfills Imre Lakatos' criteria of a robust progressive research paradigm. ${ }^{200}$ But since the Covenant Hypothesis is not an ethical

1991), 28-57.

${ }^{199}$ Sternberg, "Double Cave, Double Talk," 57.

${ }^{200}$ Imre Lakatos proposed that theories or research programs were networks of related beliefs that 
theory, but merely an interpretive theory, it can only point to modifications needed in Divine Command Theory and Virtue Ethics in order for them to rise to the ethical challenge of the Aqedah. More work needs to be done in this area.

\section{Aesthetics ${ }^{201}$ of Lek-lekha}

This dissertation has already demonstrated the untapped power of biblical literary aesthetics to intimate new meaning. The literary structure unearthed by the microhermeneutical level in chapter three revealed the last divine speech in the Aqedah was a systematic test answer key that referred to the covenant lessons as the test norm for evaluation. The asymmetry in the literary chiasm of Abraham's test actions in chapter four showed that prophetic intercession, the missed covenant lesson from the answer key, would have restored chiastic symmetry and aesthetic balance to Abraham's actions in the

were robustly progressive if the core beliefs generated peripheral implications that were viable and validated. If a protective belt of "ad hoc hypotheses" was continually being generated to protect the core beliefs from new applications and implications (such as God will never put another through an Aqedah-like test, or you are not Abraham and cannot do what he did, or the Torah subsequently forbids what Abraham did), the theory was to be considered regressive. Imre Lakatos, "Falsification and the Methodology of Scientific Research Programmes," Criticism and the Growth of Knowledge, eds. Imre Lakatos and Alan Musgrave (Cambridge, UK: Cambridge University Press, 1970), 91-196. See also Imre Lakatos, Proofs and Refutations (Cambridge, UK: Cambridge University Press, 1976); Nancey Murphy, A Philosophy of the Christian Religion for the Twenty-First Century (London, UK: Society for Promoting Christian Religion, 2018), 72-75; Anthony Rudd, "Reason in Ethics: MacIntyre and Kierkegaard" in Kierkegaard after MacIntyre, 141.

${ }^{201}$ Aesthetics is derived from the Greek term aisthetikos which means sensitive, sentient, related to sense perception. As a branch of philosophy, aesthetics falls under axiology for it deals with the valuation of beauty based on the senses. 
narrative. That discovery from careful aesthetic analysis also aligns all three of God's speeches in the Aqedah in ethical linear consistency. Art can birth truth.

But to cap this dissertation's axiological section, I want to reflect on the aesthetics of the unique and strikingly evocative term lek-lekha which marks the beginning and end of Abraham's covenant journey in conversation with the insights of Doukhan, Heidegger and Bollnow. In the Aqedah after Abraham answered "Here I am," Abraham's ready response was followed by the divine order to lek-lekha (walk-for/to/with-yourself). Linguistically, the verb "walk" permeates the narratives of Abraham (12:1, 4, 5, 9, 19; $13: 3,5,17 ; 14: 11,24 ; 15: 2$ [Heb]; 16:8; 17:1; 18:16, 22 33; 19:2; 21:14-16, 19, 32; 22:2$3,5-6,8,13,18) .{ }^{202}$ The most concentrated clusters are found in chapters 12 and 22 and the singular phrase lek-lekha that bookends Abraham's covenant journey is found only in those chapters. Doukhan explains that this phrase "does not just affect space, it also concerns time and the person of Abram.." ${ }^{203} \mathrm{He}$ profoundly and beautifully translates leklekha as "go in order to find yourself and thus fulfill yourself.". 204

In both chapters, God tied the divine imperative of lek-lekha to an unknown place contingent on His will: to a land that I will show you (Gen 12:1) and on one of the mountains of which I shall tell you (Gen 22:2). What kind of experience is created by

${ }^{202}$ Doukhan, Genesis, 195.

${ }^{203}$ Doukhan, Genesis, 198.

204 "In other words, the call to Abraham to 'get out' of his country and away from his roots should take him to himself- to establish his identity. It is not enough for Abram to get out of Babel; in order to find his real self, Abraham has to get rid of the Babel that is still in him, the idolatry of his fathers and the arrogant mentality of Babel.” Doukhan, Genesis, 198. 
these instructions? Abraham was called to leave a settled, safe home in each case to journey a long distance for a clear purpose — without a clear end. The end was hidden in God. Not knowing the exact location of his destination, Abraham was freed from the temporal pressure of covering distance efficiently to concentrate instead on the momentby-moment experience of walking closely with God, awaiting further instruction from above. ${ }^{205}$

Because he was set up to be acutely aware of God's abiding presence on his initial trek to Canaan, aesthetically, Abraham may have started to see the world through God's eyes. Anticipation opens the senses. Every shade of a mountain, every rushing stream or wadi, every striking vista that confronted his vision and offered itself as a possibility for stopping would make him check internally for God's promised signal to confirm it. The first lek-lekha (Gen 12) rendered Abraham hyper-attentive to what was outside and inside himself. The second lek-lekha (Gen 22) in the Abrahamic narratives started as the opposite of the first, a numbed walk toward the impending death of his son and the end of his covenant dream. But when the angel broke this tension at the top of the mountain and Abraham looked up from the knife, he saw God's ram in the bush and

\footnotetext{
205 The emotive character of this journey depends on the relationship between God and Abraham. If they were relative strangers before now, anxiety and fear would mark this event. If they had already established mutual trust, confidence and hope would accompany them.
} 
everything became right again. The walk back down the mountain gave him a new lease on life, it was the opposite of the deathwalk up Mt. Moriah.

When a person attends to their walking, this basic awareness of moving through space that is "constitutive for being-in-the-world" 206 seeps into bodily consciousness. For when humans initially encounter other objects in the world they may take for granted a sense of direction and distance but at some point, "on the basis of spatiality thus discovered, space itself becomes accessible to cognition." ${ }^{207}$ Heidegger recognized that 'the 'subject,' correctly understood ontologically, Da-sein, is spatial in a primordial sense." ${ }^{208}$ Bollnow adds "that the human being is always and necessarily conditioned in his life by his behaviour in relation to a surrounding space." ${ }^{209}$ In Kantian terms, space is definitely a "transcendental ideality" but stubbornly remains at the same time an “empirical reality." 210

For instance, when walking, the human engages in forward projection through empirical space. Forward movement lends to ethical evaluative language figurative phrases like "striving forward," referring to a general sense of progress, and "drawing

${ }^{206}$ Heidegger, Being and Time, 103.

${ }^{207}$ Heidegger, Being and Time, 103.

208 "Here, apriority means the previousness of encountering space (as region) in the actual encountering of things at hand in the surrounding world." Heidegger, Being and Time, 103.

${ }^{209}$ O. F. Bollnow, Human Space, trans. Christine Shuttleworth, ed. Joseph Kohlmaier (London: Hyphen Press, 2011), 23.

210 Bollnow, Human Space, 24. 
back," expressing reproach for not finishing a task. ${ }^{211}$ The richly evocative term journey, then, is even more significant for

the journey is not some temporary or occasional resting-place, but describes a basic situation, perhaps the basic situation of man in the world, and thus becomes one of the great primal symbols of human life, which pervades its whole interpretation to such an extent that one can hardly draw a line between its 'literal' and 'figurative' meanings. Life is perceived as a lifelong journey, and man as a traveler on this journey, a 'homo viator.' In this journey, or movement, the concepts of front and back at the same time acquire a temporal meaning: in front of us is what lies before us in the future as a stretch of life still to be traversed, while behind us is the stretch of life's journey already completed, the past. ${ }^{212}$

Abraham's intimate journey of lek-lekha with God, who bears the ultimate end of Abraham's journey in Himself also evokes overlapping notions of space. Walking covers a distance; the opposite of distance is nearness - the intimate proximity of Abraham and God and the pairing of Abraham and Isaac. Abraham's initial journey was spurred by a longing for a true homeland, ${ }^{213}$ which in humans is invariably linked with "the mysterious inward journey" for Bollnow explains, the inexpressible "longing for the distance is, in fact, a yearning for our lost origins, when life was still genuine." ${ }^{214}$ Abraham obeyed God's first command to lek-lekha to the promised land of Canaan, in which, ironically, he

${ }^{211}$ Bollnow, Human Space, 51.

${ }^{212}$ Bollnow, Human Space, 52.

${ }^{213}$ The writer of Hebrews alludes to this longing. "For people who speak thus make it clear that they are seeking a homeland. ... But as it is, they desire a better country, that is, a heavenly one. Therefore God is not ashamed to be called their God, for he has prepared for them a city." Heb 11:14, 16.

${ }^{214}$ Bollnow, Human Space, 92. 
wandered about as an alien. God's last lek-lekha brought Abraham by another journey to God's home on earth, the future temple site on a mountain in the land of Moriah.

On that dizzying sacred site, Abraham thought he had to choose between Isaac and God for space in his life. But when God's already provided ram was discovered, Abraham experienced something experientially profound about God's love. As Bollnow describes, love does not displace-love creates space, for "instead of the space clearing displacing of the 'other' from a given place and the occupation of this place by the displacer, there is the peculiar phenomenon that exactly where you are a place [for me] is created. . . . there is the peculiar phenomenon of 'limitless' increase of individual space through the surrender of individual space!" 215 High sacred spaces may initially seem restrictive and fearsome but when the worshipper surrenders their deepest fears to God's all encompassing prevenient love, they will experience the limitless horizon of expanding freedom in every direction. This is the existential promise of unbounded freedom and seeing/understanding promised to all through that ancient proverb, "On the mount of the Lord, there is vision."

\section{Conclusion}

To summarize, the macro-hermeneutics of the Axial Model deals with the philosophical or metaphysical concepts in the biblical text. At the beginning of this chapter it became apparent that the philosophical works of Kierkegaard and Derrida on the Aqedah did not rest directly on the text itself but on the unacknowledged assumption

\footnotetext{
${ }^{215}$ Bollnow, Human Space, 242.
} 
of a certain meso-hermeneutical interpretation of Abraham's test. When a new interpretive hypothesis for the Aqedah, such as the Covenant Hypothesis was substituted instead, it changed their philosophical conclusions in unexpected and intriguing ways and new concepts emerged to fill in the assumed gaps. This phenomenon demonstrates the interdependent relationship between the meso-hermeneutical level of theological interpretation and macro-hermeneutical level of philosophy and reveals the integrative and generative power of the Covenant Hypothesis on the metaphysical level.

The second section of this chapter depicted the metaphysical aspects of the Axial model. In the Axial model, the two permanent cores were the long axis of the biblical text and the punctate core of the interpreter. The core long axis of the text, on closer examination, turned out to be a filled straw: eternal transcendent deity wrapped lightly by temporal human language. In contrast to everlasting divinity, the fragile core of the interpreter was (by biblical description) dust temporally held together by divine breath, which was depicted as a dynamic network of connected knowledge nodes. The relation between the cores was then illustrated philosophically. Ontologically, a unidirectional flow of creative power and existence emanates from God to the interpreter through the biblical text. Epistemologically, because the intelligibility of any text requires the mental patterns and questions that the inquirer brings to it, the text often acts as a one-way mirror, revealing more of the interpreter back to him/her than details of God but remains reliably accurate on transmitting knowledge of both entities. Axiologically the text functions as a magnifying glass by transmitting God's values as revealed by historical 
interactions and inscribing them onto the receptive heart of a believing interpreter through the Holy Spirit.

The third section directly analyzed the worlds of meaning above and below the Aqedah text. Using the first verse of the Aqedah as an initiating step, the philosophical presuppositions regarding God and Abraham were explored systematically through ontology, epistemology and axiology.

Ontologically, the covenant journey was God's re-creation process that transformed Abram into Abraham through covenant promises and walking (lek-lekha) together. Abraham's developing covenant identity was then tested by the event of the Aqedah which exhibits all the earmarks of a historical event in the same time-space continuum of this current world. God's covenant identity as a moral Promise-Keeper was risked in the Aqedah in order to elicit from Abraham a comprehensive covenant response to the posed crisis that endangered Isaac, then fulfilled through the representative ram. Abraham's relational willingness and obedience toward God, as exemplified by his consistent reply of hinneni, enabled him to take the test, accept correction, recognize God's test solution, and pass the test in faith.

Epistemologically, the test design of the Aqedah reveals God understands human beings as historical integrative moral agents who are open to correction and revealed by phronesis. The kind of human obedience desired by God, as revealed by God's test command and final evaluation, is not the blind and simplistic compliance of an animal but of an highly intelligent and synthesizing god-like creature. God's personal reference to His own present omniscience (Now I know) in the Aqedah is dynamically supple yet 
propositionally perfect, not an admission of divine ignorance or mere anthropomorphism. Hermeneutically, Abraham's fear of powerlessness expressed by his persistent fear of being killed clarifies why he desperately clung to resurrection hope, missed the ram, and ultimately raised his knife to kill Isaac. Abraham's phobia reveals the basic universal human condition, mortals haunted by their fear of death. This also explains the stubborn longevity of traditional interpretations of the Aqedah that are driven by the human fear of death and obsessed with hierarchical power in binary paradigms.

The Axiological analysis of the Aqedah in the context of the Abraham cycle recognized the Aqedah as resembling a Divine Command challenge within a Virtue Ethics covenant journey. God's test chillingly revealed what kind of person Abraham had become due to his unresolved fear of being killed. The Covenant Hypothesis suggested that a Modified Virtue Ethics that incorporated blessing, God's telos for Abraham's covenant journey, could correct the inherent weaknesses of traditional Virtue Ethics. It also hinted that a modified Divine Command Theory that includes the whole range of covenant experience as appropriate responses to God's commands could also correspond to God's final approval and definition of Abraham's obedience. The final section reflected on the poignant phase of lek-lekha that led to a mountaintop where divine love created true freedom for Abraham by absorbing his core fear through the grace-filled solution of 
the provided ram representing God. God releases the binding of Abraham and Isaac and demonstrates "on the mount of the Lord there is vision."

In conclusion, the macro-hermeneutical study of the Aqedah demonstrates that Abraham's test as interpreted by the Covenant Hypothesis on the macro-hermeneutical level is productive for biblical philosophy and is rationally consistent with holy goodness. Alasdair Macintyre's meta-criteria for a successful theories is: “The criterion of a successful theory is that it enables us to understand its predecessors in a newly intelligible way. It, at one and the same time, enables us to understand precisely why its predecessors have to be rejected or modified and also why, without and before its illumination, past theory could have remained credible. It introduces new standards for evaluating the past. It recasts the narrative which constitutes the continuous reconstruction of the scientific tradition." ${ }^{216}$ On the macro-hermeneutical level, the Covenant Hypothesis is (1) a new interpretive hypothesis for the Aqedah that resolves many of the philosophical problems (moral conundrums, binary oppositions, aporias) arising from traditional and philosophical interpretations of the Aqedah, ${ }^{217}$ (2) its core concept of covenant actualization for impending crisis reveals morally consistent implications for praxis, ${ }^{218}(3)$

216 The Covenant Hypothesis is only a small part of the larger Judeo-Christian biblical tradition, but on the tiny scale of one interpretive theory for one biblical narrative, it coherently explains the strengths and weaknesses of rival interpretations and offers a new text-based divine assessment (vv. 15-18) that is philosophically productive for shifting hermeneutics on the Aqedah. Alasdair MacIntyre, "Epistemological Crises, Dramatic Narrative, and the Philosophy of Science," Monist 60, no. 4 (October 1977): 453-472, reprinted in Stanley Hauerwas and L. Gregory Jones, eds., Why Narrative: Readings in Narrative Theology (Grand Rapids, MI: Eerdmans, 1989), 146.

217 Thomas S. Kuhn, The Structure of Scientific Revolutions, 206.

${ }^{218}$ Imre Lakatos, "Falsification and the Methodology of Scientific Research Programmes," 91- 
is useful for evaluating the strengths and weaknesses of current philosophical approaches to the Aqedah by reclaiming the contextual paradigm of the Abrahamic covenant for rethinking Abraham's test, and (4) it recasts the narrative by offering new conceptual lenses to see it in a new and productive light.

196. 


\section{CHAPTER 6}

\section{ASSESSMENT AND RECOMMENDATIONS}

\section{Introduction}

This dissertation has produced two conceptual products: The Axial Model ${ }^{1}$ for hermeneutics and the Covenant Hypothesis ${ }^{2}$ for the Aqedah. The name of the Axial Model comes from the innovation that the text is the central long axis of the hermeneutical spiral and functions both as the source and controlling norm for the interpretive process. When this textually normative model was applied to the biblical story of the Aqedah or the Sacrifice of Isaac, the new interpretation of the Covenant Hypothesis was seen. The Covenant Hypothesis interpreted the Aqedah test as a covenant crisis challenge divinely designed to elicit a comprehensive, integrated covenant response from Abraham.

This chapter will first assess the Axial Model. Second, it will appraise the model's application to the Aqedah that resulted in the Covenant Hypothesis. Third, it will describe

\footnotetext{
${ }^{1}$ Spiral ramp, pp. 70-78; interpreter's sphere, pp. 161-167; model cores, pp. 294-301.

2 Page 224.
} 
how continued progression through the spiral ramps would work. Finally, recommendations and directions for future studies will end this chapter.

\section{Assessment of the Axial Model}

The assessment of the Axial Model will summarize the description, function, and orientation for meaning in the model then evaluate whether it satisfies the purpose of the dissertation as stated in the preface.

By description, the Axial Model is a tri-level, text-anchored, spiral model for theological hermeneutics that situates the four principles of Sola, Tota, Prima and Viva Scriptura in relation to the five biblical worlds of meaning (in, behind, in front of, above and below the text). ${ }^{3}$ The three levels are micro (textual exegesis), meso (theological), and macro (philosophical) hermeneutics which are anchored by the biblical text as the norming long axis of the spiral model. The interpreter rolls in a circular pattern on the continuous spiral ramp of the model, the ramps represent the accessible parts of the worlds of meaning for that interpreter. ${ }^{4}$

Functionally, the Axial Model integrates three circular processes of understanding. (1) Parts to a Whole-The interpreter's looping path on the ramp's surface links the parts to the whole, the text to its five worlds of meaning (in, behind, in front of, above, and below). This circuit can be a disciplined method geared toward a

\footnotetext{
${ }^{3}$ Pages $70-74$, figure 3.4 on p. 74.

${ }^{4}$ Pages 161-167, figure 4.1 on p. 163 and figure 4.2 on p. 165.
} 
theological goal. ${ }^{5}$ (2) Fusion of Horizons - Immediate synchronic understanding requires the back and forth movement of questions and answers or overlay of patterns from previous experience to make sense of the text. This engaged harmonizing fuses the horizons of the interpreter with the text's worlds of meaning. ${ }^{6}(3)$ ProjectiveIntegration—Diachronic understanding refers to projected fore-structures of understanding (micro-meso-macro hermeneutics) tested by the text then integrated into previously acquired knowledge as the interpreter spirals through the three levels of the Axial Model. ${ }^{7}$ These three circular processes characterizing three methods of understanding have been incorporated into the Axial Model.

In regard to the orientation of textual meaning, the Axial Model connects the three foci of textual interpretation (author-text-reader) but remains unabashedly theo-centric and text-anchored for worlds of actual but latent meaning that is appropriated by the competent interpreter. Ontologically, God is the central emanating source, norm, and enabler of meaning through the biblical text. ${ }^{8}$ Traversing the spiral ramps and

\footnotetext{
${ }^{5}$ Pages 164-165.

${ }^{6}$ Pages 165-166.

${ }^{7}$ Page 166.

${ }^{8}$ Pages 298-300.
} 
appropriating the findings turns meaning into transformative power that converts the core of the interpreter. ${ }^{9}$

Finally, the original purpose of this dissertation was "to respond to the works of Jon Levenson and Terrence Fretheim by applying a hermeneutical model that institutes the text of the Aqedah as the norm for a comprehensive interpretive paradigm. The goal of this model is to elucidate the test of the Aqedah and to illuminate its multiple worlds of meaning which are figuratively described as in the text, behind the text, above the text, below the text and in front of the text." ${ }^{10}$ The Axial Model has integrated the biblical text as a controlling norm for all three levels of hermeneutics and related the multiple worlds of textual meaning in a logical and schematic manner. This complex sounding model can also be described simply as a ball rolling down (or up) a Biblically anchored spiral ramp.

\section{Assessment of the Covenant Hypothesis}

When the Axial Model was applied to the Aqedah of Genesis 22, the premises for the interpretive Covenant Hypothesis were seen. How did the Axial Model help to bring about these results? The Axial Model's orientation of text-normed meaning led to a normative theocentric approach ${ }^{11}$ to interpreting the text of the Aqedah, which had been historically dominated by anthropocentric interpretations. ${ }^{12}$ The model also encouraged

\footnotetext{
${ }^{9}$ Pages 163-167, 299-301.

10 This is the Purpose Statement found in chapter one on page 9.

${ }^{11}$ Pages 178-214.

12 Pages 214-223.
} 
the integration of personal worlds of meaning as experimental patterns with the biblical worlds of meaning ${ }^{13}$ to be normed by the text. In my case, this added scientific problem solving, performance testing, comprehensive diagnosis and treatment of patients, and test design as personal resources for understanding God's test. ${ }^{14}$ Finally, the conjunctive nature of the three hermeneutical levels embraced the whole pericope, the complete canon and the metaphysical commitments of my faith community for integrating the contextual worlds of meaning surrounding the text. To demonstrate how this worked, a snippet from each hermeneutical level is reviewed below.

The micro-hermeneutical level of the Axial Model recommends repetitive analysis of the entire pericope as a method to discern authorial intention from text direction and to hear the stress points that the text places on itself. Hearing the Aqedah text speak through its own voice was critical because an overwhelming load of extrabiblical interpretations have become attached to the Aqedah through the centuries and they can drown out the subtle emphases of the Aqedah's own telling of the tale. Through careful analysis, shifts in literary structure and delineation of the linguistic details of God's last speech indicated a hidden pattern of allusions to Abraham's preceding

\footnotetext{
${ }^{13}$ Pages 171-172.

${ }^{14}$ Pages 183-192.
} 
covenant journey that appeared final, deliberate, systematic, and incomplete. ${ }^{15}$ This was a new intriguing finding.

The meso-hermeneutical level fuses personal worlds of meaning with the biblical worlds of meaning behind and in front of the text with textual norming and canonical testing. Many of the existing interpretations in Aqedah literature either ignored the biblical literary context or didn't address the last divine speech in a systematic manner. Divine testing in the biblical canon usually demanded law-abiding ethical behavior from the testee, but the Aqedah test was unique in that it demanded unethical, immoral behavior which contradicted God's previous revelations. Combining my test experiences in the sciences that were solution-oriented with performance-based tests from the field of medicine that required comprehensive ethical-pragmatic decisions in life-and-death situations, I hypothesized that the divinely provided incomplete list of evoked covenant revelations implied that God wanted to elicit an integrative problem-solving approach from Abraham in the Aqedah test. This possibility, called the Covenant Hypothesis satisfied the internal literary criteria of coherence and correspondence for the Aqedah and employed the Principles of Charity, Humanity and Occam's Razor in formulation. ${ }^{16}$ But since a "vicious" hermeneutical circle of self-fulfilling bias within the text is a real possibility for any hypothesis, the Covenant Hypothesis was tested externally by the

\footnotetext{
${ }^{15}$ Pages 145-153.

${ }^{16}$ Pages 175-176.
} 
canon using hypothetico-deductive and falsification methods. ${ }^{17}$ After passing canonical testing, the Covenant Hypothesis appeared to be a viable interpretive option.

On the macro-hermeneutical level, the Covenant Hypothesis was compared to two philosophical treatments of the Aqedah, Kierkegaard's existential work, Fear and Trembling, and Derrida's deconstructive "Literature in Secret." The Covenant Hypothesis was able to engage with their philosophical insights and generate new relationships between their concepts, even adding to their findings. ${ }^{18}$ This indicated the integrative and generative power of the theory. After the metaphysical aspects of the cores of the model was clarified, direct Aqedah-based hermeneutical philosophy was attempted through a hermeneutical philosophical methodology. What emerged from this exploration was that the Covenant Hypothesis shifted the monochromatic interpretation of the Aqedah as a test of uncomprehending literalistic obedience into a comprehensive assessment, diagnosis and treatment of Abraham's deepest beliefs and fears. ${ }^{19}$ The Covenant Hypothesis even integrated the following story (Gen 23- Cave burial purchase) to the Abrahamic cycle by

${ }^{17}$ Pages 236-256.

${ }^{18}$ Pages 272-278, 288-294.

${ }^{19}$ Pages 335-341. 
recognizing that its unusually detailed faith-driven negotiations actualized the missed covenant lesson in the Aqedah test. ${ }^{20}$

\section{Progress through the Axial Model}

What would progression through the Axial Model look like if done again? Spiraling forward in time, current metaphysical findings provide a new biblical framework of questions for a re-examination of the micro-hermeneutical details in the Aqedah. The conceptual filter changes made at the macro-hermeneutical level may bring out unrealized nuances of some linguistic details and may dampen other characteristics as less significant. Because it will be a second look at a familiar text, a wider scope of relevant meanings for terms, more intertextual allusions, or deeper immersion into relevant archeological history can now be incorporated and enhance the conceptual lens.

On the meso-hermeneutical level, the enriched conceptual lens and added microhermeneutical insights may choose to explore one of the seven other theological tasks with the expanded repertoire of perceptual patterns of meaning. Perhaps typology in relation to Sanctuary or Christology will lead the theological exploration this second time. Systematics or pastoral application can be pursued on future rounds through the model.

From the meso-hermeneutical fruits, new directions may open and the existing biblical metaphysical framework will be filled. It is expected that existing philosophical frameworks will be continually corrected by new insights from the text. On this level, the

\footnotetext{
${ }^{20}$ Pages 348-349.
} 
quality of the interpreter's questions and discrimination brought to the text is critical for fruitfulness.

To be sure, whenever an interpreter returns to a familiar text and attempts to understand it again, some of these processes will occur. What the Axial Model of hermeneutics brings to the process is systematic discipline by demarcating levels of theological complexity, self-conscious clarification of the task and methods, and reflexive insight into how transformative understanding works. The Axial model is a historically conscious realist approach that is naturally self-critical by accepting the long axis of Scripture as both the basis and norm for every hermeneutical level.

\section{Recommendations}

The Axial Model can be improved and adjusted. Two immediate needs come to mind. They are (1) to incorporate more fully the trinitarian nature of God into the model and (2) to extend the model's applicability to the preaching function. The challenge of the first task is how to depict Jesus as God who fills the inside of the straw-like long axis but at the same time embodies the Word of God. Is there a way to trace how the Holy Spirit aids in the looping path of the interpreter's sphere and aids appropriation and transformation beyond what readers experience through engaging in secular literature?

The second task might envision the interpreter/preacher fusing their horizons with the congregation's horizons as conjoined spiritual allies spiraling together by encountering the text and the biblical worlds of meaning on the same spiral model. The current models of a congregation linked to the pastor/theologian but not connected directly to the biblical text leaves room for improvement. But since the listener or another 
interpreter carries their own personal worlds of meaning and will differ in accessibility to the worlds of meaning, how can two spheres on different ramps truly understand each other? This is the critical challenge of hermeneutical consensus.

Many other questions have not been covered in this study. These questions could be addressed on future rounds of the Axial Model. How does God speak to Abraham? How do divine words re-create human beings (Abram-Abraham)? What is the science of hermeneutical understanding that changes humans? Why does God utilize promises, questions, commands and testing, instead of comprehensive explanations (as theologians do) to develop mature believers? How does action and performance affect the understanding of the agent? Through the Aqedah, what other hermeneutical insights has God uncovered about the universal human condition? What might Isaac have learned about God, Abraham, and himself had Abraham responded perfectly to the test according to all the covenant lessons and what did Isaac learn from this actual experience? Is there any indication that God wanted Sarah along on this test, and if so, why would He? Was Abraham's secrecy about the test command the right choice or was this test meant to be a communal test as the first command was? Does the fact that the whole community was circumcised mean they were to participate in the Aqedah? What sociological ripples did the Aqedah tradition have? Did it scar the psyche of the faith community? Moses, who had requested a three-day journey for sacrifices, was repeatedly accused by the liberated 
Israelites of bringing them to the wilderness to kill them-was this an aftereffect of the Aqedah?

In conclusion, the Covenant Hypothesis happens to be one first fruit of the Axial Model of hermeneutics as applied to the Aqedah. It shows that the Axial Model as a comprehensive, integrative, and text-based hermeneutical model fulfills the original purpose of this study. Yet only God, who is depicted as the center of the Axial Model, can lead the inquiring interpreter to the full and final truth, to Himself. To that blessed hope, I submit these dissertation products as tentative helps to hear God's Word better. 


\section{CITED BIBLIOGRAPHY}

Adams, Robert Merrihew. Finite and Infinite Goods: A Framework for Ethics. New York, NY: Oxford University Press, 1999.

Aejmelaeus, Anneli. "Function and Interpretation of כי in Biblical Hebrew." Journal of Biblical Literature 105, no. 2 (1986): 193-209.

Alexander, T. Desmond. "Genesis 22 and the Covenant of Circumcism." JSOT 8, no. 25 (Feb 1983): 17-22.

Alter, Robert. "Biblical Imperatives and Literary Play." In "Not in Heaven": Coherence and Complexity in Biblical Narrative, edited by Jr. Jason P. Rosenblatt and Joseph G. Sitterson. Bloomington, IN: Indiana University Press, 1991.

—. Genesis: Translation and Commentary. New York, NY: W. W. Norton, 1996.

-. "How Convention Helps Us Read: The Case of the Bible's Annunciation TypeScene." Prooftexts 3, no. 2 (May 1983): 115-130.

—. The Art of Biblical Narrative. New York, NY: Basic Books, 1981.

Andersen, Francis I. The Sentence in Biblical Hebrew. Hague, NL: Mouton Publishers, 1974.

Aristotle. Poetics. Accessed 9 December 2019. http://data.perseus.org/citations/urn:cts:greekLit:tlg0086.tlg034.perseuseng1:1450b ction\%3D1450b.

Athanassoulis, Nafsika. "Virtue Ethics." The Internet Encyclopedia of Philosophy. n.d. Accessed 2 April 2019. https://www.iep.utm.edu/virtue/.

Auerbach, Erich. Mimesis: The Representation of Reality in Western LIterature. Princeton, NJ: Princeton University Press, 1953.

Augustine. Sermons (1-19) on the Old Testament. Translated by Edmund Hill. Vol. 1. 3 vols. Hyde Park, NY: New City Press, 1990. 
Austin, John Langshaw. How to Do Things with Words. Cambridge, MA: Harvard University Press, 1975.

Aylesworth, Gary. "Postmodernism." The Stanford Encyclopedia of Philosophy. Spring 2015. Accessed 5 June 2019. https://plato.stanford.edu/archives/spr2015/entries/postmodernism/.

Bahktin, Mikhail. Problems of Dostoevsky's Poetics. Vol. 8, Theory and History of Literature. Translated by Caryl Emerson. Minneapolis, MN: University of Minnesota Press, 1984.

Baker, Christopher R. Entering the New Theological Space: Blurred Encounters of Faith. Burlington, VT: Ashgate, 2013.

Balserak, Jon. "Luther, Calvin and Musculus on Abraham's Trial: Exegetical History and the Transformation of Genesis 22." Reformation and Renaissance Review 6, no. 3 (2004): 361-373.

Bar-Efrat, Shimon. Narrative Art in the Bible. New York, NY: T\&T Clark, 2008.

—. "Some Observations on the Analysis of Structure in Biblical Narrative." Vetus Testamentum 30, no. 2 (1980): 154-173.

Barr, James. The Semantics of Biblical Language. Eugene, OR: Wipf \& Stock, 2004.

Barth, Karl. Church Dogmatics. Vol. 1. Translated by Geoffrey W. Bromiley and G.T. Thomson and Harold Knight. New York, NY: T\&T Clark, 2010.

Barthes, Roland. "From Work to Text." In Textual Strategies: Perspectives in PostStructuralist Criticism, edited by Josue V. Harari, 73-81. Ithaca, NY: Cornell University Press, 1979.

Bartholomew, Craig G. Introducing Biblical Hermeneutics: A Comprehensive Framework for Hearing God in Scripture. Grand Rapids, MI: Baker Academic, 2015.

—, and Michael W. Goheen. Christian Philosophy: A Systematic and Narrative Introduction. Grand Rapids, MI: Baker Academic, 2013.

Beardsley, Monroe C. Aesthetics: Problems in the Philosophy of Criticism. 2nd ed. Indianapolis, IN: Hackett Publishing, 1981.

Bellack, Alan S., and R. L. Morrison, eds. Medical Factors and Psychological Disorders: A Handbook for Psychologists. New York, NY: Plenum Press, 1987. 
Bem, Daryl J., and Andrea Allen. "On Predicting Some of the People Some of the Time: The Search for Cross-Sectional Consistencies in Behavior." Psychological Review 81, no. 6 (1974): 506-520.

Berman, Louis A. The Aqedah: The Binding of Isaac. Northvale, NJ: Jason Aronson, 1997.

Bernasconi, Robert. "Supplement." In Jacques Derrida: Key Concepts, edited by Claire Colebrook, 18-22. London, UK: Routledge, 2015.

Berry, John. "What Makes Us Human? Augustine on Interiority, Exteriority, and the Self." Scientia et Fides 5, no. 2 (2007): 87-106.

Bloom, B. S., J. T. Hastings, and G. F. Madaus. Handbook on Formative and Summative Evaluation of Student Learning. New York, NY: McGrall-Hill, 1971.

Blumenthal, David. "John Levenson, The Death and Resurrection of the Beloved Son." Revue des eudes juives 160, no. 1-2 (January 2001): 265-268.

Bodoff, Lippman. "God Tests Abraham, Abraham Tests God." Bible Review 9, no. 5 (October 1993).

-. The Binding of Isaac, Religious Murders and Kabbalah: Seeds of Jewish Extremism and Alienation? Jerusalem, IL: Devora Publishing Company, 2005.

Boehm, Omri. The Binding of Isaac: A Religious Model of Disobedience. New York, NY: T\&T Clark, 2007.

Bollnow, O. F. Crisis and New Beginning: Contributions to a Pedagogical Anthropology. Translated by Donald Moss and Nancy Moss. Pittsburgh, PA: Duquesne University Press, 1987.

-. Human Space. Edited by Joseph Kohlmaier. Translated by Christine Shuttleworth. London, UK: Hyphen Press, 2011.

Borgman, Paul. Genesis: The Story We Haven't Heard. Downer's Grove, IL: InterVarsity Press, 2001.

Bove, Laurence. "Unbinding the Other: Levinas, the Akedah, and going beyond the Subject." In Interpreting Abraham: Journeys to Moriah, edited by Matthew T. Powell Bradley Beach, 169-186. Minneapolis, MN: Fortress Press, 2014.

Brettler, Adele Berlin and Marc Zvi, ed. The Jewish Study Bible: Jewish Society Tanakh Translation. Oxford, UK: Oxford University Press, 2004. 
Brogan, Walter A. Heidegger and Aristotle: The Twofoldness of Being. Albany, NY: State University of New York Press, 2005.

Brown, Francis, S. R. Driver, Charles A. Briggs, James Strong, Wilhelm Genesius. The Brown-Driver-Briggs Hebrew and English Lexicon: With an Appendix Containing the Hebrew Aramaic. Peabody, MA: Hendrickson Publishers, 1996.

Brown, William. "Psalms and Hebrew Poetry." In Cambridge Companion to the Hebrew/Old Testament, 253-273. Cambridge, UK: Cambridge University Press, 2016.

Brueggemann, Walter. "Genesis." In The New Interpreter's Bible, edited by Michael E. Lawrence. Nashville, TN: Abingdon Press, 1994.

-. Genesis, Interpretation: A Bible Commentary for Teaching and Preaching. Louisville, KY: Westminster John Knox Press, 2010.

Buber, Martin. I and Thou. Translated by Ronald Gregor Smith. New York, NY: Continuum, 2004.

-. On the Bible. Edited by Nahum N. Glatzer. Translated by Harold Bloom. New York, NY: Schocken, 1968.

Burks, Arthur W. "Pierce's Theory of Abduction." Philosophy of Science 13, no. 4 (October 1946): 301-306.

Butler, Tom. "Towards a Hermeneutic Model for Interpretive Research in Information Systems." Journal of Information Technology 13, no. 4 (1998): 285-300.

Cahoone, Lawrence. From Modernism to Postmodernism. Malden, MA: Blackwell Publishing Ltd, 2003.

Calaprice, Alice. The New Quotable Einstein. Princeton, NJ: Princeton University Press, 2005.

Calvin, John. Commentaries on the First Book of Moses Called Genesis. Vol.1. Translated by John King. Grand Rapids, MI: Eerdmans, 1948.

-. The Calvin Handbook. Edited by Herman J. Selderhuis. Grand Rapids, MI: Eerdmans, 2009.

Canale, Fernando. "A Biblical Epistemology for Adventist Scholarship." Paper presentation, Fourth Symposium on the Bible and Adventist Scholarship, General 
Conference of Seventh-day Adventists. Riviera Maya, Estado Quintana Roo, Mexico, 2008.

—. "A Criticism of Theological Reason: Time and Timelessness as Primordial Presuppositions." In Andrews University Seminary Doctoral Dissertation Series. Berrien Springs, MI: Andrew University Press, 1987.

—. "Deconstructing Evangelical Theology?" Andrews University Seminary Studies 44, no. 1 (2006): 95-130.

—. "Evolution, Theology and Method, Part 3: Evolution and Adventist Theology." Andrews University Seminary Studies 42, no. 1 (2003): 165-184.

—. "Paradigm, System, and Theological Pluralism." The Evangelical Quarterly 70, no. 3 (1998): 195-218.

Caputo, John. Deconstruction in a Nutshell: A Conversation with Jacques Derrida. New York, NY: Forham University Press, 1997.

-. The Prayers and Tears of Jacques Derrida: Religion without Religion. Bloomington, IN: Indiana University Press, 1997.

Carasik, Michael. "The Limits of Omniscience." JBL 119, no. 2 (2000): 221-232.

Carmody, Timothy R. Reading the Bible: A Study Guide. Mahwah, NJ: Paulist Press, 2004.

Cassirer, Ernst. An Essay on Man: An Introduction to a Philosophy of Human Culture. New Haven, CT: Yale University Press, 1944.

Cauley, Kathleen M. and James H. McMillan. "Formative Assessment Techniques to Support Student Motivation and Achievement." The Clearing House: A Journal of Educational Strategies, Issues and Ideas 83, no. 1 (July 2010): 1-6.

Cawthorne, Nigel. Alexander the Great. London, UK: Haus Publishing Limited, 2004.

Chalamet, Christophe. Dialectical Theologians: Wilhelm Herrmann, Karl Barth and Rudolf Bultmann. Zürich, CH: Theologischer Verlag Zürich, 2005.

Chladenius, Johann Martin. "Introduction to the Correct Interpretation of Reasonable Discourses and Writings." In The Hermeneutics Reader, edited by Kurth MuellerVollmer, 54-71. New York, NY: Continuum, 1990. 
Cibangu, Sylvain K. "Karl Popper and the Social Sciences." In Social Sciences and Cultural Studies, by Asuncion Lopez-Varela. IntechOpen, n.d.

Coats, George W. "Abraham's Sacrifice of Faith: A Form-Critical Study of Genesis 22." Union Seminary Review 27, no. 4 (October 1973): 389-400.

Collins, Allan M. "A Spreading-Acitvation Theory of Semantic Processing." Psychological Review 82, no. 4 (1975): 407-428.

Collins, Jack. "A Syntactical Note (Genesis 3:15): Is the Woman's Seed Singular or Plural?" Tyndale Bulletin 48, no. 1 (1997): 139-148.

Colman, Andrew M. Oxford Dictionary of Psychology. Oxford, UK: Oxford University Press, 2015.

Comstock, Gary L. "Two Types of Narrative Theology." Journal of the American Academy of Religion 55, no. 4 (Winter 1987): 687-717.

Congdon, David W. The Mission of Demythologizing: Rudolf Bultmann's Dialectical Theology. Minneapolis, MN: Fortress Press, 2015.

Corley, Bruce, Steve W. Lemke, Grant I. Lovejoy, eds. Biblical Hermeneutics: A Comprehensive Introduction to Interpreting Scripture. Nashville, TN: Broadman and Holman Publishers, 2002.

Cottingham, John, Robert Stoothoff, Dugald Murdoch, eds. The Philosophical Writings of Descartes. Cambridge, UK: Cambridge University Press, 1984.

Crenshaw, James. A Whirlpool of Torment. Philadelphia, PA: Fortress Press, 1984.

Crow, N. Clayton. Prima Scriptura: An Introduction to New Testament Interpretation. Grand Rapids, MI: Baker Academic, 2011.

Curkpatrick, Stephen. "Authority of the Text: The Hermeneutical Question." Colloquim 33, no. 2 (2001): 135-152.

Dahlstrom, Daniel O. "Hermeneutic Ontology." In Theory and Applications of Ontology: Philosophical Perspectives, edited by R. Poli and J. Sebt, 395-415. New York, NY: Springer, 2010.

Dalby, J. Thomas. "Dr. Albert Ellis and Rational-Emotive Therapy." Alberta Psychology 6, no. 3 (May/June 1987): 16-18, 22. 
Davenport, John J. Towards an Existential Virtue Ethics: Kierkegaard and MacIntyre. Edited by Anthony Rudd John J. Davenport. Chicago, IL: Open Court, 2001.

Davidson, Donald. Inquiries into Truth and Interpretation. Oxford, UK: Oxford University Press, 1984.

—. Problems of Rationality. Oxford, UK: Oxford University Press, 2004.

Davidson, Jo Ann. "Abraham, Akedah and Atonement." In Creation, Life, and Hope: Essays in Honor of Jacques Doukhan, edited by Jiri Moskala, 49-72. Berrien Springs, MI: Old Testament Department, Seventh-day Adventist Theological Seminary, Andrews University, 2000.

Davidson, Robert. The Courage to Doubt: Exploring an Old Testament Theme. Eugene, OR: Wipf \& Stock, 1983.

Davies, Philip R., and Bruce D. Chilton. "The Aqedah: A Revised Tradition History." The Catholic Biblical Quarterly 40, no. 4 (1978): 514-546.

Dawkins, Richard. The God Delusion. Boston, MA: Houghton Mifflin, 2006.

Delaney, Carol. Abraham on Trial. Princeton, NJ: Princeton University Press, 1998.

Dennett, Daniel. The Intentional Stance. Cambridge, MA: MIT Press, 1987.

Dementyev, Vadim. "For the Sake of Beauty: Proposing a Homiletic of Trinitarian Performance." PhD dissertation, Fuller Theological Seminary, 2019.

Derrida, Jacques. The Gift of Death and Literature in Secret. Translated by David Wills. Chicago, IL: University of Chicago Press, 2008.

Dewey, John. Human Nature and Conduct. New York, NY: Henry Holt and Company, 1922.

Doukhan, Jacques. Hebrew for Theologians: A Textbook for the Study of Biblical Hebrew in Relation to Hebrew Thinking. Lanham, MD: University Press of America, 1993.

-. Seventh-day Adventist International Bible Commentary: Genesis. Mountain View, CA: Pacific Press Publishing Association, 2016.

-. "The Aqedah at the Crossroads: Its Significance in the Jewish-Christian-Muslim Dialogue." Andrews University Seminary Studies 32, no. 1-2 (1994): 20-40. 
—. "The Center of the Aqedah: A Study of the Literary Structure of Genesis 22:1-19." Andrews University Seminary Studies, no. 1 (Spring 1993): 17-28.

Dreyfus, H., and C. Spinosa. "Further Reflections on Heidegger, Technology and the Everyday." In Philosophical Romanticism, 339-349. New York, NY: Routledge, 2006.

DSM-5 Guidebook: The Essential Companion to the Diagnostic and Statistical Manual. Washington, D. C. : American Psychiatric Publishing, 2014.

Dworkin, Ronald. Law's Empire. Cambridge, CT: Harvard University Press, 1986.

Efird, David. "Divine Command Theory and the Semantics of Quantified Model Logic." In New Waves in Philosophy and Religion, edited by Yujin Nagasawa and Erik J. Wielenberg, 91-104. Basingstoke, UK: Palgrave Macmillan, 2009.

Einstein, Albert. "On the Method of Theoretical Physics." Philosophy of Science 1, no. 2 (April 1934): 163-169.

Ellis, E. Earle. The Old Testament in Early Christianity: Canon and Interpretation in the Light of Modern Research. Translated by Wissenschaftliche Untersuchungen Zum Neuen Testament. Tübingen, GE: J.C.B. Mohr, 1991.

Elwell, Walter A. Evangelical Dictionary of Theology. Grand Rapids, MI: Baker Book House, 2001.

Fabry, G. Johannes Botterweck, Helmer Ringgren, and Heinz-Josef, eds. Theological Dictionary of the Old Testament. Vol. IV. Grand Rapids, MI: Eerdmans, 1998.

Fackre, Gabriel. "Narrative Theology: An Overview." Interpretation 37, no. 4 (1983): 340-352.

Feldman, Yael S. Glory and Agony: Isaac's Sacrifice and National Narrative. Stanford, CA: Stanford University Press, 2010.

Fitzgerald, Allan D., ed. Augustine Through the Ages. Grand Rapids, MI: Eerdmans, 1999.

Fitzmyer, Joseph A. The Biblical Commission's Document "The Interpretation of the Bible in the Church": Text and Commentary. Rome: Editrice Pontificio Istituto Biblico, 1995.

Fokkelman, J. P. Narrative Art in Genesis: Specimens of Stylistic and Structural Analysis. Eugene, OR: Wipf \& Stock, 1991. 
-. Reading Biblical Narrative: An Introductory Guide. Louisville, KY: Westminster Knox Press, 1999.

Føllesdal, Dagfinn. "Hermeneutics and the Hypothetico-Deductive Method." Dialectica 33, no. 3-4 (1979): 319-336.

Fowler, Robert M. Let the Reader Understand: Reader-Response Criticism and the Gospel of Mark. New York, NY: Bloomsbury Academic, 1991.

Fretheim, Terence. Abraham: Trials of Family and Faith. Columbia, SC: University of South Carolina, 2007.

-. Creation Untamed: The Bible, God and Natural Disasters. Grand Rapids, MI: Baker Academic, 2010.

-. God and the World in the Old Testament: A Relational Theology of Creation. Nashville, TN: Abingdon Publishing, 2005.

—. "God, Abraham and the Abuse of Isaac." Word and World 15, no. 1 (1995).

-. The Suffering of God: An Old Testament Perspective. In Overtures to Biblical Theology. Philadelphia, PA: Fortress Press, 1984.

Friedman, Maurice, ed. The Worlds of Existentialism: A Critical Reader. New York, NY: Random House, 1964.

Fuchs, Ernst. "The Hermeneutical Problem." In The Future of our Religious Past, Essays in Honour of Rudolf Bultmann, edited by J. M. Robinson, 267-278. London, UK: SCM Press, 1971.

Gadamer, Hans Georg. "On the Circle of Understanding." In Hermeneutics Versus Science? Three German Views, edited by J. M. Connolly and T. Keutner, 68-78. South Bend, IN: University of Notre Dame, 1988.

—. "On the Circle of Understanding." In Hermeneutics Versus Science? Three German Views, edited by J. M. Connolly and T. Keutner. South Bend, IN: University of Notre Dame Press, 1988.

—. "The Historicity of Understanding." In The Hermeneutics Reader, 256-292. New York, NY: Continuum, 1990.

—. Truth and Method. New York, NY: Continuum, 1989. 
Gellman, Jerome. Abraham! Abraham! Kierkegaard and the Hasidim on the Binding of Isaac. Burlington, VT: Ashgate Publishing, 2003.

Genette, Gerard. Narrative Discourse: An Essay on Method. Ithaca, NY: Cornell University Press, 1972.

Gesenius, Wilheim. Gesenius' Hebrew Grammar. Edited by E. Kautzsch. Translated by A. E. Cowley. Mineola, NY: Dover Publications, 2006.

Girard, Rene. Violence and the Sacred. New York, NY: Continuum, 2005.

Gordon, C. H. "Build-up and Climax." In Studies in Bible and Ancient Near East Presented to Samuel E. Lowenstamm, edited by Y. Blau Y. Avishur, 29-34. Jerusalem, ISR: E. Rubinstein's Publishing House, 1978.

Green, Joel B., ed. Dictionary of Scripture and Ethics. Grand Rapids, MI: Baker Academic, 2011.

Griffin, David Ray. Sacred Interconnections: Postmodern Spirituality, Political Economy, and Art. Albany, NY: State University of New York Press, 1990.

Groisman, Berry. "What is Dialectic? Some Remarks on Popper's Criticism." Semantic Scholar. 2007. Accessed 4 April 2019. https://pdfs.semanticscholar.org/2b75/ee47d375e370524acca827bc9beb561793b1 .pdf?_ga=2.157851834.1649370957.1565621990-1013515737.1562578160.

Grondin, Jean. "Gadamer's Basic Understanding of Understanding." In The Cambridge Companion to Gadamer, edited by R. Dostal, 36-51. Cambridge, UK: Cambridge University Press, 2002.

-. "What is the Hermeneutical Circle?" In The Blackwell Companion to Hermeneutics, 299-305. Malden, MA: Blackwell, 2016.

Guba, Egon G., and Yvonna S. Lincoln. "Competing Paradigms in Qualitative Research." In Handbook of Qualitative Research, edited by N. K. Denzin and Y. S. Lincoln, 105-119. Thousand Oaks, CA: Sage, 1994.

Guthrie, W. K. C. A History of Greek Philosophy, Volume 6: Aristotle: An Encounter. Cambridge, UK: Cambridge University Press, 1981.

Haleem, Abdel, trans. The Qur'an: English Translation with Parallel Arabic Text. Oxford: Oxford University Press, 2010. 
Halliday, Macmillian A. K. Linguistic Studies of Text and Discourse. Edited by Jonathan Webster. New York, NY: Continuum, 2002.

Hamilton, Victor. The Book of Genesis, Chapters 18-50. Grand Rapids, MI: Eerdmans, 1995.

Hanna, Martin. "Foreknowledge and the Freedom of Salvation." In Salvation: Contours of Adventist Soteriology, 33-59. Berrien Springs, MI: Andrews University Press, 2018.

Harmon, Jerry. "Exodus 34:6-7: A Hermeneutical Key in the Open Theism Debate." In PhD dissertation, Mid-America Baptist Theological Seminary. 2006.

Hegel, Georg Wilhelm Friedrich. Early Theological Writings. Translated by T. M. Knox. Chicago, IL: University of Chicago Press, 1948.

Heidegger, Martin. Being and Time. Albany, NY: State University of New York Press, 1996.

—. "Letter on Humanism." In Basic Writings, edited by D. F. Krell, 213-165. London, UK: Routledge, 1978.

Hempel, Carl G. "Studies in the Logic of Confirmation (II.)." Mind 54, no. 214 (April 1945): 97-121.

Hennig, Boris. "What is Formal Ontology?" In Applied Ontology: An Introduction, edited by Katherine Munn and Barry Smith, 39-56. Heusenstam, BRD: Ontos Verlag, 2008.

Heschel, Abraham. God in Search of Man. New York, NY: Farrar, Straus and Giroux, 1983.

—. Man is Not Alone: A Philosophy of Religion. New York, NY: The Noonday Press, 1979.

Hirsch, E. D., Jr. Validity in Interpretation. New Haven, CT: Yale University Press, 1967.

Hirsch, Emil. "Jephthah (יפתח) in Jewish Encyclopedia." JewishEncyclopedia.com. 2011. Accessed 17 April 2019. http://www.jewishencyclopedia.com/articles/8584jephthah.

Hitchens, Christopher. God is Not Great: How Religion Poisons Everything. New York, NY: Hachette Book Group, 2007. 
Hofman, Marina. "Dream Type-Scene in Old Testament Narratives: Structure and Significance." PhD diss., University of St. Michael's College, 2014.

Hoozer, Kevin J. Van, Craig G. Bartholomew and Daniel J. Treier. Dictionary for Theological Interpretation. Grand Rapids, MI: Baker Book House, 2005.

Horobin, Wendy, ed. How It Works: Science and Technology. $3^{\text {rd }}$ ed. Tarrytown, NY: Marshall Cavendish, 2003.

Hutcheon, Linda. "Incredulity toward Metanarrative: Negotiating Postmodernism and Feminisms." In Collaboration in the Feminine: Writings on Women and Culture from Tessera, edited by Barbara Godard, 186-192. Toronto, CN: Second Story Press, 1994.

Jacobsen, Thorkild. "The Graven Image." In Ancient Isrealite Religion: Essays in Honor of Frank Moore Cross, edited by Patrick D. Miller Jr., S. Dean McBride, and Paul D. Hanson, 15-32. Philadelphia, PA: Fortress, 1987.

James, R. C. Mathematics Dictionary. $5^{\text {th }}$ ed. New York, NY: Chapman and Hall, 1992.

Jaspers, Karl. Truth and Symbol. Translated by William Kluback, William Kimmel, Jean T. Wilde. New York, NY: NCUP, 1956.

Kaiser, Walter C. Jr., and Moisés Silva. Introduction to Biblical Hermeneutics. Grand Rapids, MI: Zondervan, 2007.

-, Peter H. Davids, F. F. Bruce, Manfred T. Brauch, eds. Hard Sayings of the Bible. Downers Grove, IL: InterVarsity Press, 1996.

Kalimi, Isaac. "Go, I Beg You, Take Your Beloved Son and Slay Him!: Binding of Isaac in Rabbinic Literature and Thought." Review of Rabbinic Judaism 13 (2010): 129.

Kant, Immanuel. Groundwork of the Metaphysics of Morals. Translated and edited by Mary Gregor. In Cambridge Texts in the History of Philosophy. Cambridge, UK: Cambridge University Press, 1998.

-. Religion within the Limits of Reason Alone. Translated by H. H Hudson and T. M. Greene. New York, NY: Harper, 1960.

Kärkkäinen, William A. Dyrness and Veli-Matti, eds. Global Dictionary of Theology. Downers Grove, IL: InterVarsity Press, 2008.

Kierkegaard, Soren. Fear and Trembling. London: Penguin Group, 1985. 
King, Henry T., Jr. "The Legacy of Nuremburg." Case Western Journal of International Law 34, no. 335 (Fall 2002).

Kintsch, Walter and Teun A. van Dijk. "Toward a Model of Text Comprehension and Production." Psychological Review 55, no. 5 (Sept 1978): 363-394.

Kintsch, Walter. "The Role of Knowledge in Discourse Comprehension: A ConstructionIntegration Model." Psychological Review 95, no. 2 (1988): 163-182.

Klemm, David. "General Introduction." In Hermeneutical Inquiry: The Interpretation of Texts, edited by Scholars Press, 23-32. Atlanta, GA, 1986.

—. The Hermeneutical Theory of Paul Ricoeur. Lewisburg, PA: Bucknell Press, 1983.

Kort, Wesley A. Story, Text and Scripture: Literary Interests in Biblical Narrative. University Park, PA: Pennsylvania State University Press, 1988.

Koskela, Jani. "Discontinuity as Foundation to Pedagogy." PhD dissertation. University of Oulu, Oulu, Finland. 2012.

Krashkevich, David, and Susan R. Loehr. "Ophthalmic Glasses." In The Properties of Optical Glass, 263-270. New York, NY: Springer, 1998.

Kreuzer, Seigfried. "Das Opfer des Vaters—die Gefährdung des Sohnes: Genesis 22." Amt und Gemeinde 37 (July/August 1986): 62-70.

Kuhn, Thomas S. The Structure of Scientific Revolutions. 3rd ed. Chicago, IL: University of Chicago Press, 1996.

Küng, Hans. Theology for the Third Millenium. Translated by Peter Heinegg. New York, NY: Doubleday, 1988.

Kuypers, Jim A., ed. Rhetorical Criticism. New York, NY: Rowman and Littlefield, 2009.

LaFollette, Hugh, and Ingmar Persson, eds. The Blackwell Guide to Ethical Theory. Malden, MA: Wiley-Blackwell, 2013.

Lagerkvist, Amanda. "Existential Media: Toward a Theorization of Digital Throwness." New Media and Society 19, no. 1 (2017): 96-110.

Lakatos, Imre. "Falsification and the Methodology of Scientific Research Programmes." In Criticism and the Growth of Knowledge, edited by Imre Lakatos and Alan Musgrave, 91-196. Cambridge, UK: Cambridge University Press, 1970. 
-. Proofs and Refutations. Cambridge, UK: Cambridge University Press, 1976.

Landy, Fancis. "Narrative Techniques and Symbolic Transactions in the Akedah." In Signs and Wonders: Biblical Texts in Literary Focus, edited by J. Cheryl Exum. The Society of Biblical Literature Semeia Studies, 1-40. Atlanta, GA: The Society of Biblical Literature, 1989.

Leena Kakkori and Rauno Huttunen. "Aristotle and Pedagogical Ethics." Paideusis 16, no. 1 (2007): 17-28.

Leitch, Vincent B. American Literary Criticism since the 1930's. New York, NY: Routledge, 2010.

Lett, James. "Emics and Etics: Notes on the Epistemology of Anthropology." In Emics and Ethics: The Insider/Outsider Debate, edited by Kenneth L. Pike, Marvin Harris, and Thomas N Headland, 127-142. Newbury Park, CA: Sage, 1990.

Levenson, Jon. "Abusing Abraham: Traditions, Religious Histories, and Modern Misinterpretations." Judaism 43, no. 3 (Summer 1998): 259-277.

—. "Curriculum Vitae." Harvard Divinity School. July 2013. Accessed 2 January 2017. http://hds.harvard.edu/files/hds/files/c.v._levenson_8-16-15_web.pdf.

-. Resurrection and the Restoration of Israel: The Ultimate Victory of the God of Israel. New Haven, CT: Yale University Press, 2006.

-. The Death and Resurrection of the Beloved Son: The Transformation of Child Sacrifice in Judaism and Christianity. New Haven, CT: Yale University Press, 1993.

-. The Hebrew Bible, the Old Testament, and Historical Criticism. Louisville, KY: Westminster John Knox Press, 1993.

Levy, Ze'ev. "On the Aqedah in Modern Philosophy." Journal of Jewish Thought and Philosophy, 2007: 85-105.

Licht, Jacob. Storytelling in the Bible. Jerusalem, IL: Magnes Press, 1986.

Lipton, Peter. Inference to the Best Explanation. New York, NY: Routledge, 1991.

Lisa Iverach, Ross G. Menzies, Rachel E. Menzies. "Death Anxiety and its Role in Psychopathology: Reviewing the Status of a Transdiagnostic Construct." Clinical Psychology Review 34, no. 7 (November 2014): 580-593. 
Lombaard, Christo. The Old Testament and Christian Spirituality: Theoretical and Practical Essays from a South African Perspective. Atlanta, GA: Society of Biblical Literature, 2012.

Lonergan, Bernard. Method In Theology. Toronto, CN: University of Toronto Press, 1971.

Lundbom, Jack R. Bible Rhetoric and Rhetorical Criticism. Sheffield, UK: Sheffield Phoenix Press, 2013.

Luther, Martin. Luther's Works. American Edition. 55 vols. Edited by Jaroslav Pelikan and Helmut T. Lehmann. Philadelphia, PA: Muehlenberg and Fortress, and St. Louis, MO: Concordia, 1955-1986.

Lyotard, Jean-François. "The Postmodern Condition: A Report on Knowledge." In $A$ Postmodern Reader, edited by Linad Hutcheon and Joseph P. Natoli, 71-90. Albany, NY: State University of New York Press, 1993.

MacIntyre, Alasdair. A Short History of Ethics. New York, NY: The Macmillan Company, 1966.

—. "Epistemological Crisis, Dramatic Narrative, and the Philosophy of Science." In Why Narrative: Readings in Narrative Theology, edited by Stanley Hauerwas and L. Gregory Jones. Grand Rapids, MI: Eerdmans, 1989.

MacIntyre, Jane L. "Personal Identity and the Passions." Journal of the History of Philosophy 27, no. 4 (Oct 1989): 545-557.

Maier, Gerhard. Biblical Hermeneutics. Wheaton, IL: Crossway Books, 1994.

Manis, R. Zachary. "Kierkegaard and Evans on the Problem of Abraham." Journal of Religious Ethics 39, no. 3 (2011): 474-492.

Mantzavinos, Chrysostomos. Naturalistic Hermeneutics. Translated by Darrell Arnold. Cambridge, UK: Cambridge University Press, 2005.

Margolis, Howard. Paradigms and Barriers: How Habits of Mind Govern Scientific Beliefs. Chicago, IL: University of Chicago Press, 1993.

-. Patterns, Thinking and Cognition: A Theory of Judgment. Chicago, IL: University of Chicago Press, 1987.

Mayer, John D. and Peter Salovey. "The Intelligence of Emotional Intelligence." Intelligence 17 (1993): 433-442. 
McGuirk, James. "Heidegger's Reading of Aristotle's Ethics: Re-appropriations, Transformations and the Spectre of Kierkegaard." Academia.edu. n.d. Accessed 3 March 2019.

https://www.academia.edu/36233148/Heideggers_reading_of_Aristotles_Ethics_r e-appropriations_transformations_and_the_spectre_of_Kierkegaard.

McKnight, Edgar V. Post-Modern Use of the Bible: The Emergence of Reader-Oriented Criticism. Nashville, TN: Abingdon Press, 1990.

Metzger, James A. Consumption and Wealth in Luke's Travel Narrative. Translated by Biblical Interpretation Series. Leiden, Boston: Brill, 2007.

Middleton, Richard. "Unbinding the Aqedah from the Straightjacket of Tradition: An Inner-Biblical Interpretation of Abraham's Test in Genesis 22." In upcoming book, Lament Rekindled, ed. Matthew Anstey, Jeanette Matthews, and Peter Lockwood. First presented (under the title "How Abraham Lost his Son") as the Zenas Gerig Memorial Lecture at Jamaica Theological Seminary at Kingston, Jamaica, September 2012.

Milgrom, Jo. "The Binding of Isaac, the Akedah: A Primary Symbol of Jewish Thought and Art." In Doctoral Dissertations of Graduate Theological Union, edited by Duane L. Christensen. Berkeley, CA: BIBAL Press, 1988.

Milgrom, Stanley. Obedience to Authority: An Experimental View. New York, NY: Harper Perennial, 2009.

Miller, Christian. "Divine Desire Theory and Obligation." In New Waves in Philosophy and Religion, edited by Yujin Nagasawa and Erik J. Wielenberg, 105-124. Basingstoke, UK: Palgrave Macmillan, 2009.

Moberly, R. W. L. "Book Review of Levenson, Jon D. The Death and Resurrection of the Beloved Son: The Transformation of Child Sacrifice in Judaism and Christianity." The Journal of Religion 75, no. 2 (April 1995): 262-263.

-. The Bible, Theology and Faith: A Study of Abraham and Jesus. Cambridge, UK: Cambridge University Press, 2000.

—. "The Earliest Commentary on the Akedah." Vetus Testamentum 38, no. 3 (July 1988): 302-333.

Mooney, Edward F. "Abraham and Dilemma: Kierkegaard's Theological Suspension of the Ethical Revisited." International Journal for the Philosophy of Religion 19, no. 2 (1986): 23-41. 
Moreland, J. P., and William Lane Craig. Philosophical Foundations for a Christian Worldview. Downers Grove, IL: InterVarsity Press, 2003.

Moynihan, Robert. A Recent Imagining: Interviews with Harold Bloom, Geoffrey Hartman, J. Hillis MIller, Paul De Man. Hamden, CT: Archon Books, 1986.

Mueller, Ilse. "Celebration and Narration. Metaleptic Features in Ex 12:1-13, 16." In Narratology, Hermeneutics and Midrash: Jewish, Christian and Muslim Narratives from Late Antiquity through Modern Times, 25-37. Göttingen, AU: Vienna University Press, 2014.

Muilenburg, James. "Form Criticism and Beyond." Journal of Biblical Literature 88, no. 1 (March 1969): 1-18.

Mundt, C. "Jaspers Concept of 'Limit Situation': Extensions and Therapeutic Applications." In Karl Jasper's Philosophy and Psychopathology, edited by Thiemo Breyer, Christoph Mundt Thomas Fuchs, 169-178. New York, NY: Springer, 2014.

Murphy, Nancey. A Philosophy of the Christian Religion for the Twenty-First Century. London, UK: Society for Promoting Christian Religion, 2018.

Murray, J. A. H., ed. The Compact Ediction of the Oxford English Dictionary. Oxford, UK: Oxford University Press, 1979.

Nagao, Teruhiko. "On Authorial Intention: E. D. Hirsch's Validity in Interpretation Revisited." The Annual Reports on Cultural Science 40, no. 1 (November 1991): 161-180.

Neusner, Jacob. Genesis Rabbah. Vol. 2. Lanham, MD: University Press of America, 2001.

Niiniluoto, Illkka, and Raimo Toumela. Theoretical Concepts and Hypothetico-Inductive Inference. Dordrecht, Holland: D. Reidel Publishing Company, 1973.

Olafsson, Gudmundur. "The Use of NS in the Pentateuch and its Significance for the Biblical Understanding of Forgiveness." PhD Dissertation, Andrews University, 1993.

Osborne, Grant R. The Hermeneutical Spiral: A Comprehensive Introduction to Biblical Interpretation. Downers Grove, IL: InterVarsity Press, 2006. 
Oswalt, John N. "Abraham's Experience of Yahweh: an Argument for the Historicity of the Patriarchal Narratives." In Perspectives on Our Father Abraham: Essays in Honor of Marvin R. Wilson, 33-43. Grand Rapids, MI: Eerdmans, 2010.

Otto, Eckart. "A Hidden Truth Behind the Text or the Truth of the Text." In South African Perspectives on the Pentateuch between Synchrony and Diachrony, edited by Jurie H. le Roux and Eckart Otto, 19-28. New York, NY: Clark, 2007.

Palmer, Elizabeth. Faith in the Hidden God: Luther, Kierkegaard and the Binding. Minneapolis, MN: Fortress Press, 2017.

Palmquist, Stephen R., and Philip McPherson Rudisill. "Three Perspectives on Abraham's Defense against Kant's Charge of Immoral Conduct." The Journal of Religion 89, no. 4 (October 2009): 467-497.

Pannenberg, Wolfhart. "God of the Philosophers." First Things. June 2007. Accessed 4 March 2019. https://www.firstthings.com/article/2007/06/002-god-of-thephilosophers.

Peckham, John C. Canonical Theology: The Biblical Canon. Sola Scriptura, and Theological Method. Grand Rapids, MI: Eerdmans, 2016.

Petterson, Staffan Carlshamre and Anders, ed. Types of Interpretation in the Aesthetic Disciplines. Ithaca, NY: McGill University Press, 2003.

Pierce, C. S. Collected Papers of Charles Sanders Pierce. Edited by Charles Hartshone and Paul Weiss. Cambridge, MA: Harvard University Press, 1974.

Plato. Phaedrus. Translated by James H. Nichols jr. Ithaca, NY: Cornell University Press, 1998.

Plaut, G., ed. The Torah: A Modern Commentary. New York, NY: UAHC Press, 1981.

Polanyi, Michael. "Problem Solving." British Journal for the Philosophy of Science 8, no. 30 (August 1957): 89-103.

Popper, Karl. The Logic of Scientific Discovery. New York, NY: Routledge, 2002.

—. "What is Dialectic?" In Conjectures and Refutations, 419-451. London, UK: Routledge and Kegan Paul, 2002.

Porten, Bazalel. "The Root Pair ישב in Jeremiah." In Hamlet on a Hill: Semitic and Greek STudies Presented to Professor T. Muraoka on the Occasion of His Sixty- 
Fifth Birthday, edited by M. F. J. Baasten W. Th. Van Peursen, 375-382. Leuven, BY: Peeters Publishers and Department of Oriental Studies, 2003.

Quine, W. V. O. Word and Object. Cambridge, CT: M. I. T. Press, 1960.

Quinn, Phillip. "Agamemnon and Abraham: The Tragic Dilemma of Kierkegaard's Knight of Faith." Journal of Literature and Theology 4, no. 2 (July 1990): 181193.

Rad, Gerhard Von. Genesis: A Commentary. Philadelphia, PA: Westminster Press, 1972.

Reid, George W., ed. Understanding Scripture: An Adventist Approach. Hagerstown, MD: Review and Herald Publishing Association, 2005.

Reif, S. C. "A Root to Look Up: A Study of the Hebrew nasa', 'ayin." Vetus Testamentum Supplements 36 (1985): 230-244.

Rendsburg, Gary A. "Variation in Biblical Hebrew Prose and Poetry." In Built by Wisdom, Established by Understanding: Essays on Biblical and Near Eastern Literature in Honor of Adele Berlin, edited by Maxine L. Grossman, 197-226. Bethesda, MD: University Press of Maryland, 2013.

Rennie, David. "Qualitative Research as Methodical Hermeneutics." Psychological Methods 17, no. 3 (2012): 385-398.

Richard, Ramesh P. "Methodological Proposals for Scripture Relevance, Part 2: Levels of Biblical Meaning." Bibliotheca Sacra 143, no. 570 (April 1986): 123-133.

Ricoeur, Paul. Figuring the Sacred: Religion, Narrative, and Imagination. Edited by Mark Wallace. Translated by David Pellauer. Minneapolis, MN: Fortress Press, 1995.

- Hermeneutics and the Human Sciences: Essays on Action, Language and Interpretation. Edited by John B. Thompson. Cambridge, UK: Cambridge University Press, 1998.

-. Memory, History, Forgetting. Translated by Kathleen Blamey and David Pellauer. Chicago, IL: University of Chicago Press, 2006.

-. Oneself As Another. Translated by Kathleen Blamey. Chicago, IL: University of Chicago Press, 1994.

—. "The Concept of Fallibility." In Contemporary European Ethics: Selected Readings, edited by Joseph J. Kockelmans. New York, NY: Doubleday \& Company, 1972. 
-. "The Model of the Text: Meaningful Action Considered as a Text." New Literary History 5, no. 1 (August 1973): 91-117.

-. The Symbolism of Evil. Translated by Emerson Buchanan. Boston, MA: Beacon Press, 1967.

-. Time and Narrative. Translated by Kathleen McLaughlin and Davi Pellauer. 3 vols. Chicago, IL: University of Chicago Press, 1984.

Robinson, J. C. "s.v. "Existential Hermeneutics"." In Dictionary of Biblical Criticism and Interpretation, edited by Stanley E. Porter, 105-106. New York, NY: Routledge, 2007.

Rosemond v. United States. 12-895 (SCOTUS, Mar 5, 2014).

Rosenberg, Joel. "Meanings, Morals, and Mysteries: Literary Approaches to the Torah." Response 9, no. 2 (Summer 1975): 67-94.

Roshwalb, Esther H. "Build-up and Climax in Jeremiah's Visions and Laments." In Boundaries of the Ancient Near Eastern World: A Tribute to Cyrus H. Gordon, edited by Claire Gottlieb, Sharon Keller Mier Lubetski, 111-135. Sheffield, UK: Sheffied Academic Press, 1998.

Rudd, Anthony. "Reason in Ethics: MacIntyre and Kierkegaard." In Kierkegaard after MacIntyre, edited by John J. Davenport and Anthony Rudd, 131-150. Chicago and LaSalle, IL: Open Court, 2001.

Rudd, John J. Davenport and Anthony, ed. Kierkegaard After MacIntyre. Chicago, IL: Open Court, 2001.

Sailhammer, John. The Meaning of the Pentateuch: Revelation, Composition, and Interpretation. Downers Grove, IL: IVP Academic, 2009.

Sankey, Howard. "Scientific Method." In The Routledge Companion to Philosophy of Science, edited by Martin Curd and Stathis Psillos, 280-290. London, UK: Routledge, 2014.

Santogrossi, Ansgar. "Scotus' Method in Ethics: Not to play God--A Reply to Thomas Shannon." Theological Studies 55 (1994): 314-329.

Sarna, Nahum. JPS Torah Commentary: Genesis, The Traditional Hebrew Text with the new JPS Translation. New York, NY: The Jewish Publication Society, 1989. 
Sartre, Jean-Paul. Existentialism Is a Humanism. Edited by John Kulka. Translated by Carol Macomber. New Haven, CT: Yale University Press, 2007.

Scheler, Max. On the Eternal in Man. Translated by Bernard Noble. New York, NY: Harper and Brothers, 1960.

Schiralli, Martin. Constructive Postmodernism: Toward Renewal in Cultural and Literary Studies. Westport, CT, 1999.

Schleiermacher, Friedrich D. E. "Compendium of 1819." In The Hermeneutics Reader, 72-97. New York, NY: Continuum, 1990.

-. Schleiermacher: Hermeneutics and Criticism and Other Writings. Edited by Andrew Bowie. Translated by Cambridge Texts in the History of Philosophy. Cambridge, UK: Cambridge University Press, 1998.

Schmid, K. "Abraham's Sacrifice: Gerhard von Rad's Interpretation of Gen 22." Interpretation 62, no. 3 (2008): 268-276.

Schwartz, George. Encyclopedia of Knowledge Management. Hershey, PA: Idea Group Reference, 2006.

Seters, J. Van. Abraham in History and Tradition. New Haven, CT: Yale University Press, 1975.

Shapiro, Gary and Alan Sica. Hermeneutics: Questions and Prospects. Amherst, MA: University of Massachusetts Press, 1984.

Sharp, Carolyn J. Irony and Meaning in the Hebrew Bible. Bloomington, IN: Indiana University Press, 2009.

Sherwood, Yvonne. "Binding-Unbinding: Divided Responses of Judaism, Christianity, and Islam to the 'Sacrifice' of Abraham's Beloved Son." Journal of the American Academy of Religion 72, no. 4 (2004): 821-861.

Speiser, E. A. Genesis. Translated by Anchor Bible Series. Vol. 1. Garden City, NY: Doubleday \& Company, 1964.

Spiegel, Shalom. The Last Trial. Translated by Judah Goldin. New York, NY: Pantheon Books, 1967.

Spinoza, Benedictus de. Theological-Political Treatise. Translated by Samuel Shirley. Indianapolis, IN: Hackett Publishing, 2001. 
Sternberg, Meir. "Double Cave, Double Talk: The Indirections of Biblical Dialogue." In Not in Heaven, edited by Jason P. Rosenblatt and Joseph C. Sitterson Jr., 28-57. Indianapolis, IN: Indiana University Press, 1991.

—. The Poetics of Biblical Narrative. Bloomington, IN: Indiana University Press, 1985.

Stewart, David, and Algus Mickunas. Exploring Phenomenology: A Guide to the Field and Its Literature. Athens, OH: Ohio University Press, 1990.

Stiltner, Brian. "Who Can Understand Abraham? The Relation of God and Morality in Kierkegaard and Aquinas." Journal of Religious Ethics 21, no. 2 (1993): 221-245.

Stolorow, Robert D. "Heidegger, Mood and the Lived Body: The Ontical and the Ontological." Janus Head: Journal of Interdisciplinary Studies in Literature, Continential Philosophy, Phenomenological Psychology, and the Arts 13, no. 2 (2014): 5-11.

Strasser, Stephan. Understanding and Explanation: Basic Ideas Concerning the Humanity of the Human Sciences. Pittsburgh, PA: Duquesne University Press, 1985.

Studebaker, Steven M. "The Mode of Divine Knowledge in Reformation Arminianism and Open Theism." JETS 47, no. 3 (September 2004): 469-480.

Taghinejad, M., A. Ghasemi, A. Kubiri, M. Imani. "Ricoeur's Theory of Interpretation: A Method of Understanding Text." World Applied Sciences Journal 15, no. 11 (2011): 1623-1629.

Taras, Madelina. "Assessment: Summative and Formative: Some Theoretical Reflections." British Journal of Educational Studies 53, no. 4 (Dec 2005): 466478 .

Taylor, Charles. "Interpretation and the Sciences of Man." The Review of Metaphysics 25, no. 1 (September 1971): 3-51.

Thiselton, Anthony. New Horizons in Hermeneutics: The Theory and Practice of Transforming Biblical Reading. Grand Rapids, MI: Zondervan, 1992.

- Thiselton on Hermeneutics: The Collected Works and New Essays of Anthony Thiselton. In the series Ashgate Contemporary Thinkers on Religion: Collected Works, general editor, John R. Hinnells. Burlington, VT: Ashgate Publishing, 2006. 
Tillich, Paul. "What is wrong with 'Dialectic' Theology?" The Journal of Religion XV, no. 2 (April 1935): 127-145.

Todorov, Tzvetan. The Poetics of Prose. Translated by Richard Howard. New York, NY: Cornell University Press, 1977.

Trible, Phyllis. "Genesis 22: The Sacrifice of Sarah." In "Not in Heaven": Coherence and Complexity in Biblical Narrative, edited by J. Rosenblatt and J. Sitterson, 170191. Bloomington, IN: Indiana University Press, 1991.

Vanhoozer, Kevin. Is there Meaning in this Text? The Bible, the Reader, and the Morality of Literary Knowledge. Grand Rapids, MI: Zondervan, 1998.

Ven, Johannes Van der. Ecclesiology in Context. Grand Rapids, MI: Eerdmans, 1996.

Wacome, Karen Ann Halvorsen. "Watching the Sacrifice of Isaac: Bahktin, Dialogism and Genesis 22:1-19." PhD dissertation, Graduate Theological Union, 2005.

Wall, John, William Schweiker and W. David Hall, eds. Paul Ricoeur and Contemporary Moral Thought. New York, NY: Routledge, 2002.

Wallace, Mark. The Second Naiveté: Barth, Ricoeur, and the New Yale Theology. Vol. 6, Studies in American Biblical Hermeneutics. Macon, GA: Mercer University Press, 1990.

Walsh, Carey Ellen. "Christian Theological Interpretations of God's Grace in the Binding of Isaac." Perichoresis 10, no. 1 (2012): 41-66.

Ward, Keith. "The God of the Philosophers and the God of Abraham, Isaac, and Jacob." The Journal of Jewish Thought and Philosophy 8, no. 2 (Jan 1999): 157-170.

Wenham, Gordon. Genesis 16-50. Waco, TX: Word, 1995.

Westermann, Claus. Genesis 12-36: A Commentary. Minneapolis, MN: Augsburg Fortress, 1985.

Westphal, Merold. Kierkegaard's Concept of Faith. Grand Rapids, MI: Eerdmans, 2014.

White, Ellen G. The Story of Patriarchs and Prophets. Vol. 1. Conflict of the Ages. Mountain View, CA: Pacific Press Publishing Association, 1958.

Wimsatt, W. K., Monroe C. Beardsley. "The Intentional Fallacy." In The Verbal Icon: Studies in the Meaning of Poetry, 3-18. Lexington, KY: University of Kentucky Press, 1954. 
Wintermute, O. S. "Jubilees: A New Translation and Introduction." In The Old Testament Pseudepigrapha, by J. H. Charlesworth, 35-41. New York, NY: Doubleday, 1985.

Wittgenstein, Ludwig. On Certainty. Oxford: Blackwell, 1969.

-. Philosophical Investigations. Translated by G. E. M. Anscombe. Oxford: Basil Blackwell, 1986.

Wolters, Albert M. "On the Idea of Worldview and its Relation to Philosophy." In Stained Glass: Worldviews and Social Science, 14-25. Lanham, MD: University Press of America, 1989.

Yandell, Keith E. "Religious Experience and Rational Appraisal." Religious Studies 10 (May 1974): 173-187.

Young, Amos. "Divine Omniscience and Future Contingents: Weighing the Presuppositional Issues in the Contemporary Debate." ERT 26, no. 3 (2002): 240264.

Zagzebski, Linda. Divine Motivational Theory. New York, NY: Cambridge University Press, 2004.

Zimra, Rabbi Yossi ben. "Sanhedrin 89b." In Bablyonian Talmud. n.d.

Zondervan Illustrated Dictionary. Grand Rapids, MI: Zondervan, 2001. 